\title{
Consequences of dry period length and dietary energy source on physiological health variables in dairy cows and calves
}

Novi Mayasari

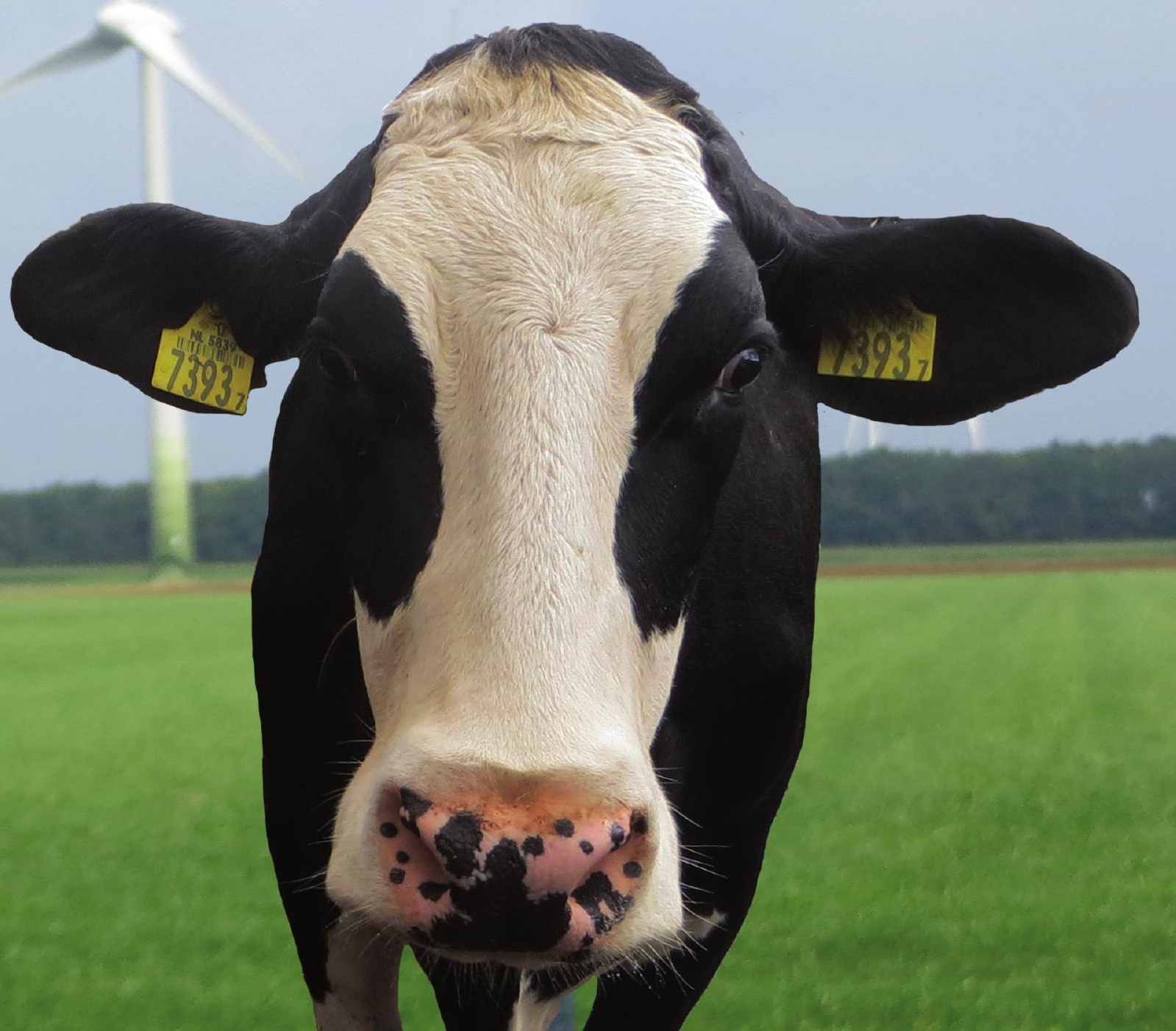


Consequences of dry period length and dietary energy source on

\author{
physiological health variables \\ in dairy cows and calves
}

Novi Mayasari 


\section{Thesis committee}

\section{Promotor}

Prof. Dr B. Kemp

Professor of Adaptation Physiology

Wageningen University \& Research

\section{Co-promotors}

Dr A.T.M. van Knegsel

Senior Researcher, Adaptation Physiology Group

Wageningen University \& Research

Dr H.K. Parmentier

Assistant Professor, Adaptation Physiology Group

Wageningen University \& Research

\section{Other members}

Prof. Dr H.F.J. Savelkoul, Wageningen University \& Research, the Netherlands Prof. Dr U. Bernabucci, Università degli Studi della Tuscia-Viterbo, Italy

Prof. Dr T.J.G.M. Lam, Utrecht University, the Netherlands

Dr H.M. Hammon, Leibniz Institute for Farm Animal Biology, Germany

This research was conducted under the auspices of the Graduate School of Wageningen Institute of Animal Sciences (WIAS) 


\title{
Consequences of dry period length and dietary energy source on physiological health variables in dairy cows and calves
}

\author{
Novi Mayasari
}

Thesis

submitted in fulfilment of the requirements for the degree of doctor at Wageningen University

by the authority of the Rector Magnificus,

Prof. Dr A.P.J. Mol,

in the presence of the

Thesis Committee appointed by the Academic Board

to be defended in public

on Wednesday $24^{\text {th }}$ of May 2017

at 11 a.m. in the Aula. 
Novi Mayasari

Consequences of dry period length and dietary energy source on physiological health variables in dairy cows and calves

222 pages.

$\mathrm{PhD}$ thesis, Wageningen University, Wageningen, the Netherlands (2017)

With references, with summary in English

ISBN: 978-94-6343-140-8

DOI: $10.18174 / 409860$ 


\begin{abstract}
During the transition period, dairy cows experience a negative energy balance (NEB) caused by the high energy requirement for milk yield, while feed intake is limited. Severity of the NEB has been associated with an increased incidence of metabolic disorders and infectious diseases, inflammation, immunosuppression and oxidative stress. It is known that shortening or omitting the dry period or feeding a glucogenic ration improves the energy balance (EB) in dairy cows in early lactation. It can be expected that an improvement of the EB due to shortening or omitting the dry period results in reduced inflammation, immunosuppression and less oxidative stress in dairy cows in early lactation. The first objective of this thesis was to study the effects of dry period length and dietary energy source on immune competence, inflammatory biomarkers and oxidative stress in dairy cows over 2 subsequent lactations. The second objective was to study the consequences of maternal dry period length on colostrum immunoglobulin content and immune competence of calves in the first 12 weeks of life. In the current study, 167 cows were assigned to 3 dry period lengths $(0,30$, or $60 \mathrm{~d})$ and 2 early lactation rations (glucogenic or lipogenic). Cows were planned to have the same dry period length and ration over 2 subsequent lactations. Omitting the dry period reduced plasma bilirubin levels compared with a conventional dry period, which is line with the better EB in cows with a 0-d dry period. Effects of dry period length on inflammatory biomarkers, oxidative stress variables and natural antibodies (NAb) titers were, however, less consistent. Omitting the dry period increased not only negative acute phase proteins (APP) in plasma, but also positive APP, oxidative stress variables in plasma, and NAb in milk. Shortening the dry period to $30-\mathrm{d}$ did not influence inflammatory biomarkers and oxidative stress compared with a conventional dry period of $60-\mathrm{d}$. Occurrence of clinical health problems did not differ between cows with different dry period lengths. In the current study, changes in positive APP and oxidative stress variables in plasma and NAb in milk could be explained by the occurrence of clinical health problems related to inflammation (clinical mastitis, fever, metritis and retained placenta), rather than a better EB due to a shorter or no dry period. Moreover, a higher titer of $\mathrm{IgG}$ binding lipopolysaccharide in plasma was associated with decreased odds of high somatic cell count and occurrence of clinical mastitis. In the first lactation after implementation of dry period length and dietary treatments, feeding a glucogenic ration in early lactation increased NAb titers in milk compared with a lipogenic ration, which could be explained partly by a better EB. In the second lactation after
\end{abstract}


implementation of dry period length and dietary treatments, feeding a lipogenic ration in early lactation increased cholesterol levels in plasma compared with a glucogenic ration, which could be related to the high fat content in this ration. Cows with a 0-d dry period had a lower colostrum production and less immunoglobulins in colostrum compared with cows with a 30-d or 60-d dry period. After colostrum uptake, NAb titers in plasma of calves from cows with a 0-d dry period were lower during the first week of life compared with calves from cows with a 30-d or 60-d dry period. Levels of specific antibodies in calves, after immunization in week 6 and 10, in calves were not affected by the maternal dry period length. Birth weight of calves from cows with a 0-d dry period was lower compared with calves from cows with a 30-d dry period, but not compared with calves from cows with a 60-d dry period. Growth of calves until 12 weeks of life was not affected by dry period length. In conclusion, although shortening and omitting the dry period improved the EB in early lactation, this did not result in clear consistent effects of dry period length on inflammation or oxidative stress. Changes in inflammation biomarkers, oxidative stress variables and NAb in milk were a reflection of the occurrence of health problems related to inflammation in particular clinical mastitis and compromised uterine health. Furthermore, albeit omitting the dry period compared with shortening or conventional dry period cows resulted in a reduced immunoglobulin content in colostrum and reduced NAb titers in plasma of their calves in the first week of life, but did not affect specific immune response of the calves in the first 12 weeks of life. 


\section{Table of contents}

Chapter 1 General introduction 9

Chapter 2 Effects of dry period length and dietary energy source on 37 inflammatory biomarkers and oxidative stress in dairy cows

Chapter 3 Relationships between inflammatory biomarkers and oxidative stress with uterine health in dairy cows with different dry period lengths

Chapter 4 The effects of dry period length and dietary energy source on natural antibody titers and mammary health in dairy cows

Chapter 5 Effect of maternal dry period length on colostrum immunoglobulin content and natural and specific antibody titers in calves

Chapter 6 Natural autoantibodies in Bos taurus calves during the first twelve weeks of life

Chapter 7 General discussion

Summary

List of abbreviation

Acknowledgement

About the author

Curriculum vitae

Overview of scientific publications

Training and supervision plan 



\section{CHAPTER 1}

General introduction 


\subsection{Achievements of the Dairy Industry}

In the past decades, continuous progress in genetic selection, diet regimes and technology increased milk production of dairy cows. In the past 20 years, total milk production in the world increased by more than 60 percent (Figure 1.1). Based on FAOstat database (2016), main milk producing countries in the world are India, The United States of America (USA), The Russian Federation, Germany, and Pakistan. The USA, Germany and India were responsible for more than 50 percent of milk production in the world in 2013. Moreover, the Netherlands produced 2 percent of the milk produced by dairy cows in the world in 2013. The average size of dairy herds has continuously increased over recent decades in selected developed countries, where New Zealand has the highest average number of cows per herd (from 200 till 400 cows per herd) when compared to the USA (75 till 150 cows per herd) and Germany (25 till 50 cows per herd) from 1996 till 2014 (Barkema et al., 2015).

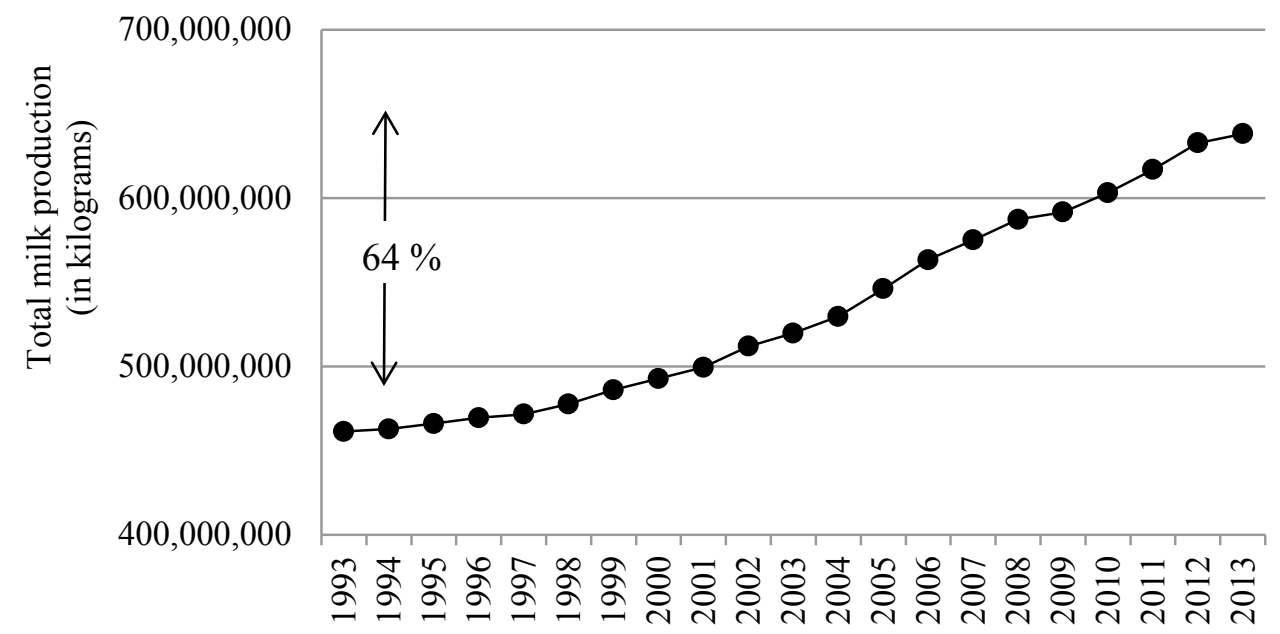

Figure 1.1 Total of milk production from cows in the world over the past 20 years (FAOstat, 2016)

\subsection{Health of High-Producing Dairy Cows}

High milk production in dairy cows is associated with increased health problems especially during the transition period (Heuer et al., 1999, Fleischer et al., 2001, Walsh et al., 2011). The transition period in dairy cows is defined as 3 
weeks before to 3 weeks after calving (Grummer, 1995, Drackley, 1999) and is considered as a critical time in the lactation cycle of a dairy cow. Most health problems occur during this period. The main health problems in dairy cows are mastitis, lameness and reduced fertility. The prevalence of these 3 major health problems is particularly high during the transition period (Collard et al., 2000, Koeck et al., 2012). Mastitis is an inflammation of the udder and one of the most costly health problems in dairy industry amounting about €61 - €97 per cow on a farm annually (Hogeveen et al., 2011). The risk for clinical mastitis increases with age, and severity of negative energy balance (NEB) in early lactation (Leslie et al., 2000) and is associated with a reduced productive life time (Carlén et al., 2004). Lameness represent group of foot and leg problems resulting in poor performance and welfare problems (Whay et al., 1997). Cows with lameness had decreased milk yield (Green et al., 2002, Amory et al., 2008), decreased fertility (Garbarino et al., 2004) and reduced productive life time (Booth et al., 2004). Reduced fertility in high-producing dairy cows is related to reproduction problems like metritis and cystic ovarian disease and manifests by a longer interval from calving until first ovulation and first oestrus, lower conception rates and higher frequency of abnormal oestrus cycles, resulting in an increased calving interval and replacement rate (Lucy et al., 2001, Opsomer et al., 2000, Beam and Butler, 1999).

Mastitis, lameness and reduced fertility in dairy cows are not only related to the start of lactation, but also to metabolic stress related to the high metabolic priority for lactation and the inability of the cow to adapt effectively to the new lactation (Van Knegsel et al., 2014). Failure to adapt to a new lactation is related with the severity of NEB and can result in metabolic and digestive disorders like milk fever, ketosis, fatty liver and left displaced abomasum (Grummer, 1993, Rajala-Schultz et al., 1999). Prevalence of clinical mastitis, lameness, reproductive problems, and ketosis varies widely between studies (Table 1.1). The prevalence of clinical mastitis ranged from 10.1 to 23.0 percent in the first 4 weeks after calving (LeBlanc et al., 2002, Zwald et al., 2004, Santschi et al., 2011). The prevalence of lameness in dairy cows ranged from 3.1 to 12.2 percent in the first 4 weeks after calving (LeBlanc et al., 2002, Zwald et al., 2004). Prevalence of reproduction problems including cystic ovaries, metritis, and retained placenta in dairy cows in the first 4 weeks after calving ranged from 3.0 
to 60.4 percent (LeBlanc et al., 2002, Zwald et al., 2004, Santschi et al., 2011). The prevalence of clinical endometritis ranged from 15 to 20 percent in the first 4 weeks after calving (LeBlanc et al., 2002, Sheldon et al., 2009). Ketosis prevalence in dairy cows in the first 4 weeks after calving ranges between 3.1 90.3 percent (LeBlanc et al., 2002, Watters et al., 2008, Santschi et al., 2011).

Low fertility and health problems affect performance and culling rates in dairy cows and are the main reason for a short productive life time (Beaudeau et al., 1995). It can be hypothesized that a reduction in the prevalence of health problems in early lactation e.g. by improving adaptation to a new lactation and improving the EB in early lactation, increases productive life time in dairy cows. Earlier, metabolism and energy balance (EB) in early lactation have been related with productive life time of dairy cows (Seifi et al., 2011, Roberts et al., 2012, Chiumia et al., 2013). Both a high body condition score at last service in heifers (Chiumia et al., 2013) and an elevated plasma free fatty acid (FFA) concentration in early lactation (Seifi et al., 2011) were associated with an increased risk of early culling. A retrospective study showed an elevated FFA and $\beta$ hydroxybutyrate (BHB) concentrations in plasma and reduced plasma calcium concentrations in early lactation were associated with an increased risk of culling (Roberts et al., 2012).

\subsection{Negative Energy Balance During the Transition Period}

A NEB in high yielding dairy cows in early lactation is a result of high energy requirement for maintenance and milk production that is not compensated by a sufficient energy intake. Consequently, dairy cows mobilize body fat and to a lesser extend body protein to support energy requirements for maintenance and milk production (Grummer, 1995). The NEB already starts 3 weeks before calving due to high nutrient requirements of the fetus (Bell, 1995), the decreased feed intake during late gestation, and the onset of lacto-genesis in this period (Grummer, 1995). The NEB is most severe during the first weeks after calving, when milk production is high and feed intake is still limited. High producing dairy cows experience a dramatic increase in energy requirements which reaches the peaks between 4 and 8 weeks after calving (Grummer, 1995, Hammon et al., 2009). 


\subsection{Metabolic Disorders and Infectious Diseases during the Transition Period}

Dairy cows experience substantial metabolic and physiological adaptations during the transition from pregnancy to lactation. Metabolic changes during the transition period are characterized by increased FFA and BHB concentrations in plasma (Drackley et al, 2001, Gross et al., 2011) which are related with extensive body fat mobilisation and fatty acid oxidation (Wathes et al., 2007a). In early lactation, the hepatic uptake of FFA exceeds the capacity of the liver to oxidize FFA or to export them from the liver as very low density lipoprotein (VLDL). This results in accumulation of tri-acyl-glycerides (TAG) in the liver and elevated ketone body concentrations in plasma (Drackley, 1999). High hepatic TAG and high ketone bodies in plasma can result in a fatty liver and ketosis (Veenhuizen et al., 1991, Grummer, 1995). Moreover, cows that experience a severe NEB during transition period show dramatic changes in circulating hormones such as progesterone, estrogen, cortisol, insulin and insulin like growth factor-I (IGF-I) (Goff and Horst, 1997). At the onset of lactation, cows with a severe NEB have decreased plasma glucose, insulin and IGF-I concentrations to support elevated endogenous glucose production and transport of glucose and FFA to the mammary gland (Hammon et al., 2009, Gross et al., 2011). As a result, FFA concentration in plasma is increased and cows are more susceptible to ketosis and fatty liver in early lactation (Grummer, 1993). Additionally, low insulin and glucose concentrations in plasma enhance lipolysis in adipose tissue, which is related to reduce responsiveness of the ovaries to gonadotropin stimulation (Butler and Smith, 1989). Another consequence of the high metabolic rate and milk production in early lactation is an increase in mineral requirements such as calcium and magnesium. If the requirements of calcium and magnesium are not met, this results in cows that suffer from clinical hypocalcaemia (milk fever) and hypomagnesaemia (Mulligan and Doherty, 2008). 
Table 1.1 Prevalence of health problems during lactation in dairy cows.

\begin{tabular}{|c|c|c|c|c|}
\hline Study & Health problem & $\begin{array}{c}\text { Time (from } \\
\text { calving } \\
\text { to ..) }\end{array}$ & $\begin{array}{l}\text { Frequency } \\
\text { (percent) }\end{array}$ & $\begin{array}{l}\text { Number } \\
\text { of cows in } \\
\text { the study } \\
\text { (N) }\end{array}$ \\
\hline \multirow[t]{6}{*}{ Koeck et al. (2012) ${ }^{1}$} & Mastitis & $305 \mathrm{~d}$ & 12.5 & 54801 \\
\hline & Lameness & $305 \mathrm{~d}$ & 9.0 & 32172 \\
\hline & Retained placenta & $305 \mathrm{~d}$ & 4.5 & 75154 \\
\hline & Metritis & $150 \mathrm{~d}$ & 10.8 & 53327 \\
\hline & Cystic ovaries & $150 \mathrm{~d}$ & 8.6 & 41144 \\
\hline & Ketosis & $100 \mathrm{~d}$ & 4.4 & 24237 \\
\hline \multirow{3}{*}{$\begin{array}{l}\text { Collard } \\
(2000)^{2}\end{array} \quad$ et al. } & Mastitis & $100 \mathrm{~d}$ & 35.0 & 140 \\
\hline & Laminitis & $100 \mathrm{~d}$ & 25.7 & 140 \\
\hline & $\begin{array}{l}\text { Reproductive } \\
\text { problems (metritis, } \\
\text { cystic ovaries, } \\
\text { uterus infection, } \\
\text { retained placenta, } \\
\text { and vaginitis) }\end{array}$ & $100 \mathrm{~d}$ & 16.4 & 140 \\
\hline \multirow{5}{*}{${ }_{1,2}^{\text {Zwald et al. (2004) }}$} & Mastitis & $28 \mathrm{~d}$ & 23.4 & 105029 \\
\hline & Lameness & $28 \mathrm{~d}$ & 12.2 & 50611 \\
\hline & Cystic ovaries & $28 \mathrm{~d}$ & 2.8 & 65080 \\
\hline & Metritis & $28 \mathrm{~d}$ & 60.4 & 97316 \\
\hline & Ketosis & $28 \mathrm{~d}$ & 90.3 & 52898 \\
\hline \multirow{6}{*}{$\begin{array}{l}\text { LeBlanc } \\
(2002)^{1,2}\end{array}$ et al. } & Mastitis & $30 \mathrm{~d}$ & 10.1 & 21 \\
\hline & Lameness & $30 \mathrm{~d}$ & 3.1 & 21 \\
\hline & Retained placenta & $30 \mathrm{~d}$ & 14.4 & 21 \\
\hline & Metritis & $30 \mathrm{~d}$ & 3.0 & 21 \\
\hline & Endometritis & $30 \mathrm{~d}$ & 14.0 & 21 \\
\hline & Ketosis & $30 \mathrm{~d}$ & 3.1 & 21 \\
\hline \multirow{5}{*}{ 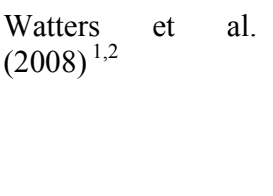 } & Mastitis & $300 \mathrm{~d}$ & 35.0 & 210 \\
\hline & Lameness & $300 \mathrm{~d}$ & 14.0 & 210 \\
\hline & Retained placenta & $300 \mathrm{~d}$ & 8.9 & 210 \\
\hline & Metritis & $300 \mathrm{~d}$ & 19.5 & 210 \\
\hline & Ketosis & $300 \mathrm{~d}$ & 18.6 & 210 \\
\hline \multirow{4}{*}{$\begin{array}{l}\text { Santschi } \\
(2011)^{1}\end{array}$} & Mastitis & $305 \mathrm{~d}$ & 18.4 & 190 \\
\hline & Retained placenta & $21 \mathrm{~d}$ & 19.0 & 190 \\
\hline & Metritis & $21 \mathrm{~d}$ & 7.3 & 190 \\
\hline & Ketosis & $21 \mathrm{~d}$ & 27.1 & 190 \\
\hline \multirow{4}{*}{$\begin{array}{l}\text { Santschi } \\
(2011)^{2}\end{array}$} & Mastitis & $305 \mathrm{~d}$ & 21.1 & 238 \\
\hline & Retained placenta & $21 \mathrm{~d}$ & 11.2 & 238 \\
\hline & Metritis & $21 \mathrm{~d}$ & 4.5 & 238 \\
\hline & Ketosis & $21 \mathrm{~d}$ & 35.5 & 238 \\
\hline
\end{tabular}


Severe NEB and occurrence of metabolic disorders during the transition period (Goff and Horst, 1997, Herdt, 2000, Bertoni et al., 2009) may impair the function of the immune system and consequently increase the risk of infectious diseases such as mastitis (Mallard et al., 1998, Sordillo et al., 2009), and metritis (Enevoldsen and Sørensen, 1992, Butler, 2003, Bertoni et al., 2009). Elevated plasma FFA (Dyk, 1995) and ketone body concentrations (LeBlanc, 2010, Suthar et al., 2013) during the prepartum period were associated with retained placenta and high incidence of puerperal metritis (Wathes et al., 2007b). High concentration of plasma BHB in early lactation was related with an increased risk of clinical mastitis (Leslie et al., 2000). Moreover, severe NEB in early lactation was associated with decreased peripheral blood neutrophil functions (Hammon et al., 2006), decreased titers of natural antibodies (NAb) in plasma (Van Knegsel et al., 2007a), increased plasma haptoglobin levels (Bionaz et al., 2007), decreased cholesterol levels (Turk et al., 2005) and decreased paraoxonase levels (Turk et al., 2004, Turk et al., 2005). As earlier reviewed the relationship between metabolic status, prevalence of infectious diseases and immune suppression and inflammatory responses during transition period is complex (Esposito et al., 2014). Inflammation and dysregulated immune responses have been proposed as the missing link in the pathobiology of metabolic disorders in transition dairy cows (Esposito et al., 2014). Pro-inflammatory cytokines during the transition period stimulated inflammatory responses, decreased feed intake (Dantzer and Kelley, 2007) and related to metabolic disorders (Trevisi et al., 2010). However, questions remain, whether the NEB is a form of inflammation and cause of immune suppression in early lactation.

\subsection{Immune Function and Inflammation}

In dairy cows, inability to adapt effectively to a new lactation is not only related to metabolic stress and increased occurrence of infectious diseases but also to impaired function of the immune system (Goff and Horst, 1997, Bertoni et al., 2008, Sordillo and Aitken, 2009). The immune system is also known as the host defence system and acts with a coordinated response when invaded with complex environmental or pathogenic perturbations (Uthaisangsook et al., 2002). Microorganisms that invade host defense system recognize pathogens by a set of germline-encoded pathogen-recognition receptors (PRRs) (Akira et al., 2001, 
Akira et al., 2006). During infection, the PRRs like toll-like receptors (TLR) and cytoplasmic receptors activate immune cells to mount an inflammatory and immune response (Akira et al., 2006).

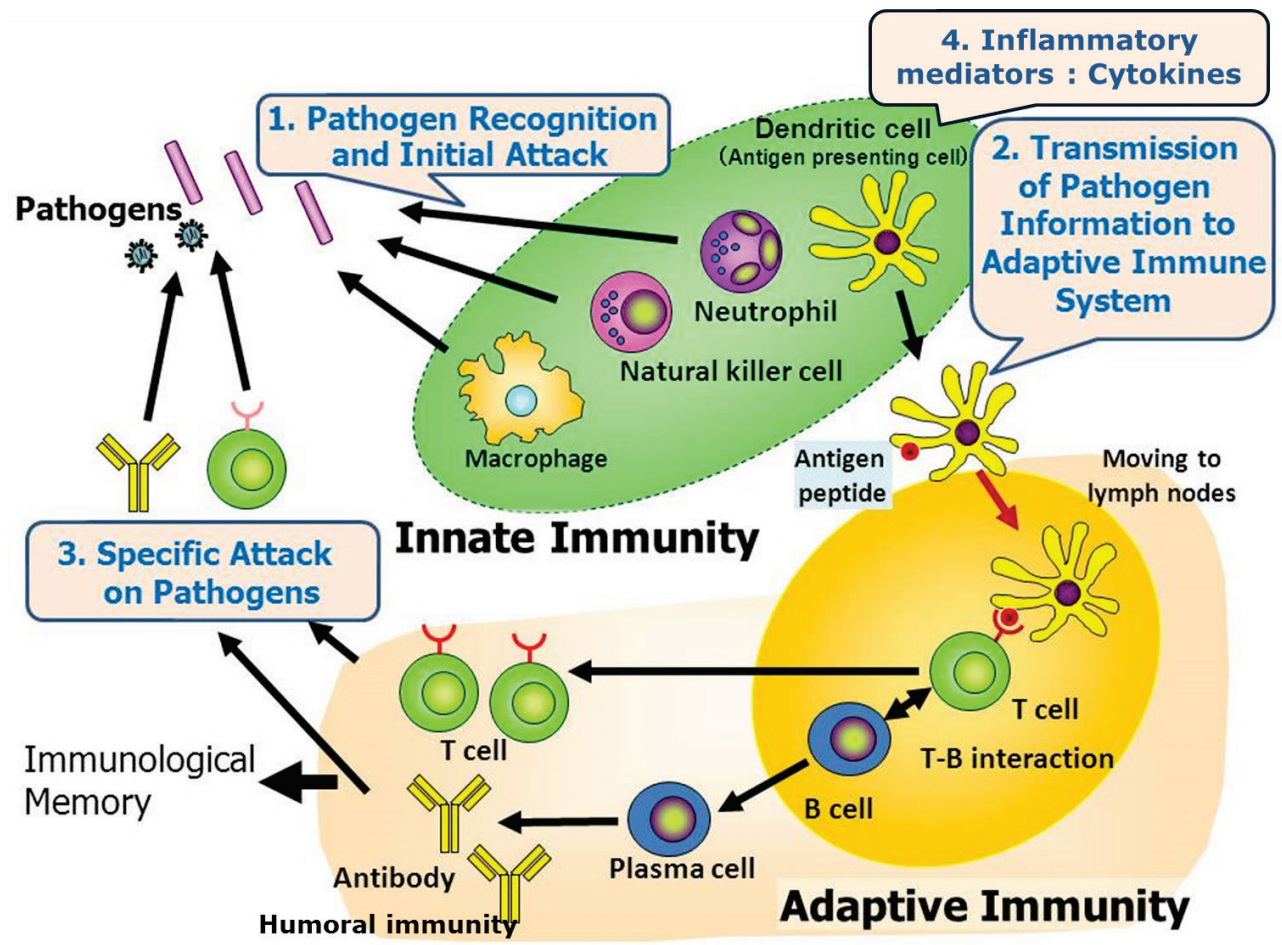

Figure 1.2 Interactions of innate and adaptive immunity. (1) When pathogens invade the body, the innate immune system is activated and participates in the initial attack against the pathogens. (2) Among the cells involved in innate immunity, dendritic cells act as antigen-presenting cells and migrate from the infected tissue to the regional lymph nodes where they present the antigens to $\mathrm{T}$ cells. Subsequently, the adaptive immune system is activated, and antibody production and killer T cells are induced. (3) The resulting antibodies and killer T cells specifically attack the pathogens (4) Soluble innate immunity : cytokines acts as inflammatory mediators to response infection or injury (adapted from Akira, 2011) 


\subsubsection{The Innate and Adaptive Immune System}

As in humans, the immune system in dairy cows can be divided into the innate and adaptive immune system (Akira, 2011). The innate immune system is nonspecific and present since birth and does not require repeated exposure to potential pathogens (Uthaisangsook et al., 2002). Recently, evidence of nonspecific training of innate immunity was obtained in man and mice (Netea, 2013). The adaptive immune system also known as specific immune system is triggered if a pathogen is not completely eliminated by the innate immune system and provide the immunological memory of the infection (Janeway $\mathrm{Jr}$ and Medzhitov, 2002). As the adaptive immune system is responsible for the development of immune memory, this system is associated with repeated exposure (O'Leary et al., 2006, Vivier et al., 2011). Both the innate and adaptive immune system play an important role to provide optimal protection from infectious diseases (Sordillo and Streicher, 2002) and they can be measured in cellular and humoral components of the immune system (Beutler, 2004). Cellular adaptive immunity is mediated by $\mathrm{T}$ lymphocytes (T cells). Humoral adaptive immunity is involved in the eradication of pathogens present in the blood or fluid by generating antibodies, which are produced by B cells (Akira, 2011). T and B cells express unique T-cell receptors (TCRs) and B-cell receptors (BCRs), respectively, and recognize enormous numbers of different antigens (Akira, 2011). Components of the innate immune system are mediated by leukocytes (macrophages, neutrophils, and natural killer cells) and certain soluble mediators (cytokines and eicosanoids) (Sordillo, 2005, Lippolis, 2008). Components of humoral innate immunity include the complement cascades and soluble PRRs (Bottazzi et al., 2009). It is known that the innate and adaptive immunity are closely entangled (Rainard and Riollet, 2006) and share many PRRs such as TLRs (Iwasaki and Medzhitov, 2010) and NOD-like receptor (NLR) (Fritz et al., 2007). The TLRs and NLR present on both innate cells as well as lymphocytes initiating innate and contributing to specific immune response (Fritz et al., 2007, Iwasaki and Medzhitov, 2010). Furthermore, there is accumulating evidence showing that activation of the innate immune system is a prerequisite for the induction of adaptive immune system (Akira et al., 2001, Fritz et al., 2007, Palm and Medzhitov, 2009).

Innate immune system particularly has been indicated to diminish in dairy cows during transition period by several factors such as pregnancy, parturition, 
metabolic stress and hormonal changes in early lactation (Wentink et al., 1997, Lacetera et al. 2002). Pregnancy and parturition are known as a state of immunological depression and consequently increasing the susceptibility to infectious diseases (Mor and Cardenas, 2010). Parturition induces the production of glucocorticoids such as cortisol (Aleri et al., 2016) which induce down regulation of neutrophils and reduce specific immune response capacity (Burton et al., 1995, Preisler et al., 2000, Mallard et al., 2009). During parturition, lactogenesis contributes to decreased function of neutrophils (Kimura et al., 1999). A high progesterone level before parturition reduced polymononuclear (PMN) oxidative burst activity (Moreira da Silva et al., 1997). The phagocytic capacity of macrophages and function of PMN is decreased during parturition and may contribute to increased chronic inflammation and attributed to hormonal changes like interfering the concentration of IGF-1 (Kehrli et al., 1989, Preisler et al., 2000, Kooijman et al., 2012). The changes of diet during transition period affected the number and function of PMN and lymphocytes (Pezeshki et al., 2010). Elevated FFA has been associated with diminished lymphocyte proliferation (Kehrli Jr et al., 1989), and reduced specific immune responsiveness in early lactation (Mallard et al., 1998).

\subsubsection{Inflammation}

The inflammatory response is a part of the innate immune system. Inflammation is a complex biological response against pathogens, removing injurious agents and initiating the tissue healing process (Sordillo et al., 2009). Inflammation is the result of the release of pro-inflammatory cytokines due to metabolic stress or infection (Grimble., 1990). In response to local injury, primary monocytes secrete a number of pro-inflammatory cytokines such as Interleukin (IL)-1, IL-6, and tumor necrosis factor alpha (TNF $\boldsymbol{\alpha}$ ) into the blood stream to attract effector cells and components to combat infection and to induce the liver to produce acute phase proteins (APP) (Gabay and Kushner 1999, Petersen et al., 2004). The liver secretes APP into the blood, which can be used as indicators to assess animal health (Petersen et al., 2004, Gruys et al., 2005). During the infections, levels of APP increase (positive APP, e.g. haptoglobin and 
ceruloplasmin) or decrease (negative APP, e.g. cholesterol and albumin) in plasma (Kushner, 1982, Gruys et al., 1998, Gabay and Kushner, 1999).

Inflammation is categorized as acute or chronic inflammation based on duration of illness, any changes in body condition, the presence or absence of pain and the clinical findings to individual organs or systems (Horadagoda et al., 1999). Acute inflammation is an inflammation which is relatively short in duration from minutes to a few days and characterized by changes in plasma proteins, migration of leukocytes, fever and dullness (Horadagoda et al., 1999). Chronic inflammation is an inflammation which is long in duration (at least a week), and characterized by weight loss and in many cases fever is absent (Horadagoda et al., 1999). In dairy cows, excessive adipose stores and elevated FFA concentration in plasma during transition period have been associated with impaired liver function and increased inflammatory responses (Bionaz et al., 2007, Bertoni et al., 2008) which may result in peroxidative damage of lipids and other macromolecules (Wathes et al., 2009). Inflammatory responses and a dysfunctional immune system can increase the susceptibility to various health problems especially when cows have a high reactive oxygen metabolites (ROM) concentrations in plasma (Bernabucci et al., 2005, Sordillo and Aitken, 2009).

\subsubsection{Natural Antibodies}

Natural antibodies (NAb) are regarded as a humoral part of the innate immune system (Matter and Ochsenbein, 2008, Vollmers and Brändlein, 2009) and are present in healthy individuals without apparent external antigenic stimulation (Ochsenbein and Zinkernagel, 2000). Natural antibodies play an important role in the activation of innate immune responses against infections through neutralization, complement system activation and pathogen elimination (Ochsenbein et al., 1999 and Zinkernagel, 2012). Most NAb are in IgM isotype with low affinity and have polyspecific binding activity (Boes et al., 1998). In mice and humans, NAb are produced by B1 B-cells (Avrameas et al., 2007). In dairy cows, B1 B-cells producing NAb were not definitely found yet but IgM producing B-cells binding keyhole limpet hemocyanin (KLH) were identified (Van Altena, 2016). Natural antibodies have been divided into two classes: overt and cryptic NAb. Overt NAb bind to mostly exogenous antigens that the individual has never encountered before, such as KLH. Cryptic NAb or so-called 
natural autoantibodies (NAAb) are antibodies that bind to self-antigens or slightly changed self-antigens (neo-epitopes). Natural autoantibodies are thought to be involved in inactivation of cytokines, prevention of inflammation, clearance of metabolic waste (cell waste), and perform various homeostatic roles within the immune response (Cojocaru et al., 2009). The involvement of NAAb in auto immune diseases is unknown. In general, low levels of NAAb in plasma have been related with metabolic and behavioural diseases in man (Arai et al., 2013, Hammer et al., 2014). Moreover, once an individual is stimulated by specific antigens, specific antibodies (SpAb) will be produced and the $\mathrm{SpAb}$ are generally more restricted in their epitope recognition with high affinity. Both NAb and $\mathrm{SpAb}$ can be involved by initial recognition and opsonisation of pathogens to activate complement activity (Ehrenstein and Notley, 2010). In dairy cows, NAb (Van Knegsel et al., 2007a, Ploegaert et al., 2010, Van Knegsel et al., 2012, Thompson-Crispi et al., 2013) and NAAb (Van Knegsel et al., 2012) titers are measurable in both plasma and milk. Reduced levels of NAb binding KLH in plasma (Thompson-Crispi et al., 2013) and reduced levels of NAAb binding transferrin in milk (Van Knegsel et al., 2012) are associated with increased risk of clinical mastitis in dairy cows. In dairy cows, levels of NAb and NAAb were related with health status (Van Knegsel et al., 2012, Thompson-Crispi et al., 2013). Maternal antibodies not only provide passive protection to the neonate, but likely also are involved in shaping the neonatal TCR and BCR repertoire by idiotypes and anti-idiotype interaction (Siegrist, 2001, Adkins et al., 2004). Thus lower levels of antibodies in colostrum might affect the specific immune response in calves.

\subsection{Oxidative Stress}

Physiological changes and increased occurrence of health problems during the transition period were associated with oxidative stress. During the transition period, the requirement of oxygen increases due to high metabolic demand and consequently an increased production of reactive oxygen species (ROS) (Spears and Weiss, 2008). An imbalance between increased production of ROS and the availability of antioxidant defence systems such as ferric reduction antioxidant power (FRAP), needed to reduce ROS accumulation, may expose cows to 
increased oxidative stress during the periparturient period (Abuelo et al., 2015). Oxidative stress is often associated with numerous pathologies, but it is not always clear if ROS accumulation is the cause or consequence of health problems (Sordillo et al., 2009). Early studies suggested a role of oxidative stress in the aetiology of disorders in dairy cattle since supplementation with certain antioxidants could decrease the severity of a variety of metabolic and infectious diseases (Miller et al., 1993).

\subsection{How to Improve Energy Balance and Immune Competence in Early Lactation of Dairy Cows?}

\subsubsection{Shortening or Omitting the Dry Period}

In dairy cows, a non-lactating period before calving, also known as the dry period, is a crucial period affecting milk production and health status in the subsequent lactation. A conventional dry period of 60 -d has been applied by farmers since decades to maximize milk production in the first months after calving (Gulay et al., 2003, Grummer and Rastani, 2004, Kuhn et al., 2005). In addition, a dry period of $60-\mathrm{d}$ is used to treat cows with intra-mammary antibiotics to cure existing subclinical mammary infections or to prevent new infections (Smith et al., 1985, Bradley and Green, 2001). The dry period involves mammary involution, a process of cell renewal, followed by a period of mammary epithelial cell proliferation and differentiation (Capuco et al., 1997). In recent years, it is shown that a shortening or omitting the dry period, compared with a conventional dry period of 60-d, improves EB in early lactation. This improvement of the EB due to a short or no dry period is mostly due to a reduced milk production in early lactation (Van Knegsel et al., 2014), sometimes also due to an improvement of dry matter intake (DMI) (Rastani et al., 2005). Both shortening the dry period to about 30-d and omitting the dry period completely decreases milk production in the next lactation, as earlier reviewed (Van Knegsel et al., 2013). This meta-analysis showed that across studies, cows with a short dry period produced $1.4 \mathrm{~kg} / \mathrm{d}$ less milk than cows with a conventional dry period, with an average milk loss of 4.5 percent (range: 3.2 to 13.2 percent). Moreover, cows with no dry period produced $5.9 \mathrm{~kg} / \mathrm{d}$ less milk than cows with a 
conventional dry period, with an average milk loss of 19.1 percent (range: 9.0 to 28.9 percent). Milk production losses in early lactation were partly compensated by additional milk produced in the preceding lactation (Andersen et al., 2005, Rastani et al., 2005). Specifically, this partial shift in milk production from post to pre-calving improves the EB of dairy cows during early lactation (Rastani et al., 2005, Van Knegsel et al., 2014), and consequently an improved body condition in the next lactation (Gulay et al., 2003), improved lymphocyte cell function (Pezeshki et al., 2010), a shorter interval to first ovulation (Gümen et al., 2005, Chen et al., 2015b) and increased incidence of normal resumption of ovarian cyclicity (Chen et al., 2015b) of dairy cows in the subsequent lactation.

The effect of shortening or omitting the dry period on mammary health is not completely clear. A shortened dry period (34 to $40 \mathrm{~d}$ ) did not result in differences in somatic cell count (SCC) (Gulay et al., 2003, Watters et al., 2008, Shoshani et al., 2014), tendency for increased SCC (Rémond et al., 1997, Annen et al., 2004) or tendency for reduced SCC (Rastani et al., 2005) compared with a conventional dry period. A short dry period (34 to $40 \mathrm{~d}$ ) did not affect the incidence of clinical mastitis, compared with a conventional dry period (55 to 65 d) (Enevoldsen and Sørensen, 1992, Watters et al., 2008). Omitting the dry period resulted in higher SCC values compared with cows with a 56-d dry period in some studies (Klusmeyer et al., 2009, Mayasari et al., 2016, Van Hoeij et al., 2016), but not all (Rastani et al., 2005, Köpf et al., 2014). Omitting the dry period did not affect incidence of clinical mastitis (Rémond et al., 1997, Mayasari et al., 2016, Van Hoeij et al., 2016). Cows with clinical mastitis had increased plasma haptoglobin (Eckersall et al., 2001, Grönlund et al., 2005), increased TNF- $\alpha$ and IL-6 in plasma (Nakajima et al., 1997), reduced NAb IgM in plasma (ThompsonCrispi et al., 2013), and increased ROM in plasma (Sordillo and Aitken, 2009). It can be hypothesized that if omitting or shortening the dry period does not affect occurrence of clinical mastitis, also immune competence, inflammatory biomarkers and oxidative stress may not be affected. To our knowledge, the effects of shortening or omitting the dry period in dairy cows on immune competence variables such as plasma NAb and NAAb levels, inflammation biomarkers and oxidative stress variables are not studied yet. In addition, the 
effects of shortening or omitting the dry period over multiple lactations are unknown.

\subsubsection{Dietary Energy Source}

Several dietary strategies have been studied to improve the EB and reduce the incidence and severity of metabolic disorders in early lactation. Most studies aimed at improving the EB by increasing the energy density of the ration by supplementation with dietary fat or non-fibre carbohydrates (Hough et al., 1990, Castañeda-Gutiérrez et al., 2005, Franklin et al., 2005, Dann et al., 2006, Lake et al., 2006, Nowak et al., 2012). However, dietary fat has been suggested to have potential to depress DMI (Palmquist and Jenkins, 1980), which may be explained by limited palatability of dietary fat (Grummer et al., 1990) or possible effects of dietary fat on ruminal fermentation and gut motility (Allen, 2000). Recent studies introduced alternative approaches to improve EB by altering dietary energy sources like feeding a more glucogenic ration in early lactation. Feeding carbohydrates to increase glucogenic nutrients can result in the production of propionate in the rumen or intestinal digested and absorbed as glucose (Van Knegsel et al., 2007b). Moreover, a glucogenic ration in early lactation improved the EB by decreasing milk fat yield compared with a lipogenic ration (Van Knegsel et al., 2007a). Furthermore, in the same study, cows fed a glucogenic ration had lower plasma BHB and liver TAG concentrations and tended to have fewer days postpartum till first ovulation, compared with cows fed a more lipogenic ration. Moreover, a glucogenic ration enhanced plasma NAb titers in early lactation, compared with a more lipogenic ration (Van Knegsel et al., 2007a). To our knowledge it is unknown what are the effects of dietary energy source during early lactation for cows with different dry period lengths on immune competence and inflammation. It can be hypothesized that if EB is improved by shortening or omitting the dry period, the potential beneficial effect of other management factors to improve the EB and metabolic health like the use of glucogenic rations is reduced.

\subsection{Effect of Maternal Dry Period Length on Immune Competence in Calves}

Passive transfer of antibodies from cows to their calves plays an important role in immune development and immune competence of calves. Maternal 
antibodies present in colostrum provide passive immune protection for the newborn calves, as antibodies are not transferred through the placenta (Pravieux et al., 2007) and the adaptive immune system is still immature in young calves (Hasselquist and Nilsson, 2009). Colostrogenesis or prepartum transfer of immunoglobulins from the maternal circulation into mammary secretions is a distinct stage of mammary gland development and starts several weeks before calving (Barrington et al., 2001). Omitting the dry period, but not shortening the dry period, reduced colostrum immunoglobulin content (Baumrucker et al., 2014, Verweij et al., 2014). Earlier studies showed that shortening the dry period to 4 weeks did not affect colostrum immunoglobulin content (Annen et al., 2004, Rastani et al., 2005, Watters et al., 2008, Klusmeyer et al., 2009), pregnancy length (Santschi et al., 2011) and birth weight of calves (Rastani et al., 2005, Pezeshki et al., 2007), compared with a dry period of 56-d. Omission of the dry period, however, reduced colostrum immunoglobulin content (Annen et al., 2004, Rastani et al., 2005, Klusmeyer et al., 2009, Verweij et al., 2014). Adequate and sufficient passive immune transfer of maternal antibodies via colostrum intake may improve the immune competence of calves (Stelwagen et al., 2009), and would reduce the risk of diseases and infections during the pre-weaning period (Oliveira et al., 2010). To our knowledge, the effect of maternal dry period length on natural (auto) antibodies and specific antibodies in plasma of calves is not studied yet.

\subsection{Objectives and Outline of this Thesis}

The objectives of this thesis were (1) to investigate effects of dry period length and dietary energy source on immune competence, inflammatory biomarkers and oxidative stress in dairy cows in the transition period from pregnancy to lactation, 2) to investigate the consequences of maternal dry period length on immunoglobulin content in colostrum and the immune competence in calves. For this study, 167 Holstein-Friesian dairy cows were selected from the Dairy Campus research herd (WUR Livestock Research, Lelystad, the Netherlands), blocked according to parity, calving date, milk yield in previous lactation, and body condition score (BCS), and randomly assigned to treatments within blocks. Treatments consisted of 3 dry period lengths $(0,30$ or $60 \mathrm{~d})$ and 2 
early lactation rations (glucogenic or lipogenic) resulting in a $3 \times 2$ factorial design. Cows used in this study were clinically healthy at start of the experiment. Plasma and milk samples around the transition period were obtained and analysed for immune competence, inflammatory biomarkers and oxidative stress. Colostrum samples were collected to determine immunoglobulin content. Subsequently the effects of dry period lengths and dietary treatments on health status were assessed. Secondly, humoral immune status and natural (auto) antibodies and specific antibodies in plasma of the calves were determined. The effects of 3 dry period length $(0,30$ and $60 \mathrm{~d})$ and 2 early lactation rations (glucogenic or lipogenic) on energy balance (Van Knegsel et al., 2014, Chen et al., 2016) and metabolic status in the first and second subsequent lactations in the current experiment have been reported earlier (Chen et al., 2015a, Chen et al., 2016).

The outline of this thesis is as follows:

Chapter 2 covers the determination of inflammatory biomarkers and oxidative stress variables in plasma in cows in the transition phase from pregnancy to lactation of the first lactation after implementation of dry period length and dietary treatments

In chapter 3 covers the determination of inflammatory biomarkers and oxidative stress in plasma of cows in the second lactation after implementation of dry period length and dietary treatments were related to uterine health.

Chapter 4 covers the estimation of NAb titers and mammary health in dairy cows with different dry period length and dietary treatment for 2 subsequent lactations. In addition, the relationships between NAb titers and mammary health are determined.

Chapter 5 and 6 focus on the effect of maternal dry period length on immunoglobulin content in colostrum and immune competence of calves.

Finally, chapter 7 discusses the biological mechanisms behind the effects of shortening or omitting dry period on immune competence, inflammatory biomarkers and oxidative stress and includes the conclusions of this $\mathrm{PhD}$ thesis. 


\section{References}

Abuelo, A., J. Hernández, J. L. Benedito, and C. Castillo. 2015. The importance of the oxidative status of dairy cattle in the periparturient period: Revisiting antioxidant supplementation. J. Anim. Physio. and Anim. Nut. 99:1003-1016.

Akira, S. 2011. Innate immunity and adjuvants. Philosophical Transactions of the Royal Society B: Bio. Sci. 366:2748-2755.

Akira, S., K. Takeda, and T. Kaisho. 2001. Toll-like receptors: critical proteins linking innate and acquired immunity. Nat. immuno. 2:675-680.

Akira, S., S. Uematsu, and O. Takeuchi. 2006. Pathogen recognition and innate immunity. Cell 124:783-801.

Aleri, J. W., B. C. Hine, M. F. Pyman, P. D. Mansell, W. J. Wales, B. Mallard, and A. D. Fisher. 2016. Periparturient immunosuppression and strategies to improve dairy cow health during the periparturient period. Res.Vet. Sci. 108:8-17.

Allen, M. S. 2000. Effects of diet on short-term regulation of feed intake by lactating dairy cattle. J. Dairy Sci. 83:1598-1624.

Amory, J. R., Z. E. Barker, J. L. Wright, S. A. Mason, R. W. Blowey, and L. E. Green. 2008. Associations between sole ulcer, white line disease and digital dermatitis and the milk yield of 1824 dairy cows on 30 dairy cow farms in England and Wales from February 2003-November 2004. Prev. Vet. Med. 83:381-391.

Andersen, J. B., T. G. Madsen, T. Larsen, K. L. Ingvartsen, and M. O. Nielsen. 2005. The effects of dry period versus continuous lactation on metabolic status and performance in periparturient cows. J. Dairy Sci. 88:3530-3541.

Annen, E. L., R. J. Collier, M. A. McGuire, J. L. Vicini, J. M. Ballam, and M. J. Lormore. 2004. Effect of modified dry period lengths and bovine somatotropin on yield and composition of milk from dairy cows. J. Dairy Sc 87:3746-3761.

Arai, S., N. Maehara, Y. Iwamura, S. Honda, K. Nakashima, T. Kai, M. Ogishi, K. Morita, J. Kurokawa, and M. Mori. 2013. Obesity-associated autoantibody production requires AIM to retain the immunoglobulin $\mathrm{M}$ immune complex on follicular dendritic cells. Cell reports 3:1187-1198.

Avrameas, S., T. Ternynck, I. A. Tsonis, and P. Lymberi. 2007. Naturally occurring Bcell autoreactivity: A critical overview. J. Autoimmunity 29:213-218.

Barkema, H. W., M. A. G. von Keyserlingk, J. P. Kastelic, T. J. G. M. Lam, C. Luby, J. P. Roy, S. J. LeBlanc, G. P. Keefe, and D. F. Kelton. 2015. Invited review: Changes in the dairy industry affecting dairy cattle health and welfare. J. Dairy Sci. 98:7426-7445.

Barrington, G. M., T. B. McFadden, M. T. Huyler, and T. E. Besser. 2001. Regulation of colostrogenesis in cattle. Livestock Prod. Sci. 70:95-104.

Baumrucker, C. R., R. S. Zbinden, H. A. van Dorland, G. J. Remmelink, B. Kemp, A. T. M. van Knegsel, and R. M. Bruckmaier. 2014. Continuous milking of dairy cows disrupts timing of peak IgG concentration appearance in mammary secretions. J. Dairy Res.:1-7. 
Beam, S. W. and W. R. Butler. 1997. Energy balance and ovarian follicle development prior to the first ovulation postpartum in dairy cows receiving three levels of dietary fat. Biol. Reprod. 56:133-142.

Beaudeau, F., V. Ducrocq, C. Fourichon, and H. Seegers. 1995. Effect of disease on length of productive life of French Holstein dairy cows assessed by survival analysis. J. Dairy Sci. 78:103-117.

Bernabucci, U., B. Ronchi, N. Lacetera, and A. Nardone. 2005. Influence of body condition score on relationships between metabolic status and oxidative stress in periparturient dairy cows. J. Dairy Sci. 88:2017-2026.

Bertoni, G., E. Trevisi, X. Han, and M. Bionaz. 2008. Effects of inflammatory conditions on liver activity in puerperium period and consequences for performance in dairy cows. J. Dairy Sci. 9:3300-3310.

Bertoni, G., E. Trevisi, and R. Lombardelli. 2009. Some new aspects of nutrition, health conditions and fertility of intensively reared dairy cows. Italian J. Animal Sci.8:491-518.

Beutler, B. 2004. Innate immunity: an overview. Mol. Immuno.y 40:845-859.

Bionaz, M., E. Trevisi, L. Calamari, F. Librandi, A. Ferrari, and G. Bertoni. 2007. Plasma paraoxonase, health, inflammatory conditions, and liver function in transition dairy cows. J. Dairy Sci. 90:1740-1750.

Boes, M., A. P. Prodeus, T. Schmidt, M. C. Carroll, and J. Chen. 1998. A critical role of natural immunoglobulin $\mathrm{M}$ in immediate defense against systemic bacterial infection. Journal of Experimental Medicine 188:2381-2386.

Booth, C. J., L. D. Warnick, Y. T. Gröhn, D. O. Maizon, C. L. Guard, and D. Janssen. 2004. Effect of lameness on culling in dairy cows. J. Dairy Sci. 87:4115-4122.

Bottazzi, B., C. Garlanda, A. Cotena, F. Moalli, S. Jaillon, L. Deban, and A. Mantovani. 2009. The long pentraxin PTX3 as a prototypic humoral pattern recognition receptor: interplay with cellular innate immunity. Immuno. Rev. 227:9-18.

Bradley, A. J. and M. J. Green. 2001. An investigation of the impact of intramammary antibiotic dry cow therapy on clinical coliform mastitis. J. Dairy Sci. 84:16321639.

Burton, J. L., M. E. Kehrli, S. Kapil, and R. L. Horst. 1995. Regulation of L-selectin and CD18 on bovine neutrophils by glucocorticoids: effects of cortisol and dexamethasone. J. Leukocyte Biol. 57:317-325.

Butler, W. R. 2003. Energy balance relationships with follicular development, ovulation and fertility in postpartum dairy cows. Livestock Prod. Sci. 83:211-218.

Butler, W. R. and R. D. Smith. 1989. Interrelationships between energy balance and postpartum reproductive function in dairy cattle. J. Dairy Sci. 72:767-783.

Capuco, A. V., R. M. Akers, and J. J. Smith. 1997. Mammary growth in holstein cows during the dry period: quantification of nucleic acids and histology. J. Dairy Sci. 80:477-487.

Carlén, E., E. Strandberg, and A. Roth. 2004. Genetic parameters for clinical mastitis, somatic cell score, and production in the first three lactations of swedish holstein cows. J. Dairy Sci. 87:3062-3070. 
Castañeda-Gutiérrez, E., T. R. Overton, W. R. Butler, and D. E. Bauman. 2005. Dietary supplements of two doses of calcium salts of conjugated linoleic acid during the transition period and early lactation. J. Dairy Sci. 88:1078-1089.

Chen, J., J. J. Gross, H. A. van Dorland, G. J. Remmelink, R. M. Bruckmaier, B. Kemp, and A. T. M. van Knegsel. 2015a. Effects of dry period length and dietary energy source on metabolic status and hepatic gene expression of dairy cows in early lactation. J. Dairy Sci. 98:1033-1045.

Chen, J., G. J. Remmelink, J. J. Gross, R. M. Bruckmaier, B. Kemp, and A. T. M. van Knegsel. 2016. Effects of dry period length and dietary energy source on milk yield, energy balance, and metabolic status of dairy cows over 2 consecutive years: Effects in the second year. J. Dairy Sci. 99:1-13.

Chen, J., N. M. Soede, H. A. van Dorland, G. J. Remmelink, R. M. Bruckmaier, B. Kemp, and A. T. M. van Knegsel. 2015b. Relationship between metabolism and ovarian activity in dairy cows with different dry period lengths. Theriogenology 84:13871396.

Chiumia, D., M. G. G. Chagunda, A. I. Macrae, and D. J. Roberts. 2013. Predisposing factors for involuntary culling in Holstein-Friesian dairy cows. J. Dairy Res. $80: 45-50$.

Cojocaru, M., I. M. Cojocaru, and I. Silosi. 2009. The significance of natural autoantibodies. Maedica (Buchar) 4:22-25.

Collard, B. L., P. J. Boettcher, J. C. M. Dekkers, D. Petitclerc, and L. R. Schaeffer. 2000. Relationships between energy balance and health traits of dairy cattle in early lactation. J. Dairy Sci. 83:2683-2690.

Dann, H., N. Litherland, J. Underwood, M. Bionaz, A. D’angelo, J. McFadden, and J. Drackley. 2006. Diets during far-off and close-up dry periods affect periparturient metabolism and lactation in multiparous cows. J. Dairy Sci. 89:3563-3577.

Dantzer, R. and K. W. Kelley. 2007. Twenty years of research on cytokine-induced sickness behavior. Brain Behav. Immun. 21:153-160.

Drackley, J. K. 1999. Biology of dairy cows during the transition period: The final frontier? J. Dairy Sci. 82:2259-2273.

Dyk, P. B. 1995. The association of prepartum non-esterified fatty acids and body condition with peripartum health problems on 95 Michigan dairy farms. M.S. Thesis, Michigan State Univ., East Lansing.

Eckersall, P. D., F. J. Young, C. McComb, C. J. Hogarth, S. Safi, A. Weber, T. McDonald, A. M. Nolan, and J. L. Fitzpatrick. 2001. Acute phase proteins in serum and milk from dairy cows with clinical mastitis. Vet. Rec. 148:35-41.

Ehrenstein, M. R. and C. A. Notley. 2010. The importance of natural IgM: scavenger, protector and regulator. Nat. Rev.Immuno. 10:778-786.

Enevoldsen, C. and J. T. Sørensen. 1992. Effects of dry period length on clinical mastitis and other major clinical health disorders. J. Dairy Sci. 75:1007-1014.

Esposito, G., P. C. Irons, E. C. Webb, and A. Chapwanya. 2014. Interactions between negative energy balance, metabolic diseases, uterine health and immune response in transition dairy cows. Animal Reprod. Sci. 144:60-71. 
Fleischer, P., M. Metzner, M. Beyerbach, M. Hoedemaker, and W. Klee. 2001. The relationship between milk yield and the incidence of some diseases in dairy cows. J. Dairy Sci 84:2025-2035.

Franklin, S. T., M. C. Newman, K. E. Newman, and K. I. Meek. 2005. Immune parameters of dry cows fed mannan oligosaccharide and subsequent transfer of immunity to calves. J. Dairy Sci. 88:766-775.

Fritz, J. H., L. Le Bourhis, G. Sellge, J. G. Magalhaes, H. Fsihi, T. A. Kufer, C. Collins, J. Viala, R. L. Ferrero, and S. E. Girardin. 2007. Nod1-mediated innate immune recognition of peptidoglycan contributes to the onset of adaptive immunity. Immunity 26:445-459.

Gabay, C. and I. Kushner 1999. Acute-phase proteins and other systemic responses to inflammation. New Engl. J. Med. 340:448-454

Garbarino, E. J., J. A. Hernandez, J. K. Shearer, C. A. Risco, and W. W. Thatcher. 2004. Effect of lameness on ovarian activity in postpartum Holstein cows. J. Dairy Sci. 87:4123-4131.

Goff, J. P. and R. L. Horst. 1997. Physiological changes at parturition and their relationship to metabolic disorders. J. Dairy Sci. 80.

Green, L. E., V. J. Hedges, Y. H. Schukken, R. W. Blowey, and A. J. Packington. 2002. The impact of clinical lameness on the milk yield of dairy cows. J. Dairy Sci. 85:2250-2256.

Grimble, R. F. 1990. Nutrition and cytokine action. Nut. Res. Rev. 3:193-210.

Grönlund, U., C. H. Sandgren, and K. P. Waller. 2005. Haptoglobin and serum amyloid A in milk from dairy cows with chronic sub-clinical mastitis. Vet. Res. 36:191-198.

Gross, J., H. A. van Dorland, F. J. Schwarz, and R. M. Bruckmaier. 2011. Endocrine changes and liver mRNA abundance of somatotropic axis and insulin system constituents during negative energy balance at different stages of lactation in dairy cows. J. Dairy Sci. 94:3484-3494.

Grummer, R. R. 1993. Etiology of lipid-related metabolic disorders in periparturient dairy cows. J. Dairy Sci. 76:3882-3896.

Grummer, R. R. 1995. Impact of changes in organic nutrient metabolism on feeding the transition dairy cow. J. Animal Sci.73:2820-2833.

Grummer, R. R., M. L. Hatfield, and M. R. Dentine. 1990. Acceptability of fat supplements in four dairy herds. J. Dairy Sci. 73:852-857.

Grummer, R. R. and R. R. Rastani. 2004. Why reevaluate dry period length? J. Dairy Sci. 87:E77-E85.

Gruys, E., M. J. M. Toussaint, W. J. M. Landman, M. Tivapasi, R. Chamanza, and L. Van Veen. 1998. Infection, inflammation and stress inhibit growth. Mechanisms and non-specific assessment of the processes by acute phase proteins. Pages 72-87 in Proc. Production diseases in farm animals. 10th International conference.

Gruys, E., M. J. M. Toussaint, T. A. Niewold, and S. J. Koopmans. 2005. Acute phase reaction and acute phase proteins. J Zhejiang Univ: Sci 6 B:1045-1056.

Gulay, M. S., M. J. Hayen, K. C. Bachman, T. Belloso, M. Liboni, and H. H. Head. 2003. Milk production and feed intake of holstein cows given short (30-d) or normal (60d) dry periods. J. Dairy Sci 86:2030-2038. 
Gümen, A., R. R. Rastani, R. R. Grummer, and M. C. Wiltbank. 2005. Reduced dry periods and varying prepartum diets alter postpartum ovulation and reproductive measures. J. Dairy Sci. 88:2401-2411.

Hammer, C., B. Stepniak, A. Schneider, S. Papiol, M. Tantra, M. Begemann, A. L. Siren, L. A. Pardo, S. Sperling, and S. M. Jofrry. 2014. Neuropsychiatric disease relevance of circulating anti-NMDA receptor autoantibodies depends on bloodbrain barrier integrity. Molecular psychiatry 19:1143-1149.

Hammon, D. S., I. M. Evjen, T. R. Dhiman, J. P. Goff, and J. L. Walters. 2006. Neutrophil function and energy status in Holstein cows with uterine health disorders. Vet. Immuno. Immunopath. 113:21-29.

Hammon, H. M., G. Stürmer, F. Schneider, A. Tuchscherer, H. Blum, T. Engelhard, A. Genzel, R. Staufenbiel, and W. Kanitz. 2009. Performance and metabolic and endocrine changes with emphasis on glucose metabolism in high-yielding dairy cows with high and low fat content in liver after calving. J. Dairy Sci. 92:15541566 .

Hasselquist, D. and J. Nilsson. 2009. Maternal transfer of antibodies in vertebrates: transgenerational effects on offspring immunity. Philosophical Transactions of the Royal Society of London B: Bio. Sci. 364:51-60.

Herdt, T. H. 2000. Ruminant adaptation to negative energy balance: Influences on the etiology of ketosis and fatty liver. Veterinary Clinics of North America: Food Animal Prac. 16:215-230.

Heuer, C., Y. H. Schukken, and P. Dobbelaar. 1999. Postpartum body condition score and results from the first test day milk as predictors of disease, fertility, yield, and culling in commercial dairy herds. J. Dairy Sci 82:295-304.

Hogeveen, H., K. Huijps, and T. J. G. M. Lam. 2011. Economic aspects of mastitis: New developments. N. Z. Vet. J. 59:16-23.

Horadagoda, N. U., K. M. Knox, H. A. Gibbs, S. W. Reid, A. Horadagoda, S. E. Edwards, and P. D. Eckersall. 1999. Acute phase proteins in cattle: discrimination between acute and chronic inflammation. Vet. Rec. 144:437-441.

Hough, R. L., F. D. McCarthy, H. D. Kent, D. E. Eversole, and M. L. Wahlberg. 1990. Influence of nutritional restriction during late gestation on production measures and passive immunity in beef cattle. J. Animal Sci. 68:2622-2627.

Iwasaki, A. and R. Medzhitov. 2010. Regulation of adaptive immunity by the innate immune system. Sci. 327:291-295.

Janeway Jr, C. A. and R. Medzhitov. 2002. Innate immune recognition. Ann. Rev. Immuno. 20:197-216.

Kehrli Jr, M. E., B. J. Nonnecke, and J. A. Roth. 1989. Alterations in bovine lymphocyte function during the periparturient period. Am. J. Vet. Res. 50:215-220.

Kimura, K., J. P. Goff, and M. E. Kehrli Jr. 1999. Effects of the presence of the mammary gland on expression of neutrophil adhesion molecules and myeloperoxidase activity in periparturient dairy cows. J. Dairy Sci. 82:2385-2392.

Klusmeyer, T. H., A. C. Fitzgerald, A. C. Fabellar, J. M. Ballam, R. A. Cady, and J. L. Vicini. 2009. Effect of recombinant bovine somatotropin and a shortened or no dry period on the performance of lactating dairy cows. J. Dairy Sci 92:5503-5511. 
Koeck, A., F. Miglior, D. F. Kelton, and F. S. Schenkel. 2012. Short Communication: Genetic association of body condition score with disease resistance in first lactation Canadian Holsteins. Can. J. Anim. Sci. 92:285-289.

Kuhn, M. T., J. L. Hutchison, and H. D. Norman. 2005. Minimum days dry to maximize milk yield in subsequent lactation. Anim. Res. 54:351-367.

Kushner, I. 1982. The phenomenon of the acute phase response. Annals of the New York Acad.Sci. 389:39-48.

Lake, S., E. Scholljegerdes, W. Small, E. Belden, S. Paisley, D. Rule, and B. Hess. 2006. Immune response and serum immunoglobulin $G$ concentrations in beef calves suckling cows of differing body condition score at parturition and supplemented with high-linoleate or high-oleate safflower seeds. J. Animal Sci. 84:997-1003.

LeBlanc, S. J. 2010. Monitoring metabolic health of dairy cattle in the transition period. J. Reprod. Develop. 56:S29-S35.

LeBlanc, S. J., T. F. Duffield, K. E. Leslie, K. G. Bateman, J. TenHag, J. S. Walton, and W. H. Johnson. 2002. The effect of prepartum injection of vitamin e on health in transition dairy cows. J. Dairy Sci. 85:1416-1426.

Leslie, K. E., T. F. Duffield, Y. H. Schukken, and S. J. LeBlanc. 2000. The influence of negative energy balance on udder health. Pages 25-33 in Proc. Proc. Natl. Mast. Counc. Regional Meeting. Citeseer.

Mallard, B. A., J. C. Dekkers, M. J. Ireland, K. E. Leslie, S. Sharif, C. L. Vankampen, L. Wagter, and B. N. Wilkie. 1998. Alteration in immune responsiveness during the peripartum period and its ramification on dairy cow and calf health. J. Dairy Sci. 81:585-595.

Mallard, B. A., B. W. McBride, M. E. Kehrli, and P. M. Coussens. 2009. Bovine immunophysiology and genetics: A review of the research and career of Jeanne L. Burton. Vet. Immuno. Immunopath.128:96-103.

Mayasari, N., W. Rijks, G. de Vries Reilingh, G. J. Remmelink, B. Ducro, B. Kemp, H. K. Parmentier, and A. T. M. Van Knegsel. 2016. The effects of dry period length and dietary energy source on natural antibody titers and mammary health in dairy cows. Prev. Vet. Med. 127:1-9.

Mor, G. and I. Cardenas. 2010. The immune system in pregnancy: A unique complexity. American J. Reprod. Immuno. (New York, N.Y. : 1989) 63:425-433.

Nakajima, Y., O. Mikami, M. Yoshioka, Y. Motoi, T. Ito, Y. Ishikawa, M. Fuse, K. Nakano, and K. Yasukawa. 1997. Elevated levels of tumor necrosis factor- $\alpha,($ TNF$\alpha$ ) and interleukin-6 (IL-6) activities in the sera and milk of cows with naturally occurring coliform mastitis. Res. Vet. Sci. 62:297-298.

Netea, M. G. 2013. Training innate immunity: the changing concept of immunological memory in innate host defence. Eur. J. Clin. Invest. 43:881-884.

Nowak, W., R. Mikuła, A. Zachwieja, K. Paczyńska, E. Pecka, K. Drzazga, and P. Ślósarz. 2012. The impact of cow nutrition in the dry period on colostrum quality and immune status of calves. Pol. J. Vet. Sci. 15:77-82.

O'Leary, J. G., M. O. Goodarzi, D. L. Drayton, and U. H. von Andrian. 2006. T cell-and B cell-independent adaptive immunity mediated by natural killer cells. Nat. Immuno. 7:507-516. 
Oliveira, R. A., C. D. Narciso, R. S. Bisinotto, M. C. Perdomo, M. A. Ballou, M. Dreher, and J. E. P. Santos. 2010. Effects of feeding polyphenols from pomegranate extract on health, growth, nutrient digestion, and immunocompetence of calves. J. Dairy Sci. 93:4280-4291.

Palm, N. W. and R. Medzhitov. 2009. Pattern recognition receptors and control of adaptive immunity. Immuno. Rev. 227:221-233.

Palmquist, D. L. and T. C. Jenkins. 1980. Fat in lactation rations 1, 2: Review. J. Dairy Sci. 63:1-14.

Petersen, H. H., J. P. Nielsen, and P. M. H. Heegaard. 2004. Application of acute phase protein measurements in veterinary clinical chemistry. Vet. Res. 35:163-187.

Pezeshki, A., A. V. Capuco, B. De Spiegeleer, L. Peelman, M. Stevens, R. J. Collier, and C. Burvenich. 2010. Review article: An integrated view on how the management of the dry period length of lactating cows could affect mammary biology and defence. J. Anim. Physio. Anim. Nut. 94:e7-e30.

Pezeshki, A., J. Mehrzad, G. R. Ghorbani, H. R. Rahmani, R. J. Collier, and C. Burvenich. 2007. Effects of short dry periods on performance and metabolic status in holstein dairy cows. J. Dairy Sci. 90:5531-5541.

Ploegaert, T., S. Wijga, E. Tijhaar, J. Van der Poel, T. Lam, H. Savelkoul, H. Parmentier, and J. Van Arendonk. 2010. Genetic variation of natural antibodies in milk of Dutch Holstein-Friesian cows. J. Dairy Sci. 93:5467-5473.

Pravieux, J. J., H. Poulet, C. Charreyre, and V. Juillard. 2007. Protection of newborn animals through maternal immunization. J. Comp. Pathol. 137:S32-S34.

Preisler, M. T., P. S. D. Weber, R. J. Tempelman, R. J. Erskine, H. Hunt, and J. L. Burton. 2000. Glucocorticoid receptor down-regulation in neutrophils of periparturient cows. Am J Vet Res 61:14-19.

Rainard, P. and C. Riollet. 2006. Innate immunity of the bovine mammary gland. Vet. Res. 37:369-400.

Rajala-Schultz, P. J., Y. T. Gröhn, and C. E. McCulloch. 1999. Effects of milk fever, ketosis, and lameness on milk yield in dairy cows. J. Dairy Sci. 82:288-294.

Rastani, R. R., R. R. Grummer, S. J. Bertics, A. Gümen, M. C. Wiltbank, D. G. Mashek, and M. C. Schwab. 2005. Reducing dry period length to simplify feeding transition cows: milk production, energy balance, and metabolic profiles. J. Dairy Sci. 88:1004-1014.

Rémond, B., J. Kérouanton, and V. Brocard. 1997. Effets de la réduction de la durée de la période séche ou de son omission sur les performances des vaches laitiéras. INRA Prod. Anim.:301-333.

Roberts, T., N. Chapinal, S. J. LeBlanc, D. F. Kelton, J. Dubuc, and T. F. Duffield. 2012. Metabolic parameters in transition cows as indicators for early-lactation culling risk. J. Dairy Sci. 95:3057-3063.

Santschi, D. E., D. M. Lefebvre, R. I. Cue, C. L. Girard, and D. Pellerin. 2011. Incidence of metabolic disorders and reproductive performance following a short (35-d) or conventional (60-d) dry period management in commercial Holstein herds. J. Dairy Sci. 94:3322-3330. 
Seifi, H. A., S. J. LeBlanc, K. E. Leslie, and T. F. Duffield. 2011. Metabolic predictors of post-partum disease and culling risk in dairy cattle. The Vet. J. 188:216-220.

Sheldon, I. M., J. Cronin, L. Goetze, G. Donofrio, and H. J. Schuberth. 2009. Defining postpartum uterine disease and the mechanisms of infection and immunity in the female reproductive tract in cattle. Biol. Reprod. 8:1025-1032.

Smith, K. L., D. A. Todhunter, and P. S. Schoenberger. 1985. Environmental pathogens and intramammary infection during the dry period 1, 2. J. Dairy Sci. 68:402-417.

Sordillo, L. M. and S. L. Aitken. 2009. Impact of oxidative stress on the health and immune function of dairy cattle. Vet. Immuno. Immunopath.128:104-109.

Sordillo, L. M., G. Contreras, and S. L. Aitken. 2009. Metabolic factors affecting the inflammatory response of periparturient dairy cows. Anim. Health Res. Rev 10:5363.

Sordillo, L. M. and K. L. Streicher. 2002. Mammary gland immunity and mastitis susceptibility. J. Mammary Gland Biol. Neoplasia 7:135-146.

Spears, J. W. and W. P. Weiss. 2008. Role of antioxidants and trace elements in health and immunity of transition dairy cows. The Vet. J. 176:70-76.

Stelwagen, K., E. Carpenter, B. Haigh, A. Hodgkinson, and T. T. Wheeler. 2009. Immune components of bovine colostrum and milk. J. Anim. Sci. 87:3-9.

Suthar, V. S., J. Canelas-Raposo, A. Deniz, and W. Heuwieser. 2013. Prevalence of subclinical ketosis and relationships with postpartum diseases in European dairy cows. J. Dairy Sci. 96:2925-2938.

Thompson-Crispi, K. A., F. Miglior, and B. A. Mallard. 2013. Genetic parameters for natural antibodies and associations with specific antibody and mastitis in Canadian Holsteins. J. Dairy Sci. 96:3965-3972.

Trevisi, E., A. Ferrari, F. Piccioli-Cappelli, P. Grossi, and G. Bertoni. 2010. An additional study on the relationship between the inflammatory condition at calving time and net energy efficiency in dairy cows. Energy and protein metabolism and nutrition. EAAP Publ:489-490.

Turk, R., D. Juretić, D. Gereš, N. Turk, B. Rekić, V. Simeon-Rudolf, M. Robić, and A. Svetina. 2005. Serum paraoxonase activity in dairy cows during pregnancy. Res. Vet. Sci. 79:15-18.

Turk, R., D. Juretic, D. Geres, N. Turk, B. Rekic, V. Simeon-Rudolf, and A. Svetina. 2004. Serum paraoxonase activity and lipid parameters in the early postpartum period of dairy cows. Res. Vet. Sci. 76:57-61.

Uthaisangsook, S., N. K. Day, S. L. Bahna, R. A. Good, and S. Haraguchi. 2002. Innate immunity and its role against infections. Annals of Allergy, Asthma \& Immuno. 88:253-265.

Van Altena, S. E. C. 2016. Biomarkers and mechanisms of natural disease resistance in dairy cows. Wageningen University.

Van Hoeij, R., T. Lam, D. de Koning, W. Steeneveld, B. Kemp, and A. van Knegsel. 2016. Cow characteristics and their association with udder health after different dry period lengths. J. Dairy Sci. 99:8330-8340.

Van Knegsel, A. T. M., G. de Vries Reilingh, S. Meulenberg, H. van den Brand, J. Dijkstra, B. Kemp, and H. K. Parmentier. 2007a. Natural antibodies related to energy balance in early lactation dairy cows. J. Dairy Sci. 90:5490-5498. 
Van Knegsel, A. T. M., M. Hostens, G. de Vries Reilingh, A. Lammers, B. Kemp, G. Opsomer, and H. K. Parmentier. 2012. Natural antibodies related to metabolic and mammary health in dairy cows. Prev Vet Med 103:287-297.

Van Knegsel, A. T. M., G. J. Remmelink, S. Jorjong, V. Fievez, and B. Kemp. 2014. Effect of dry period length and dietary energy source on energy balance, milk yield, and milk composition of dairy cows. J. Dairy Sci. 97:1499-1512.

Van Knegsel, A. T. M., H. van den Brand, J. Dijkstra, W. M. van Straalen, R. Jorritsma, S. Tamminga, and B. Kemp. 2007b. Effect of glucogenic vs. lipogenic diets on energy balance, blood metabolites, and reproduction in primiparous and multiparous dairy cows in early lactation. J. Dairy Sci. 90:3397-3409.

Van Knegsel, A. T. M., S. G. A. van der Drift, J. Čermáková, and B. Kemp. 2013. Effects of shortening the dry period of dairy cows on milk production, energy balance, health, and fertility: A systematic review. The Vet. J. 198:707-713.

Veenhuizen, J. J., J. K. Drackley, M. J. Richard, T. P. Sanderson, L. D. Miller, and J. W. Young. 1991. Metabolic changes in blood and liver during development and early treatment of experimental fatty liver and ketosis in cows. J. Dairy Sci. 74:42384253.

Verweij, J. J., A. P. Koets, and S. W. F. Eisenberg. 2014. Effect of continuous milking on immunoglobulin concentrations in bovine colostrum. Vet. Immuno. Immunopath. 160:225-229.

Vivier, E., D. H. Raulet, A. Moretta, M. A. Caligiuri, L. Zitvogel, L. L. Lanier, W. M. Yokoyama, and S. Ugolini. 2011. Innate or adaptive immunity? The example of natural killer cells. Sci. 331:44-49.

Walsh, S. W., E. J. Williams, and A. C. O. Evans. 2011. A review of the causes of poor fertility in high milk producing dairy cows. Anim. Reprod. Sci. 123:127-138.

Wathes, D. C., Z. Cheng, N. Bourne, V. J. Taylor, M. P. Coffey, and S. Brotherstone. 2007a. Differences between primiparous and multiparous dairy cows in the interrelationships between metabolic traits, milk yield and body condition score in the periparturient period. Domest. Anim. Endocrinol. 33:203-225.

Wathes, D. C., Z. Cheng, W. Chowdhury, M. A. Fenwick, R. Fitzpatrick, D. G. Morris, J. Patton, and J. J. Murphy. 2009. Negative energy balance alters global gene expression and immune responses in the uterus of postpartum dairy cows. Physio. Gen. 39:1-13.

Wathes, D. C., M. A. Fenwick, Z. Cheng, N. Bourne, S. Llewellyn, D. G. Morris, D. Kenny, J. J. Murphy, and R. Fitzpatrick. 2007b. Influence of negative energy balance on cyclicity and fertility in the high producing dairy cow. Theriogeno. 68:S232-S241.

Watters, R. D., J. N. Guenther, A. E. Brickner, R. R. Rastani, P. M. Crump, P. W. Clark, and R. R. Grummer. 2008. Effects of dry period length on milk production and health of dairy cattle. J. Dairy Sci. 91:2595-2603.

Whay, H. R., A. E. Waterman, and A. J. F. Webster. 1997. Associations between locomotion, claw lesions and nociceptive threshold in dairy heifers during the peripartum period. Vet. J. 154:155-161. 
Zwald, N. R., K. A. Weigel, Y. M. Chang, R. D. Welper, and J. S. Clay. 2004. Genetic selection for health traits using producer-recorded data. I. Incidence rates, heritability estimates, and sire breeding values. J. Dairy Sci. 87:4287-4294. 



\title{
CHAPTER 2
}

\author{
Effects of dry period length and dietary energy source on \\ inflammatory biomarkers and oxidative stress in dairy cows
}

\author{
N. Mayasari*†, J. Chen*, A. Ferrari ${ }^{\S}$, R. M. Bruckmaier", B. Kemp*, \\ H. K. Parmentier*, A.T.M. van Knegsel*, E. Trevisi ${ }^{\S}$ \\ *Adaptation Physiology Group, Department of Animal Science, Wageningen \\ University, P.O. Box 338, 6700 AH Wageningen, the Netherlands; 'Faculty of \\ Animal Husbandry, Universitas Padjadjaran, 45363, Bandung, Indonesia; \\ Veterinary Physiology, Vetsuisse Faculty, University of Bern, Bremgartenstrasse \\ 109a, CH-25 3012 Bern, Switzerland; 'Istituto di Zootecnica, Faculty of \\ Agriculture, Food and Environmental Sciences, Università Cattolica del Sacro \\ Cuore, 29122 Piacenza, Italy
}




\subsection{Abstract}

Negative energy balance (NEB) in dairy cows in early lactation has been associated with increased inflammation and oxidative stress in these cows. The objective of this study was to evaluate the effects of dry period length and dietary energy source on inflammatory biomarkers and oxidative stress in dairy cows. Holstein-Friesian dairy cows (60 primiparous and 107 multiparous) were assigned randomly to $3 \times 2$ factorial design with 3 dry period lengths $(0,30$ or $60 \mathrm{~d})$ and 2 early lactation rations (glucogenic or lipogenic). Cows were fed a glucogenic or lipogenic ration from $10 \mathrm{~d}$ before the expected calving date. Blood was collected in weeks $-3,-2,-1,1,2$ and 4 relative to calving. Dry period length affected inflammatory biomarkers and oxidative stress especially in week 1 and 2 after calving. Cows with a 0-d dry period had higher levels of ceruloplasmin, cholesterol, reactive oxygen metabolites (ROM), and tended to have higher haptoglobin levels compared with cows with a $30-d$ or a $60-d$ dry period. Cows with a 0-d dry period had a lower plasma paraoxonase and bilirubin in the first 2 weeks after calving and a lower liver functionality index (LFI) compared with cows with a 60-d dry period. Cows with parity $>3$ and fed a glucogenic ration had higher cholesterol levels compared with cows fed a lipogenic ration. No interaction between dry period length and ration was present for inflammatory biomarkers or oxidative stress variables. Plasma bilirubin levels for cows with a 0-d dry period were negatively related to EB and metabolic status in these cows. Moreover, occurrence of clinical health problems (fever, mastitis, metritis and retained placenta) was 41 percent, 27 percent and 30 percent for cows with $0-d, 30-d$ and 60-d dry period, respectively. High plasma levels of ceruloplasmin, cholesterol and ROM in cows with 0-d dry period were related to the occurrence of health problems in these cows. In conclusion, omitting the dry period increased levels of ceruloplasmin, cholesterol, ROM and decreased level of bilirubin and paraoxonase in plasma, independent of ration, compared with cows with a 60-d dry period. These contrasting effects of dry period length on inflammatory status could be explained in part by the improved EB and occurrence of health problems in these cows, but was not related to increased somatic cell count in cows with a 0-d dry period. Cows with a 0 -d dry period had better EB, but also had higher levels of oxidative stress compared with cows with a 60-d dry period. Moreover, occurrence of health problems did not differ between cows with different dry period lengths.

Key words: continuous milking, acute phase protein, oxidative stress, energy balance. 


\subsection{Introduction}

During the transition period, which lasts from 3 weeks before to 3 weeks after calving (Drackley, 1999), dairy cows experience negative energy balance (NEB) which is accompanied by metabolic disorders and by increased inflammation (Bionaz et al., 2007, Trevisi et al., 2012a), immunosuppression (Mallard et al., 1998) and oxidative stress (Sordillo et al., 2009). Pro-inflammatory cytokines are related to increased inflammation during NEB (Grimble, 1990, Ametaj et al., 2005) by stimulating hepatic synthesis of positive acute phase protein (APP), such as haptoglobin and ceruloplasmin, and impairing hepatic synthesis of negative APP such as albumin and cholesterol (Bionaz et al., 2007, LeBlanc, 2012). Cows with NEB and inflammation had a higher bilirubin in plasma due to impairment of hepatic function (Bertoni et al., 2008). Paraoxonase is part of an extensive antioxidative system (Turk et al., 2004) and is considered as a negative APP (James and Deakin, 2004). In the early postpartum period, a lower plasma paraoxonase activity is positively associated with lipid metabolic disorders. Negative energy balance and high plasma free fatty acid (FFA) levels contribute to the development of fatty liver, which is in turn a contributing factor to other health concerns (e.g. metritis and retained placenta; Kaneene et al., 1997) and periparturient immunosuppression in the postpartum period (Lacetera et al., 2005, Kehrli et al., 2006).

Shortening or omitting the dry period during early lactation in dairy cows has been shown to improve energy balance (EB) (Van Knegsel et al. 2014) and metabolic status (Rastani et al., 2005, Chen et al., 2015) of dairy cows in the subsequent lactation. However, earlier studies showed variable effects of dry period length on mammary health (Pezeshki et al., 2007, Watters et al., 2008, Mayasari et al., 2016). A shortened dry period (34 to $40 \mathrm{~d}$ ) compared with a conventional dry period ( 55 to $65 \mathrm{~d}$ ) did not result in differences in SCC (Gulay et al., 2003, Watters et al., 2008, Shoshani et al., 2014) or clinical mastitis (CM) (Enevoldsen and Sørensen, 1992, Watters et al., 2008, Shoshani et al., 2014). Other studies have shown that a shortened dry period was associated with a tendency for higher SCC (Rémond et al., 1997, Annen et al., 2004) or tendency for lower SCC (Rastani et al., 2005) compared with a conventional dry period. Some studies (Klusmeyer et al., 2009, Mayasari et al., 2016) concluded that omitting the dry period resulted in higher SCC values compared with cows with a 56-d dry period, but some studies showed no differences on SCC between cows with 0-d and 56-d dry period (Rastani et al., 2005, Kopf et al., 2014). Another study showed omitting the dry period had a tendency for higher SCC (Rémond et al., 1997) compared with a conventional dry period. To our knowledge, 
omitting the dry period did not affect CM (Rémond et al., 1997, Mayasari et al., 2016). The effects of shortening or omitting the dry period in dairy cows on inflammatory biomarkers, liver functionality (paraoxonase and bilirubin levels), oxidative stress [reactive oxygen metabolites (ROM) and ferric-reducing antioxidant power (FRAP) levels], and creatinine as markers for mobilization of body muscle have not been reported.

We can hypothesize that when EB is improved by shortening or omitting the dry period, the beneficial effects of other management strategies, such as feeding a more glucogenic ration to improve EB and metabolic health are reduced. Earlier, we reported that cows in the current experiment cows fed a glucogenic ration compared with a lipogenic ration had improved EB (Van Knegsel et al., 2014) and decreased plasma $\beta$-hydroxybutyrate (BHB) concentration (Chen et al., 2015a), independent of dry period lengths. In other studies, the reduced FFA and BHB concentrations were associated with increased cholesterol and reduced haptoglobin levels in plasma (Bionaz et al., 2007, Trevisi et al., 2012) and reduced plasma ROM levels (Bernabucci et al., 2005, Trevisi et al., 2009). Thus, we could expect that feeding a glucogenic ration would reduce inflammation and oxidative stress of cows with different dry period lengths.

Our hypothesis was that improving EB and metabolic status by omitting or shortening of the dry period would reduce the inflammatory response (i.e. higher levels of negative APP, lower levels of positive APP, and higher liver functionality) and oxidative stress (lower ROM and higher FRAP levels in plasma) during transition period. Moreover, if omitting the dry period resulted in increased SCC but no occurrence of $\mathrm{CM}$, inflammatory biomarkers and oxidative stress may not be affected. The objective of this study was to evaluate effects of dry period length and dietary energy source on inflammatory biomarkers and oxidative stress in plasma from dairy cows.

\subsection{Materials and Methods}

\subsubsection{Experimental Design and Animals}

The Institutional Animal Care and Use Committee of Wageningen University (Wageningen, the Netherlands) approved the experimental protocol (registration number 2010026). The experimental design, dry period length and dietary contrast were described by Van Knegsel et al. (2014). In summary, 167 Holstein-Friesian dairy (60 primiparous cows and 107 multiparous cows) were 
selected from the Dairy Campus research herd (WUR Livestock Research, Lelystad, the Netherlands), blocked according to parity, calving date, milk yield in previous lactation, and body condition score (BCS), and randomly assigned to treatments within blocks. In total, 28 blocks were used and each block consisted of 6 cows, 1 cow $/$ treatment $(28$ blocks $\times 6$ cows $=168$ cows; 1 cow was excluded because she received the wrong ration at drying off). Before the experiment began, all cows had SCC $<250,000$ cells $/ \mathrm{mL}$ at the last and second last monthly test-day recordings. Treatments consisted of 3 dry period lengths $(0,30$ or $60-\mathrm{d})$ and 2 early lactation rations (glucogenic or lipogenic) resulting in a $3 \times 2$ factorial design. Cows used in this study were clinically healthy at start of the experiment. Cows were housed in a freestall with slatted floor and cubicles, and milked twice daily $(0500$ and $1630 \mathrm{~h})$. The drying-off protocol was as follows: cows with a 30-d or a 60-d dry period received a far-off ration $7 \mathrm{~d}$ before drying-off, were milked once daily $4 \mathrm{~d}$ before drying-off, and all were treated with an intramammary antibiotic at drying off (Supermastidol; Virbac Animal Health, Barneveld, the Netherlands).

\subsubsection{Rations}

Ration composition was described earlier (Van Knegsel et al., 2014). Prepartum, cows with a 30-d and 60-d dry period received a dry cow ration, and cows with a 0 -d dry period received a lactating cow ration supporting $25 \mathrm{~kg}$ of milk yield per day. From $10 \mathrm{~d}$ before expected calving onwards, cows of all treatments were fed $1 \mathrm{~kg} / \mathrm{d}$ glucogenic or lipogenic concentrate, which was increased postcalving in steps of $0.5 \mathrm{~kg} / \mathrm{d}$ until the concentrate supply reached $8.5 \mathrm{~kg} / \mathrm{d}$. The main ingredient for the glucogenic concentrate was corn, the main ingredients for the lipogenic concentrate were sugar beet pulp, palm kernel, and rumen-protected palm oil. A computerized feeder located in the freestall provided experimental concentrates. Cows in the parlor received $1 \mathrm{~kg} / \mathrm{d}$ of standard lactation concentrate. Forage composition did not differ among rations and was supplied ad libitum and consisted prepartum of grass silage, corn silage, wheat straw, and a protein source (rapeseed meal or soybean meal) in a ratio of 39:25:25:11 (DM basis). Postpartum, forage consisted of grass silage, corn silage, straw, and a protein source (rapeseed meal or soybean meal) in a ratio of 51:34:2:13 (DM basis). Rations were isocaloric (net energy basis: Dutch net energy evaluation (VEM system; Van Es, 1975), and contained equal amounts of intestinal digestible protein and degraded protein balance (DVE/OEB system; Tamminga et al., 1994). Concentrate and forage were supplied separately. 


\subsubsection{Milk Yield and Composition, Energy Balance, Dry Matter Intake and Somatic Cell Count}

Milk sampling and EB calculation were described previously by Van Knegsel et al. (2014). In short, milk yield was recorded daily. Milk samples for fat, protein, lactose, and SCC analysis (ISO 9622, 2013 Qlip NV, Zutphen, the Netherlands) were collected 4 times per week (Tuesday afternoon, Wednesday morning, Wednesday afternoon, and Thursday morning). Dry matter intake was recorded weekly. Energy balance was calculated according to the VEM system (Van Es, 1975, CVB, 2005) as the difference between VEM supplied with feed and VEM required for maintenance and milk production. Animal maintenance requirements are $42.4 \mathrm{VEM} / \mathrm{kg} 0.75 \cdot \mathrm{d}(1,000 \mathrm{VEM}=6.9 \mathrm{MJ}$ of net energy). The VEM required for milk production is $442 \mathrm{VEM} / \mathrm{kg}$ of fat and protein-corrected milk (Van Es, 1975).

\subsubsection{Blood Sampling}

Blood sampling was described previously by Chen et al. (2015). In short, blood samples from 92 cows were taken weekly from the tail vein at $3 \mathrm{~h}$ before the morning feeding from weeks -3 to 8 relative to calving date. Blood was collected in evacuated tubes (Vacuette, Greiner BioOne, Kremsmunster, Austria) containing $\mathrm{NaF}$ for glucose, EDTA for insulin, FFA, BHB, and urea analysis, or litiumheparin for IGF-I, haptoglobin, ceruloplasmin, cholesterol, albumin, bilirubin, paraoxonase, ROM, FRAP, and creatinine. Samples were kept cold on ice for a maximum of $2 \mathrm{~h}$ until they were centrifuged at $3,000 \times \mathrm{g}$ for $15 \mathrm{~min}$ at $4^{\circ} \mathrm{C}$. Plasma was decanted, aliquoted, and frozen at $-20^{\circ} \mathrm{C}$ until analysis.

\subsubsection{Laboratory Analysis}

Plasma samples for metabolite and hormones determination were analyzed at the Veterinary Physiology group of the Vetsuisse Faculty, University of Bern (Bern, Switzerland). Concentrations of glucose and urea were measured using commercial kits no. 61269 and no. 61974 from BioMérieux (Marcy l'Etoile, France), as described previously (Graber et al., 2012). Concentrations of FFA and BHB were measured enzymatically using kit no. 994-75409 from Wako Chemicals (Neuss, Germany) and kit no. RB1007 from Randox Laboratories (Ibach, Switzerland), as described previously (Graber et al., 2012). Insulin-like growth factor-1 and insulin were measured using RIA, as described previously (Vicari et al., 2008). 
Inflammatory biomarkers and oxidative stress were measured at the Istituto di Zootecnica of the Università Cattolica del Sacro Cuore (Piacenza, Italy), following the procedures described previously by Bionaz et al. (2007), Calamari et al. (2016) and Jacometo et al. (2015) using a clinical auto-analyzer (ILAB 650, Instrumentation Laboratory, Lexington, MA). In short, total cholesterol (catalog no. 0018250540), albumin (catalog no. 0018250040), total bilirubin (catalog no. 0018254640), and creatinine (catalog no. 0018255540) were measured using the IL Test purchased from Instrumentation Laboratory Spa (Werfen Co., Milan, Italy). The haptoglobin was determined with the method described by Skinner et al. (1991) and Owen et al. (1960), adapted to ILAB 650 condition. The method based on peroxidase activity of methaemoglobin-haptoglobin complex measured by the rate of oxidation of guaiacol (hydrogen donor) in the presence of hydrogen peroxide (oxidizing substrate). The ceruloplasmin was determined with the method described by Sunderman and Nomoto (1970), adapted to ILAB 650 conditions. The test is based on measurement of the colour which originates from the oxidation of the p-phenylenediamine dihydrochloride induced by the ceruloplasmin. The ROM was measured using commercial kits (kit d-ROMs-test cod. MC003, Diacron International s.r.1., Grosseto, Italy) adapted to the ILAB 650 conditions. Antioxidant potential was assessed as ferric reducing antioxidant power (FRAP) using the colorimetric method of Benzie and Strain (1996). Plasma paraoxonase activity was measured by adapting the method of Ferré et al. (2002) to the ILAB 650 conditions.

\subsubsection{Statistical Analysis}

The MIXED procedure of SAS (version 9.2, SAS Institute Inc., Cary, NC, Littell et al., 1996) for repeated measures analysis was used to analyze the effects of dry period length and ration on inflammatory biomarkers and oxidative stress. The fixed effects were dry period length $(0,30$ or $60 \mathrm{~d})$, ration (glucogenic or lipogenic), parity (2, 3 or $>3)$, week $(-3,-2,-1,1,2$ and 4 relative to calving), and their 2-way interactions (model 1). Cow was considered as the repeated subject. All variables approximated normality of residuals by examining whether skewness and kurtosis were in a range of -2 to 2 . Four covariance structures were tested: compound symmetry, heterogeneous compound symmetry, first-order autoregressive [AR (1)], and unstructured covariance structure. Covariance structure that resulted in the smallest Akaike information criterion was used. For comparison of dry period length effects, $P$-values are presented after a TukeyKramer adjustment. Preliminary analysis showed that effects of dry period length 
were more pronounced in the first 2 weeks after calving, therefore data were analyzed for total transition period (-3, -2, -1, 1, 2 and 4 relative to calving) and specifically for the first 2 weeks after calving, separately. The [AR (1)] covariate structure covariance structure was the best fit and was used to account for withincow variation. Preliminary result showed that the levels of bilirubin for all samples was relatively low compared earlier studies (Bionaz et al., 2007, Bertoni et al., 2008, Trevisi et al., 2012a). The animal experiment was performed from 2010 until 2013, and the prolonged storage condition of the plasma samples may have affected the level of bilirubin. However, in the current study the dynamic of bilirubin levels by week around calving followed the typical pattern of change observed in the peripartum period in earlier studies (Ametaj et al., 2005, Bionaz et al., 2007, Trevisi et al., 2012a). All the plasma parameters have been setted with calibration curves, and data were standardized using quality control standards (internal and purchased by Instrumentation Laboratory, Lexington, MA).

Liver functionality index (LFI) was calculated according to Trevisi et al. (2012a). Albumin, cholesterol, and bilirubin data were used to calculate the LFI. The LFI calculation is carried out in 2 steps; the first step considers the values of the 3 parameters observed in week 1 and their changes between week 1 and 4 . In the second step, these partial indexes were standardized according to average values observed in "healthy" cows. The higher value of LFI, the better adaptation of the cows to transition period; lower value of LFI indicates the presence of inflammation and metabolic disorder (Trevisi et al., 2016). The LFI was calculated according to the following formula:

$$
\begin{aligned}
& \mathrm{LFI}=[(\text { albumin index }-17.71) / 1.08+(\text { cholesterol index- } \\
& 2.57) / 0.43-(\text { bilirubin index }-6.08) / 2.17)]
\end{aligned}
$$

These partial indices were categorized to 4 quartiles of LFI [low (LO), intermediate low (IN-LO), intermediate up (IN-UP) and high (UP)]. To determine the 4 quartiles, we ranked cows by LFI value from the smallest to the highest, and then we divided cows into 4 groups with equal number of cows in each. The high LFI value was taken to define "healthy" and "well adapted" cows and low values were associated with a large inflammatory response and clinical health problem. Clinical health problems were defined as occurrence of metritis, fever, mastitis or retained placenta per cow per week, these are diseases that cause an inflammatory response. Healthy cows were defined as cows not treated for disease. The frequency of clinical health problem was determined in the 4 quartiles of LFI from week 1 to 4 postcalving. Statistical analysis for LFI was performed in the first 4 
weeks after calving with model 1 . Because there was only one LFI value per cow, week was excluded from the model. The AR (1) covariance structure was the best fit and was used to account for within-cow variation. Statistical analysis for milk yield, EB, SCC, plasma metabolites and hormones were performed in the first 2 weeks after calving with model 1 . Cow was considered as the repeated subject. The AR (1) covariate structure was the best fit, and was used to account for within-cow variation. For comparison of dry period length effects $P$-values are presented after a Tukey-Kramer adjustment. The result for milk yield, EB, SCC, plasma metabolites and hormones in the first 2 weeks after calving are presented in the Appendix Table 2. A1.

To analyze whether EB, SCC or clinical health problems (yes or no) explained the differences in inflammatory biomarkers and oxidative stress between different dry period lengths in the first 2 weeks after calving were included as fixed effect in model 1 in separate analyses. Cow was considered as the repeated subject. The AR (1) covariate structure was the best fit, and was used to account for withincow variation. For comparison of dry period length effects $P$-values are presented after a Tukey-Kramer adjustment. Values are presented as least squares means (LSM) with their pooled standard errors of the mean (SEM), unless otherwise stated.

\subsection{Results}

\subsubsection{Effects of Dry Period Length and Ration on Inflammatory Biomarkers in Plasma of Cows}

During transition period from weeks -3 to 4 relative to calving, cows with a 0 -d dry period had higher ceruloplasmin and cholesterol levels in plasma compared with cows with a $30-\mathrm{d}$ or a $60-\mathrm{d}$ dry period (Table 2.1). Cows with a 60-d dry period had higher bilirubin levels compared with cows with a 30-d dry period. Plasma bilirubin levels did not differ among cows with a 0 -d dry period and those with a $30-\mathrm{d}$ or $60-\mathrm{d}$ dry period. The effects of dry period length on inflammatory biomarkers were more pronounced in the first 2 weeks after calving (Figure 2.1). In the first 2 weeks after calving, cows with a 0-d dry period had higher levels of ceruloplasmin, cholesterol and tended to have higher haptoglobin levels in plasma compared with cows with a 30-d or a 60-d dry period (Table 2.2). In addition, in the first 2 weeks after calving, cows with a 0-d dry period had lower plasma paraoxonase and bilirubin levels compared with cows with a 60-d dry period. From 
weeks -3 to 4 relative to calving, cows with parity $\geq 3$ had higher ceruloplasmin and lower albumin levels in plasma compared with cows with parity 2 (1.7 vs. 1.8 vs. $1.8 \pm 0.1 \mu \mathrm{moL} / \mathrm{L}$ and 37.8 vs. 36.9 vs. $36.8 \pm 0.2 \mathrm{~g} / \mathrm{L}$ for parity 2 vs. 3 vs. $>3$ for ceruloplasmin and albumin, respectively). From weeks -3 to 4 relative to calving, we detected an interaction between ration and parity for cholesterol. Cows with parity $>3$ fed a glucogenic ration had higher cholesterol in plasma compared with cows fed a lipogenic ration. In contrast, cows with parity 2 fed a lipogenic ration had higher cholesterol in plasma compared with cows fed a glucogenic ration.

\subsubsection{Effects of Dry Period Length and Ration on Liver Functionality Index in Plasma of Cows}

Cows with a 0-d dry period had lower LFI compared with cows with a 30 or 60-d dry period (Table 2.1). Significant interactions between dry period $\times$ ration and dry period $\times$ parity were found for LFI. We ranked the cows by LFI and divided them into 4 groups with an equal number of cows, resulting in the 4 quartiles of LFI [low (-1.70 to 0.70$)$, intermediate-low ( 0.86 to 2.32 ), intermediatehigh (2.36 to 3.34), and high (3.36 to 12.00)]. Cows with low LFI had a higher frequency of clinical health problem (mastitis, metritis, retained placenta and fever, 17 occurrences) compared with intermediate-low, intermediate-high and high LFI (7 vs. 1 vs. 8 occurrences, respectively, $P<0.01$ ).

\subsubsection{Effects of Dry Period Length and Ration on Oxidative Stress in Plasma of Cows}

Cows with a 0-d dry period had higher level of ROM in plasma compared with cows with a 30-d or a 60-d dry period (Table 2.1). The contrasts between dry period length for ROM levels were more pronounced in the first 2 weeks after calving. We detected no effect of dry period length on FRAP levels in plasma of cows but did detect an interaction between dry period length and parity for FRAP. Cows with parity $>3$ cows had lower FRAP compared with cows with parity $\leq 3$ (171.6 vs. 171.2 vs. $158.9 \pm 4.0 \mu \mathrm{mol} / \mathrm{L}$ for parity 2 vs. 3 vs. $>3$ ) in the first 2 weeks after calving. 


\subsubsection{Effects of Dry Period Length on Creatinine, Milk Yield, DMI, EB, SCC, Plasma Metabolites and Hormones}

There was no effect of dry period length or ration on creatinine levels in plasma of cows (Table 2.1 and 2.2). However, there was an interaction between dry period lengths and parity for creatinine. Cows with parity $\geq 3$ had higher creatinine in plasma when they had a 0-d dry period compared with cows with parity 2 . Contrary, cows with parity $>3$ had lower creatinine in plasma when they had a 30$\mathrm{d}$ or a 60 -d dry period compared with cows with parity 2 and 3 . In the first 2 weeks after calving, cows with a 0 -d dry period produced less milk, had better EB, higher SCC in milk, lower FFA, higher IGF-I, higher glucose and higher insulin concentrations in plasma compared with cows with a $30-\mathrm{d}$ or $60-\mathrm{d}$ dry period (see Table 2.A1). In addition, DMI did not differ among dry period lengths treatments in the first 2 weeks after calving $(P=0.95)$.

\subsubsection{Relationship between Energy Balance and Somatic Cell Count with Inflammatory Biomarkers and Oxidative Stress}

When EB was included as a covariate, low bilirubin levels were related to better EB in the first 2 weeks after calving. Bilirubin levels between dry period length were similar and not significant (Table 2.3).

Level of SCC was not related to levels of inflammatory biomarkers and oxidative stress, except for ceruloplasmin. The relation of SCC with ceruloplasmin was dependent on parity (Table 2.4).

\subsubsection{Relationship of Clinical Health Problems with Inflammatory Biomarkers and Oxidative Stress}

Occurrence of clinical health problems was related to high ceruloplasmin, low albumin, low bilirubin, and high ROM, and tended to be related to high levels of haptoglobin in plasma (Table 2.5). The contrast between dry period length remained whether excluding or including clinical health problems in the model. In the first 2 weeks after calving, occurrence of clinical health problems related to inflammation (fever, mastitis, metritis and retained placenta) was 41, 27 and 30 percent for cows with $0-\mathrm{d}, 30-\mathrm{d}$ and $60-\mathrm{d}$ dry period, respectively (Table 2.6). Dry period length did not affect occurrence of clinical health problems $(P=0.23)$. 


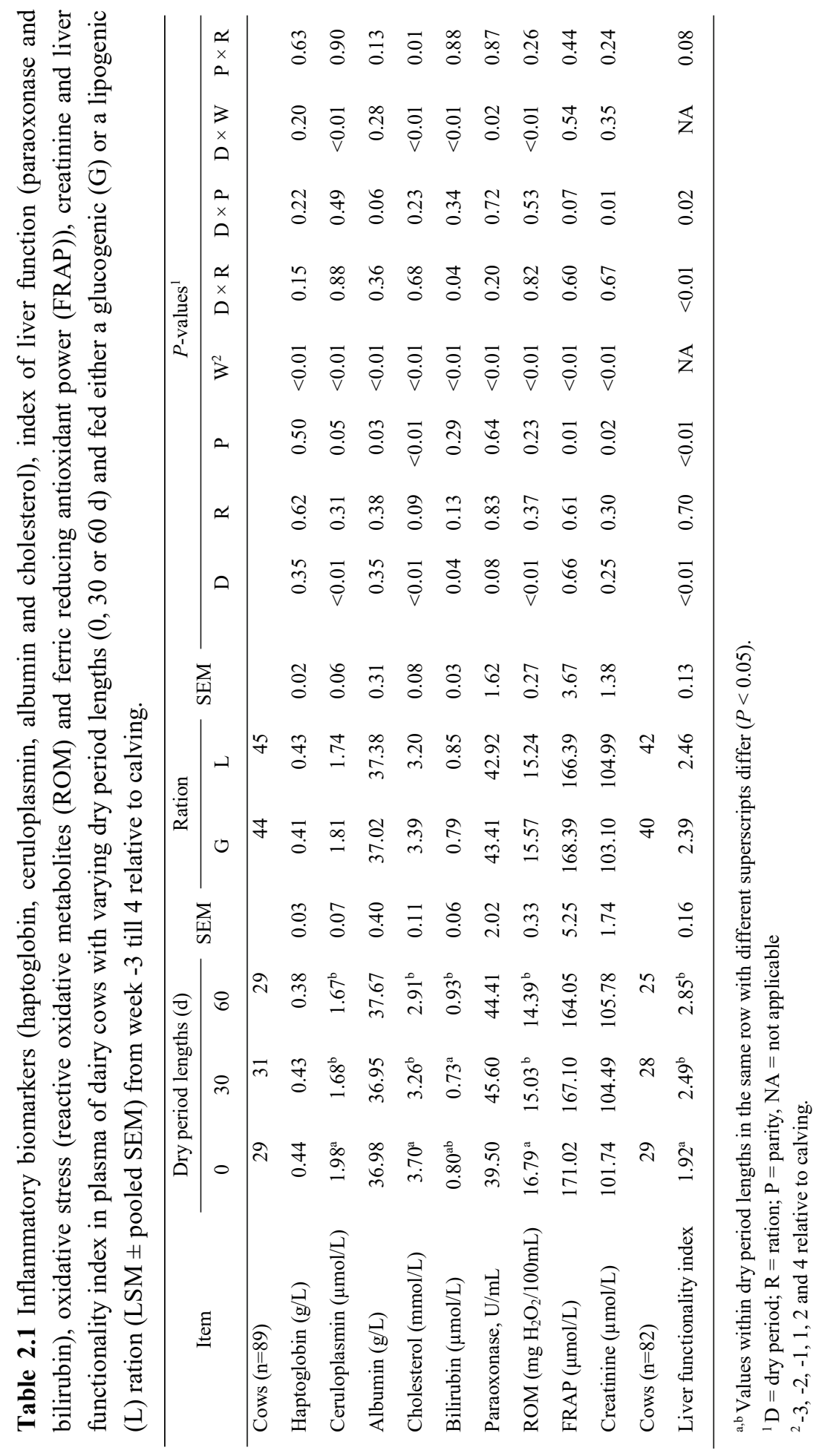



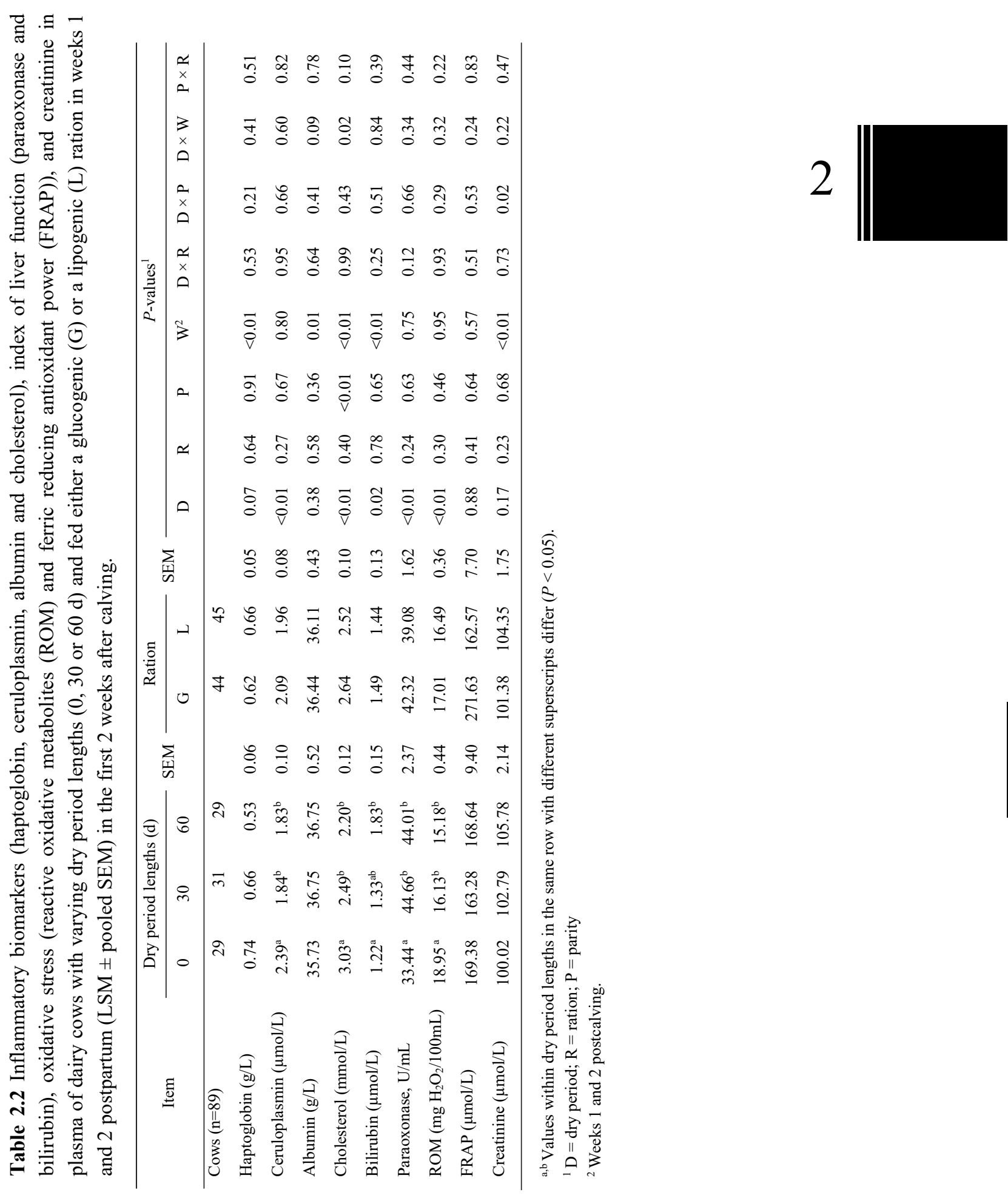


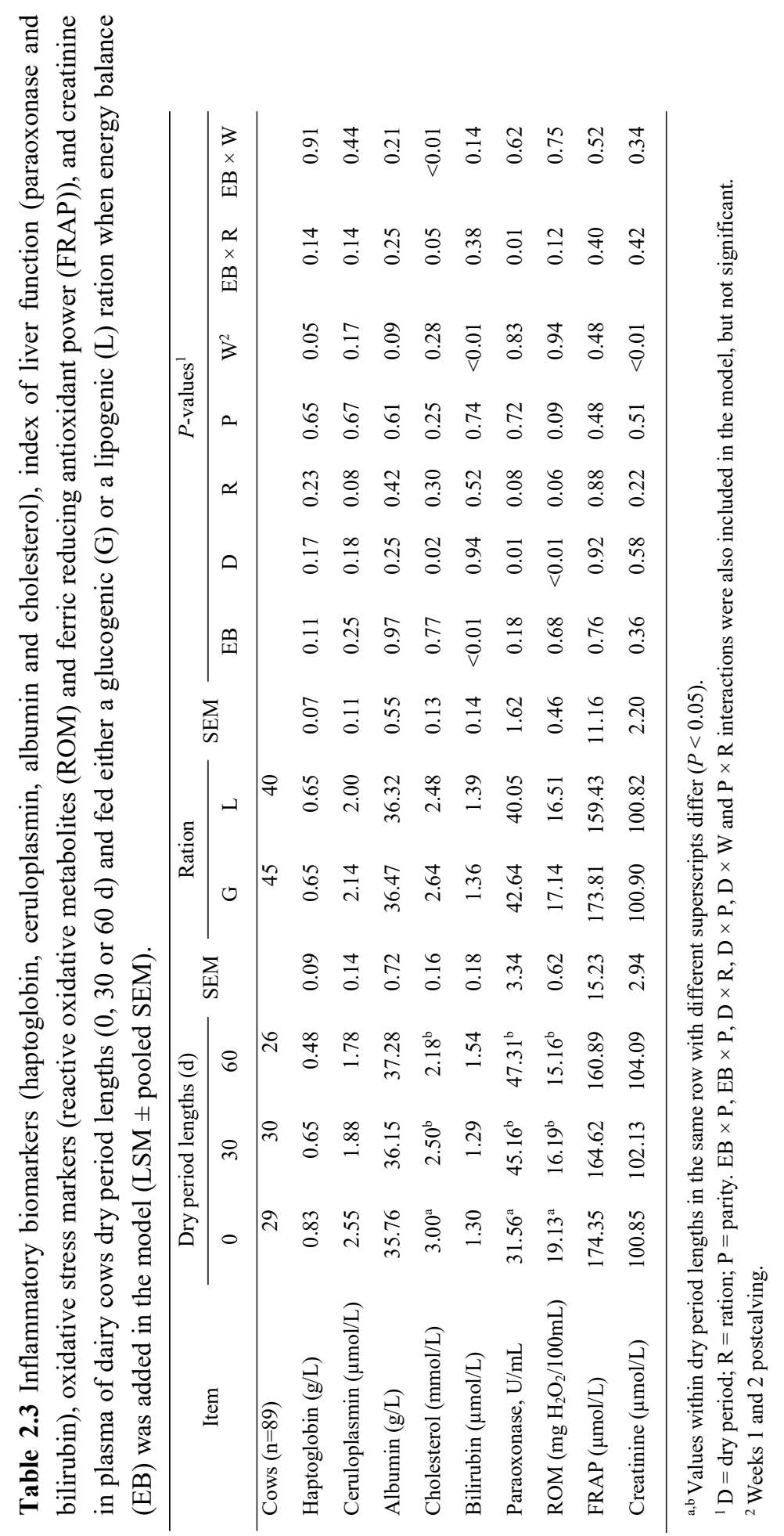




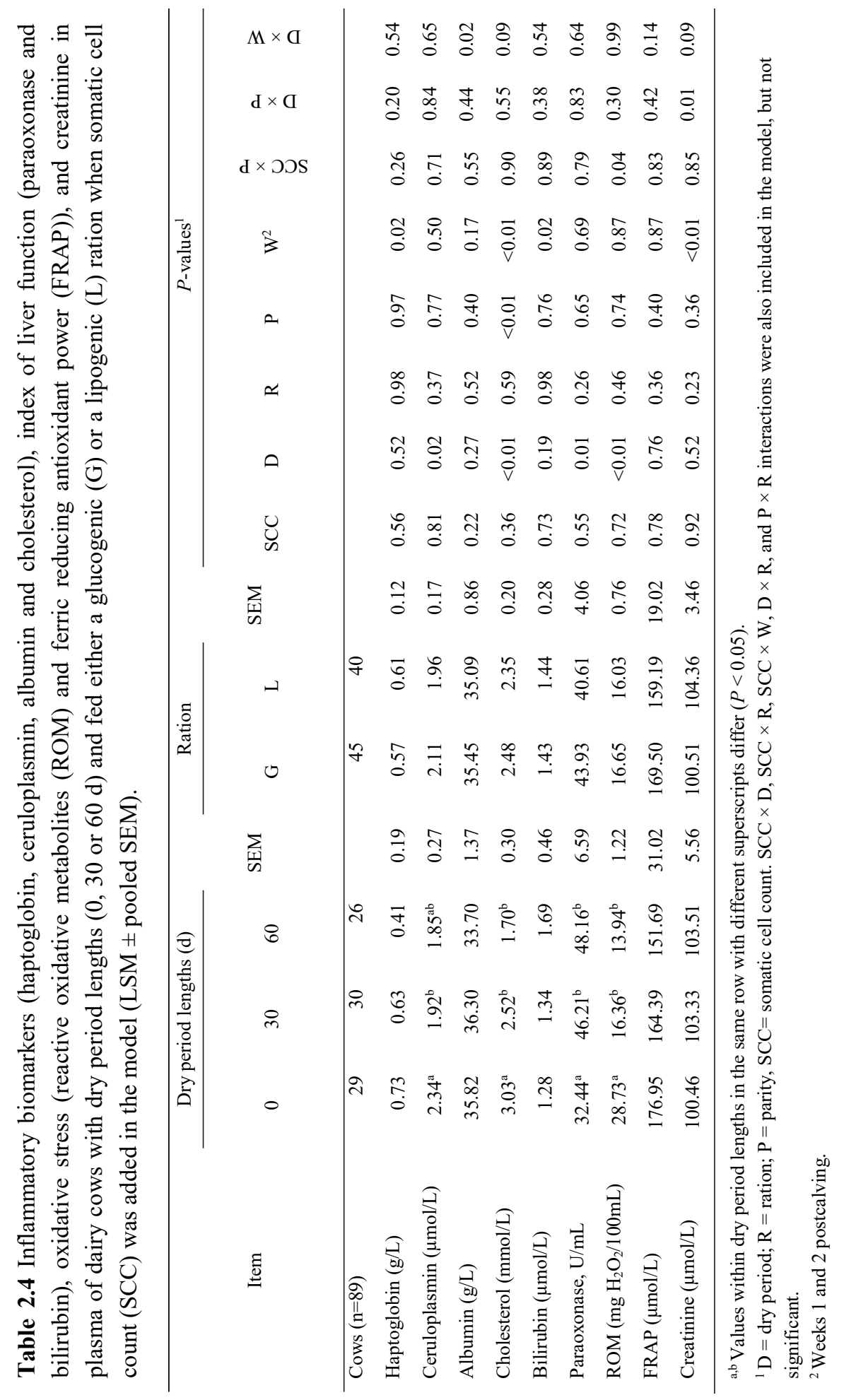




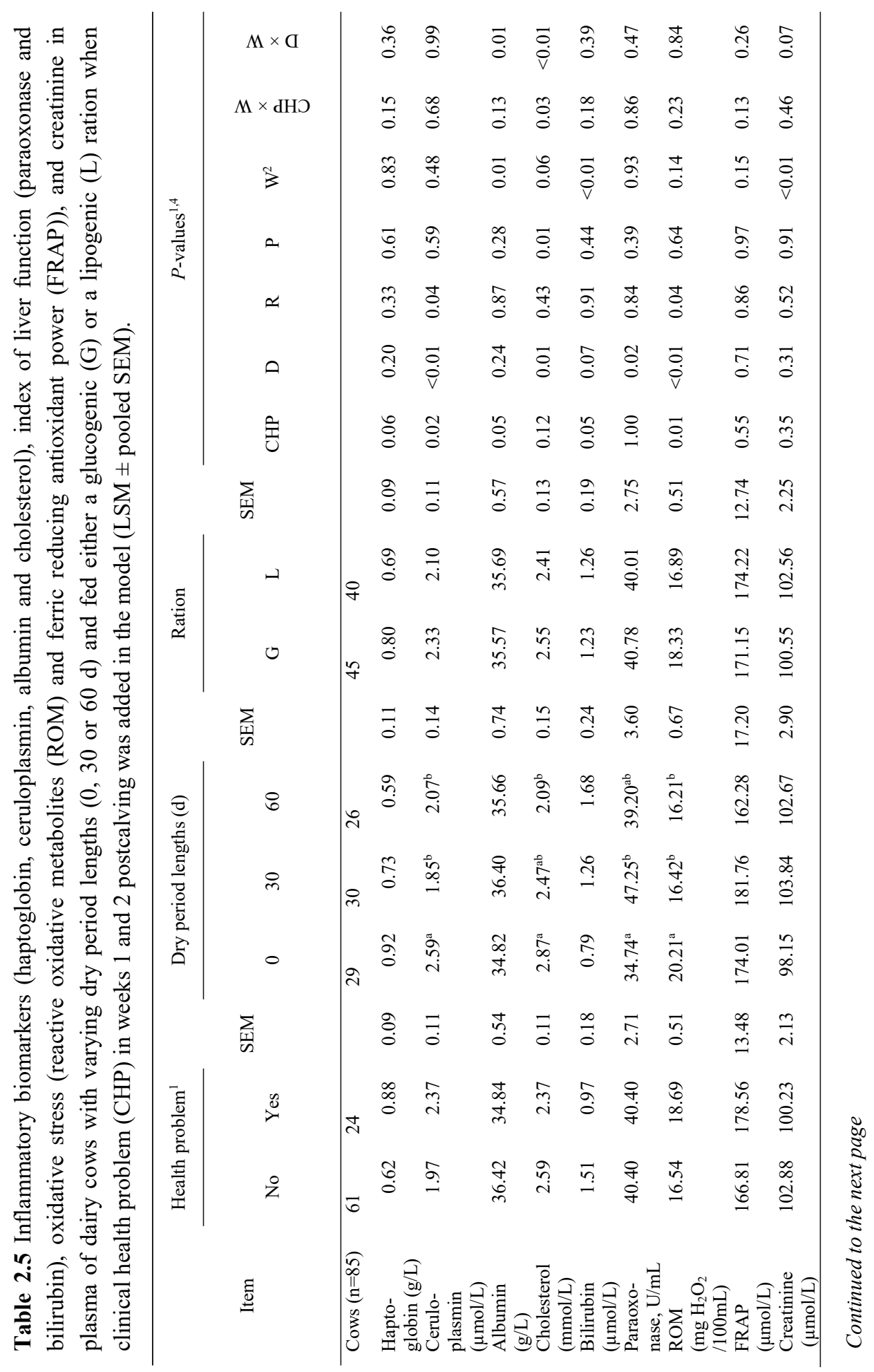


Table 2.5 continued

${ }^{\mathrm{a}, \mathrm{b}}$ Values within dry period lengths in the same row with different superscripts differ $(P<0.05)$.

${ }^{1} \mathrm{D}=$ dry period, $\mathrm{R}=$ ration, $\mathrm{P}=$ parity, $\mathrm{CHP}=$ clinical health problem (metritis, mastitis, retained placenta, or fever). CHP $\times \mathrm{D}, \mathrm{CHP} \times \mathrm{R}, \mathrm{CHP} \times \mathrm{P}, \mathrm{D} \times \mathrm{R}, \mathrm{D} \times \mathrm{P}$, and $\mathrm{P} \times \mathrm{R}$ interactions were also included in the model, but not significant

${ }^{2}$ Weeks 1 and 2 postcalving.

Table 2.6 Distribution of cows with different clinical health problems in weeks 1 and 2 postcalving.

\begin{tabular}{cccccccc}
\hline $\begin{array}{c}\text { Dry period } \\
\text { lengths }\end{array}$ & $\mathrm{n}$ & Fever & Mastitis & Metritis & $\begin{array}{c}\text { Retained } \\
\text { Placenta }\end{array}$ & Total & Percentages \\
\hline $0 \mathrm{~d}$ & 56 & 2 & 8 & 2 & 11 & 23 & $41 \%$ \\
$30 \mathrm{~d}$ & 55 & 2 & 5 & 1 & 7 & 15 & $27 \%$ \\
$60 \mathrm{~d}$ & 56 & 4 & 2 & 1 & 10 & 17 & $30 \%$ \\
\hline
\end{tabular}

\subsection{Discussion}

\subsubsection{Effect of Dry Period Length on Inflammatory Biomarkers}

In the current study, cows with a 0 -d dry period, compared with a $30-d$ or a 60-d dry period, had higher cholesterol, ceruloplasmin and tended to have higher haptoglobin levels in plasma especially in the first 2 weeks after caving, independent of dietary treatment. Previous studies have shown that a quicker increase in cholesterol (Kaneene et al., 1997, Trevisi et al., 2009) has been associated with a better EB and improved metabolic status in dairy cows in early lactation. In another study, the reduced levels of haptoglobin and ceruloplasmin were associated with better EB (Bionaz et al., 2007). The increase of haptoglobin was earlier related to high production of liver macrophages (known as Kupffer cells) during inflammation (Ametaj et al., 2005, Trebicka et al., 2011). The increase of ceruloplasmin was associated with health problems in cows in early lactation (Conner et al., 1988, Chassagne et al., 1998, Sheldon et al., 2001). 

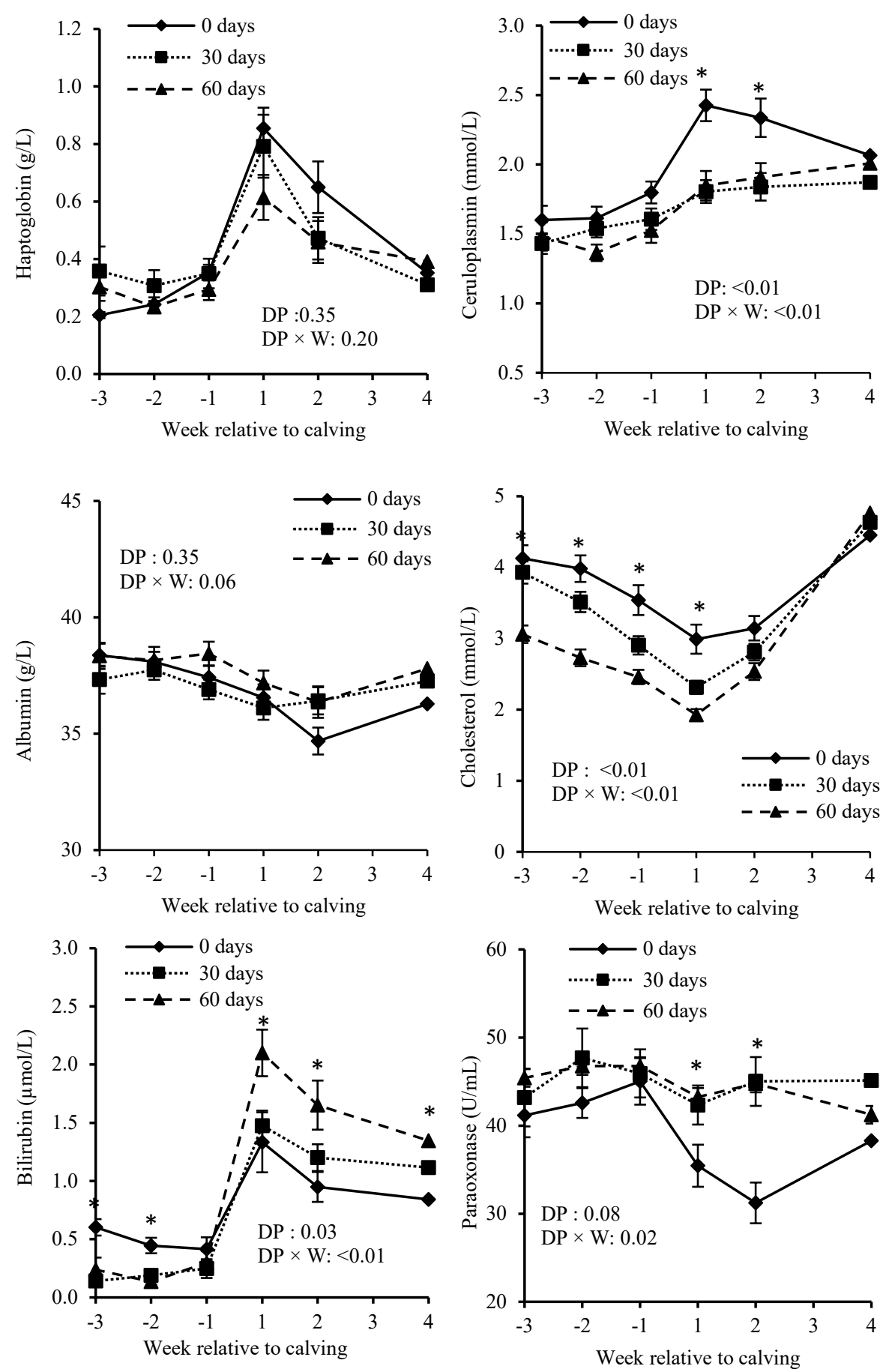

Continued to the next page 

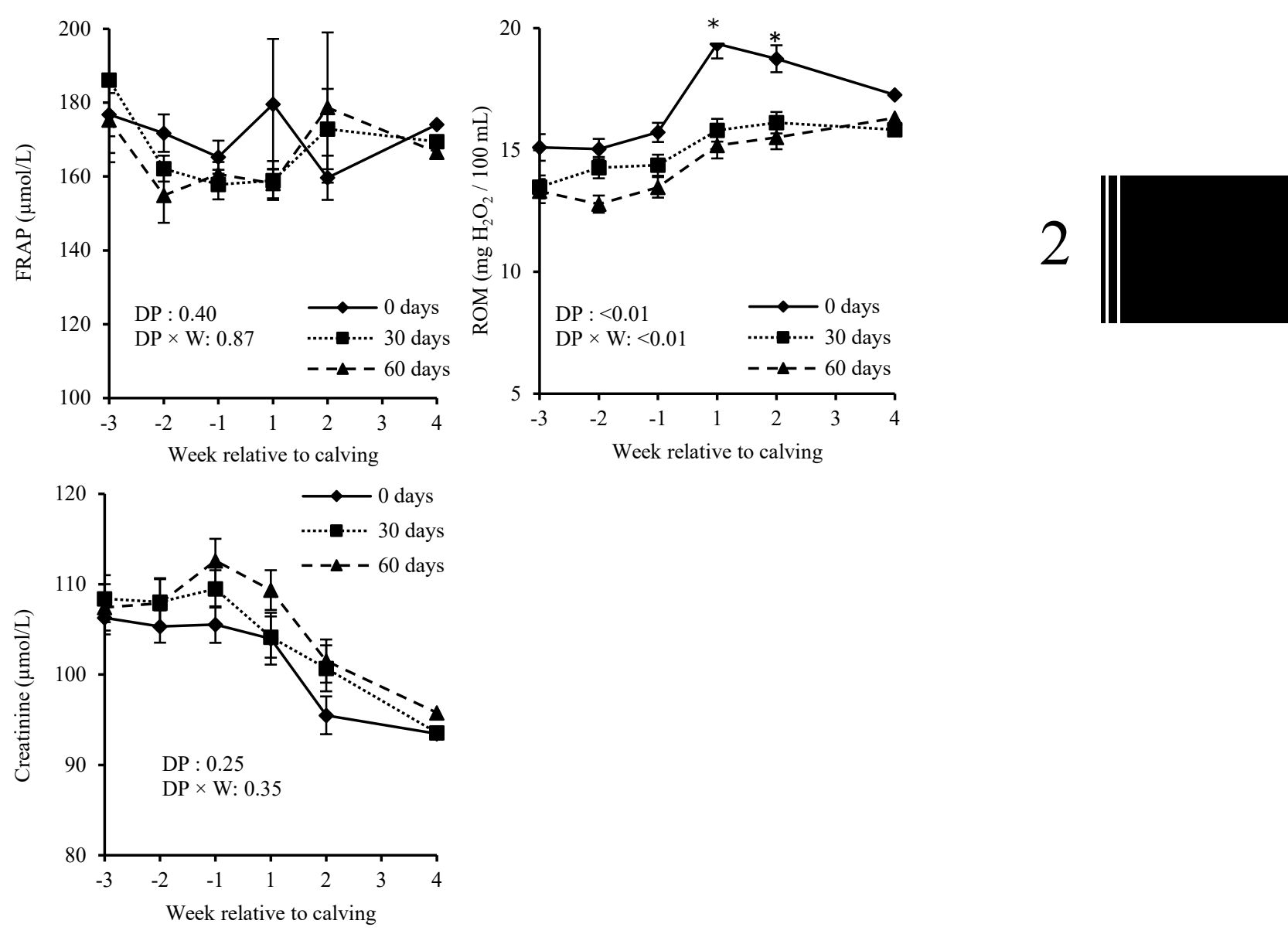

Figure 2.1 Inflammatory biomarkers (haptoglobin, ceruloplasmin, albumin and cholesterol), index of liver function (paraoxonase and bilirubin), oxidative stress markers [reactive oxidative metabolites (ROM) and ferric reducing antioxidant power of plasma (FRAP)], and creatinine in plasma of dairy cows per dry period lengths $(0,30$ or 60 -d) per week (Mean \pm SEM). $P$-values of dry period (DP) and interaction between DP $\times$ week (W) for each parameter are shown. Asterisks indicate significant $(P<0.05)$ differences between dry period lengths within week. 


\subsubsection{Effect of Dry Period Length on Liver Functionality}

In the current study, cows with a 0-d dry period had lower levels of bilirubin and paraoxonase in plasma compared with cows with a 60-d dry period, especially in the first 2 weeks after calving. Bilirubin and paraoxonase are commonly used biomarkers for liver functionality status around calving (Bertoni et al., 2008, Bertoni and Trevisi, 2013). Previous studies have shown that reduced bilirubin levels indicated better clearance of secretory enzymes in the liver and are associated with a better EB and improved metabolic status in dairy cows in early lactation (Assenat et al., 2004, Bertoni et al., 2008). In the current experiment, omitting the dry period reduced milk yield, improved the EB, reduced total milk and fat- and protein-corrected milk yields, and yield of lactose, fat, and protein yields but did not affect DMI, compared with cows with a 60 dry period (Van Knegsel et al., 2014), and not in the first weeks of lactation which was the focus of the current study (Table 2.A1). In the current study, DMI was negatively related to bilirubin levels $(r=-0.35, P<0.01)$ while milk yield was positively related to bilirubin levels $(r=0.22, P<0.01)$.

Paraoxonase, known as a liver protein with hydrolase activity is considered as a marker of liver activity (Bionaz et al., 2007) and known as a negative APP (James and Deakin, 2004). Previous studies showed that a reduced paraoxonase levels in plasma were associated with lipid metabolic disorders (Aviram and Rosenblat, 2004, Turk et al., 2004) and chronic liver damage in dairy cows (Ferré et al., 2002). In the current study, the reduced bilirubin levels in plasma after a 0 -d dry period might be associated with better functionality of the hepatocytes related to better EB. Moreover, the decreased paraoxonase was not associated with EB. Previously, reduced level of paraoxonase in plasma was associated with increased level of bilirubin in plasma (Bionaz et al., 2007, Trevisi et al., 2012b). However, in the current study the reduced paraoxonase levels in plasma of cows with 0 -d dry period was accompanied by an increased haptoglobin levels $(r=-0.28, P=0.03)$, which could be related to a more severe inflammatory condition (Bionaz et al., 2007, Bertoni and Trevisi, 2013) of these cows in the first 2 weeks after calving. Our study indicated that reduced paraoxonase was related to inflammation and low liver functionality of dairy cows with a 0 -d dry period at least in the first 2 weeks after calving.

Results of this study indicate that cows with a 0-d dry period had better clearance of waste products in the liver as shown by a reduced level of bilirubin in plasma immediately after calving. However, during the 4 weeks after calving, the 
levels of bilirubin, albumin, and cholesterol in plasma of cows with a 0-d dry period resulted in lower LFI compared with cows with 30-d or 60-d dry period. The LFI defines a good liver functionality when the levels of bilirubin decrease, and cholesterol and albumin increase between week 1 and 4 in lactation (Trevisi et al., 2012a). When liver functionality, according to LFI, is poor, these levels stabilize during weeks 1 to 4 in lactation. Trevisi et al. (2012a) suggested that low LFI indicates lower liver function immediately after calving because of severe inflammation and cows have problems adapting to their inflammatory challenges have a low response of negative APP in the first month of lactation. In the current study, cows with a 0 -d dry period had high cholesterol both at calving and after calving (but with a slight increase in the first month of lactation), compared with cows with a 60-d dry period, which showed a marked increase from week 1 to 4 . In addition, cows with a 0 -d dry period had a low bilirubin at calving and a limited decrease after calving. Thus, levels of cholesterol are high but stable, levels of bilirubin are low and stable for cows with a 0-d dry period, whereas levels of albumin showed a reduction after calving. This might imply that indeed recovery of the liver is poor for cows with a 0-d dry period between week 1 and 4 of lactation, which is partly related to the high liver status at calving.

\subsubsection{Effect of Dry Period Length on Oxidative Stress}

In the first 2 weeks after calving, omitting the dry period increased ROM levels in plasma compared with a 60-d dry period. High ROM levels indicate conditions of high oxidative stress (Esposito et al., 2014), which is associated with severe NEB (Bernabucci et al., 2005, Pedernera et al., 2010). In the current study, the better EB, due to lower milk yield, in cows with a 0-d dry period was not associated with increased ROM concentration. Osorio et al. (2014) suggested that oxidative stress is triggered by the imbalance between the production of ROM and the neutralizing capacity of antioxidant mechanisms (including production of FRAP) in tissues and in blood. A previous study showed that increased levels of ROM in plasma were associated with reduced levels of paraoxonase as part of a huge anti-oxidative system in plasma (Trevisi et al., 2012b). In the current study, omitting the dry period compared with a 30-d or 60-d dry period increased levels of ROM and reduced paraoxonase levels without affecting FRAP levels. Our results indicate that the increased of ROM levels in cows with a 0-d dry period might be related to the reduced paraoxonase levels $(r=-0.31, P=0.02)$, which indicated a more severe oxidative stress, compared with cows with a 60 -d dry period. 
In the current study, cows with a 0-d dry period increased pro- and antiinflammatory markers, oxidative stress, and lower liver functionality compared with cows with 60-d dry period. Inflammation and oxidative stress are associated with reduced mammary health (Pyörälä, 2003), NEB, and the occurrence of clinical health problems (Drackley, 1999, Trevisi et al., 2014). To our knowledge, only one study (Trevisi et al., 2010) has reported the relationship between inflammatory biomarkers and SCC or health status in cows with different dry period lengths from 47 to $71 \mathrm{~d}$. However, a research about the relationship between SCC, EB, or clinical health problems and inflammatory biomarkers or oxidative stress in cows with different dry period length $(0,30$, or $60-\mathrm{d})$ is lacking. It is not clear whether the increase of pro-inflammatory biomarkers and oxidative stress in the current study was directly due to dry period length effects, or related to differences in SCC, EB or clinical health problems.

\subsubsection{Effect of Somatic Cell Count on Inflammatory Biomarkers and Oxidative Stress}

In the current study, the effect of dry period length on inflammatory biomarkers and oxidative stress variables could not be explained by the effect of dry period length on SCC. A previous study showed that mammary gland cell differentiation and proliferation, and oxidative stress might causes inflammation during transition period (Trevisi et al., 2010). Subclinical mastitis, defined as an elevated SCC without clinical signs, was associated with increased levels of haptoglobin in plasma (Safi et al., 2009). Occurrence of clinical mastitis was associated with increased haptoglobin levels (Pyörälä, 2003) and bilirubin levels (Minuti et al., 2015) and decreased paraoxonase levels (Turk et al., 2012). As earlier reported, in the current experiment, omitting the dry period increased SCC in milk in the subsequent lactation but did not affect the occurrence of CM compared with cows with a 30-d or a 60-d dry period (Mayasari et al., 2016). This is in line with the present results that high SCC in cows with 0-d dry period was not associated with inflammatory biomarkers and oxidative stress.

\subsubsection{Effect of Energy Balance on Inflammatory Biomarkers and Oxidative Stress}

In the current study, low plasma bilirubin levels were associated with better EB, independent of dry period length. In addition, DMI was negatively related to haptoglobin levels $(r=-0.38, P<0.01)$, cholesterol levels $(r=-0.26, P<$ 
$0.01)$ and bilirubin levels $(r=-0.35, P<0.01)$. Milk yield was positively related to bilirubin levels $(r=0.22, P<0.01)$, independent of dry period length. Previous studies showed that NEB in dairy cows is related to fatty liver, potentially affecting liver function (Ametaj et al., 2005, Bertoni et al., 2008). Bilirubin is commonly used as a biomarker for liver status around calving (Bionaz et al., 2007, Bertoni et al., 2008). Hence, it can be suggested that the effect of dry period length on bilirubin levels was associated with alterations in EB and metabolic status in the first 2 weeks after calving. Moreover, liver functionality was associated with fatty acid uptake and secretion of cholesterol from triglycerides (Bell, 1995). In contrast, the lower bilirubin levels in cows with a 0 -d dry period immediately after calving suggests a better clearance in the liver.

\subsubsection{Effect of Clinical Health Problems on Inflammatory Biomarkers and Oxidative Stress}

In the current study, the occurrence of clinical health problems was related to high levels of ceruloplasmin, low albumin levels, low bilirubin levels, high ROM levels, and a tendency for high haptoglobin levels in plasma, independent of dry period length. In addition, the levels of ceruloplasmin and ROM before calving are higher for cows with clinical health problem. This is in line with previous studies that the occurrence of clinical health problems was associated with consequences of severe or prolonged inflammations before calving (Trevisi et al., 2011, Trevisi et al., 2012a) and oxidative stress (Trevisi et al., 2010). Our results indicate that the dry period length may not directly be a causative factor for inflammation and stress. The changes in inflammatory biomarkers after calving are related to the occurrence of health problems, but many of these begin before calving and several remain subclinical.

\subsubsection{Effect of Ration and Parity on Inflammatory Biomarkers and Oxidative Stress}

Parity influenced the levels of ceruloplasmin, albumin, cholesterol, creatinine and FRAP. Albumin levels were lower in cows with parity $>3$ compared with cows with parity 2 , independent of dry period length. Ceruloplasmin levels were higher in cows with parity $>3$ compared with cows with parity 2, independent of dry period length. In addition, cows with parity $>3$ fed a glucogenic ration had higher cholesterol levels compared with cows fed a lipogenic ration. In the current study, the differences in cholesterol levels among dry period 
lengths were present from week -3 to 1 relative to calving but did not differ after week 1. Previously, it has been suggested that different levels of cholesterol might be affected by ration composition during the dry period (Bertoni and Trevisi, 2013, Newman et al., 2016). In the current experiment, during prepartum, cows with a 0 $\mathrm{d}$ and 30-d dry period had higher DMI and energy intake compared with cows with a 60-d dry period (Van Knegsel et al., 2014). Indeed, during prepartum, cows with a 0 -d dry period received a lactating ration and produced milk, whereas cows with a 30-d and 60-d dry period received a dry cow ration and did not produce milk. It is likely that the differences in cholesterol levels between dry period lengths are explained by the intake and the different rations before calving.

The changes in concentration of APP were affected by internal and external challenges such as infection and stress (Murata et al., 2004, Ceciliani et al., 2012), which can occur in young or old animals. During the first 2 weeks after calving, cows with parity $>3$ cows compared with cows with parity 2 had higher creatinine and FRAP levels in plasma when the dry period was omitted. Creatinine, an indicator of body muscle mass, typically decreases around calving due to milk production (Kokkonen et al., 2005, Osorio et al., 2014). In addition, FRAP is an indicator of antioxidant status (Jacometo et al., 2015, Konvičná et al., 2015), and acts to neutralize the production of reactive intermediates caused by oxidative stress in early lactations (Esposito et al., 2014). Previous studies from Annen et al. (2004) and Santschi et al. (2011) showed a reduction in milk yield after shortening or omitting the dry period for cows with parity 2 , but not for cows with parity $>3$. In our study, during the first 2 weeks after calving, cows with parity $>3$ cows showed less reduction in milk yield when the dry period was omitted compared with cows with parity 2 . Therefore, it seems that the high creatinine and high FRAP levels in plasma of cows with parity $>3$ in the first 2 weeks of lactation compared with cows with parity 2 indicate high mobilization of body muscle mass after calving and less stress perhaps explained by lesser reduction of milk yield when the dry period is omitted.

\subsection{Conclusions}

Omitting the dry period resulted in higher level of cholesterol (negative APP), ceruloplasmin (positive APP), ROM and lower bilirubin, paraoxonase, liver functionality index, and tended to result in higher haptoglobin levels in plasma, compared with cows with a 60-d dry period. Omission of the dry period length is related to a better EB and improvement of metabolic status in the early lactation 
due to less milk yield, which could be also contribute to a reduction of the inflammation and oxidative stress. Low bilirubin is associated with better EB, independent of dry period length. In addition, omission of the dry period is associated with the increase of positive APP and oxidative stress, which could be explained partly by occurrence of clinical health problems.

\subsection{Acknowledgements}

The authors wish to thank the Dutch Dairy Board (PZ, Zoetermeer, the Netherlands), the Product Board Animal Feed (PDV, Zoetermeer, the Netherlands), and CRV (Arnhem, the Netherlands), for financing the experiment. The authors also wish to acknowledge their thanks for the scholarship of Novi Mayasari from the Directorate General of Higher Education, Ministry of National Education, Jakarta, Indonesia. The authors thank Ger de Vries Reilingh, Joop Arts, Mike Nieuwland, Gerrit Remmelink, and the staff of the Dairy Campus (Lelystad, the Netherlands) for their technical support during the experiment and the laboratory analysis. 


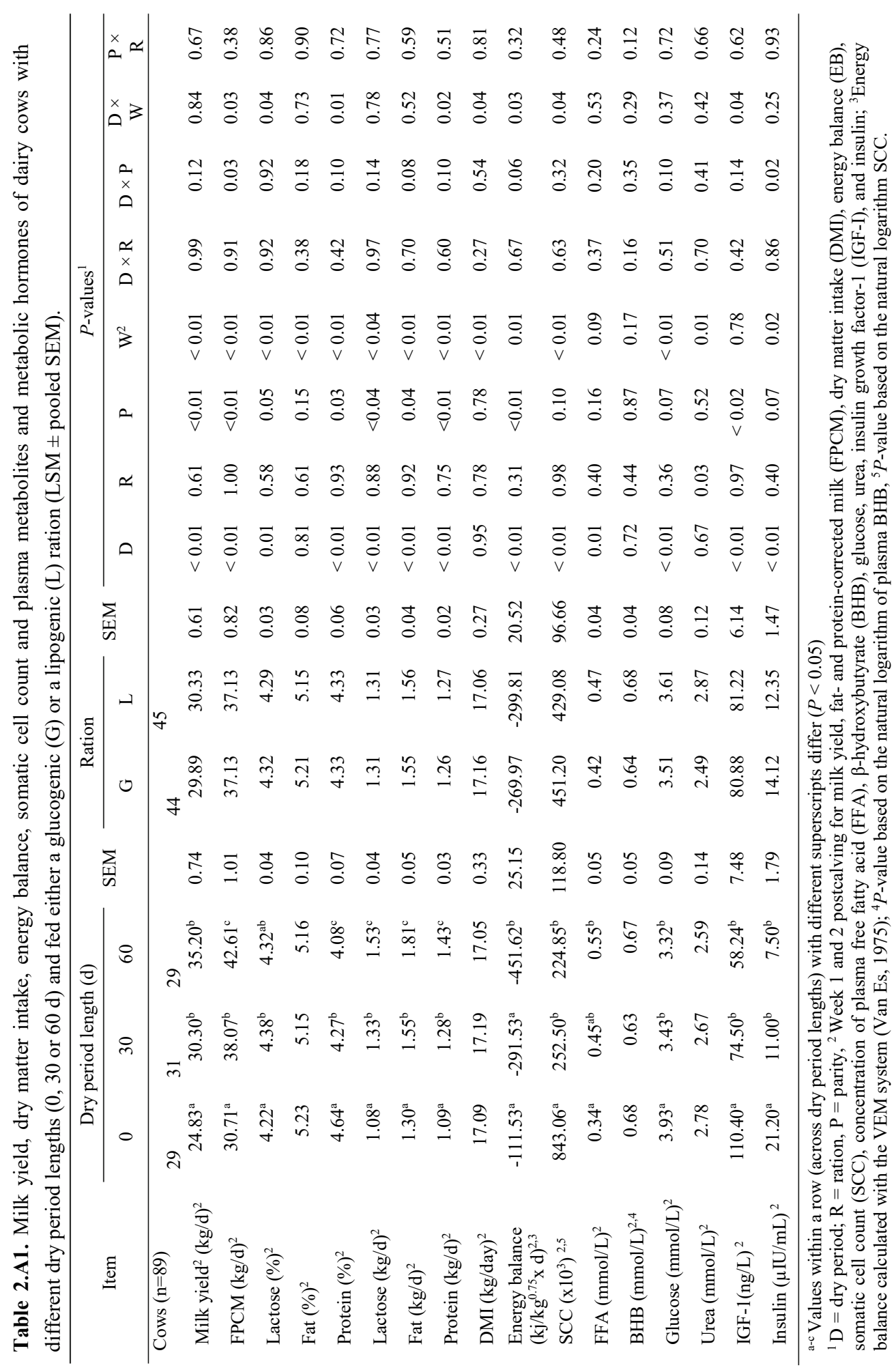




\section{References}

Ametaj, B. N., B. J. Bradford, G. Bobe, R. A. Nafikov, Y. Lu, J. W. Young, and D. C. Beitz. 2005. Strong relationships between mediators of the acute phase response and fatty liver in dairy cows. Can. J. Anim. Sci. 85:165-175.

Annen, E. L., R. J. Collier, M. A. McGuire, J. L. Vicini, J. M. Ballam, and M. J. Lormore. 2004. Effect of modified dry period lengths and bovine somatotropin on yield and composition of milk from dairy cows. J. Dairy Sci. 87:3746-3761.

Assenat, E., S. Gerbal-Chaloin, D. Larrey, J. Saric, J. Fabre, P. Maurel, M. Vilarem, and J. M. Pascussi. 2004. Interleukin $1 \beta$ inhibits CAR-induced expression of hepatic genes involved in drug and bilirubin clearance. Hepato. 40:951-960.

Aviram, M. and M. Rosenblat. 2004. Paraoxonases 1, 2, and 3, oxidative stress, and macrophage foam cell formation during atherosclerosis development. Free Radical Bio. and Med. 37:1304-1316.

Bell, A. W. 1995. Regulation of organic nutrient metabolism during transition from late pregnancy to early lactation. J. Animal Sci. 73:2804-2819.

Benzie, I. F. F. and J. J. Strain. 1996. The ferric reducing ability of plasma (FRAP) as a measure of "antioxidant power": the FRAP assay. Analytical Biochem. 239:70-76.

Bernabucci, U., B. Ronchi, N. Lacetera, and A. Nardone. 2005. Influence of body condition score on relationships between metabolic status and oxidative stress in periparturient dairy cows J. Dairy Sci. 88:2017-2026.

Bertoni, G. and E. Trevisi. 2013. Use of the liver activity index and other metabolic variables in the assessment of metabolic health in dairy herds. Vet. Clinics of North America: Food Animal Prac. 29:413-431.

Bertoni, G., E. Trevisi, X. Han, and M. Bionaz. 2008. Effects of inflammatory conditions on liver activity in puerperium period and consequences for performance in dairy cows. J. Dairy Sci. 91:3300-3310.

Bionaz, M., E. Trevisi, L. Calamari, F. Librandi, A. Ferrari, and G. Bertoni. 2007. Plasma paraoxonase, health, inflammatory conditions, and liver function in transition dairy cows. J. Dairy Sci. 90:1740-1750.

Calamari, L., A. Ferrari, A. Minuti, and E. Trevisi. 2016. Assessment of the main plasma parameters included in a metabolic profile of dairy cow based on Fourier Transform mid-infrared spectroscopy: preliminary results. BMC Vet. Res. 12:1

Ceciliani, F., J. Ceron, P. Eckersall, and H. Sauerwein. 2012. Acute phase proteins in ruminants. J. Proteom. 75:4207-4231.

Chassagne, M., J. Barnouin, and J. P. Chacornac. 1998. Biological predictors for early clinical mastitis occurrence in Holstein cows under field conditions in France. Prev. Vet. Med.35:29-38.

Chen, J., J. J. Gross, H. A. van Dorland, G. J. Remmelink, R. M. Bruckmaier, B. Kemp, and A. T. M. van Knegsel. 2015. Effects of dry period length and dietary energy source on metabolic status and hepatic gene expression of dairy cows in early lactation. J. Dairy Sci. 98:1033-1045.

Church, G. T., L. K. Fox, C. T. Gaskins, D. D. Hancock, and J. M. Gay. 2008. The effect of a shortened dry period on intramammary infections during the subsequent lactation. J. Dairy Sci. 91:4219-4225. 
Conner, J. G., P. D. Eckersall, A. Wiseman, T. C. Aitchison, and T. A. Douglas. 1988. Bovine acute phase response following turpentine injection. Res. Vet. Sci. 44:8288.

CVB (Centraal Veevoederbureau). 2005. Veevoedertabel. Gegevens over chemische samenstelling, verteerbaarheid en voederwaarde van voedermiddelen. CVB, Lelystad, the Netherlands

Drackley, J. K. 1999. Biology of dairy cows during the transition period: The final frontier? J. Dairy Sci. 82:2259-2273.

Enevoldsen, C. and J. T. Sørensen. 1992. Effects of dry period length on clinical mastitis and other major clinical health disorders. J. Dairy Sci. 75:1007-1014.

Esposito, G., P. C. Irons, E. C. Webb, and A. Chapwanya. 2014. Interactions between negative energy balance, metabolic diseases, uterine health and immune response in transition dairy cows. Animal Rep. Sci. 144:60-71.

Ferré, N., J. Camps, E. Prats, E. Vilella, A. Paul, L. Figuera, and J. Joven. 2002. Serum paraoxonase activity: A new additional test for the improved evaluation of chronic liver damage. Clinical Chem. 48:261-268.

Graber, M., S. Kohler, A. Müller, K. Burgermeister, T. Kaufmann, R. M. Bruckmaier, and H. A. van Dorland. 2012. Identification of plasma and hepatic parameters related to metabolic robustness in dairy cows. J. Animal Physiol. Animal Nut. 96:75-84.

Grimble, R. F. 1990. Nutrition and cytokine action. Nutrition Res. Rev. 3:193-210.

Gulay, M. S., M. J. Hayen, K. C. Bachman, T. Belloso, M. Liboni, and H. H. Head. 2003. Milk production and feed intake of holstein cows given short (30-d) or normal (60d) dry periods. J. Dairy Sci 86:2030-2038.

ISO (International Standard Organization) 9622. 2013. Milk and liquid milk products. Guidelines for the application of mid-infrared spectrometry. 2:14

Jacometo, C. B., J. S. Osorio, M. Socha, M. N. Corrêa, F. Piccioli-Cappelli, E. Trevisi, and J. J. Loor. 2015. Maternal consumption of organic trace minerals alters calf systemic and neutrophil mRNA and microRNA indicators of inflammation and oxidative stress. J. Dairy Sci. 98:7717-7729.

James, R. W. and S. P. Deakin. 2004. The importance of high-density lipoproteins for paraoxonase-1 secretion, stability, and activity. Free Radical Bio. Med. 37:19861994.

Kaneene, J. B., R. Miller, T. H. Herdt, and J. C. Gardiner. 1997. The association of serum nonesterified fatty acids and cholesterol, management and feeding practices with peripartum disease in dairy cows. Prev. Vet. Med. 31:59-72.

Kehrli, M. E., J. D. Neill, C. Burvenich, J. P. Goff, J. D. Lippolis, T. A. Reinhardt, and B. J. Nonnecke. 2006. Energy and protein effects on the immune system. Pages 455 471 in Ruminant physiology. Digestion, metabolism and impact of nutrition on gene expression, immunology and stress. Wageningen Academic Publishers, the Netherlands.

Klusmeyer, T. H., A. C. Fitzgerald, A. C. Fabellar, J. M. Ballam, R. A. Cady, and J. L. Vicini. 2009. Effect of recombinant bovine somatotropin and a shortened or no dry period on the performance of lactating dairy cows. J. Dairy Sci. 92:5503-5511.

Kokkonen, T., J. Taponen, T. Anttila, L. Syrjälä-Qvist, C. Delavaud, Y. Chilliard, M. Tuori, and A. T. Tesfa. 2005. Effect of body fatness and glucogenic supplement on lipid and protein mobilization and plasma leptin in dairy cows. J. Dairy Sci. $88: 1127-1141$. 
Konvičná, J., M. Vargová, I. Paulíková, G. Kováč, and Z. Kostecká. 2015. Oxidative stress and antioxidant status in dairy cows during prepartal and postpartal periods. Acta Vet. Brno. 84:133-140.

Köpf, M., K. Gellrich, H. Küchenhoff, H. H. D. Meyer, and H. Kliem. 2014. Effects of continuous milking during a field trial on productivity, milk protein yield and health in dairy cows. Animal 8:1130-1138.

Lacetera, N., D. Scalia, U. Bernabucci, B. Ronchi, D. Pirazzi, and A. Nardone. 2005. Lymphocyte functions in overconditioned cows around parturition. J. Dairy Sci. 88:2010-2016.

LeBlanc, S. J. 2012. Interactions of metabolism, inflammation, and reproductive tract health in the postpartum period in dairy cattle. Reprod. Domest. Anim. 47:18-30.

Littell, R. C., G. A. Milliken, W. W. Stroup, and R. D. Wolfinger. 1996. SAS system for mixed models. SAS Institute, Cary, NC, USA.

Mallard, B. A., J. C. Dekkers, M. J. Ireland, K. E. Leslie, S. Sharif, C. L. Vankampen, L. Wagter, and B. N. Wilkie. 1998. Alteration in immune responsiveness during the peripartum period and its ramification on dairy cow and calf health. J. Dairy Sci. 81:585-595.

Mayasari, N., W. Rijks, G. de Vries Reilingh, G. J. Remmelink, B. Ducro, B. Kemp, H. K. Parmentier, and A. T. M. Van Knegsel. 2016. The effects of dry period length and dietary energy source on natural antibody titers and mammary health in dairy cows. Prev. Vet. Med. 127:1-9.

Minuti, A., Z. Zhou, D. E. Graugnard, S. L. Rodriguez-Zas, A. R. Palladino, F. C. Cardoso, E. Trevisi, and J. J. Loor. 2015. Acute mammary and liver transcriptome responses after an intramammary Escherichia coli lipopolysaccharide challenge in postpartal dairy cows. Phy. Rep. 3. 4.

Murata, H., N. Shimada, and M. Yoshioka. 2004. Current research on acute phase proteins in veterinary diagnosis: an overview. Vet. J. 168:28-40.

Newman, A., S. Mann, D. V. Nydam, T. R. Overton, and E. Behling-Kelly. 2016. Impact of dietary plane of energy during the dry period on lipoprotein parameters in the transition period in dairy cattle. J. Animal Phyiol. Animal Nut. 100:118-126.

Osorio, J. S., E. Trevisi, P. Ji, J. K. Drackley, D. Luchini, G. Bertoni, and J. J. Loor. 2014. Biomarkers of inflammation, metabolism, and oxidative stress in blood, liver, and milk reveal a better immunometabolic status in peripartal cows supplemented with Smartamine M or MetaSmart. J. Dairy Sci. 97:7437-7450.

Owen, J. A., F. C. Better, and J. Hoban. 1960. A simple method for the determination of serum haptoglobins. J. Clin. Pathol. 13:163-164.

Pedernera, M., P. Celi, S. C. García, H. E. Salvin, I. Barchia, and W. J. Fulkerson. 2010. Effect of diet, energy balance and milk production on oxidative stress in earlylactating dairy cows grazing pasture. Vet. J. 186:352-357.

Pezeshki, A., J. Mehrzad, G. R. Ghorbani, H. R. Rahmani, R. J. Collier, and C. Burvenich. 2007. Effects of short dry periods on performance and metabolic status in holstein dairy cows. J. Dairy Sci. 90:5531-5541.

Pyörälä, S. 2003. Indicators of inflammation in the diagnosis of mastitis. Vet. Res. 34:565578.

Rastani, R. R., R. R. Grummer, S. J. Bertics, A. Gümen, M. C. Wiltbank, D. G. Mashek, and M. C. Schwab. 2005. Reducing dry period length to simplify feeding transition cows: milk production, energy balance, and metabolic profiles. J. Dairy Sci. 88:1004-1014. 
Rémond, B., J. Kérouanton, and V. Brocard. 1997. Effets de la réduction de la durée de la période séche ou de son omission sur les performances des vaches laitiéras. INRA Prod. Anim., 10: 301-315

Safi, S., A. Khoshvaghti, S. R. Jafarzadeh, M. Bolourchi, and I. Nowrouzian. 2009. Acute phase proteins in the diagnosis of bovine subclinical mastitis. Vet. Clin. Path. 38:471-476.

Santschi, D. E., D. M. Lefebvre, R. I. Cue, C. L. Girard, and D. Pellerin. 2011. Completelactation milk and component yields following a short (35-d) or a conventional (60-d) dry period management strategy in commercial Holstein herds. J. Dairy Sci. 94:2302-2311.

Sheldon, I. M., D. E. Noakes, A. Rycroft, and H. Dobson. 2001. Acute phase protein responses to uterine bacterial contamination in cattle after calving. Vet. Rec. 148:172-175.

Shoshani, E., S. Rozen, and J. J. Doekes. 2014. Effect of a short dry period on milk yield and content, colostrum quality, fertility, and metabolic status of Holstein cows. J. Dairy Sci. 97:2909-2922.

Skinner, J. G., R. A. Brown, and L. Roberts. 1991. Bovine haptoglobin response in clinically defined field conditions. Vet. Rec. 128:147-149.

Sordillo, L. M., G. Contreras, and S. L. Aitken. 2009. Metabolic factors affecting the inflammatory response of periparturient dairy cows. Anim. Health Res. Rev. 10:53-63.

Sunderman, F. W. and S. Nomoto. 1970. Measurement of human serum ceruloplasmin by its p-phenylenediamine oxidase activity. Clinical Chem. 16:903-910.

Tamminga, S., W. M. Van Straalen, A. P. J. Subnel, R. G. M. Meijer, A. Steg, C. J. G. Wever, and M. C. Blok. 1994. The Dutch protein evaluation system: The DVE/OEB system. Livest. Prod. Sci. 40:139-155.

Trebicka, J., A. Krag, S. Gansweid, B. Appenrodt, P. Schiedermaier, T. Sauerbruch, and U. Spengler. 2011. Endotoxin and tumor necrosis factor-receptor levels in portal and hepatic vein of patients with alcoholic liver cirrhosis receiving elective transjugular intrahepatic portosystemic shunt. European J. Gastroenterol. Hepatol. 23:1218-1225.

Trevisi, E., A. Zecconi, G. Bertoni, and R. Piccinini. 2010. Blood and milk immune and inflammatory profiles in periparturient dairy cows showing a different liver activity index. J. Dairy Res. 77:310-317.

Trevisi, E., A. Zecconi, S. Cogrossi, E. Razzuoli, P. Grossi, and M. Amadori. 2014. Strategies for reduced antibiotic usage in dairy cattle farms. Res. Vet. Sci. 96:229233.

Trevisi, E., L. Moscati, and M. Amadori. 2016. Chapter 9 - Disease-predicting and prognostic potential of innate immune responses to noninfectious stressors: Human and animal models. In "The innate immune response to non-infectious stressors" Edited by M. Amadori. Elsevier Inc. the Netherland. 209-235.

Trevisi, E., M. Amadori, A. M. Bakudila, and G. Bertoni. 2009. Metabolic changes in dairy cows induced by oral, low-dose interferon-alpha treatment. J. Animal Sci. 87:3020-3029.

Trevisi, E., M. Amadori, I. Archetti, N. Lacetera, and G. Bertoni. 2011. Inflammatory response and acute phase proteins in the transition period of high-yielding dairy cows. Pages 355-380 in Acute Phase Proteins. $2^{\text {nd }}$ ed, F. Veas Ed., InTech, Rijeka, Croatia 
Trevisi, E., M. Amadori, S. Cogrossi, E. Razzuoli, and G. Bertoni. 2012a. Metabolic stress and inflammatory response in high-yielding, periparturient dairy cows. Res. Vet. Sci. 93:695-704.

Trevisi, E., P. Grossi, T. Bacchetti, G. Ferretti, and G. Bertoni. 2012b. Variation factors of paraoxonase in blood and in HDL lipoproteins in dairy cow. Prog. Nut. 14:43-49.

Turk, R., C. Piras, M. Kovačić, M. Samardžija, H. Ahmed, M. De Canio, A. Urbani, Z. F. Meštrić, A. Soggiu, L. Bonizzi, and P. Roncada. 2012. Proteomics of inflammatory and oxidative stress response in cows with subclinical and clinical mastitis. J. Proteomics 75:4412-4428.

Turk, R., D. Juretic, D. Geres, N. Turk, B. Rekic, V. Simeon-Rudolf, and A. Svetina. 2004. Serum paraoxonase activity and lipid parameters in the early postpartum period of dairy cows. Res. Vet. Sci. 76:57-61.

Van Es, A. J. H. 1975. Feed evaluation for dairy cows. Livest. Prod. Sci. 4:95-175.

Van Knegsel, A. T. M., G. J. Remmelink, S. Jorjong, V. Fievez, and B. Kemp. 2014. Effect of dry period length and dietary energy source on energy balance, milk yield, and milk composition of dairy cows. J. Dairy Sci. 97:1499-1512.

Vicari, T., J. J. G. C. van den Borne, W. J. J. Gerrits, Y. Zbinden, and J. W. Blum. 2008. Postprandial blood hormone and metabolite concentrations influenced by feeding frequency and feeding level in veal calves. Domest. Anim. Endocrinol. 34:74-88.

Watters, R. D., J. N. Guenther, A. E. Brickner, R. R. Rastani, P. M. Crump, P. W. Clark, and R. R. Grummer. 2008. Effects of dry period length on milk production and health of dairy cattle. J. Dairy Sci. 91:2595-2603. 


\title{
CHAPTER 3
}

\section{Relationships between inflammatory biomarkers and oxidative stress with uterine health in dairy cows with different dry period lengths}

\author{
N. Mayasari" ${ }^{*}$, E. Trevisi , A. Ferrari , B. Kemp*, H. K. Parmentier", \\ A.T.M. van Knegsel ${ }^{*}$ \\ *Adaptation Physiology Group, Department of Animal Science, Wageningen \\ University, P.O. Box 338, $6700 \mathrm{AH}$ Wageningen, the Netherlands; "Faculty of \\ Animal Husbandry, Universitas Padjadjaran, 45636, Bandung, Indonesia; Istituto \\ di Zootecnica, Faculty of Agriculture, Food and Environmental Sciences, \\ Università Cattolica del Sacro Cuore, 29122, Piacenza, Italy
}

To be submitted 


\subsection{Abstract}

The objective of this study was to determine relationships between inflammatory biomarkers and oxidative stress with uterine health in dairy cows with different dry period lengths. Holstein-Friesian dairy cows $(\mathrm{N}=130)$ were assigned randomly to 1 of 3 dry period lengths $(0,30$, or $60 \mathrm{~d})$. Part of the cows which were planned for a 0-d dry period dried themselves off and were attributed to a new group $(0 \rightarrow 30$-d dry period), which resulted in total in 4 dry period groups. Cows were fed a glucogenic or lipogenic ration from $10 \mathrm{~d}$ before the expected calving date. Blood was collected $(\mathrm{N}=110)$ in week $-3,-2,-1,1,2$ and 4 relative to calving to determine inflammatory biomarkers and oxidative stress. Uterine health status (UHS) was monitored by scoring vaginal discharge (VD) based on a 4-point scoring system $(0,1,2$ or 3$)$ in week 2 and 3 after calving. Cows $(\mathrm{N}=91)$ were classified as having a healthy uterine environment $(\mathbf{H U}, \mathrm{VDS}=0$ or 1 in both week 2 and 3), non- recovering uterine environment (NRU, VDS $=2$ or 3 in week 3 ) or a recovering uterine environment $(\mathbf{R U}, \mathrm{VDS}=2$ or 3 in week 2 and VDS $=0$ or 1 in week 3). Cows with NRU had higher haptoglobin and a lower paraoxonase levels in plasma in the first 4 weeks after calving and lower liver functionality index (LFI) compared with cows with HU, independent of dry period length. Cows with NRU had lower albumin and creatinine levels in plasma compared with cows with a RU, but not compared with cows with HU. Independent of UHS, cows a $0 \rightarrow 30$-d dry period had higher bilirubin levels in plasma compared with cows with $0-\mathrm{d}, 30-\mathrm{d}$, or $60-\mathrm{d}$ dry period. Independent of UHS, cows a $60-\mathrm{d}$ dry period had lower creatinine levels in plasma compared with cows with $0 \rightarrow 30$-d or 30 -d dry period, but not compared with cows with a 0 -d dry period. Cows with RU and fed a lipogenic ration had higher levels of albumin in plasma compared with cows with NRU and fed a lipogenic ration. In conclusion, uterine health was related with variables for inflammation (haptoglobin, albumin) and paraoxonase in dairy cows in early lactation. Independent of UHS, cows in the $0 \rightarrow 30-d$ dry period had higher bilirubin and creatinine levels, which was possibly related to a more severe NEB in these cows. Inflammatory biomarkers in dairy in early lactation are related with uterine health in this period.

Key words: continuous milking, uterine health, oxidative stress, inflammation. 


\subsection{Introduction}

Shortening and omitting the dry period is of interest because it has the potential to improve the energy balance (EB) (Rastani et al., 2005, de Feu et al., 2009, Van Knegsel et al., 2014), metabolic status (Rastani et al., 2005, Chen et al., 2015a) and fertility (de Feu et al., 2009, Chen et al., 2015b) of dairy cows in the next lactation. The improvement of the EB is mainly due to a reduction in milk yield in the subsequent lactation (Van Knegsel et al., 2014), and sometimes also to an improvement of the dry matter intake (DMI) in the peripartum period (Rastani et al., 2005). Earlier we reported that cows with a 0-d dry period had increased levels of ceruloplasmin, cholesterol, reactive oxygen metabolites (ROM) and had decreased levels of bilirubin and paraoxonase in plasma, and had decreased liver functionality index (LFI) compared with cows with a 60-d dry period (Mayasari et al., 2017). The effects of dry period length on inflammatory status could partly be explained by the improved EB and occurrence of health problems in cows with a 0 d dry period (Mayasari et al., 2017). In this earlier study, clinical health problems included clinical mastitis, fever, metritis and retained placenta. It can be hypothesized that also other inflammation-related disorders, like metritis or endometritis, could clarify alterations in inflammatory and oxidative stress variables in dairy cows in early lactation.

In early lactation, a severe negative energy balance (NEB) has been related with a greater risk for metritis or endometritis (Hammon et al., 2006, Manimaran et al., 2016). During infection of the uterus, pro-inflammatory cytokines alter the acute phase protein (APP) concentration in plasma (Baumann and Gauldie, 1994) and negatively affect the uterine immunity (Manimaran et al., 2016). Cows with endometritis have an increased culling rate and impaired fertility by reduced pregnancy rate (LeBlanc et al., 2002). Uterus palpation and monitoring of vaginal discharge (VD) has been widely used to diagnose clinical endometritis in dairy cows (LeBlanc et al., 2002, Gilbert et al., 2005, Williams et al., 2005, Prunner et al., 2014). Vaginal discharge has been related to high plasma haptoglobin levels (Huzzey et al., 2009, Dubuc et al., 2010, Ametaj et al., 2014). The relationship between uterine health status (UHS), as indicated by VD, and oxidative stress is unclear. Previous studies showed that metritis and VD were associated with increased oxidative stress (Kizil et al., 2010, Magata et al., 2016), but not all (Bicalho et al., 2014). To our knowledge the relationships between inflammatory biomarkers and oxidative stress with uterine health in dairy cows with different dry period lengths is unknown. The objective of this study was to determine the 
relationships between inflammatory biomarkers and oxidative stress with uterine health in dairy cows in early lactation after different dry period lengths.

\subsection{Materials and Methods}

\subsubsection{Animals and Experimental Design}

The Institutional Animal Care and Use Committee of Wageningen University approved the experimental protocol. The registration number of the experimental protocol was 2010026. The experimental design, dry period lengths and dietary contrast were described earlier (Van Knegsel et al., 2014). Holstein-Friesian dairy cows $(\mathrm{N}=167)$ were selected from the Dairy Campus research herd (WUR Livestock Research, Lelystad, the Netherlands), blocked according to parity, calving date, milk yield in the previous lactation, and body condition score (BCS), and randomly assigned to treatments within blocks. Treatments consisted of 3 dry period lengths $(0,30$, or $60 \mathrm{~d})$ and 2 early lactation rations (glucogenic or lipogenic) resulting in a $3 \times 2$ factorial design. Results of the first lactation after implementation of dry period lengths and dietary treatments have been reported for EB and milk yield (Van Knegsel et al., 2014), metabolites and metabolic hormones (Chen et al., 2015a) and fertility (Chen et al., 2015b). After the first lactation, 37 cows were excluded due to non-pregnancy and health problems. Therefore, the second lactation started with 130 cows: 39 cows with a 0 -d dry period, 41 cows with a 30-d dry period, and 50 cows with a 60-d dry period. Moreover, 19 cows in the 0 - $d$ dry period group were attributed before the second lactation to a new group $(0 \rightarrow 30$-d dry period; actual days dry: $67 \pm 8 \mathrm{~d})$ because these cows had a milk yield of $<4 \mathrm{~kg} / \mathrm{d}$ at least $30 \mathrm{~d}$ before expected calving date and were dried off without use of intramammary antibiotics. Blood was collected from 110 cows. Vaginal discharge was collected and scored in week 2 and 3 after calving from 91 cows according to Williams et al. (2005). Cows were housed in a freestall with slatted floor and cubicles, and milked twice daily (0500 and $1630 \mathrm{~h})$. The dryingoff protocol was as follows: cows with a 30-d or a 60-d dry period received a faroff ration $7 \mathrm{~d}$ before drying-off, were milked once daily $4 \mathrm{~d}$ before drying-off, and were treated with an intramammary antibiotic at drying off (Supermastidol Virbac Animal Health, Barneveld, the Netherlands). Ration composition was described earlier (Van Knegsel et al., 2014). Prepartum, cows with a 30-d and 60-d dry 
period received a dry cow ration, and cows with a 0 - $d$ dry period received a lactating cow ration supporting $25 \mathrm{~kg}$ of milk yield per day. From $10 \mathrm{~d}$ before expected calving onwards, cows of all treatments were fed $1 \mathrm{~kg} / \mathrm{d}$ glucogenic or lipogenic concentrate, which was increased postcalving in steps of $0.5 \mathrm{~kg} / \mathrm{d}$ until the concentration supply reached $8.5 \mathrm{~kg} / \mathrm{d}$. The main ingredient for the glucogenic concentrate was corn, the main ingredients for the lipogenic concentrate were sugar beet pulp, palm kernel, and rumen-protected palm oil. A computerized feeder located in the freestall provided experimental concentrates. In the milking parlor, cows received $1 \mathrm{~kg} / \mathrm{d}$ of standard lactation concentrate. Forage composition did not differ among rations and was supplied ad libitum and consisted prepartum of grass silage, corn silage, wheat straw, and a protein source (rapeseed meal or soybean meal) in a ratio of 39:25:25:11 (DM basis). Postpartum, forage consisted of grass silage, corn silage, wheat straw, and a protein source (rapeseed meal or soybean meal) in a ratio of 51:34:2:13 (DM basis). Rations were isocaloric (net energy basis: Dutch net energy evaluation (VEM) system; Van Es, 1975), and contained equal amounts of intestinal digestible protein and degraded protein (DVE/OEB system; Tamminga et al., 1994). Concentrate and forage were supplied separately.

\subsubsection{Blood Sampling and Analysis}

Blood sampling was described earlier by Chen et al. (2015a). In short, blood samples $(\mathrm{N}=110)$ were taken weekly from the tail vein at $3 \mathrm{~h}$ before the morning feeding from week -3 to 4 relative to calving. Blood was collected in evacuated tubes (Vacuette, Greiner BioOne, Kremsmunster, Austria) containing lithium-heparin for haptoglobin, ceruloplasmin, cholesterol, albumin, bilirubin, paraoxonase, ROM, FRAP, and creatinine. Samples were kept cold on ice for a maximum of $2 \mathrm{~h}$ until they were centrifuged at $3,000 \times \mathrm{g}$ for $15 \mathrm{~min}$ at $4^{\circ} \mathrm{C}$. Plasma was decanted, aliquoted, and frozen at $-20^{\circ} \mathrm{C}$ until analysis.

\subsubsection{Laboratory Analysis}

Determination of inflammatory biomarkers and oxidative stress variables was described earlier by Mayasari et al. (2017). In short, inflammatory biomarkers and oxidative stress were measured at the Istituto di Zootecnica of the Università Cattolica del Sacro Cuore (Piacenza, Italy), following the procedures described previously by Bionaz et al. (2007), Calamari et al. (2016) and Jacometo et al. (2015) 
using a clinical auto-analyzer (ILAB 650, Instrumentation Laboratory, Lexington, MA). In short, total cholesterol (catalog no. 0018250540), albumin (catalog no. 0018250040), total bilirubin (catalog no. 0018254640), and creatinine (catalog no. 0018255540) were measured using the IL Test purchased from Instrumentation Laboratory Spa (Werfen Co., Milan, Italy). The haptoglobin was determined with the method described by Skinner et al. (1991) and Owen et al. (1960), adapted to ILAB 650 condition. The method based on peroxidase activity of methaemoglobinhaptoglobin complex measured by the rate of oxidation of guaiacol (hydrogen donor) in the presence of hydrogen peroxide (oxidizing substrate). The ceruloplasmin was determined with the method described by Sunderman and Nomoto (1970), adapted to ILAB 650 conditions. The test is based on measurement of the colour which originates from the oxidation of the $p$-phenylenediamine dihydrochloride induced by the ceruloplasmin. The ROM was measured using commercial kits (kit d-ROMs-test cod. MC003; Diacron International s.r.l., Grosseto, Italy) adapted to the ILAB 650 conditions. Antioxidant potential was assessed as ferric reducing antioxidant power (FRAP) using the colorimetric method of Benzie and Strain (1996). Plasma paraoxonase activity was measured by adapting the method of Ferré et al. (2002) to the ILAB 650 conditions.

\subsubsection{Vaginal Discharge Scoring}

Vaginal discharge collection and scoring has been described earlier (Chen et al., submitted). Vaginal discharge was scored based on a 4-point scoring system according to Williams et al. (2005): score $0=$ clear translucent mucus, score $1=$ clear translucent mucus with discrete flecks of purulent exudate present, score $2=$ discharge containing $<50$ percent white or off-white mucopurulent material, and score 3 = discharge containing $>50$ percent purulent material.

\subsubsection{Statistical Analyses}

The MIXED procedure of SAS (SAS version 9.2; SAS Institute Inc., Cary, $\mathrm{NC}$, (Littell et al., 1996) for repeated measures analysis was used to analyze the effects of dry period lengths and rations on inflammatory biomarkers and oxidative stress (model 1). Fixed effects in model 1 were dry period length $(0,30,60$, or $0 \rightarrow$ $30 \mathrm{~d}$ ), ration (glucogenic or lipogenic), parity (3,4 or $>4$ ), week relative to calving $(-3,-2,-1,1,2$ and 4$)$, and their 2-way interactions. Preliminary result showed that 
the levels of bilirubin for all samples was relatively low compared earlier studies (Bionaz et al., 2007, Bertoni et al., 2008, Trevisi et al., 2012a). The animal experiment was performed from 2010 until 2013, and the prolonged storage condition of the plasma samples may have affected the level of bilirubin. However, in the current study the dynamic of bilirubin levels by week around calving followed the typical pattern of change observed in the peripartum period in earlier studies (Ametaj et al., 2005, Bionaz et al., 2007, Trevisi et al., 2012a). All the plasma parameters have been setted with calibration curves, and data were standardized using quality control standards (internal and purchased by Instrumentation Laboratory, Lexington, MA). Liver functionality index was calculated according to Trevisi et al. (2012). Albumin, cholesterol, and bilirubin data were used to calculate the LFI. Statistical analysis for LFI was performed in the first 4 weeks after calving with model 1 .

The MIXED procedure of SAS was used to analyze the relation of uterine health status (UHS) with inflammatory biomarkers and oxidative stress. Cows were classified as having a healthy uterine environment (HU, VDS $=0$ or 1 in both week 2 and 3), non-recovering uterine environment (NRU, VDS $=2$ or 3 in week 3) or a recovering uterine environment $(\mathbf{R U}, \mathrm{VDS}=2$ or 3 in week 2 and $\mathrm{VDS}=0$ or 1 in week 3). To analyze the relation between inflammatory biomarkers and oxidative stress with UHS, the MIXED procedure of SAS was used (model 2). Fixed effects in model 2 were uterine health status (HU, NRU or RU), dry period lengths, ration, parity, week, and their 2-way interactions in separate analyses one by one. In model 1 and 2, cow was considered as the repeated subject. Preliminary analysis showed that number of cows per category of UHS $\times$ dry period length was small (range 1 to 15 ), thus this interaction was not included in model 2. The [AR (1)] covariate structure was the best fit, and was used to account for within-cow variation. For comparison of dry period length effects $P$-values are presented after a Tukey-Kramer adjustment. Values are presented as least squares means (LSM) with their pooled standard errors of the mean (SEM), unless otherwise stated. 


\subsection{Results}

\subsubsection{Effects of Dry Period Length and Ration on Inflammatory Biomarkers, Liver Functionality and Oxidative Stress in Plasma of Cows}

Cows with a 0-d dry period had higher levels of ceruloplasmin in plasma compared with cows with a $0 \rightarrow 30-\mathrm{d}, 30$-d or 60 -d dry period from 3 weeks before calving until 4 weeks after calving (Table 3.1). Cows with a 0-d dry period had higher levels of ROM in plasma compared with cows with a 30-d or 60-d dry period from 3 weeks before calving until 4 weeks after calving, but not compared with cows with a $0 \rightarrow 30$-d dry period. Plasma bilirubin levels did not differ among cows with a 0 -d, 30-d or 60-d dry period. Cows with a $0 \rightarrow 30$-d dry period had greater bilirubin levels in plasma compared with cows with a $0-d, 30-d$ or $60-d$ dry period especially in the first 2 weeks after calving. Cows with a 0 -d dry period had a higher LFI compared with cows with a 30-d, $0 \rightarrow 30-\mathrm{d}$ and $60-\mathrm{d}$ dry period in the first 4 weeks after calving. Cows with a $0 \rightarrow 30$-d dry period had higher creatinine levels in plasma compared with cows with a 60-d dry period, but not compared with cows a 0-d and 30-d dry period. Dry period length had no effect on levels of haptoglobin or cholesterol in plasma. Rations had no effect on levels of bilirubin or paraoxonase in plasma. Cows fed a lipogenic ration had higher cholesterol levels in plasma and higher LFI compared with cows fed a glucogenic ration. There was an interaction between dry period $\times$ ration for FRAP and creatinine. Cows with a 0 -d dry period fed a lipogenic ration had higher FRAP and creatinine levels in plasma compared with cows with a $0-d$ dry period and fed a glucogenic ration. There was an interaction between dry period $\times$ parity for albumin. Cows with $0 \rightarrow 30 \mathrm{~d}$ dry period had higher albumin levels in plasma in cows with parity 4 compared with cows with parity 3 . Contrary, cows with a 0 -d, a $30-d$ or a 60 -d dry period had lower albumin levels in plasma in cows with parity $\geq 4$ compared with cows with parity 3 .

\subsubsection{Relationships of Uterine Health Status with Inflammatory Biomarkers and Oxidative Stress}

Cows with NRU had higher haptoglobin levels in plasma compared with cows with $\mathrm{HU}$, but not compared with cows with RU, independent of dry period length (Table 3.2). Cows with NRU had lower paraoxonase levels in plasma and 
LFI compared with cows with $\mathrm{HU}$ or RU, independent of dry period length. In addition, cows with NRU had lower albumin and creatinine levels in plasma compared with cows with a RU, but not compared with cows with HU. There was an interaction between UHS $\times$ ration and dry period length $\times$ parity for plasma albumin levels (Figure 3.1). Cows with RU and fed a lipogenic ration had higher levels of albumin in plasma compared with cows with NRU and fed a lipogenic ration. Cows with a 30-d dry period had higher levels of albumin in plasma in cows with parity 3 compared with cows with parity $>4$. There was an interaction between UHS $\times$ week for haptoglobin (Figure 3.2). In addition, cows with NRU had higher levels of haptoglobin, lower albumin, paraoxonase and creatinine in plasma compared with cows with UH or RU especially in the first 4 weeks after calving.

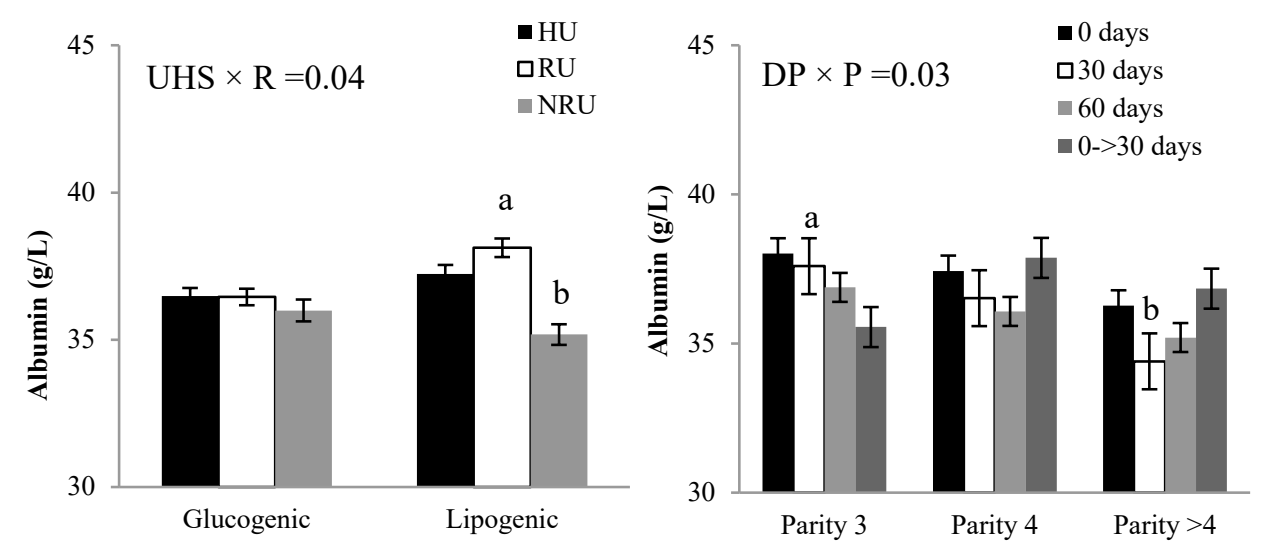

Figure 3.1 Interaction between ration (glucogenic vs. lipogenic) and uterine health status (UHS; a healthy uterine environment (HU), a recovering uterine environment (RU) and a non-recovering uterine environment (NRU)) and interaction between dry period length $(0,30,0 \rightarrow 30$ or 60 d dry period) $\times$ parity $(3,4$ or $>4)$ for albumin $($ Mean \pm SEM). Bar with different superscripts within dry period length (DP), ration (R), or parity (P) class differ $(P<$ $0.05)$. 

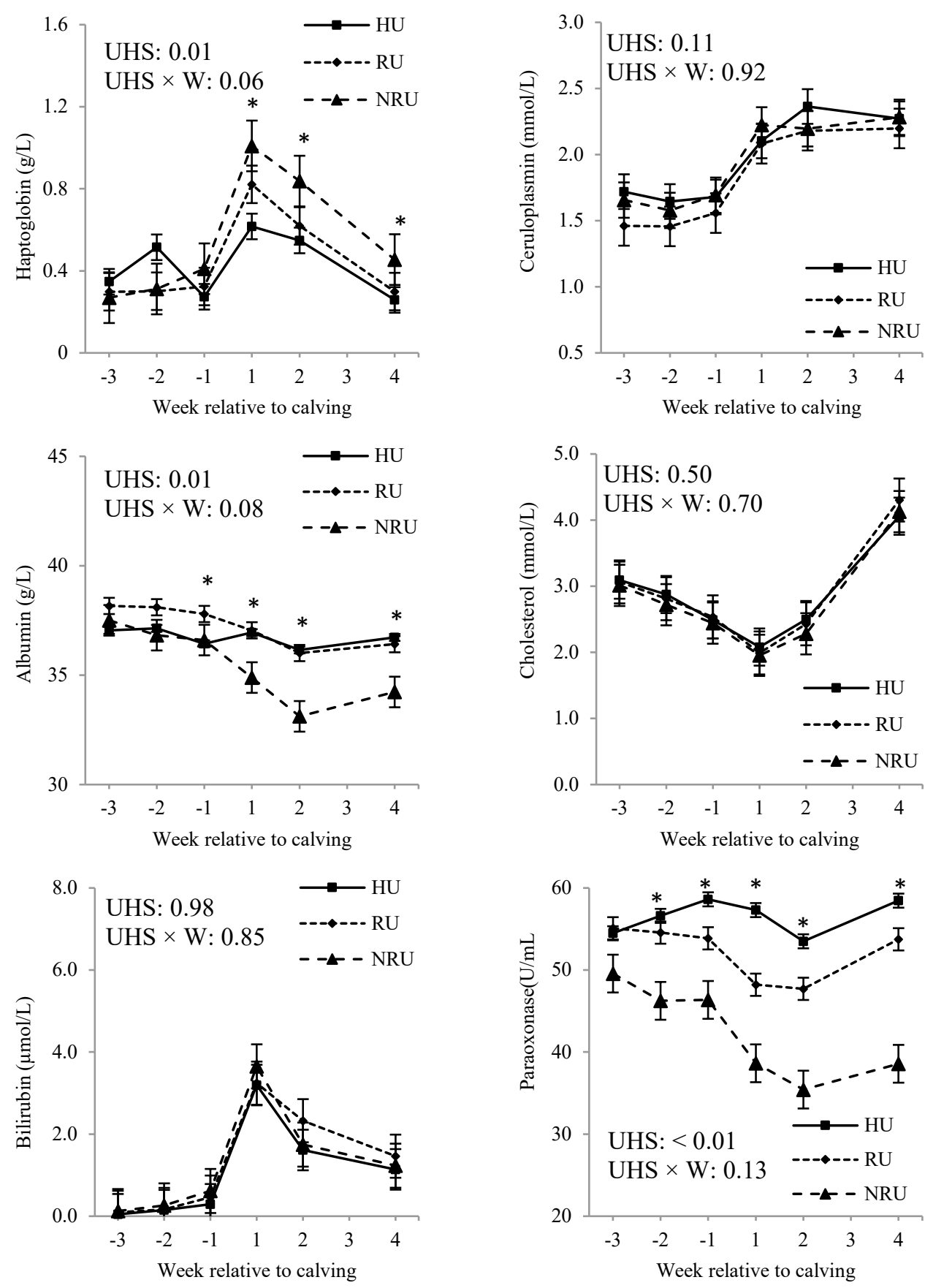

Continued to the next page 

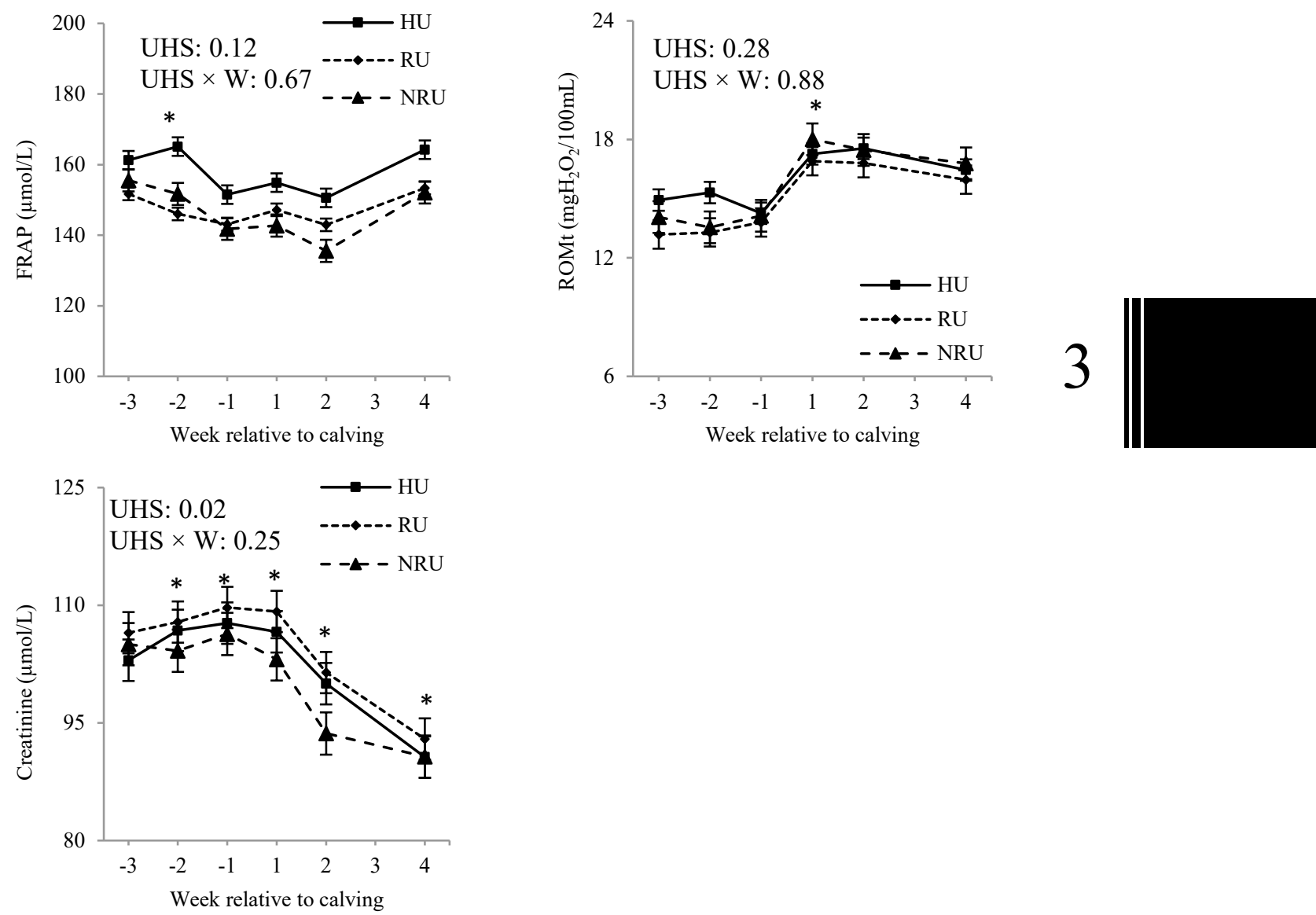

Figure 3.2 Inflammatory biomarkers, oxidative stress (reactive oxidative metabolites (ROM) and ferric reducing antioxidant power (FRAP)) and creatinine in plasma per week per 3 group of uterine health status (UHS); a healthy uterine environment (HU; vaginal discharge score (VDS: 0 or 1 in week 2 and score 0 or 1 in week $3(\mathrm{~N}=17)$, a recovering uterine environment (RU; VDS: 2 or 3 in week 2 and score 0 or 1 in week 3 $(\mathrm{N}=31)$, and a non-recovering uterine environment (NRU; VDS: 2 or 3 in week $3(\mathrm{~N}=43))(\mathrm{Mean} \pm \mathrm{SEM})$. Significant UHS group differences within a week are indicated by $*(P<0.05)$. 


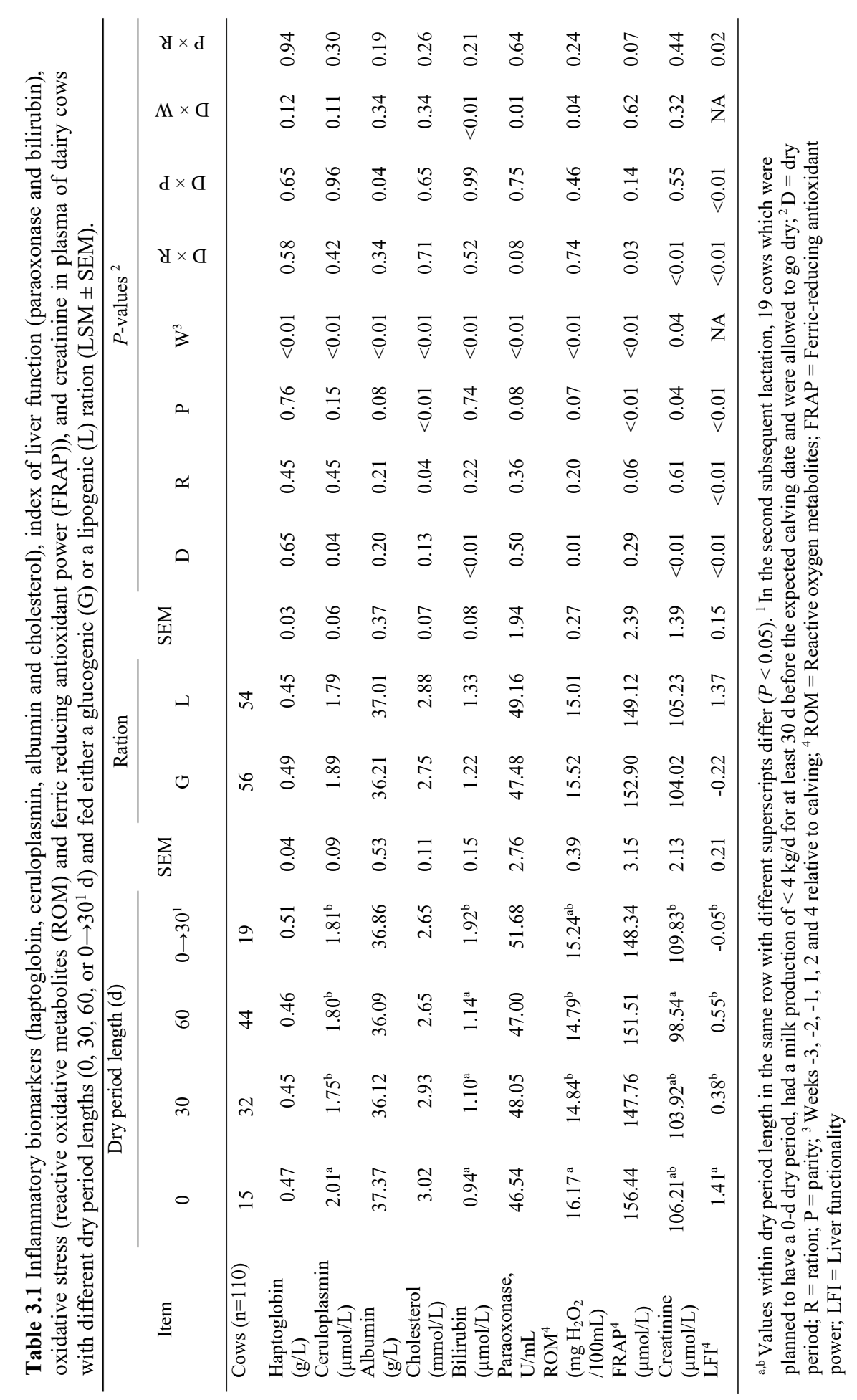




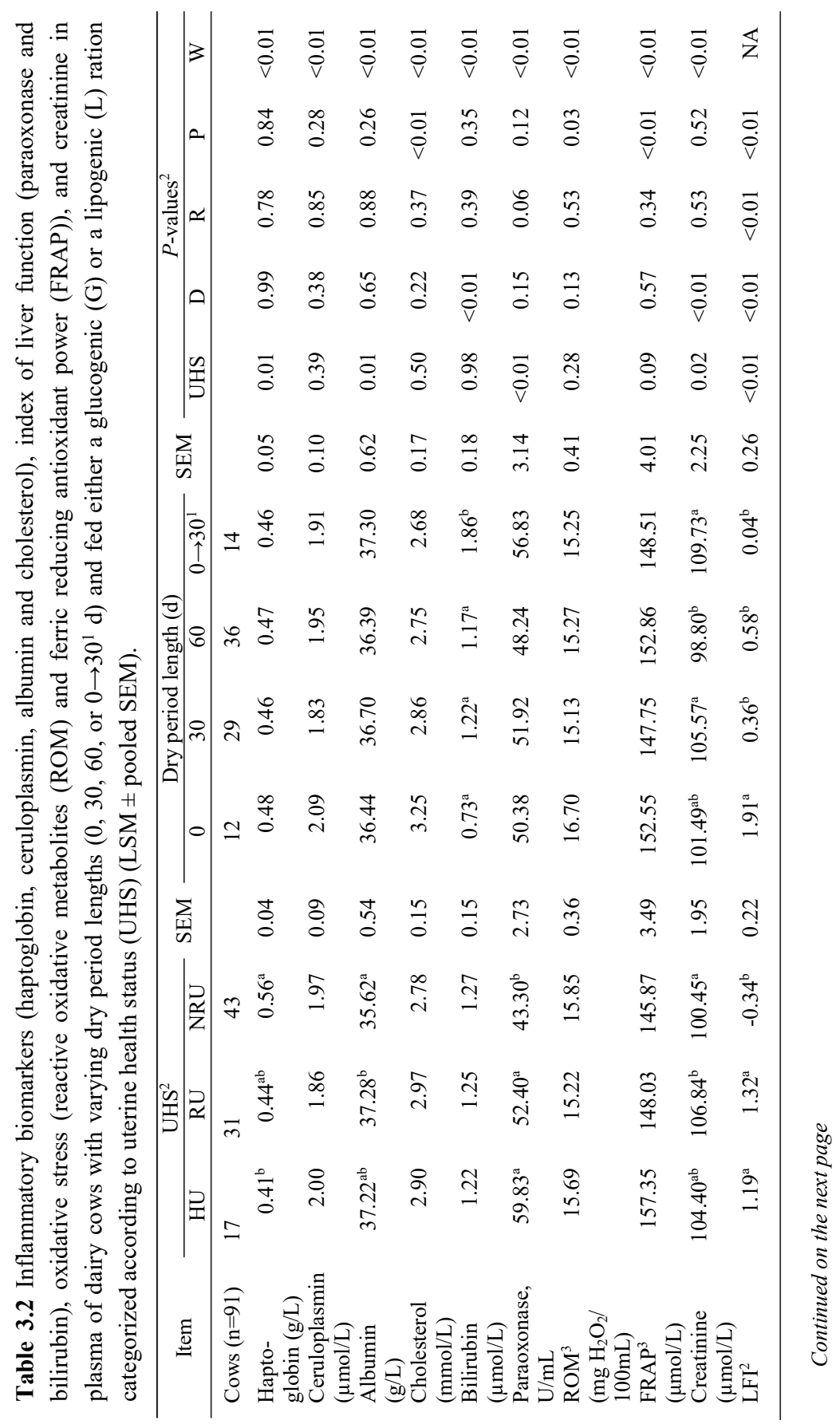

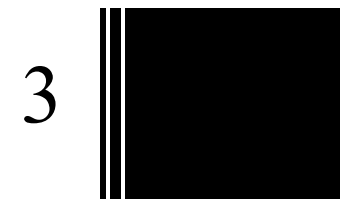


Table 3.2 continued

\begin{tabular}{|c|c|c|c|c|}
\hline \multirow{2}{*}{ Item } & \multicolumn{4}{|c|}{$P$-values ${ }^{2}$} \\
\hline & $\mathrm{D} \times \mathrm{P}$ & $\mathrm{D} \times \mathrm{W}$ & $\mathrm{P} \times \mathrm{R}$ & $\mathrm{UHS} \times \mathrm{R}$ \\
\hline \multicolumn{5}{|l|}{ Cows $(n=91)$} \\
\hline Haptoglobin $(\mathrm{g} / \mathrm{L})$ & 0.66 & 0.35 & 0.93 & 0.93 \\
\hline Ceruloplasmin $(\mu \mathrm{mol} / \mathrm{L})$ & 0.31 & 0.03 & 0.43 & 0.43 \\
\hline Albumin $(\mathrm{g} / \mathrm{L})$ & 0.62 & 0.48 & 0.02 & 0.02 \\
\hline Cholesterol $(\mathrm{mmol} / \mathrm{L})$ & 0.83 & 0.73 & 0.89 & 0.89 \\
\hline Bilirubin $(\mu \mathrm{mol} / \mathrm{L})$ & 0.71 & $<0.01$ & 0.08 & 0.08 \\
\hline Paraoxonase, $\mathrm{U} / \mathrm{mL}$ & 0.26 & 0.49 & 0.73 & 0.73 \\
\hline $\mathrm{ROM}^{3}\left(\mathrm{mg} \mathrm{H}_{2} \mathrm{O}_{2} / 100 \mathrm{~mL}\right)$ & 0.69 & 0.08 & 0.57 & 0.57 \\
\hline $\operatorname{FRAP}^{3}(\mu \mathrm{mol} / \mathrm{L})$ & 0.16 & 0.58 & 0.41 & 0.41 \\
\hline Creatinine $(\mu \mathrm{mol} / \mathrm{L})$ & 0.60 & 0.31 & 0.02 & 0.02 \\
\hline $\mathrm{LFI}^{2}$ & $<0.01$ & NA & $<0.01$ & $<0.01$ \\
\hline
\end{tabular}

${ }^{\mathrm{a}, \mathrm{b}}$ Values within dry period length in the same row with different superscripts $\operatorname{differ}(P<0.05) ;{ }^{1}$ In the second subsequent lactation, 19 cows which were planned to have a 0 -d dry period, had a milk production of $<4 \mathrm{~kg} / \mathrm{d}$ for at least $30 \mathrm{~d}$ before the expected calving date and were allowed to go dry; ${ }^{2} \mathrm{D}=$ dry period; $\mathrm{R}=$ ration; $\mathrm{P}$ = parity; LFI; liver functionality index; UHS=uterine health status; $\mathrm{HU}=$ healthy uterine environment: vaginal discharge score $(\mathrm{VDS})=0$ or 1 in both week 2 and 3; $\mathrm{RU}=$ a recovering uterine environment: $\mathrm{VDS}=2$ or 3 in week 2 and score $=0$ or 1 in week 3 ; NRU= non-recovering uterine environment: VDS: 2 or 3 in week $3 ;{ }^{3} \mathrm{ROM}=$ Reactive oxygen metabolites; FRAP $=$ Ferric-reducing antioxidant power; ${ }^{4} \mathrm{D} \times \mathrm{R}$, UHS $\times \mathrm{W}$ and $\mathrm{UHS} \times \mathrm{P}$ are included in the model, but not significant. UHS $\times \mathrm{D}$ are excluded from the model because of fewer animals in the group. 


\subsection{Discussion}

In the current study, independent of dry period length or ration, cows with NRU had higher haptoglobin levels in plasma compared with cows with HU, but not compared with cows with RU. Cows with NRU had lower paraoxonase levels in plasma and LFI compared with cows with HU or RU, independent of dry period length. In addition, cows with NRU had lower albumin levels in plasma compared with cows with a RU, but not compared with cows with HU. Our finding is in line with a previous study where cows with an uterine infection had lower albumin, lower paraoxonase and higher haptoglobin levels in plasma compared with cows with healthy uterus (Schneider et al., 2013). Cows with retained placenta and endometriosis had lower levels of plasma albumin as negative APP (Fleck, 1989) compared with healthy cows (Green et al., 2009, Burke et al., 2010). Paraoxonase is mainly synthesized in the liver, considered as negative APP and a marker for liver functionality (Feingold et al., 1998). Low plasma paraoxonase level was associated with increased occurrence of metritis in early lactation (Bionaz et al., 2007). Previous studies showed that cows with uterine infection had high haptoglobin levels in plasma (Chan et al., 2010, Hassanpour et al., 2011, Pohl et al., 2015). Plasma haptoglobin increased in cows with retained fetal membranes (Mordak, 2009). Retained fetal membranes is a key risk factor for uterine infection (Mordak, 2009). Total bilirubin, albumin and vitamin A have been proposed as possible indicators for retained fetal membranes (Trevisi et al., 2008). In the current study, we found no evidence that haptoglobin is an indicator or a consequence of uterine infection. Recently, the level of haptoglobin in plasma has been considered as biomarker to predict uterine infection in early lactation (Williams et al., 2005, Huzzey et al., 2009). In the current study, levels of haptoglobin in plasma were associated with uterine health.

In the present study the increase of ceruloplasmin and ROM was affected by both dry period length and uterine health status. In this study, levels of ceruloplasmin were positively associated with level of ROM in plasma $(r=0.83, P$ $<0.01$ ), independent of dry period length. In addition, levels of ROM were negatively associated with level of paraoxonase in plasma $(r=-0.19, P<0.01)$. Cows with acute puerperal metritis had higher oxidative stress, indicated by high malondialdehyde concentrations compared with healthy cows (Kizil et al., 2010, Magata et al., 2016). Increased plasma malondialdehyde concentration which is a thiobarbituric acid reactive species, indicate oxidative status (Bernabucci et al., 2005). Cows with endometritis had higher ceruloplasmin levels in plasma as 
positive APP compared with healthy cows (Kaya et al., 2016). During inflammation, copper binding ceruloplasmin mediated formation of reactive oxygen species and may promote oxidative pathology (Shukla et al., 2006). This study suggests that ROM is positively related with ceruloplasmin.

In the current study, cows with a 0-d dry period had higher ceruloplasmin and higher ROM levels in plasma compared with cows with a 60-d dry period, independent of UHS. In our earlier study, high levels of ceruloplasmin and ROM in plasma of cows with a 0 -d dry period could partly be explained by the occurrence of clinical health problems related to inflammation such as clinical mastitis, metritis, retained placenta and fever (Mayasari et al., 2017). Earlier in this experiment, dry period length did not affect UHS (Chen et al., submitted). Albeit, VD is related with inflammation in the uterus (Ametaj et al., 2005, Bionaz et al., 2007, Trevisi et al., 2012) and might result in changes of inflammatory biomarkers and oxidative stress variables, VD was not affected by dry period length treatment in the current study. This result indicated that high levels of ceruloplasmin and ROM in plasma of cows with 0-d dry period could not be explained by UHS but may be caused by other specific diseases related with inflammation in these cows.

Plasma bilirubin levels did not differ among dry period lengths (0-d vs. 30-d or $60-\mathrm{d}$ dry period). Cows with $0 \rightarrow 30-\mathrm{d}$ dry period had higher plasma bilirubin levels compared with cows with $0-\mathrm{d}, 30-\mathrm{d}$ or $60-\mathrm{d}$ dry period, independent of UHS. Cows with a $0 \rightarrow 30-\mathrm{d}$ dry period had a more severe NEB compared with cows with a 0-d or 30-d dry period (Chen et al., 2016). Moreover, cows with 0-d dry period had a less pronounced improvement of EB and metabolic status in early lactation in the current study, compared with the first lactation after implementation of a short or no dry period strategy (Chen et al., 2016). In the first subsequent lactation, a better EB was related with low plasma bilirubin levels (Mayasari et al., 2017). The limited differences in EB among dry period groups in the second lactation may explain the lack of effect of dry period length on bilirubin in the second lactation, compared with the first lactation after implementation of dry period length treatments.

In the present study, cows with NRU had lower creatinine levels compared with cows with RU, but not compared with HU. In contrast with earlier studies that cows with endometritis had higher creatinine in plasma compared with cows with a healthy uterus (Sattler and Fürll, 2004, Kaya et al., 2016). In our study, cows with a $0 \rightarrow 30-\mathrm{d}$ dry period had higher creatinine levels in plasma compared with cows with a 60-d dry period, independent of UHS. A previous study showed that cows 
with high $\mathrm{BCS}$ group $(\mathrm{BCS} \geq 3.75)$ had higher plasma creatinine and severe NEB compared with cows with low BCS group (BCS $\leq 2.5$ ) (Pires et al., 2013). For this experiment, cows with a $0 \rightarrow 30-\mathrm{d}$ dry period had higher BCS (4.3 \pm 0.3$)$ compared with cows with a 30 -d $(3.4 \pm 0.2)$ or 60 -d $(3.2 \pm 0.1)$ dry period during 3 weeks before calving. In addition, cows with a $0 \rightarrow 30-\mathrm{d}$ dry period had a more severe NEB compared with cows with a $0-d$ or $30-d$ dry period (Chen et al., 2016). This result indicated that high plasma creatinine levels in cows with a $0 \rightarrow 30-d$ dry period was related to high precalving BCS and a more severe NEB in these cows, but could not be explained by uterine health status in these cows.

In the current study, cows fed a lipogenic ration had increased cholesterol levels in plasma compared with cows fed a glucogenic ration, independent of UHS or dry period length. In addition, cows with RU and fed a lipogenic ration had higher levels of albumin in plasma compared with cows with NRU and fed a lipogenic ration. A previous study showed that cows with a dietary fat supplementation of 5 percent in ration showed increased plasma cholesterol levels in plasma compared with cows not receiving fat supplementation (Carroll et al., 1990). Cholesterol is known as negative APP (i.e. apolipoproteins) and also a precursor for steroid hormone synthesis and it may increase in plasma by feeding supplemental fat to dairy cows (Grummer and Carroll, 1991). Albumin is not only associated with fat infiltration in the liver, but also as risk for uterine diseases (Bobe et al., 2004), and an important protein to transport long-chain fatty acids from adipocyte triacylglycerol stores to muscle tissue (Spector, 1986). Therefore, it is likely that high albumin levels in plasma in cows with RU and fed a lipogenic ration may be due to intense transport of fat in these cows, compared with cows with NRU. In any case, the higher concentration of albumin in plasma during the peripartum reflects a less inflammation of the cows.

As we suggested earlier, the increased positive APP (ceruloplasmin) and ROM in plasma in early lactation could partly be explained by many factors such as dry period length, ration and occurrence of clinical health problem related inflammation. In the current study, increased haptoglobin and reduced paraoxonase and albumin were related with uterine infection, independent of dry period length. This suggests that the inflammatory status attributed to NEB should be disentangled in various concurrently operating inflammatory responses. This implies that uterine health status that considered as one of clinical health problem related with inflammation may explain the changes in inflammatory biomarkers. 


\subsection{Conclusions}

Cows with a NRU had higher levels of haptogloblin and lower paraoxonase in plasma compared with cows with a $\mathrm{HU}$, independent of dry period length. Cows with a RU had higher levels of albumin and creatinine in plasma in the first 4 weeks after calving and a higher liver functionality index compared with cows with a NRU. Cows fed lipogenic had higher levels of albumin in plasma in the cows with RU compared with cows with NRU. This study shows that uterine health is associated with variables of inflammation (haptoglobin and albumin) and paraoxonase, independent of dry period length. Cows with $0 \rightarrow 30-d$ dry period had high plasma bilirubin, which is related with severe NEB in the early lactation in comparison to other groups. In addition, omission of the dry period is associated with the high positive APP and oxidative stress that could partly be explained by poor uterine health status indicated by vaginal discharge the first 3 weeks after calving.

\subsection{Acknowledgements}

The authors wish to thank the Dutch Dairy Board (PZ, Zoetermeer, the Netherlands), the Product Board Animal Feed (PDV, Zoetermeer, the Netherlands), and CRV (Arnhem, the Netherlands), for financing the experiment. The authors also wish to thanks the Directorate General of Higher Education, Ministry of National Education, Jakarta, Indonesia for the scholarship of Novi Mayasari. The authors thank the staff of the Dairy Campus (Lelystad, the Netherlands) for their technical support during the experiment. 


\section{References}

Ametaj, B. N., S. Iqbal, F. Selami, J. F. Odhiambo, Y. Wang, M. G. Gänzle, S. M. Dunn, and Q. Zebeli. 2014. Intravaginal administration of lactic acid bacteria modulated the incidence of purulent vaginal discharges, plasma haptoglobin concentrations, and milk production in dairy cows. Res. Vet. Sci. 96:365-370.

Baumann, H. and J. Gauldie. 1994. The acute phase response. Immunol. Today 15:74-80.

Benzie, I. F. F. and J. J. Strain. 1996. The ferric reducing ability of plasma (FRAP) as a measure of "antioxidant power": the FRAP assay. Analytical Biochem. 239:70-76.

Bernabucci, U., B. Ronchi, N. Lacetera, and A. Nardone. 2005. Influence of body condition score on relationships between metabolic status and oxidative stress in periparturient dairy cows. J. Dairy Sci. 88:2017-2026.

Bertoni, G., E. Trevisi, X. Han, and M. Bionaz. 2008. Effects of inflammatory conditions on liver activity in puerperium period and consequences for performance in dairy cows. J. Dairy Sci. 91:3300-3310.

Bicalho, M. L. S., F. S. Lima, E. K. Ganda, C. Foditsch, E. B. S. Meira Jr, V. S. Machado, A. G. V. Teixeira, G. Oikonomou, R. O. Gilbert, and R. C. Bicalho. 2014. Effect of trace mineral supplementation on selected minerals, energy metabolites, oxidative stress, and immune parameters and its association with uterine diseases in dairy cattle. J. Dairy Sci. 97:4281-4295.

Bionaz, M., E. Trevisi, L. Calamari, F. Librandi, A. Ferrari, and G. Bertoni. 2007. Plasma paraoxonase, health, inflammatory conditions, and liver function in transition dairy cows. J. Dairy Sci. 90:1740-1750.

Bobe, G., J. W. Young, and D. C. Beitz. 2004. Invited review: Pathology, etiology, prevention, and treatment of fatty liver in dairy cows. J. Dairy Sci. 87:3105-3124.

Burke, C. R., S. Meier, S. McDougall, C. Compton, M. Mitchell, and J. R. Roche. 2010. Relationships between endometritis and metabolic state during the transition period in pasture-grazed dairy cows. J. Dairy Sci. 93:5363-5373.

Calamari, L., A. Ferrari, A. Minuti, and E. Trevisi. 2016. Assessment of the main plasma parameters included in a metabolic profile of dairy cow based on Fourier Transform mid-infrared spectroscopy: preliminary results. BMC Vet. Res. 12:1.

Carroll, D. J., M. J. Jerred, R. R. Grummer, D. K. Combs, R. A. Pierson, and E. R. Hauser. 1990. Effects of fat supplementation and immature alfalfa to concentrate ratio on plasma progesterone, energy balance, and reproductive traits of dairy cattle. J. Dairy Sci. 73:2855-2863.

Chan, J. P., C. Chang, W. Hsu, W. Liu, and T. Chen. 2010. Association of increased serum acute - phase protein concentrations with reproductive performance in dairy cows with postpartum metritis. Vet. Clinical Pathol. 39:72-78.

Chen, J., J. J. Gross, H. A. van Dorland, G. J. Remmelink, R. M. Bruckmaier, B. Kemp, and A. T. M. van Knegsel. 2015a. Effects of dry period length and dietary energy source on metabolic status and hepatic gene expression of dairy cows in early lactation. J.Dairy Sci. 98:1033-1045.

Chen, J., G. J. Remmelink, J. J. Gross, R. M. Bruckmaier, B. Kemp, and A. T. M. van Knegsel. 2016. Effects of dry period length and dietary energy source on milk yield, energy balance, and metabolic status of dairy cows over 2 consecutive years: Effects in the second year. J. Dairy Sci. 99: 4826-4838 
Chen, J., N. M. Soede, H. A. van Dorland, G. J. Remmelink, R. M. Bruckmaier, B. Kemp, and A. T. M. van Knegsel. 2015b. Relationship between metabolism and ovarian activity in dairy cows with different dry period lengths. Theriogenol. 8:1387-1396.

Dubuc, J., T. F. Duffield, K. E. Leslie, J. S. Walton, and S. J. LeBlanc. 2010. Risk factors for postpartum uterine diseases in dairy cows. J. Dairy Sci. 93:5764-5771.

Feingold, K. R., R. A. Memon, A. H. Moser, and C. Grunfeld. 1998. Paraoxonase activity in the serum and hepatic mRNA levels decrease during the acute phase response. Atherosclerosis 139:307-315.

Fleck, A. 1989. Clinical and nutritional aspects of changes in acute-phase proteins during inflammation. Proc. Nut. Society 48:347-354.

Ferré, N., J. Camps, E. Prats, E. Vilella, A. Paul, L. Figuera, and J. Joven. 2002. Serum paraoxonase activity: A new additional test for the improved evaluation of chronic liver damage. Clinical Chem. 48:261-268.

Gilbert, R. O., S. T. Shin, C. L. Guard, H. N. Erb, and M. Frajblat. 2005. Prevalence of endometritis and its effects on reproductive performance of dairy cows. Theriogenology 64:1879-1888.

Green, M. P., A. M. Ledgard, M. C. Berg, A. J. Peterson, and P. J. Back. 2009. Prevalence and identification of systemic markers of sub-clinical endometritis in postpartum dairy cows. Pages 37-42 in Proc of the New Zealand Society of Animal Production. New Zealand Society of Animal Production.

Grummer, R. R. and D. J. Carroll. 1991. Effects of dietary fat on metabolic disorders and reproductive performance of dairy cattle. J. Animal Sci. 69:3838-3852.

Gümen, A., R. Rastani, R. Grummer, and M. Wiltbank. 2005. Reduced dry periods and varying prepartum diets alter postpartum ovulation and reproductive measures. J. Dairy Sci. 88:2401-2411.

Hammon, D. S., I. M. Evjen, T. R. Dhiman, J. P. Goff, and J. L. Walters. 2006. Neutrophil function and energy status in Holstein cows with uterine health disorders. Vet. Immunol. and Immunopathol. 113:21-29.

Hassanpour, A., M. Gholipour, and A. Rezaie. 2011. The effect of using monensin on haptoglobin serum level in dairy cattle. J. Animal Vet. Advanc.10:1364-1367.

Huzzey, J. M., T. F. Duffield, S. J. LeBlanc, D. M. Veira, D. M. Weary, and M. A. G. Von Keyserlingk. 2009. Short communication: Haptoglobin as an early indicator of metritis. J. Dairy Sci. 92:621-625.

Jacometo, C. B., J. S. Osorio, M. Socha, M. N. Corrêa, F. Piccioli-Cappelli, E. Trevisi, and J. J. Loor. 2015. Maternal consumption of organic trace minerals alters calf systemic and neutrophil mRNA and microRNA indicators of inflammation and oxidative stress. J. Dairy Sci. 98:7717-7729.

Kaya, S., O. Merhan, C. Kacar, A. Colak, and K. Bozukluhan. 2016. Determination of ceruloplasmin, some other acute phase proteins, and biochemical parameters in cows with endometritis. Vet. World 9:1056-1062.

Kizil, O., Y. Akar, M. Yuksel, and N. Saat. 2010. Oxidative stress in cows with acute puerperal metritis. Revue Méd. Vét. 161:353-357.

LeBlanc, S., T. Duffield, K. Leslie, K. Bateman, G. P. Keefe, J. Walton, and W. Johnson. 2002. Defining and diagnosing postpartum clinical endometritis and its impact on reproductive performance in dairy cows. J. Dairy Sci. 85:2223-2236.

Littell, R. C., G. A. Milliken, W. W. Stroup, and R. D. Wolfinger. 1996. SAS system for mixed models. SAS Institute, Cary, NC, USA. 
Magata, F., I. Morino, M. Teramura, E. Tsunoda, C. Kawashima, S. Haneda, A. Miyamoto, K. Kida, and T. Shimizu. 2016. Impact of metritis on the generation of reactive oxygen species by circulating phagocytes and plasma lipopolysaccharide concentration in peripartum dairy cows. Animal Sci. J. Online.

Manimaran, A., A. Kumaresan, S. Jeyakumar, T. K. Mohanty, V. Sejian, N. Kumar, L. Sreela, M. A. Prakash, P. Mooventhan, A. Anantharaj, and D. N. Das. 2016. Potential of acute phase proteins as predictor of postpartum uterine infections during transition period and its regulatory mechanism in dairy cattle. Vet.World 9:91-100.

Mayasari, N., J. Chen, A. Ferrari, R. M. Bruckmaier, B. Kemp, H. K. Parmentier, A. T. M. van Knegsel, and E. Trevisi. 2017. Effects of dry period length and dietary energy source on inflammatory biomarkers and oxidative stress in dairy cows. J. Dairy Scci. In press.

Mordak, R. 2009. Postpartum serum concentration of Haptoglobin in cows with fetal membranes retention. Cattle Pract. 17:100-102.

Owen, J. A., F. C. Better, and J. Hoban. 1960. A simple method for the determination of serum haptoglobins. J. Clin. Pathol. 13:163-164.

Pires, J. A. A., C. Delavaud, Y. Faulconnier, D. Pomies, and Y. Chilliard. 2013. Effects of body condition score at calving on indicators of fat and protein mobilization of periparturient Holstein-Friesian cows. J. Dairy Sci. 96:6423-6439.

Pohl, A., O. Burfeind, and W. Heuwieser. 2015. The associations between postpartum serum haptoglobin concentration and metabolic status, calving difficulties, retained fetal membranes, and metritis. J. Dairy Sci. 98:4544-4551.

Prunner, I., H. Pothmann, K. Wagener, M. Giuliodori, J. Huber, M. Ehling-Schulz, and M. Drillich. 2014. Dynamics of bacteriologic and cytologic changes in the uterus of postpartum dairy cows. Theriogenology 82:1316-1322.

Sattler, T. and M. Fürll. 2004. Creatine kinase and aspartate aminotransferase in cows as indicators for endometritis. Transboundary and Emerging Diseases. 51:132-137.

Schneider, A., M. N. Corrêa, and W. R. Butler. 2013. Short communication: Acute phase proteins in Holstein cows diagnosed with uterine infection. Res. Vet. Sci. 95:269271.

Skinner, J. G., R. A. Brown, and L. Roberts. 1991. Bovine haptoglobin response in clinically defined field conditions. Vet. Rec. 128:147-149.

Spector, A. A. 1986. Structure and lipid binding properties of serum albumin. Meth. Enzymol. 128:320-339.

Sunderman, F. W. and S. Nomoto. 1970. Measurement of human serum ceruloplasmin by its p-phenylenediamine oxidase activity. Clinical Chem. 16:903-910.

Tamminga, S., W. M. Van Straalen, A. P. J. Subnel, R. G. M. Meijer, A. Steg, C. J. G. Wever, and M. C. Blok. 1994. The Dutch protein evaluation system: The DVE/OEB system. Livest. Prod. Sci. 40:139-155.

Trevisi, E., M. Amadori, S. Cogrossi, E. Razzuoli, and G. Bertoni. 2012. Metabolic stress and inflammatory response in high-yielding, periparturient dairy cows. Res. Vet. Sci. 93:695-704.

Trevisi, E., A. R. Ferrari, and G. Bertoni. 2008. Productive and metabolic consequences induced by the retained placenta in dairy cows. Vet. Res. Com. 32:363-366.

Van Es, A. J. H. 1975. Feed evaluation for dairy cows. Livest. Prod. Sci. 4:95-175. 
Van Knegsel, A. T. M., G. J. Remmelink, S. Jorjong, V. Fievez, and B. Kemp. 2014. Effect of dry period length and dietary energy source on energy balance, milk yield, and milk composition of dairy cows. J. Dairy Sci. 97:1499-1512.

Williams, E., D. Fischer, D. Pfeiffer, G. England, D. Noakes, H. Dobson, and I. Sheldon. 2005. Clinical evaluation of postpartum vaginal mucus reflects uterine bacterial infection and the immune response in cattle. Theriogenology 63:102-117. 


\section{CHAPTER 4}

The effects of dry period length and dietary energy source on natural antibody titers and mammary health in dairy cows

N. Mayasari*†, W. Rijks*, G. de Vries Reilingh*, G. J. Remmelink", B. Ducro ${ }^{\S}$ B. Kemp*, H. K. Parmentier*, and A. T. M. Van Knegsel*

*Adaptation Physiology Group, Department of Animal Science, Wageningen University, P.O. Box 338, 6700 AH Wageningen, the Netherlands; "Faculty of Animal Husbandry, Universitas Padjadjaran, 45363, Bandung, Indonesia; Livestock Research, Wageningen University and Research Centre, P.O. Box 338, 6700 AH Wageningen, the Netherlands; ${ }^{\S}$ Animal Breeding and Genomics Centre, Wageningen University, P.O. Box 338, 6700 AH Wageningen, the Netherlands

Preventive Veterinary Medicine (2016) 127: 1-9

DOI: 10.1016/j.prevetmed.2016.03.001 


\subsection{Abstract}

In earlier studies, natural antibodies (NAb) were related not only to the energy balance (EB) of dairy cows, but also to somatic cell count (SCC) and clinical mastitis. The first objective of our study was to evaluate the effects of dry period length and dietary energy source on titers of NAb binding keyhole limpet hemocyanin (KLH) and lipopolysaccharide (LPS) in plasma and milk, SCC and clinical mastitis occurrence in dairy cows in 2 subsequent lactations. Our second objective was to study the relationship between NAb levels and mammary health. Holstein-Friesian dairy cows $(\mathrm{N}=167)$ were randomly assigned to 3 dry period lengths $(0,30$ or $60 \mathrm{~d})$ and 2 early lactation rations (glucogenic or lipogenic). Treatments were repeated during 2 subsequent lactations. In the second lactation after implementation of dry period length treatments, 19 cows which were planned to have 0 -d dry period dried off naturally and were assigned to an additional group $0 \rightarrow 30$-d dry period. In the first lactation after implementation of dry period length treatments, cows with a 0-d dry period had a higher SCC, a higher titer of immunoglobulin $\mathrm{G}(\mathrm{IgG})$ binding LPS in plasma, and higher titers of $\mathrm{IgG}$ and $\operatorname{IgM}$ binding KLH and LPS in milk compared with cows with a 30-d or 60-d dry period. In the second lactation after implementation of dry period length treatments, cows with a 60-d dry period had a lower SCC than cows with a 30-d and $0 \rightarrow 30-d$ dry periods. In the second lactation after implementation of dry period length treatments, dry period length did not affect NAb titers in plasma or milk. The clinical mastitis occurrence was 17 percent in the first lactation and 25 percent in the second lactation, and did not differ according to dry period lengths or rations. For both lactations, an increasing titer of $\operatorname{IgG}$ binding LPS in plasma was associated with decreased odds of a high SCC and decreased odds of clinical mastitis occurrence. Also up to 3 weeks before the clinical mastitis occurrence, an increasing titer of IgM binding KLH and LPS in plasma was associated with a decreased odds of clinical mastitis occurrence. In conclusion, omitting the dry period increased SCC, NAb titers in milk and IgG binding LPS in plasma compared with a short (30-d) or conventional (60-d) dry period. The effects on $\mathrm{NAb}$ titers, however, were only present in the first lactation after omitting the dry period and disappeared after repeated omitting the dry period. Moreover, an increasing titer of IgG binding LPS in plasma was associated with decreased odds of high SCC and clinical mastitis occurrence.

Key words: continuous milking, nutrition, somatic cell count, clinical mastitis. 


\subsection{Introduction}

Natural antibodies (NAb) are a humoral part of innate immunity (Matter and Ochsenbein, 2008, Vollmers and Brändlein, 2009) and are present in healthy individuals without apparent antigenic stimulation (Ochsenbein and Zinkernagel, 2000). Natural antibodies are polyreactive and have a low affinity binding with various antigens (Casali and Notkins, 1989). In human and mice, NAb are produced by $\mathrm{CD}^{+} \mathrm{B}-1$ cells, and mainly consist of immunoglobulin $\mathrm{M}(\mathbf{I g M})$, and to a lesser extent immunoglobulin G (IgG) and immunoglobulin A (IgA) (Kohler et al., 2003, Avrameas, 2006). Natural antibodies act as a first line of defense against infection through neutralization, complement system activation and pathogen elimination (Ochsenbein et al., 1999, Zinkernagel, 2012). For dairy cows, NAb titers are present in both plasma and milk (Van Knegsel et al., 2007, Ploegaert, 2010). In previous research, we reported higher titers of NAb binding keyhole limpet hemocyanin (KLH) in plasma for cows with an improved energy balance (EB) in early lactation (Van Knegsel et al., 2007). In this earlier work, the EB was improved by feeding a more glucogenic ration, compared with a lipogenic ration. In other studies, also shortening or omitting the dry period has been shown to improve EB of dairy cows in the subsequent lactation (Rastani et al. 2005, Van Knegsel et al. 2014). Hence, it can be hypothesized that shortening or omitting the dry period improves the EB in dairy cows in early lactation, also $\mathrm{NAb}$ titers in plasma increase.

Earlier studies showed variable effects of dry period length on mammary health (Annen et al., 2004, Watters et al., 2008, Köpf et al., 2014). A shortened dry period (34-40 d) did not result in differences in somatic cell count (SCC) (Watters et al., 2008, Bernier-Dodier et al., 2011, Shoshani et al., 2014) or clinical mastitis (Enevoldsen and Sørensen, 1992, Watters et al., 2008, Shoshani et al., 2014), compared with a conventional dry period (55 to 65 d). From some studies (Annen et al., 2004, Klusmeyer et al., 2009) it was concluded that omitting the dry period resulted in higher SCC values compared with cows with a 56-d dry period, but in other studies (Rastani et al., 2005, Köpf et al., 2014) no effect of omitting the dry period on SCC was present. No dry period lowered the odds of new infections during the dry period, but it has been hypothesized that no dry period also imposes the odds of an increased SCC because cows cannot be treated with long-acting intramammary antibiotics (Annen et al., 2004). When the dry period is reduced from $56 \mathrm{~d}$ to $0 \mathrm{~d}$, Rastani et al. (2005) reported an increase in clinical mastitis occurrence (9.5 percent vs. 14.3 percent), whereas 
Schlamberger et al. (2010) reported a decrease in clinical mastitis occurrence (41.7 percent vs. 25.0 percent). Both studies, however, had a limited number of animal (44 and 36 cows, respectively), which justifies evaluation of effects of dry period omission on clinical mastitis occurrence in a larger study.

It has been suggested that NAb play a role in the prevention of clinical mastitis or lead to a high SCC depending on the NAb isotype and antigenspecificity (Ploegaert, 2010). Thompson-Crispi et al. (2013) showed that an increasing titer of IgM binding KLH in plasma was associated with decreased odds of clinical mastitis occurrence (unadjusted odds ratio of 0.96), while no relationship was found with levels of IgG binding KLH. In the study of ThompsonCrispi et al. (2013), NAb titers were related to the clinical mastitis occurrence at anytime during the study period. We hypothesized that if NAb play a role in the development or prevention of clinical mastitis occurrence, alterations in NAb titers are already detectable days or weeks prior to the clinical mastitis occurrence. This hypothesis was tested for NAb in milk against auto-antigens (Van Knegsel et al., 2012). In this study, a higher NAb binding transferrin tended to have an association with decreased odds of clinical mastitis occurrence in the week of clinical mastitis diagnosis but not earlier.

The first objective of this study was to evaluate the effects of dry period length and dietary energy source on titers of NAb-binding KLH and LPS in plasma and milk, SCC in milk, and clinical mastitis occurrence in dairy cows in 2 subsequent lactations. The second objective was to study the relationship between $\mathrm{NAb}$ and mammary health as characterized by a high SCC and clinical mastitis occurrence.

\subsection{Materials and Methods}

\subsubsection{Experimental Design and Animals}

The Institutional Animal Care and Use Committee of Wageningen University approved the experimental protocol. The registration number of the experimental protocol is 2010026 . The experimental design, dry period lengths and dietary contrast were described by Van Knegsel et al. (2014). In summary, 167 Holstein-Friesian dairy cows were selected from the Dairy Campus research herd (WUR Livestock Research, Lelystad, the Netherlands), blocked according to parity, calving date, milk yield in previous lactation, and body condition score (BCS), and randomly assigned to treatments within blocks. In total, 28 blocks were 
used and each block consisted of 6 cows, 1 cow for each treatment ( 28 blocks $\times 6$ animals $=168$ cows, 1 cow was excluded because she received the wrong diet at drying off). Only cows were selected which had SCC $<250,000$ cells $/ \mathrm{mL}$ at the last and second last monthly test day recordings. Treatments consisted of 3 dry period lengths $(0,30$ or $60 \mathrm{~d})$ and 2 early lactation rations (glucogenic or lipogenic) resulting in a $3 \times 2$ factorial design. The same treatments were imposed on cows for 2 subsequent lactations. Cows used in this study were clinically healthy. Cows were housed in a free stall with slatted floor and cubicles, and milked twice daily (at 0500 and $1630 \mathrm{~h}$ ). The drying-off protocol for both lactations was as follows: cows with a $30-\mathrm{d}$ or a $60-\mathrm{d}$ dry period received a far-off ration $7 \mathrm{~d}$ before drying-off, were milked once daily $4 \mathrm{~d}$ before drying-off, and all were treated with an intramammary antibiotic treatment at drying off (Supermastidol, Virbac Animal Health, Barneveld, the Netherlands). This treatment aims to prevent clinical mastitis occurrence during or after the dry period. In the first lactation after implementation of dry period length treatments, all cows which were planned to have a 0 -d dry period were milked till calving. In the second lactation after implementation of dry period length treatments, 19 cows of the 0 -d dry period group had a milk yield of less than $4 \mathrm{~kg} / \mathrm{d}$ for at least $30 \mathrm{~d}$ before the expected calving date and were assigned to the $0 \rightarrow 30-\mathrm{d}$ dry period group. These cows were allowed to go dry without use of antibiotics, and received a dry cow ration during the dry period.

The first lactation started with 167 Holstein-Friesian dairy cows (60 primiparous and 107 multiparous cows). The second lactation started with 130 cows, 37 cows had been removed from the study because 18 cows did not become pregnant ( 8 cows with a 0 -d dry period, 8 cows with a $30-d$ dry period and 2 cows with a 60-d dry period), 8 cows had leg problems ( 3 cows with a 0 -d dry period, 3 cows with a 30-d dry period and 2 cows with 60-d dry period), 3 cows with 0 -d dry period had udder problems, 8 cows had been removed for other reasons such as abortion and pneumonia ( 3 cows with 0 -d dry period, 3 cows with 30-d dry period, 2 cows with 60 -d dry period).

\subsubsection{Rations}

Ration composition was described earlier (Van Knegsel et al., 2014). Prepartum, dry cows received a dry cow ration, and lactating cows received a lactating cow ration supporting $25 \mathrm{~kg}$ of milk yield per day. From $10 \mathrm{~d}$ before expected calving onwards, cows of all treatments were fed $1 \mathrm{~kg} / \mathrm{d}$ glucogenic or 
lipogenic concentrate, which was increased postcalving in steps of $0.5 \mathrm{~kg} / \mathrm{d}$ until the concentration supply reached $8.5 \mathrm{~kg} / \mathrm{d}$. The main ingredient for the glucogenic concentrate was corn, the main ingredients for the lipogenic concentrate were sugar beet pulp, palm kernel, and rumen protected palm oil. Forage composition did not differ among dry cow rations, was supplied ad libitum, and consisted of grass silage, corn silage, wheat straw, and a protein source (rapeseed meal or soybean meal) in the ratio of 39:25:25:11 (DM basis). Postpartum, forage consisted of grass silage, corn silage, straw, and a protein source (rapeseed meal or soybean meal) in the ratio 51:34:2:13 (DM basis). Rations were isocaloric (net energy basis: Dutch net energy evaluation (VEM) system, Van Es, 1975), and contained equal amounts of intestinal digestible protein and degraded protein balance (DVE/OEB system, Tamminga et al., 1994).

\subsubsection{Milk and Plasma Sample Collection}

Blood samples were taken weekly from week -3 till 9 relative to calving from 92 cows in the first lactation after implementation of dry period length treatments, and 114 cows in the second lactation after implementation of dry period length treatments. The number of blood samples in the first lactation is lower than in the second lactation, animal numbers were lower because 37 cows were removed from the study. Moreover, at start of second lactations some cows from 0 $\mathrm{d}$ dry period dried themselves off, which resulted in an extra treatment group $(0 \rightarrow 30$ group). As soon as it was clear this extra treatment group was present, it was decided to take blood samples from all cows in the second lactation. This was short after the start of second lactation, resulting in a blood sample collection of 114 cows for the second lactation. In both lactations, blood samples were taken from the tail vein in Vacutainer tubes $(10 \mathrm{~mL}$, Greiner Bio-One $\mathrm{GmbH}$, Kremsmunster, Austria) containing heparin as an anticoagulant. Blood samples were centrifuged at $3000 \times \mathrm{g}$ at $4^{\circ} \mathrm{C}$, for $15 \mathrm{~min}$, and within $2 \mathrm{~h}$ of collection. Plasma was harvested and stored at $-20^{\circ} \mathrm{C}$ until analysis. Milk samples were collected from 163 cows in the first lactation and 120 cows in the second lactation. Milk samples for NAb measurement were collected weekly on Fridays. Composite milk samples for SCC determination (Qlip NV, Zutphen, the Netherlands) were collected from individual cows 4 times a week (on Tuesday afternoon, Wednesday morning, Wednesday afternoon, and Thursday morning). Milk samples $(10 \mathrm{~mL}$, VWR International Ltd., Leighton Buzzard, UK) were stored at $-20^{\circ} \mathrm{C}$ until analysis. High SCC values in milk was defined as being at least 250,000 cells $/ \mathrm{mL}$, 
and low SCC in milk as less than 250,000 cells/mL. Clinical mastitis was defined as cows with abnormalities in milk (flakes, clots or watery appearance), abnormalities associated with the udder (heat, swelling, or sensitivity to touch) and treated with intramammary antibiotic. The clinical mastitis occurrence was recorded at cow level per week.

\subsubsection{Laboratory Analysis}

Milk and plasma samples were thawed to room temperature before analysis. Titers of NAb binding Megathura crenulata-derived KLH (Sigma, H7017 Sigma Aldrich Co., St Louis, MO) and Escherichia coli 055:B5 LPS (Sigma) in plasma and milk of the cows were measured by an indirect enzymelinked immunosorbent assay (ELISA) technique, as described by Van Knegsel et al. (2007). Natural antibodies in plasma and milk of IgG isotype were detected using respectively, 1:20,000 and 1:40,000, diluted sheep anti-bovine IgG-heavy chain conjugated to horseradish peroxidase (Cat. No. E10-118P, Bethyl Laboratories). Natural antibodies of the IgM isotype in plasma and milk samples were detected using diluted rabbit anti-bovine IgM-whole molecule conjugated to horseradish peroxidase (Cat. No. A10-100P, Bethyl Laboratories) in the ratio 1:20,000. Four-step serial dilutions for both $\operatorname{IgG}$ and $\operatorname{IgM}$ in plasma and milk samples started with the ratio 1:40. After washing, a substrate containing tetra methyl benzidine (Sigma) and 0.05 percent $\mathrm{H}_{2} \mathrm{O}_{2}$ was added, and incubated for $10 \mathrm{~min}$ at room temperature. The reaction was stopped by adding $1.25 \mathrm{M}$ sulfuric acid. Extinctions were measured with a Multiskan reader (Lab Systems, Helsinki, Finland) at a wavelength of $450 \mathrm{~nm}$. Titers were defined as $\log 2$ values of the dilutions that gave an extinction closest to 50 percent of Emax, where Emax represents the highest mean extinction of a standard positive (pooled) serum present on each microtiter plate (Ploegaert et al., 2007).

The increase of 1 titer of NAb implies that 1 observation increases $2^{1}$ compared with the observations the titer is compared with. In other words, " 1 titer" difference is doubling the levels of antibodies.

\subsubsection{Statistical Analysis}

As several successive measurements were taken per cow, observations within cows cannot be considered independent. Therefore, repeated measurement analyses were performed.

The NAb titers of IgG and IgM binding KLH or LPS in plasma or milk, 
and SCC in milk, were analyzed using PROC MIXED in SAS 9.2 (SAS Inst. Inc. Cary, NC). A repeated measurement analysis with cows as the subject was used applying a first order auto-regressive [AR (1)] variance-covariance structure determined to be the best fit according to Akaike's corrected information criterion (Aikake, 1997). Data from the first and second lactation after implementation of dry period length treatments were analyzed separately. The fixed class effect of dry period length $(0,30$, or $60 \mathrm{~d}$ for the first lactation; $0,30,60$, or $0 \rightarrow 30 \mathrm{~d}$ for the second lactation), ration (glucogenic or lipogenic), parity $(2(\mathrm{~N}=60), 3(\mathrm{~N}=53)$ or $>3(\mathrm{~N}=54)$ for the first lactation and $3(\mathrm{~N}=53), 4(\mathrm{~N}=41)$ or $>4(\mathrm{~N}=36)$ for the second lactation), week ( -3 to 9 weeks relative to calving for NAb titers in plasma, and 1 - 14 weeks relative to calving for NAb titers in milk), and their 2way interactions were assessed. Cow was considered as the repeated subject (Model 1). To approximate normality, the natural logarithm of SCC values used in the analysis. All other variables approximated normality of residuals by examining whether skewness and kurtosis were in a range of -2 until 2. Multiple comparisons adjustments were performed using the Bonferroni adjustment method. Values are presented as least squares means (LSM) with their pooled standard errors of the mean (SEM), unless otherwise stated.

High SCC and clinical mastitis occurrence were analyzed in PROC GENMOD in SAS 9.2 with a binary distribution and a logit link. A repeated measurement analysis (GEE model) was used with cows as the subject applying an $\mathrm{AR}(1)$ variance-covariance structure determined to be the best fit according to Akaike's corrected information criterion. The same fixed effects as described for model 1 were assessed (Model 2).

To assess the association of NAb titers in milk or in plasma with the odds of a high SCC or the clinical mastitis occurrence, each individual NAb titers was assessed in separate models as a continuous fixed effect added to the fixed effects described in model 2 with all possible 2- way interactions (Model 3). Linearity to the logit of the continuous fixed effects was confirmed using the Box-Tidwell method. Preliminary analysis showed that the relationships between NAb titers and high SCC or clinical mastitis occurrence were similar for both lactations. Therefore, data in both lactations were analyzed simultaneously. The relationships between NAb titers and the odds of a high SCC or clinical mastitis occurrence, were analyzed with; NAb titers as continous variable, dry period length $(0,30,60$, or $0 \rightarrow 30 \mathrm{~d}$ ), ration (glucogenic or lipogenic), parity ( $\leq 3$ or $>3$ ), week ( -3 to 9 weeks relative to calving for NAb titers in plasma; $1-14$ weeks relative to calving 
for NAb titers in milk), with their interactions included as fixed effects (Model 3). The AR (1) was the best fit, and was used to account for within-cow variation. A backward elimination procedure was performed using a stay-in $P$ value of $<0.05$ except for dry period length that was forced in all models. Confounding was monitored as described by Santman-Berends et al. (2012). To study the relationships between NAb titers in milk or plasma with high SCC or clinical mastitis occurrence during the week of high SCC or clinical mastitis occurrence and in the 3 weeks before high SCC or clinical mastitis occurrence, a separate model (Model 4) for each week was built. Analyses showed there were no relationships between NAb titers in milk with high SCC or clinical mastitis occurrence during the week of high SCC or clinical mastitis occurrence, nor in the 3 weeks before. Therefore, these results are not shown. Results of the effect of NAb titers in plasma for high SCC or clinical mastitis occurrence are presented as the relative risk (odds ratio).

\subsection{Results}

In the first lactation after implementation of dry period length treatments, the average number of days dry were $61 \pm 1,30 \pm 1$, and $2 \pm 1 \mathrm{~d}$ dry (means \pm SEM) for cows with a $60-d$, a $30-d$ or a 0 -d dry period, respectively. In the second lactation after implementation of dry period length treatments, the actual number of days dry were: $64 \pm 2,40 \pm 5,0 \pm 0 \mathrm{~d}$ dry (means \pm SEM) for cows with a $60-\mathrm{d}$, a 30 -d or a 0 -d dry period, respectively. Cows in the $0 \rightarrow 30$-d group had an average dry period of $67 \pm 8 \mathrm{~d}$.

\subsubsection{Effects of Dry Period Length and Ration on Natural Antibodies in Plasma (Model 1)}

In the first lactation after implementation of dry period length treatments, but not in the second lactation, cows with a 0 -d dry period had higher titer of $\operatorname{IgG}$ binding LPS in plasma compared with cows with a 60-d dry period (Table 4.1). Both in the first and second lactations after implementation of dry period length treatments, dry period length did not affect plasma NAb titers binding KLH or IgM binding LPS. In both lactations after implementation of dry period length and dietary treatments, ration did not affect NAb titers in plasma. There was an interaction between parity $\times$ ration for IgM binding KLH and LPS in the first lactation after implementation of dry period length treatments and IgG and IgM binding LPS in the second lactation (Figure 4.1). In short, older cows (parity $>3$ 
and parity $>4$ for the first and second lactations, respectively) fed the lipogenic diet had higher NAb titers in plasma, compared with older cows fed the glucogenic diet. On the contrary, younger cows (parity $\leq 3$ and parity 4 for the first and second lactations, respectively) fed the lipogenic diet had lower NAb titers in plasma, compared with younger cows fed the glucogenic diet.
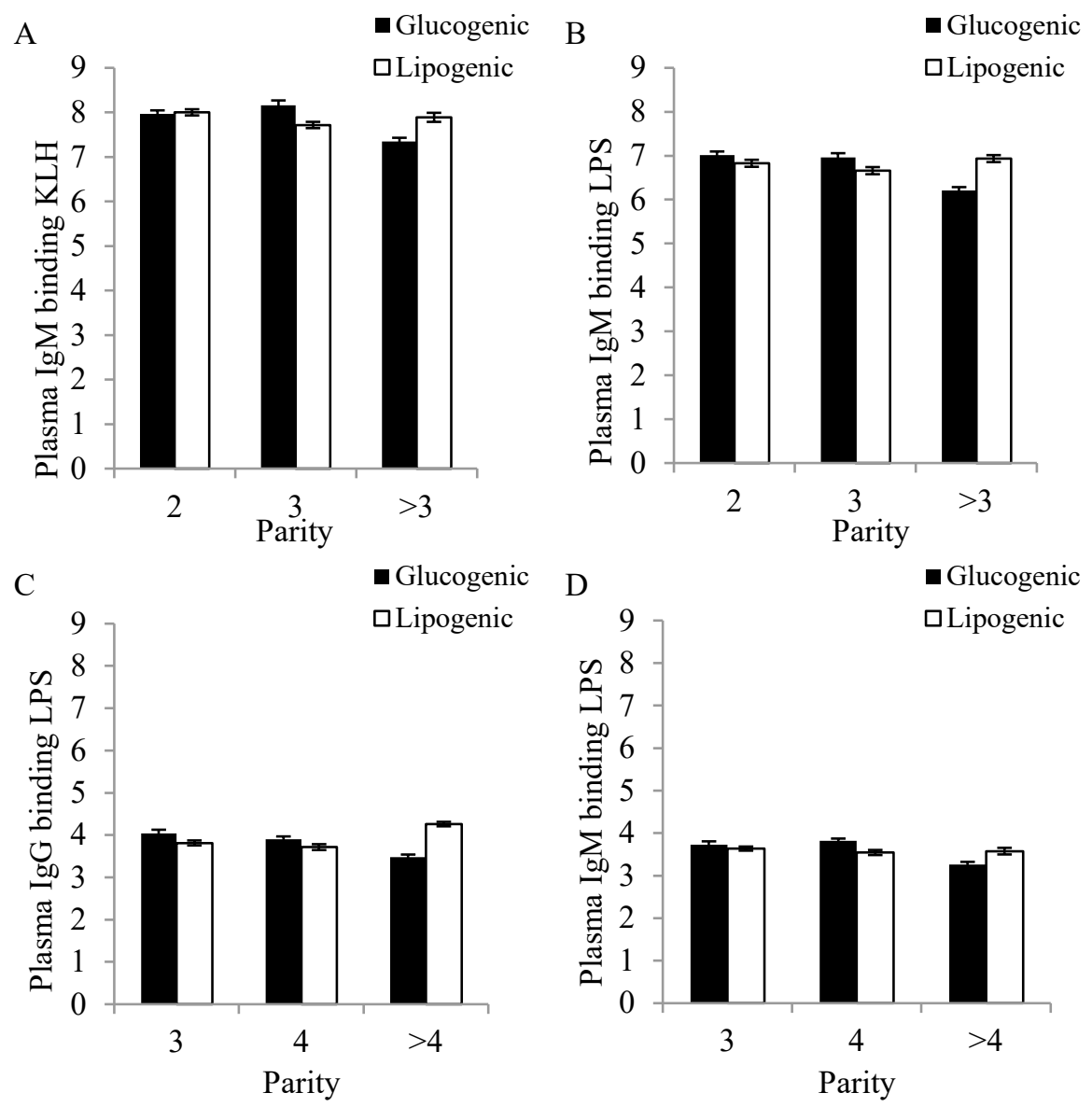

Figure 4.1 Plasma natural antibodies titers (IgG and IgM) binding keyhole limpet hemocyanin (KLH) and lipopolysaccharide (LPS) for cows from wk -3 till wk 9 relative to calving in the first lactation (A and B) and in second lactation (C and D) per ration per parity class. Values represent means per ration per parity class $( \pm$ SEM). 

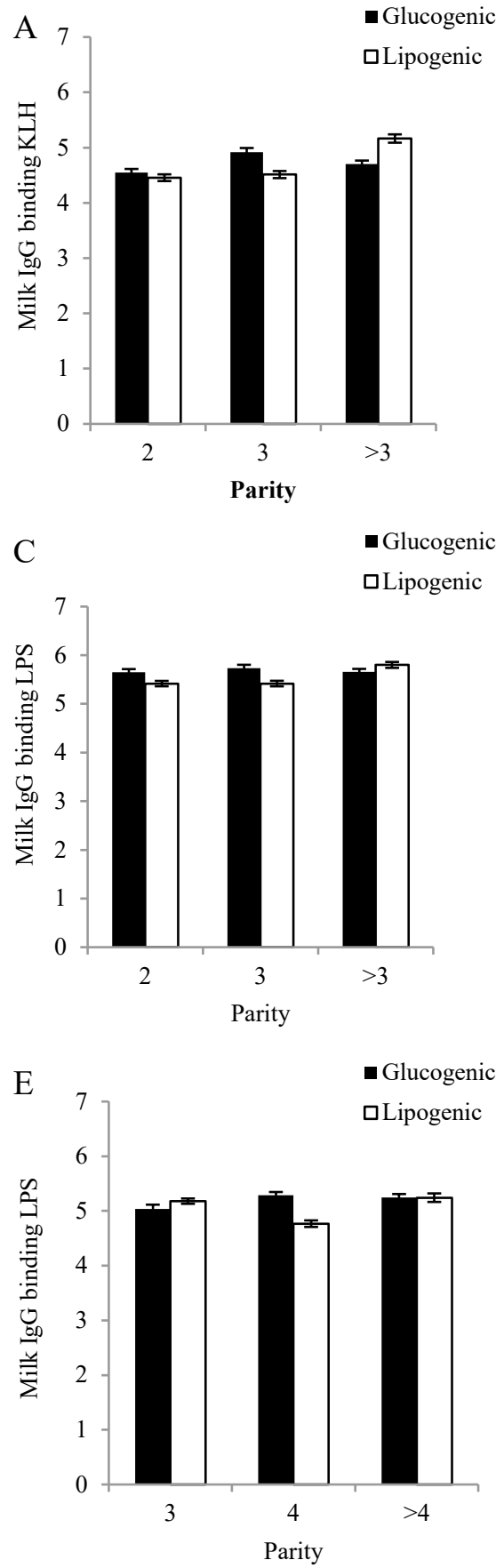
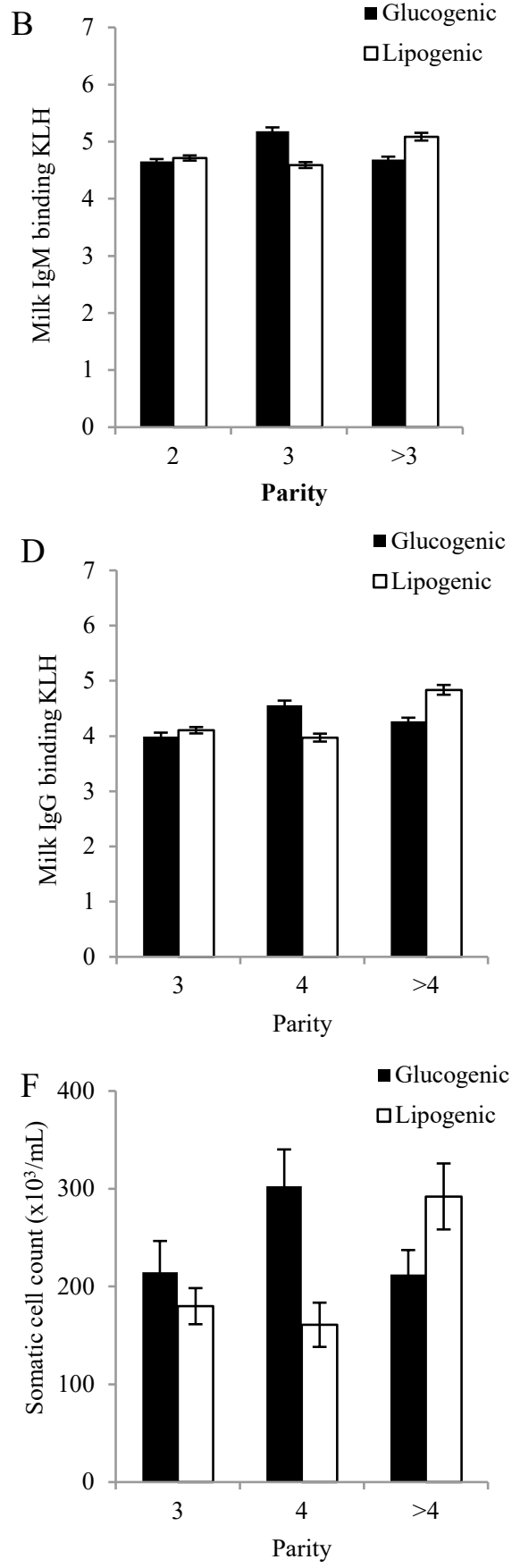

Figure 4.2 Milk natural antibodies titers (IgG and IgM) binding keyhole limpet hemocyanin (KLH) and lipopolysaccharide (LPS) for cows from week 1 till week 14 relative to calving in the first lactation (A, B and C) and in the second lactation (D and E), and somatic cell count in the second lactation after implementation of dry period length treatments $(F)$ per ration per parity class. Values represent means per ration per parity class $( \pm$ SEM). 


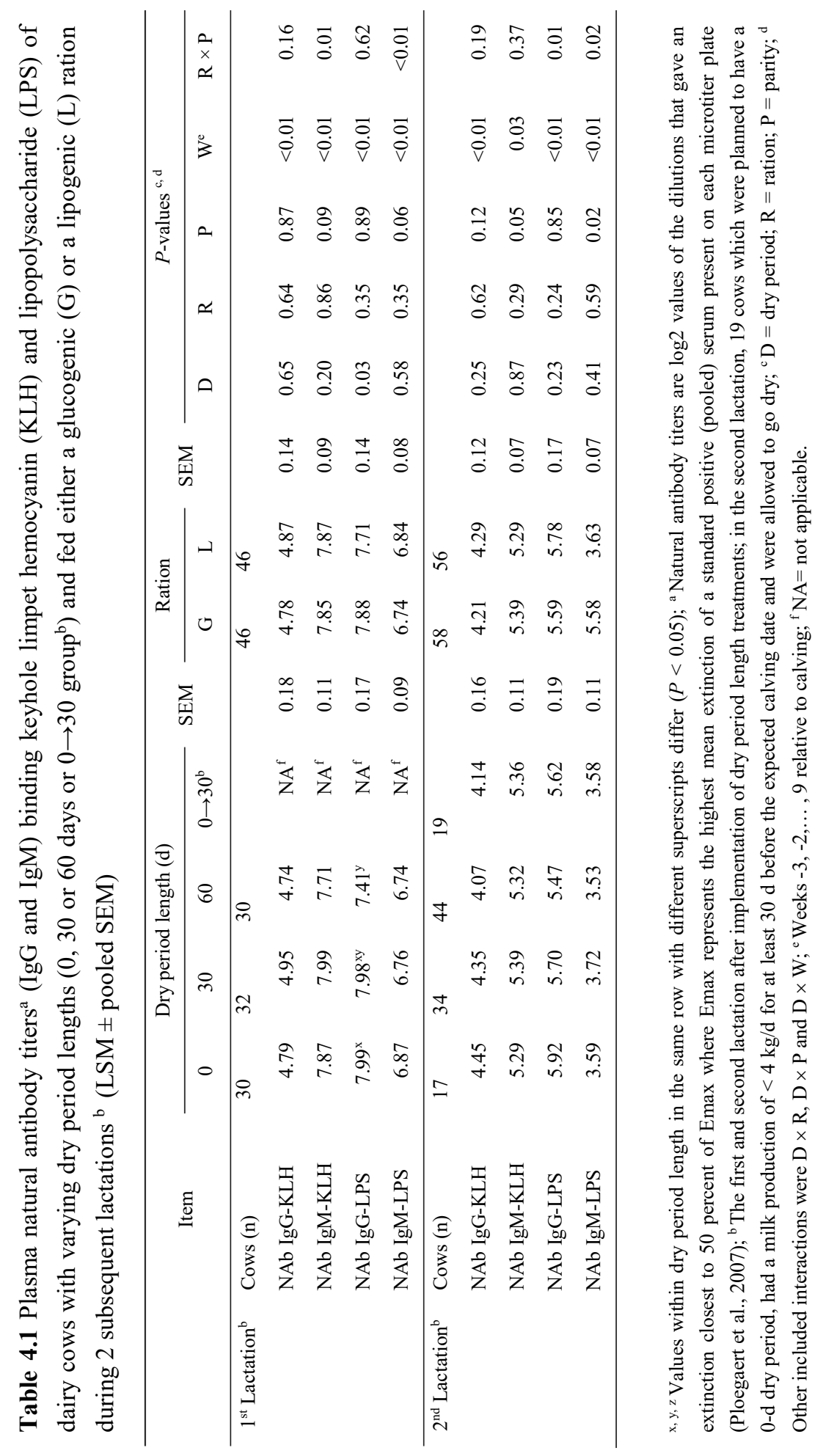



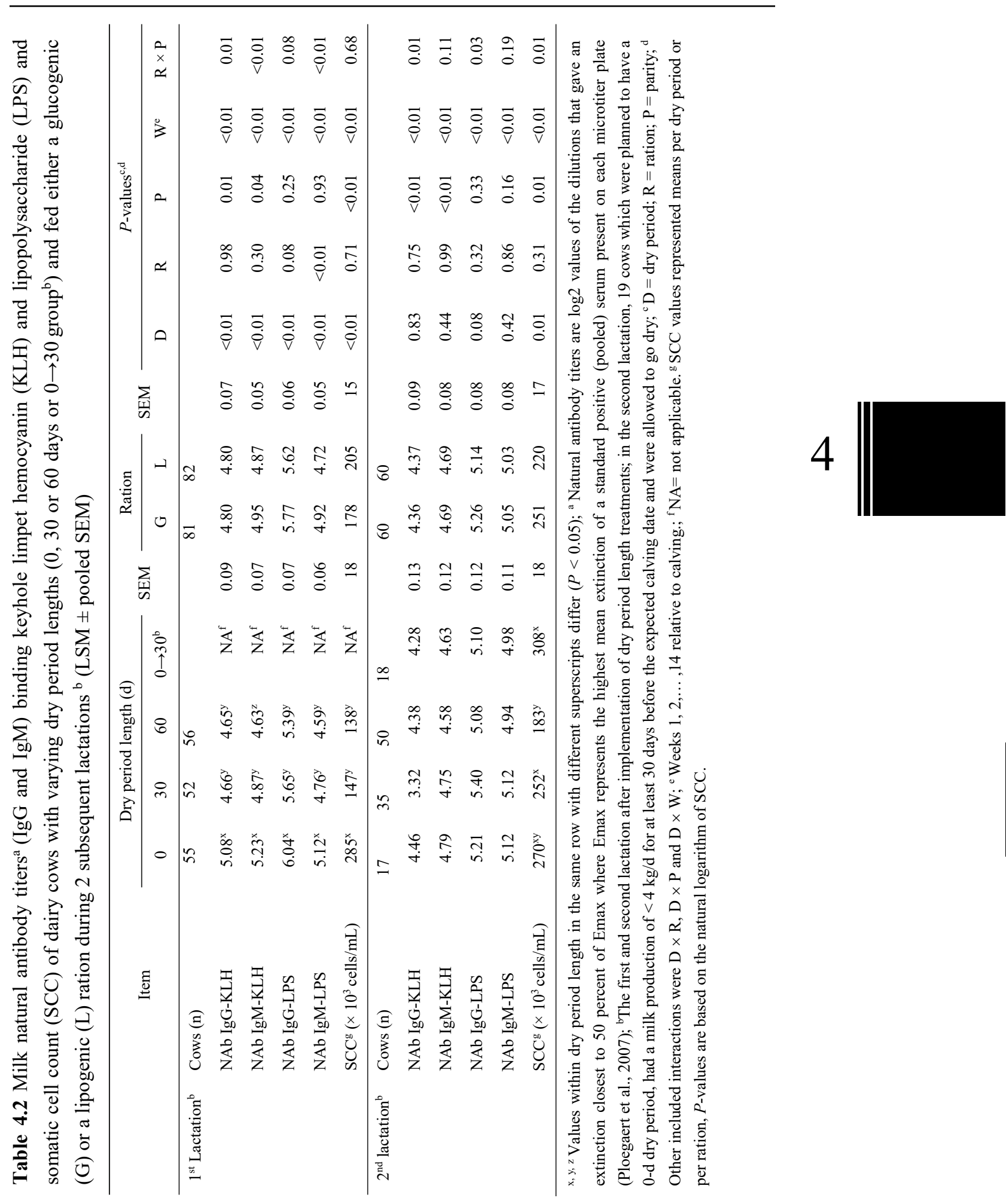


\subsubsection{Effects of Dry Period Length and Ration on Natural Antibodies in Milk (Model 1)}

In the first lactation after implementation of dry period length treatments, cows with a 0-d dry period had higher titers of IgG and IgM-binding KLH or LPS in milk compared with cows with a 30-d or a 60-d dry period (Table 4.2). In the second lactation after implementation of dry period length treatments, dry period treatment did not affect NAb titers in milk. In line with NAb titers in plasma, there was an interaction between parity $\times$ ration for $\operatorname{IgG}$ and $\operatorname{IgM}$ binding KLH and $\operatorname{IgG}$ binding LPS in the first lactation and IgG binding KLH and LPS in the second lactation (Figure 4.2). In short, older cows (parity $>3$ and parity $>4$ for the first and second lactations after implementation of dry period length and dietary treatments, respectively) fed the lipogenic diet had higher NAb titers in milk, compared with older cows fed the glucogenic diet. On the contrary, younger cows (parity $\leq 3$ and parity 4 for the first and second lactations after implementation of dry period length and dietary treatments, respectively) fed the lipogenic diet had lower NAb titers in milk, compared with younger cows fed the glucogenic diet.

\subsubsection{Effects of Dry Period Length and Ration on Somatic Cell Count and Clinical Mastitis (Model 2)}

In the first lactation after implementation of dry period length treatments, there were 71 out of 163 cows with high SCC and the average cases of high SCC per affected cow was 3.4 (from week -3 until 14 relative to calving). In the second lactation after implementation of dry period length treatments, there were 82 out of 120 cows with high SCC and the average cases of high SCC per affected cow is 4.3 (from week -3 until 14 relative to calving). In the first lactation after implementation of dry period length treatments, cows with a 0 -d dry period had a higher SCC in milk compared with cows with a $30-\mathrm{d}$ or a $60-\mathrm{d}$ dry period. In the second lactation after implementation of dry period length treatments, cows with a 60-d dry period had a lower SCC in milk, compared with cows with a 30-d or a 0 $\rightarrow 30-d$ dry period, but did not differ from cows with a 0-d dry period (Table 4.2). In the first and second lactations after implementation of dry period length and dietary treatments, there was no ration effect on SCC in milk. However, there was an interaction between parity $\times$ ration for SCC in the second lactation (Figure 4.2). A glucogenic ration resulted in a lower SCC in milk in older cows (parity $>4$ ), but resulted in a higher SCC in younger cows (parity $=4$ ). In the first lactation after implementation of dry period length treatments, the clinical mastitis occurrence 
was 17 percent (29 cows out of 167) and did not differ among dry period lengths or rations. In the second lactation after implementation of dry period length treatments, the clinical mastitis occurrence was 25 percent (32 cows out of 130) and did not differ among dry period lengths or rations. Eight cows had clinical mastitis occurrence in both first and second lactations after implementation of dry period length treatments ( 2 cows with a 0 -d dry period and glucogenic ration, 1 cow with a 30-d dry period and lipogenic ration, 1 cow with a 30-d dry period and glucogenic ration, 2 cows with a 60-d dry period and glucogenic ration, and 2 cows with a 60-d dry period and lipogenic ration).

Table 4.3 Effects of natural antibody ${ }^{\mathrm{a}}$ (NAb) titers (IgG and IgM) binding keyhole limpet hemocyanin $(\mathrm{KLH})$ and lipopolysaccharide (LPS) in plasma and milk on the odds of a high somatic cell count.

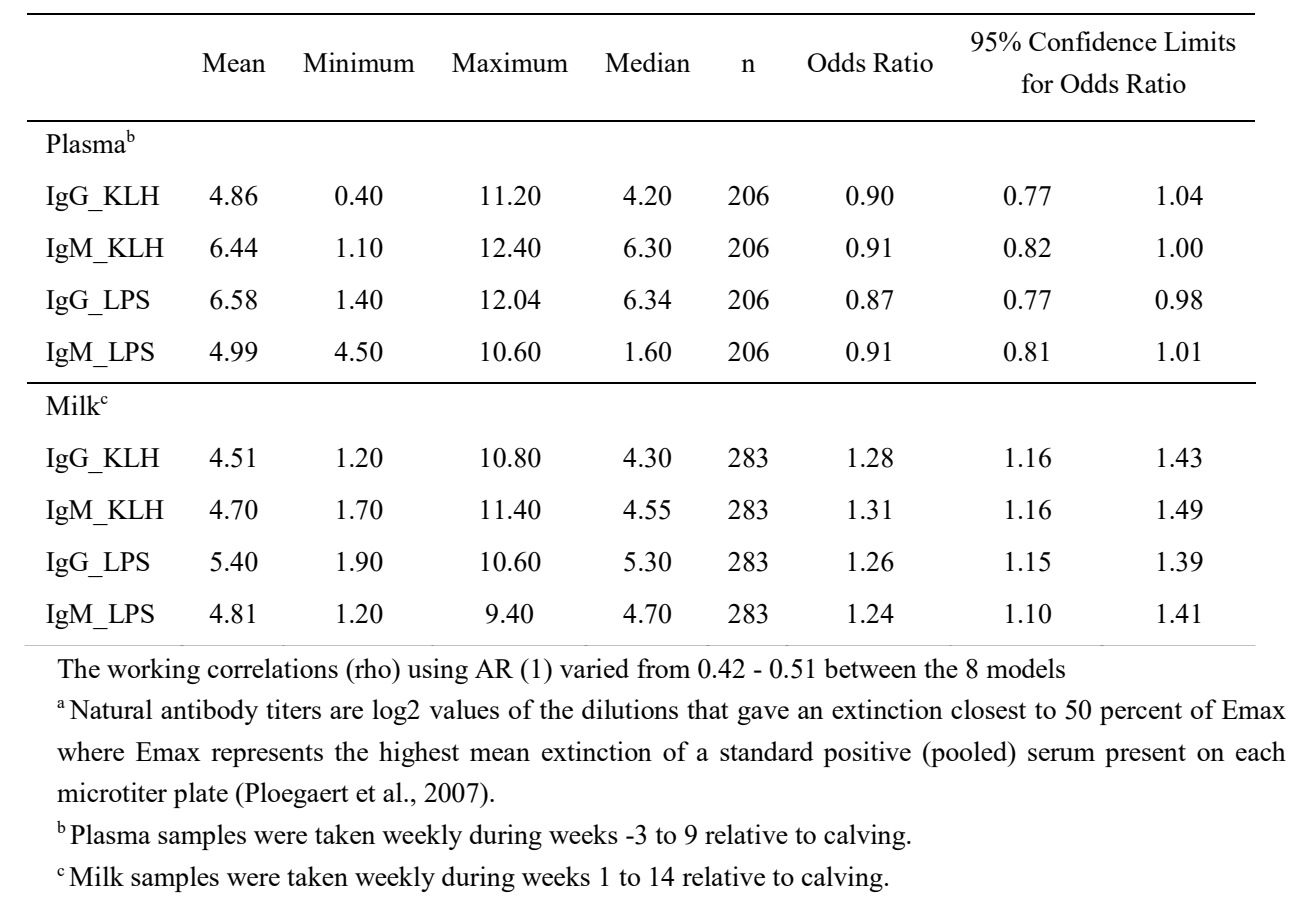




\subsubsection{Titers of Natural Antibodies and the Association with Somatic Cell Count and Clinical Mastitis (Model 3 and 4)}

All relationships between NAb titers and a high SCC or clinical mastitis occurrence were independent of dry period length. All odds ratios for NAb titers in plasma were $<1$ and for NAb titers in milk $>1$ (Table 4.3 and 4.4, Model 3). Increasing titers of IgM binding KLH and IgG binding LPS in plasma were associated with a decreased odds of a high SCC (Table 4.3). On the contrary, increasing titers of IgG and IgM binding KLH and LPS in milk were associated with an increased odds of high SCC. For clinical mastitis occurrence, increasing titer of IgG binding LPS in plasma was associated with a decreased odds of occurrence (Table 4.4). On the contrary, increasing titers of IgG and IgM binding $\mathrm{KLH}$ and LPS in milk were associated with a significantly increased odds of clinical mastitis occurrence.

A week before the occurrence of high SCC, increasing titer of IgM binding $\mathrm{KLH}$ in plasma was associated with a decreased odds of high SCC occurrence (Table 4.5, Model 4). Three weeks before the incidence of diseases, increasing titers of IgM binding KLH and LPS in plasma were associated with a decreased odds of clinical mastitis occurrence. A week before the incidence of disease, increasing titer of IgG binding LPS in plasma was associated with a decreased odds of clinical mastitis occurrence. 
Table 4.4 Effects of natural antibody ${ }^{\mathrm{a}}(\mathrm{NAb})$ titers (IgG and $\operatorname{IgM}$ ) binding keyhole limpet hemocyanin (KLH) and lipopolysaccharide (LPS) in plasma and milk on the odds of clinical mastitis occurrence.

\begin{tabular}{lcccccccc}
\hline & Mean & Minimum & Maximum & Median & $\mathrm{n}$ & Odds Ratio & $\begin{array}{c}\text { 95\% Confidence Limits } \\
\text { for Odds Ratio }\end{array}$ \\
\hline Plasma & & & & & & & & \\
IgG_KLH & 4.86 & 0.40 & 11.20 & 4.20 & 206 & 0.81 & 0.53 & 1.23 \\
IgM_KLH & 6.44 & 1.10 & 12.40 & 6.30 & 206 & 0.84 & 0.65 & 1.02 \\
IgG_LPS & 6.58 & 1.40 & 12.04 & 6.34 & 206 & 0.76 & 0.61 & 0.94 \\
IgM_LPS & 4.99 & 4.50 & 10.60 & 1.60 & 206 & 0.88 & 0.69 & 1.12 \\
\hline Milk & & & & & & & 1.04 & 1.48 \\
IgG_KLH & 4.51 & 1.20 & 10.80 & 4.30 & 283 & 1.24 & 1.04 & 1.64 \\
IgM_KLH & 4.70 & 1.70 & 11.40 & 4.55 & 283 & 1.30 & 1.03 & 1.62 \\
IgG_LPS & 5.40 & 1.90 & 10.60 & 5.30 & 283 & 1.32 & 1.08 & 1.63 \\
IgM_LPS & 4.81 & 1.20 & 9.40 & 4.70 & 283 & 1.28 & 1.01 & \\
\hline
\end{tabular}

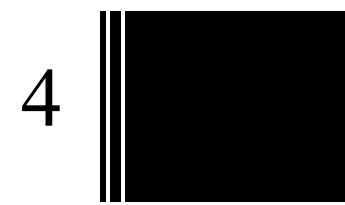

The working correlations (rho) using AR (1) varied from 0.28 - 0.37 between the 8 models

${ }^{a}$ Natural antibody titers are $\log 2$ values of the dilutions that gave an extinction closest to 50 percent of Emax where Emax represents the highest mean extinction of a standard positive (pooled) serum present on each microtiter plate (Ploegaert et al., 2007).

${ }^{\mathrm{b}}$ Plasma samples were taken weekly during weeks -3 to 9 relative to calving.

${ }^{\mathrm{c}}$ Milk samples were taken weekly during weeks 1 to 14 relative to calving. 
Table 4.5 Effects of natural antibody titers ${ }^{\mathrm{a}}$ (IgG and IgM) binding keyhole limpet hemocyanin (KLH) and lipopolysaccharide (LPS) in plasma in the 3 weeks before the occurrence of diseases on the odds of high somatic cell count (SCC) or clinical mastitis $(\mathrm{CM})$.

\begin{tabular}{|c|c|c|c|c|}
\hline & $\mathrm{N}$ & Odds Ratio & \multicolumn{2}{|c|}{$\begin{array}{l}\text { 95\% Confidence Limits } \\
\text { For Odds Ratio }\end{array}$} \\
\hline \multicolumn{5}{|c|}{1 week before high SCC occurrence } \\
\hline IgG_KLH & 206 & 0.94 & 0.82 & 1.02 \\
\hline IgM_KLH & 206 & 0.89 & 0.79 & 1.00 \\
\hline IgG_LPS & 206 & 0.91 & 0.81 & 1.01 \\
\hline IgM_LPS & 206 & 0.92 & 0.83 & 1.03 \\
\hline \multicolumn{5}{|c|}{2 weeks before high SCC occurrence } \\
\hline IgG_KLH & 206 & 0.96 & 0.84 & 1.10 \\
\hline IgM_KLH & 206 & 0.93 & 0.84 & 1.03 \\
\hline IgG_LPS & 206 & 0.93 & 0.83 & 1.04 \\
\hline IgM_LPS & 206 & 0.95 & 0.85 & 1.07 \\
\hline \multicolumn{5}{|c|}{3 weeks before high SCC occurrence } \\
\hline IgG_KLH & 206 & 1.03 & 0.90 & 1.18 \\
\hline IgM_KLH & 206 & 0.91 & 0.82 & 1.01 \\
\hline IgG_LPS & 206 & 0.94 & 0.84 & 1.04 \\
\hline IgM_LPS & 206 & 0.94 & 0.84 & 1.06 \\
\hline \multicolumn{5}{|c|}{1 week before $\mathrm{CM}$ occurrence } \\
\hline IgG_KLH & 206 & 0.86 & 0.66 & 1.12 \\
\hline IgM_KLH & 206 & 0.74 & 0.60 & 0.91 \\
\hline IgG_LPS & 206 & 0.83 & 0.70 & 0.99 \\
\hline IgM_LPS & 206 & 0.81 & 0.67 & 0.97 \\
\hline \multicolumn{5}{|c|}{2 weeks before $\mathrm{CM}$ occurrence } \\
\hline IgG_KLH & 206 & 0.83 & 0.62 & 1.12 \\
\hline IgM_KLH & 206 & 0.78 & 0.64 & 0.93 \\
\hline IgG_LPS & 206 & 0.86 & 0.70 & 1.09 \\
\hline IgM_LPS & 206 & 0.81 & 0.66 & 1.00 \\
\hline \multicolumn{5}{|c|}{3 weeks before $\mathrm{CM}$ occurrence } \\
\hline IgG_KLH & 206 & 1.05 & 0.79 & 1.38 \\
\hline IgM_KLH & 206 & 0.71 & 0.56 & 0.90 \\
\hline IgG_LPS & 206 & 0.87 & 0.69 & 1.10 \\
\hline IgM_LPS & 206 & 0.81 & 0.66 & 0.99 \\
\hline
\end{tabular}




\subsection{Discussion}

The current study demonstrates that in the first lactation after implementation of dry period length treatments, cows with a 0-d dry period had higher titers of IgG binding LPS in plasma, and higher titers of IgG and IgM binding KLH or LPS in milk compared with cows with a 60-d dry period. In addition, parity 2 cows fed a glucogenic ration had higher titer of IgM binding LPS in milk, and tended to have higher titers of IgG binding LPS in milk compared with cows fed a lipogenic ration in early lactation. In a previous study, higher titers of NAb binding KLH in plasma were associated with a less negative EB in dairy cows in early lactation (Van Knegsel et al., 2007). In this earlier work, the less negative EB was related to feeding the cows a more glucogenic ration, compared with a lipogenic ration. In the current experiment, cows had improved EB both by feeding a glucogenic ration and by shortening or omitting the dry period, as earlier reported (Van Knegsel et al., 2014). Specifically, omitting the dry period resulted in a less negative EB in the subsequent lactation as a consequence of lower daily milk yield at a similar dry matter intake (DMI).

Hence, it can be suggested that the higher NAb titers for cows in plasma and in milk with no dry period in the first lactation after implementation of dry period length treatments are related with the improved EB and reduced milk yield in these cows. In the second lactation after implementation of dry period length treatments, cows with no dry period had similar NAb levels in plasma and in milk as cows with a dry period of 30-d or 60-d. Moreover, in the second lactation after implementation of dry period length treatments, cows with no dry period had less pronounced improvement of EB and had less milk yield losses compared with the first after implementation of dry period length and dietary treatments (Chen et al., 2015).

Omitting the dry period not only results in a less negative EB, but is also known to result in an increased SCC in milk in the subsequent lactation (Annen et al., 2004, Klusmeyer et al., 2009). Also in the current study, cows with a 0-d dry period had a higher SCC in milk, compared with cows with a $30-d$ or a $60-d$ dry period. In a previous study, a high SCC due to omitting the dry period was associated with a reduced milk yield, resulting in a reduced diluting effect (Steeneveld et al., 2013). Also in the current study, incorporating daily milk yield as a covariate in the statistical model reduced the effect of dry period length on the SCC (Van Knegsel et al., 2014). This means that the effect of length of the dry period on SCC is partly explained by a reduced diluting effect (Van Knegsel 
et al., 2014).

Somatic cell count has been related previously to titers of IgM binding KLH or LPS in milk (Ploegaert, 2010). In the current study, the odds ratios of NAb titers in milk for the relative odds of a high SCC were all greater than 1. This suggests that increasing titers of IgG and IgM-binding KLH or LPS in milk are associated with an increased odds of a high SCC. In contrast, increasing titers of IgM binding KLH and IgG binding LPS in plasma were associated with a decreased odds of a high SCC. A high SCC and increased levels of antibodies in milk may both rest on increased vascular permeability after intramammary inflammation (Korhonen et al., 2000). In addition, $\mathrm{Fc}$ receptor mediated transfer for IgG and IgM was detected for mammary gland polymorphonuclear neutrophils in dairy cows (Lascelles, 1979, Hurley and Theil, 2011). The other suggested mechanism that results in a high level of NAb in milk might be that immunoglobulins are produced locally by lymphocytes located near the glandular epithelium (Lascelles, 1979, Persson et al., 1992).

In the current study, increasing NAb levels in milk were associated with increased odds of high SCC and clinical mastitis occurrence, which is in line with earlier work (Ploegaert, 2010). Moreover, the current study shows that specific high NAb in plasma are associated with a decreased odds of clinical mastitis occurrence. A previous study reported that increasing titer of IgM binding KLH in plasma was associated with a decreased odds of clinical mastitis occurrence (unadjusted odds ratio $=0.958$ ) (Thompson-Crispi et al., 2013). In the current study, the odds ratio for IgM binding KLH in plasma is in line with that of this earlier work (odds ratio $=0.81)$, but not statistically different from $1(95 \%$ confidence interval $=0.60$ to 1.02 ), which is possibly consequence of low statistical power. It has been suggested that the level of NAb in plasma or milk may be an additional variable to select for mastitis resistance in dairy cows (Ploegaert, 2010, Thompson-Crispi et al., 2013).

It can be questioned whether an increase in the level of NAb in plasma or milk relates only to past or present intramammary inflammation, or could also act as an indicator for future mammary infections. Therefore, the high SCC and clinical mastitis occurrence was associated with the levels of NAb in plasma or milk in the 3 weeks before the high SCC and clinical mastitis occurrence. Increasing plasma NAb titer for IgM binding KLH in the week before the occurrence of high SCC were associated with a decreased odds of high SCC occurrence. Moreover, increasing titers of IgM binding KLH or LPS in plasma in 
the 3 weeks before the incidence of the disease was associated with decreased odds of clinical mastitis occurrence. Further studies are needed to confirm these relationships and study the possible value of NAb's as early indicators for reduced mammary health in dairy cows.

In the current study, although the dry period length did affect SCC in milk, the dry period length did not affect clinical mastitis occurrence. From an earlier study, it was concluded that applying a 0 -d dry period may impose a greater odds of a high SCC because cows are not treated with long-acting intramammary antibiotics, although it lowered the odds of new infections during the dry period (Annen et al., 2004, Collier et al., 2012). Furthermore, other studies reported no differences in the clinical mastitis occurrence between cows with a short dry period and cows with a conventional dry period (Enevoldsen and Sørensen, 1992, Watters et al., 2008, Shoshani et al., 2014). This might imply that omitting and shortening the dry period affects SCC, but not clinical mastitis occurrence.

In contrast to earlier work, the current study monitored the cows for 2 subsequent lactations after a shortened or omitted dry period. The results for the second lactation after implementation of dry period length treatments differed from those of the first lactation after implementation of dry period length treatments for several aspects. Firstly, in contrast to the first lactation, in the second lactation after implementation of dry period length treatments dry period length had no effect on NAb titers in plasma and milk. This might be due to reduced differences in milk yield, and reduced differences in EB between dry period lengths in the second lactation (Chen et al., 2016). Secondly, the average parity of the cows in the second lactation was greater than that in the first lactation. Earlier studies showed that older cows have higher NAb titers (Van Knegsel et al., 2007), and milk yield losses due to shorter dry periods are smaller than for younger cows (Van Knegsel et al., 2014). Thirdly, after the first lactation after implementation of dry period length treatments, some cows that were planned for a 0-d dry period, dried off naturally, and were allocated to the $0 \rightarrow 30-\mathrm{d}$ dry period group. In contrast to cows with a $30-\mathrm{d}$ or 60 -d dry period, cows with a $0 \rightarrow 30-d$ dry period were not treated with an intramammary antibiotic at the time of drying off. Although different dry-off protocols were used for the $0 \rightarrow 30-\mathrm{d}$ and the $30-\mathrm{d}$ dry period, the SCC was not statistically different between cows with a 30 -d and a $0 \rightarrow 30$-d dry period. Similar SCC levels in the second lactation between the groups might be due to small or zero differences in milk yield for different dry period groups. 
Earlier studies showed that older cows have a higher SCC than younger cows (Annen et al., 2004, Steeneveld et al., 2013), which is in line with the current study for both lactations. However, cows with parity $>4$ in the second lactation had a lower SCC when they were fed a glucogenic ration compared with a lipogenic ration. In the current study parity $\times$ ration interaction not only affected the SCC, but also NAb titers. Earlier studies showed that higher NAb titers binding KLH in plasma increased with parity (Van Knegsel et al., 2007), and are higher in adult cows than in calves (Srinivasan et al., 1999). Exogenous factors or environmental stimuli enhance NAb development (Prokešová et al., 1996), and therefore might explain an increase in NAb titers with age.

The current study implies that, compared with the first lactation after implementation of dry period length and dietary treatments, the effects on NAb titers and mammary health by shortening or omitting the dry period are different in the second lactation after implementation of dry period length and dietary treatments. As discussed above, in response to dry period length treatment in both lactations, differences in EB, milk yield, DMI level and parity may underlie differences in mammary health and NAb titers. Further studies are required to study the life-long effects on mammary health of dairy cows by shortening or omitting the dry period. Moreover, results of this study indicate that IgM-binding KLH in plasma can be an early predictor of clinical mastitis occurrence in dairy cows. At the moment, studies are ongoing aiming at identification of factors that predict mammary health after a shortened or omitted dry period in dairy cows.

\subsection{Conclusions}

Cows with a 0-d dry period had higher SCC, higher NAb titers for isotypes IgG and IgM in milk, and higher titer of IgG-binding LPS in plasma compared with cows with a $30-\mathrm{d}$ or $60-\mathrm{d}$ dry period in the first lactation after implementation of dry period length. However, after repeated shortening or omitting the dry period, the effects of omitting the dry period on NAb titers in plasma and milk disappeared. In addition, increasing titers of NAb-binding KLH or LPS in milk for both lactations were associated with increased odds of a high SCC and increased odds of clinical mastitis occurrence. In contrast, increasing titers of IgM binding $\mathrm{KLH}$ and IgG binding LPS in plasma for both the first and second lactations after implementation of dry period length and dietary treatments were associated with decreased odds of a high SCC and decreased odds of clinical mastitis occurrence. Titer of IgM binding KLH in plasma in a week and in all 3 weeks before the 
incidence of disease were associated with high SCC and clinical mastitis occurrence, respectively. This implies that IgM binding KLH in plasma can be an early predictor of high SCC and clinical mastitis occurrence in dairy cows.

\subsection{Acknowledgements}

The authors wish to thank the Dutch Dairy Board (PZ, Zoetermeer, the Netherlands), the Product Board Animal Feed (PDV, Zoetermeer, the Netherlands), and CRV (Arnhem, the Netherlands), for financing the experiment. The authors also wish to acknowledge their thanks for the scholarship of Novi Mayasari from the Directorate General of Higher Education, Ministry of National Education, Jakarta, Indonesia. The authors thank Danny De Koning for his help during statistical analysis and Joop Arts, Mike Nieuwland, and the staff of the Dairy Campus (Lelystad, the Netherlands) for their technical support during the experiment and the laboratory analysis.

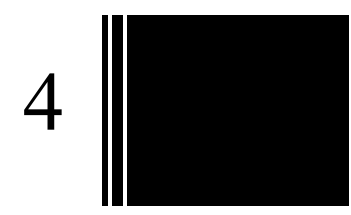




\section{References}

Akaike, H., 1974. A new look at the statistical model identification. Autom. Control, IEEE Transactions. 19:716-723.

Annen, E. L., Collier, R. J., McGuire, M. A., Vicini, J. L., Ballam, J. M., Lormore, M. J., 2004. Effect of modified dry period lengths and bovine somatotropin on yield and composition of milk from dairy cows. J. Dairy Sci. 87:3746-3761.

Avrameas, S., 2006. Historical background of the invention of EIA and ELISA. Clin. Chem. 52:1430-1431.

Bernier-Dodier, P., Girard, C. L., Talbot, B. G., Lacasse, P., 2011. Effect of dry period management on mammary gland function and its endocrine regulation in dairy cows. J. Dairy Sci. 94:4922-4936.

Casali, P., Notkins, A. L., 1989. CD5+ B lymphocytes, polyreactive antibodies and the human B-cell repertoire. Immunol. Today. 10:364-368.

Collier, R. J., Annen-Dawson, E. L., Pezeshki, A., 2012. Effects of continuous lactation and short dry periods on mammary function and animal health. Animal. 6:403-414.

Chen, J., Gross, J.J., van Dorland, H.A., Remmelink, G.J., Bruckmaier, R.M., Kemp, B., van Knegsel, A.T.M., 2015. Effects of dry period length and dietary energy source on metabolic status and hepatic gene expression of dairy cows in early lactation. J. Dairy Sci. 98:1033-1045.

Chen, J., Remmelink, G.J., Gross, J.J., Bruckmaier, R.M., Kemp, B., van Knegsel, A.T.M., 2015. Effects of dry period length and dietary energy source on milk yield, energy balance, and metabolic status of dairy cows over 2 consecutive years: effects in the second year J. Dairy Sci. 99:4826-4838.

Enevoldsen, C., Sørensen, J. T., 1992. Effects of dry period length on clinical mastitis and other major clinical health disorders. J. Dairy Sci. 75:1007-1014.

Hurley, W. L., Theil, P. K., 2011. Perspectives on immunoglobulins in colostrum and milk. Nutrients 3:442-474.

Klusmeyer, T. H., Fitzgerald, A. C., Fabellar, A. C., Ballam, J. M., Cady, R. A., Vicini, J. L., 2009. Effect of recombinant bovine somatotropin and a shortened or no dry period on the performance of lactating dairy cows. J. Dairy Sci. 92:5503-5511.

Kohler, H., Bayry, J., Nicoletti, A., Kaveri, S. V., 2003. Natural autoantibodies as tools to predict the outcome of immune response? Scand. J. Immun. 58:285-289.

Köpf, M., Gellrich, K., Küchenhoff, H., Meyer, H. H. D., Kliem, H., 2014. Effects of continuous milking during a field trial on productivity, milk protein yield and health in dairy cows. Animal 8:1130-1138.

Korhonen, H., Marnila, P., Gill, H. S., 2000. Milk immunoglobulins and complement factors. Br. J. Nutr. 84:75-80.

Lascelles, A. K., 1979. The immune system of the ruminant mammary gland and its role in the control of mastitis. J. Dairy Sci. 62:154-160.

Littell, R. C., Milliken, G. A., Stroup, W. W., Wolfinger, R. D., 1996. SAS system for mixed models. SAS Institute, Cary, NC, USA.

Matter, M. S., Ochsenbein, A. F., 2008. Natural antibodies target virus-antibody complexes to organized lymphoid tissue. Autoimmun. Rev. 7:480-486.

Ochsenbein, A. F., Fehr, T., Lutz, C., Suter, M., Brombacher, F., Hengartner, H., Zinkernagel, R. M., 1999. Control of early viral and bacterial distribution and disease by natural antibodies. Science 286:2156-2159. 
Ochsenbein, A. F., Zinkernagel, R. M., 2000. Natural antibodies and complement link innate and acquired immunity. Immunol. Today 21:624-630.

Persson, K., Carlsson, Å., Hambleton, C., Guidry, A. J., 1992. Immunoglobulins, lysozyme and lactoferrin in the teat and udder of the dry cow during endotoxininduced inflammation. J. Vet. Med. Ser. 39:165-174.

Ploegaert, T.C.W., Reilingh, G.D.V., Nieuwland, M.G.B., Lammers, A., Savelkoul, H.F.J., Parmentier, H.K., 2007. Intratracheally administered pathogenassociated molecular patterns affect antibody responses of poultry. Poultry Sci. $86: 1667-1676$.

Ploegaert, T., 2010. Parameters for natural resistance in bovine milk. PhD dissertation. Wageningen University, Wageningen, the Netherlands.

Prokešová, L., Tučková, L., Cukrowska, B., Tlaskalová-Hogenová, H., Barot-Ciorbaru, R., 1996. Occurrence and specificity of human natural and in vitro induced antibodies to Nocardia opaca antigens. Int. J. Immunopharmacol. 18:661-668.

Rastani, R. R., Grummer, R. R., Bertics, S. J., Gümen, A., Wiltbank, M. C., Mashek, D. G., Schwab, M. C., 2005. Reducing dry period length to simplify feeding transition cows: milk production, energy balance, and metabolic profiles. J. Dairy Sci. 88:1004-1014

Santman-Berends, I.M.G.A., Olde Riekerink, R.G.M., Sampimon, O.C., van Schaik, G., Lam, T.J.G.M., 2012. Incidence of subclinical mastitis in Dutch dairy heifers in the first 100 days in lactation and associated risk factors. J. Dairy Sci. 95:24762484.

Schlamberger, G., Wiedemann, S., Viturro, E., Meyer, H.H., Kaske, M., 2010. Effects of continuous milking during the dry period or once daily milking in the first 4 weeks of lactation on metabolism and productivity of dairy cows. J. Dairy Sci. 93:2471-2485.

Shoshani, E., Rozen, S., Doekes, J. J., 2014. Effect of a short dry period on milk yield and content, colostrum quality, fertility, and metabolic status of Holstein cows. J. Dairy Sci. 97:2909-2922.

Srinivasan, A., Ni, Y., Tizard, I., 1999. Specificity and prevalence of natural bovine antimannan antibodies. Clin. Diagn. Lab. Immunol. 6:946-952.

Steeneveld, W., Schukken, Y. H., van Knegsel, A. T. M., Hogeveen, H., 2013. Effect of different dry period lengths on milk production and somatic cell count in subsequent lactations in commercial Dutch dairy herds. J. Dairy Sci. 96:29883001 .

Tamminga, S., Van Straalen, W. M., Subnel, A. P. J., Meijer, R. G. M., Steg, A., Wever, C. J. G., Blok, M.C., 1994. The Dutch protein evaluation system: The DVE/OEB system. Livest. Prod. Sci. 40:139-155.

Thompson-Crispi, K. A., Miglior, F., Mallard, B. A., 2013. Genetic parameters for natural antibodies and associations with specific antibody and mastitis in Canadian Holsteins. J. Dairy Sci. 96:3965-3972.

Van Es, A. J. H., 1975. Feed evaluation for dairy cows. Livest. Prod. Sci. 4:95-107.

Van Knegsel, A. T. M., de Vries Reilingh, G., Meulenberg, S., van den Brand, H., Dijkstra, J., Kemp, B., Parmentier, H. K., 2007. Natural antibodies related to energy balance in early lactation dairy cows. J. Dairy Sci. 90:5490-5498.

Van Knegsel, A. T. M., Hostens, M., de Vries Reilingh, G., Lammers, A., Kemp, B., Opsomer, G., Parmentier, H. K., 2012. Natural antibodies related to metabolic and mammary health in dairy cows. Prev. Vet. Med. 103:287-297. 
Van Knegsel, A. T. M., Remmelink, G. J., Jorjong, S., Fievez, V., Kemp, B., 2014. Effect of dry period length and dietary energy source on energy balance, milk yield, and milk composition of dairy cows. J. Dairy Sci. 97:1499-1512.

Vollmers, H. P., Brändlein, S., 2009. Natural antibodies and cancer. New Biotech. 25:294298.

Watters, R. D., Guenther, J. N., Brickner, A. E., Rastani, R. R., Crump, P. M., Clark, P. W., Grummer, R. R., 2008. Effects of dry period length on milk production and health of dairy cattle. J. Dairy Sci. 91:2595-2603.

Zinkernagel, R. M., 2012. Immunological memory $\neq$ protective memory. Cell. Mol. Life. Sci. 69:1635-1640. 


\title{
CHAPTER 5
}

\author{
Effect of maternal dry period length on colostrum \\ immunoglobulin content, and natural \\ and specific antibody titers in calves
}

N. Mayasari* ${ }^{*}$, G. de Vries Reilingh*, M. G. B. Nieuwland*, G. J. Remmelink ${ }^{\ddagger}$ H. K. Parmentier*, B. Kemp* , A. T. M. van Knegsel*

"Adaptation Physiology Group, Department of Animal Science, Wageningen University, P.O. Box 338, 6700 AH Wageningen, the Netherlands; 'Faculty of Animal Husbandry, Universitas Padjadjaran, 45363, Bandung, Indonesia;

Livestock Research, Wageningen University and Research Centre, P.O. Box 338, 6700 AH Wageningen, the Netherlands

Journal of Dairy Science (2015) 98:3969-3979

DOI: $10.3168 /$ jds.2014-8753 


\subsection{Abstract}

The objective was to study the effect of dry period length in dairy cows on immunoglobulin content and natural antibodies (NAb) titers in colostrum, growth and plasma natural and specific antibody titers in plasma of calves. HolsteinFriesian dairy cows $(\mathrm{N}=167)$ were randomly assigned to 3 dry period lengths $(0$, 30 or $60 \mathrm{~d}$ ). Colostrum production, concentration of colostrum IgG and IgM, and titers of $\mathrm{NAb}$ (isotypes IgG and IgM) binding keyhole limpet hemocyanin (KLH) and human serum albumin (HuSA) in colostrum were measured. Female calves were immunized with both KLH and HuSA in week 6 and 10 of life. Titers of NAb and specific antibody (SpAb) for isotypes IgG, IgM and total immunoglobulin (IgT) binding KLH or HuSA were determined in plasma of female calves. Primary and secondary antibody responses to KLH or HuSA from week 6 and 10 were expressed as the increase in antibody titers to week 10 and 11 of life after primary and secondary challenges, respectively. Pregnancy length for cows with a $0-\mathrm{d}$ dry period was $3 \mathrm{~d}$ shorter, compared with cows with a 30-d or a 60-d dry period. Birth weight of calves from cows with a 0-d dry period was lower compared with calves from cows with a 30-d dry period. Growth of calves until 12 weeks of life was not affected by dry period length. Colostrum production and $\operatorname{IgG}$ and $\operatorname{IgM}$ concentration in colostrum were lower for cows with a 0-d dry period than a 60-d dry period. Natural IgG and IgM titers binding KLH or HuSA were lower in colostrum from cows with a 0-d dry period compared with cows with a 30-d or a 60 -d dry period. Natural antibody titers (IgG, IgM and IgT) binding KLH or HuSA in plasma were lower during the first 2 weeks of life for calves from cows with a 0 $\mathrm{d}$ dry period compared with calves from cows with a 30-d or 60-d dry period. After primary and secondary immunization of calves with KLH and HuSA, SpAb titers of calves were not affected by dry period length. After secondary immunization the response of IgG and IgT binding KLH was higher in plasma of calves from cows with a 0-d dry period. The results of this study demonstrate that although omission of the dry period of dairy cows leads to lower plasma NAb titers in calves during the first 2 weeks of life, SpAb titers in calves were not affected and even the secondary antibody responses were enhanced, compared with calves from cows with a 30 - or 60-d dry period.

Key words: continuous milking, colostrum, antibodies, calf. 


\subsection{Introduction}

Omission of the dry period of cows results in better energy balance (EB), and metabolic health in the next lactation (Andersen et al., 2005, Rastani et al., 2005). Omission of the dry period is controversial because of a potential decrease in milk production in the subsequent lactation (Annen et al., 2004, Santschi et al., 2011a). A meta-analysis including 24 randomized controlled trials (Van Knegsel et al., 2013) reported that shortening or omitting the dry period reduced milk production and increased milk protein content. In addition, shortening the dry period tended to reduce the incidence of ketosis in the subsequent lactation. Earlier studies showed that shortening the dry period to 4 weeks did not affect colostrum immunoglobulin content (Annen et al., 2004, Klusmeyer et al., 2009, Rastani et al., 2005, Watters et al., 2008), pregnancy length (Santschi et al., 2011b) and birth weight of calves (Pezeshki et al., 2007, Rastani et al., 2005), compared with a dry period of 8 weeks. Omission of the dry period, however, reduced colostrum immunoglobulin content (Annen et al., 2004, Klusmeyer et al., 2009, Rastani et al., 2005, Verweij et al., 2014), which may affect the immune competence of the calf. Adequate and sufficient passive immune transfer of maternal antibodies via colostrum intake may improve the immune competence of calves, and would reduce the risk of diseases and infections during the pre-weaning period (Oliveira

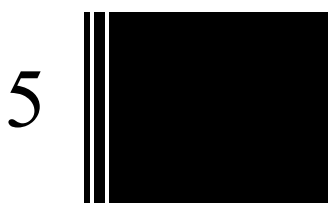
et al., 2010).

Natural antibodies (NAb) may play an important role in the development of immune competence. Natural antibodies are part of the innate immune system (Matter and Ochsenbein, 2008, Vollmers and Brändlein, 2009) and can be defined as antibodies present in healthy animals under the absence of antigen stimulation (Avrameas, 1991, Baumgarth et al., 2005) as opposed to specific antibodies (SpAb) that are raised to antigens after immunization. Natural antibodies are polyreactive with low affinity binding with various antigens (Casali and Notkins, 1989). Natural antibodies link innate and adaptive immunity, since they target antigens to the splenic marginal zone enhancing T-cell and T-cell dependent antibody responses (Matter and Ochsenbein, 2008), and activate complement activity. Zinkernagel (2012) proposed that NAb form an important protection for resistance to infection. In chickens, NAb binding Megathura crenulata-derived keyhole limpet hemocyanin (KLH) were related to a higher probability of survival during the laying period (Star et al., 2007, Sun et al., 2011). In mammals (Ochsenbein et al., 1999, Thornton et al., 1994, Tomer and Shoenfeld, 1988) and birds (Lammers et al., 2004, Parmentier et al., 2004), various specific humoral 
immune responses are enhanced by high NAb titers or are positively correlated with high NAb titers. On the other hand, high NAb levels might interfere with or prevent subsequent SpAb responses (Parmentier et al., 2008), whereas low NAb levels might facilitate or initiate higher SpAb responses (Sinyakov et al., 2002).

Natural antibodies were found in plasma of newborn calves (Srinivasan et al., 1999). In dairy cows, calves obtain maternal antibodies passively from the dam through colostrum. Natural antibodies in plasma of newborn calves were lower than in adult cows (Srinivasan et al., 1999) and NAb titers differ widely among adults (Ploegaert et al., 2011, Srinivasan et al., 1999). In addition, titers of NAb binding KLH or lipopolysaccharide (LPS) were related to the EB of dairy cows in early lactation (Van Knegsel et al., 2007). Knowledge on the effect of shortening or omitting the dry period of dairy cows on NAb in colostrum and the consequences for immune competence and development of calves is, however, absent.

As calves obtain passive immunity via colostrum, it was hypothesized that management or dietary strategies that affect immunoglobulin content in colostrum may affect immune competence of calves. The first objective of the present study was to evaluate the effect of dry period length in dairy cows on immunoglobulin content and NAb titers in colostrum, and growth and plasma NAb and SpAb titers of calves. The second objective was to study the responses of total immunoglobulin (IgT), and the isotypes $\operatorname{IgG}$ and IgM binding KLH and human serum albumin (HuSA) after primary and secondary immunization in these calves at week 6 and 10 , respectively.

\subsection{Materials and Methods}

\subsubsection{Experimental Design, Animals and Colostrum Sampling}

The Institutional Animal Care and Use Committee of Wageningen University approved the experimental protocol. Holstein-Friesian dairy cows $(\mathrm{N}=$ 167) were selected from the Dairy Campus Research dairy herd (WUR Livestock Research, Lelystad, the Netherlands), blocked for parity, calving date, milk yield and BCS, and randomly assigned to treatments. Cows enrolled in our study were clinically healthy and had SCC in milk $<250 \times 10^{3}$ cell $/ \mathrm{mL}$. Treatments consisted of 3 dry period lengths: 0,30 or $60 \mathrm{~d}$ and 2 early lactation ration (glucogenic or lipogenic) in a $3 \times 2$ factorial design. The experiment started with 60 primiparous and 107 multiparous cows. Cows were housed in a freestall with slatted floor and cubicles and milked twice daily ( $0500 \mathrm{~h}$ and $1630 \mathrm{~h}$ ). 


\subsubsection{Rations}

Ration composition was described previously (Van Knegsel, et al. 2014). Prepartum, dry cows received a dry cow ration and lactating cows received a lactation ration supporting $25 \mathrm{~kg}$ of milk. From $10 \mathrm{~d}$ prepartum, cows were fed 1 $\mathrm{kg} / \mathrm{d}$ of the experimental concentrate (glucogenic or lipogenic). Postpartum, all cows received $1 \mathrm{~kg}$ of experimental concentrate which was increased stepwise by $0.5 \mathrm{~kg} / \mathrm{d}$ until concentrate supply reached $8.5 \mathrm{~kg} / \mathrm{d}$ at d 17 postpartum. Experimental concentrates were provided by a computerized feeder located in the freestall. In addition, lactating cows received $1 \mathrm{~kg} / \mathrm{d}$ of standard lactation concentrate in the milking parlor. Forage did not differ between diets, was supplied ad libitum and consisted of grass silage, corn silage, wheat straw and a protein source (rapeseed meal or soybean meal) in a ratio of 39:25:25:11 (DM basis). Postpartum, forage consisted of grass silage, corn silage, straw, and a protein source (rapeseed meal or soybean meal) in a ratio 51:34:2:13 (DM basis).

\subsubsection{Management of Calves}

Immediately after birth, calves were removed from dam. When calves were born between 2200 until $0500 \mathrm{~h}(\mathrm{~N}=42)$ they were removed from the dam at 0500 h. Calves were weighed and within $24 \mathrm{~h}$ of life they received $4 \mathrm{~L}$ of colostrum in 2 portions from their mother. Secretion of the first milk was collected and weighed directly after calving, except when the cow calved between 2200 until $0500 \mathrm{~h}(\mathrm{~N}=$ 42). Colostrum obtained after parturition was agitated and colostrum samples (10 $\mathrm{ml})$ were stored at $-20^{\circ} \mathrm{C}$. At $24 \mathrm{~h}$ after birth, calves were fed with milk replacer (CP $22 \%$ and fat $17 \%)(2 \times / \mathrm{d}, 2 \mathrm{~L})$. After $2 \mathrm{~d}$, calves were moved to the calf-raising farm and were also fed milk replacer twice a day, until 60-d of life. After the first week of life, all calves were fed the same mixture of hay and grains (Agrifirm Feed, Apeldoorn, the Netherlands) based on requirements for preweaned Holstein calves. At $60-\mathrm{d}$ of life, calves were weaned from milk replacer. From $60-\mathrm{d}$ of life on, calves received a diet based on requirement for weaned Holstein calves. During first 2 weeks of life, calves were housed in individual hutches located approximately $60 \mathrm{~cm}$ apart. After 2 weeks, calves were kept in groups of 6 to 8 calves with straw-bedding. Body weight of female calves was recorded at birth and in week 2, 4, 6, 8, 10 and 12 after birth. Disease incidences were recorded. 


\subsubsection{Blood Sampling and Immunization}

Blood samples of female calves $(\mathrm{N}=63)$ were taken from the jugular vein immediately after birth and every Wednesday in week 1, 2, 4, 6, 7, 8, 10, 11, and 12 of life in Vacutainer tubes $(10 \mathrm{~mL}$, Becton Dickinson and Co., Franklin Lakes, $\mathrm{NJ})$ containing heparin to determine titers of total (IgT), IgG and IgM natural and specific antibody titers binding KLH or HuSA. Blood samples were centrifuged at $3,000 \times \mathrm{g}$ at $4^{\circ} \mathrm{C}$, for $15 \mathrm{~min}$ immediately after sample collection, and plasma was stored at $-20^{\circ} \mathrm{C}$ until analysis. Female calves were immunized twice with a combination of both KLH and HuSA. Solutions of KLH and HuSA were prepared by dissolving $2 \mathrm{mg}$ of KLH (H7017, Sigma Aldrich Co., St Louis, MO) and $0.2 \mathrm{mg}$ HuSA (A8763, Sigma Aldrich) in $2.5 \mathrm{~mL}$ PBS $(0.1 \mathrm{M}, \mathrm{pH}=7.2)$. Calves received a $2.0 \mathrm{~mL}$ i.m. injection in the neck at week 6 of life, and a second injection at week 10 of life.

\subsubsection{Analysis of Immunoglobulin Concentration in Colostrum}

Colostrum was not sampled during weekends. Total concentration of IgG and IgM in colostrum was determined by an indirect ELISA method using the Bovine IgG ELISA Quantitation Kit (Cat. No. E10-118, Bethyl Laboratories Inc., Montgomery, TX), and the Bovine IgM ELISA Quantitation Kit (Cat. No. E10101, Bethyl Laboratories). Kit performance was optimized for the stated protocol using affinity purified sheep anti-bovine IgG-heavy chain or IgM coating antibody, bovine reference serum and horseradish peroxidase (PO) conjugated sheep antibovine IgG-heavy chain or IgM detection antibody. Standard dilutions from 500$7,800 \mathrm{ng} / \mathrm{mL}$ of bovine $\mathrm{IgG}$ and $1,000-15,625 \mathrm{ng} / \mathrm{mL}$ of bovine IgM were used according to manufacturer's procedures.

\subsubsection{Analysis of Natural and Specific Antibodies in Colostrum and Plasma}

Natural antibody titers binding KLH and HuSA in plasma of female calves were measured by indirect ELISA as outlined by Van Knegsel et al. (2007). The same ELISA procedures were also used to measure NAb titers in colostrum and $\mathrm{SpAb}$ titers binding KLH and HuSA in plasma of female calves. Plates were coated with $4 \mu \mathrm{g} / \mathrm{mL}$ of KLH or $4 \mu \mathrm{g} / \mathrm{mL}$ of HuSA (100 $\mu \mathrm{L} /$ well). Natural antibody of the IgG isotype in colostrum were detected either using 1:40,000 diluted sheep polyclonal anti-bovine IgG-heavy chain conjugated to horseradish PO (Cat. No. E10-118P, Bethyl Laboratories), Natural antibody of the IgM isotype in colostrum was detected using 1:20,000 diluted rabbit polyclonal anti-bovine IgM-whole 
molecule conjugated to horseradish PO (Cat. No. A10-100P, Bethyl Laboratories). Serial dilutions for isotypes ( $\operatorname{IgG}$ and $\operatorname{IgM}$ ) in colostrum samples started at 1:10 (8 steps). Natural antibodies and SpAb isotypes IgM and IgG in plasma were detected either using 1:40,000 diluted sheep polyclonal anti-bovine IgG-heavy chain conjugated to horseradish PO (Cat. No. E10-118P, Bethyl Laboratories), or 1:20,000 diluted rabbit polyclonal anti-bovine IgM-whole molecule conjugated to horseradish PO (Cat. No. A10-100P, Bethyl Laboratories) or 1:20,000 diluted rabbit anti-bovine IgG heavy and light chain conjugated to PO (Cat. No. A10102P, Bethyl Laboratories) for IgT. Serial dilutions for isotypes (IgG, IgM, and IgT) in plasma samples started at 1:40 (4 steps). Titers were expressed as $\log 2$ values of the dilutions that gave an extinction closest to 50\% of Emax, where Emax represents the highest mean extinction of a standard positive (pooled) serum present on every microtiter plate (Ploegaert et al., 2007). Preliminary analysis showed the highest response of antigen $\mathrm{SpAb}$ after primary and secondary immunizations in weeks 10 and 11 of life, respectively. Therefore, response to primary antigen challenges was defined by subtracting the $\mathrm{SpAb}$ titers for isotype IgG, IgM and IgT binding KLH and HuSA at week 10 after primary immunization with titers at week 6 . Response to secondary antigen challenges was defined by subtracting the $\mathrm{SpAb}$ titers for isotype IgG, IgM and IgT binding KLH and HuSA at week 11 after secondary immunization with titers at week 10 .

\subsubsection{Statistical Analysis}

Three pairs of twins ( 4 calves from cows with a 60-d dry period and 2 calves from cows with a 0 -d dry period) and 3 stillborn calves ( 2 calves from cows with a 0 -d dry period and 1 calf from cow with a 60-d dry period) were excluded from the analysis. Three female calves, 1 calf from a cow with a 30-d dry period and 2 calves from cows with a 0-d dry period died in the rearing unit before week 6 and were removed from analysis. The ANOVA PROC MIXED procedure (SAS version 9.2; SAS Institute Inc., Cary, NC, Littell et al., 1996) was used to analyze colostrum immunoglobulin content, pregnancy length, birth weight, growth, and plasma antibody titers. Preliminary analysis showed no effect of dietary treatments on colostrum, plasma and growth variables, therefore ration was excluded from the analysis. Colostrum immunoglobulin content, NAb titer binding KLH or HuSA in colostrum, calf growth and the response after primary antibody challenge at 6 weeks and secondary antibody challenge at week 10 were analyzed with dry period length $(0,30$ or 60 days), parity $(2,3$ or $>3)$, and their interaction included as fixed 
effect (model 1). Preliminary analysis showed there was no difference between concentrations of $\operatorname{IgG}$ and $\operatorname{IgM}$ in colostrum collected directly after calving and concentrations of IgG and IgM in colostrum from cows which calved during 2200 - $0500 \mathrm{~h}(\mathrm{~N}=42)$. Thus, both colostrum samples from cows which calved during night and cows which calved during the day were included in the analysis. Pregnancy length and birth weight for all calves were analyzed with dry period length $(0,30$ or $60 \mathrm{~d})$, parity $(2,3$ or $>3)$, sex and interactions included as fixed effects (model 2). Natural antibody titers (week 0 until 6) and specific antibody titers after primary (week 6 until 10) and secondary immunization (week 10 until $12)$ in plasma were analyzed with dry period length $(0,30$ or $60 \mathrm{~d})$, parity $(2,3$ or $>$ 3 ), week (1 - 12) and interactions included as fixed effects (model 3). In model 3 , calf was considered as the repeated subject. A first-order auto-regressive structure [AR (1)] was the best fit and was used to account for within-calf variation. For comparison of dry period length effects $P$-values are presented after a Bonferroni adjustment. Model assumption regarding normality of residuals was evaluated by examining whether skewness and kurtosis were close to 0 . Values are presented as LSMEANS with their pooled SEM, unless otherwise stated. Pearson correlation coefficient (PROC CORR in SAS) were used to test the correlation between NAb titers (IgG and IgM) binding KLH or HuSA in colostrum and NAb titers (IgG and $\mathrm{IgM}$ ) binding KLH or HuSA in plasma of calves.

\subsection{Results}

\subsubsection{Colostrum}

Cows with a 60-d dry period had greater colostrum production at first milking after calving compared with cows with a 0 - or 30-d dry period (7.7 vs. 5.3 vs. $5.1 \pm 0.6 \mathrm{~kg}$ for cows with 60 - vs. 30 - vs. 0 -d dry; respectively, $P<0.01$ ). Cows with a 0 -d dry period had lower $\operatorname{IgG}$ and $\operatorname{IgM}$ concentration in colostrum (Figure 5.1a) compared with cows with a $30-\mathrm{d}$ or $60-\mathrm{d}$ dry period. There were no differences in IgG or IgM concentration in colostrum between cows with a 30-d and cows with a $60-\mathrm{d}$ dry period. Concentration of $\mathrm{IgG}$ in colostrum increased with parity ( 20.9 vs. 27.0 vs. $30.8 \pm 2.2 \mathrm{mg} / \mathrm{mL}$ for parity 2 vs. 3 vs. $>3$, respectively; $P$ $=0.01$ ). Titers for IgG and IgM binding KLH and HuSA in colostrum were lower for cows with a 0 -d dry period compared with cows with a 30-d or 60-d dry period (Figure 5.1b). Natural antibody titers in colostrum increased with parity, except natural IgM binding HuSA. 

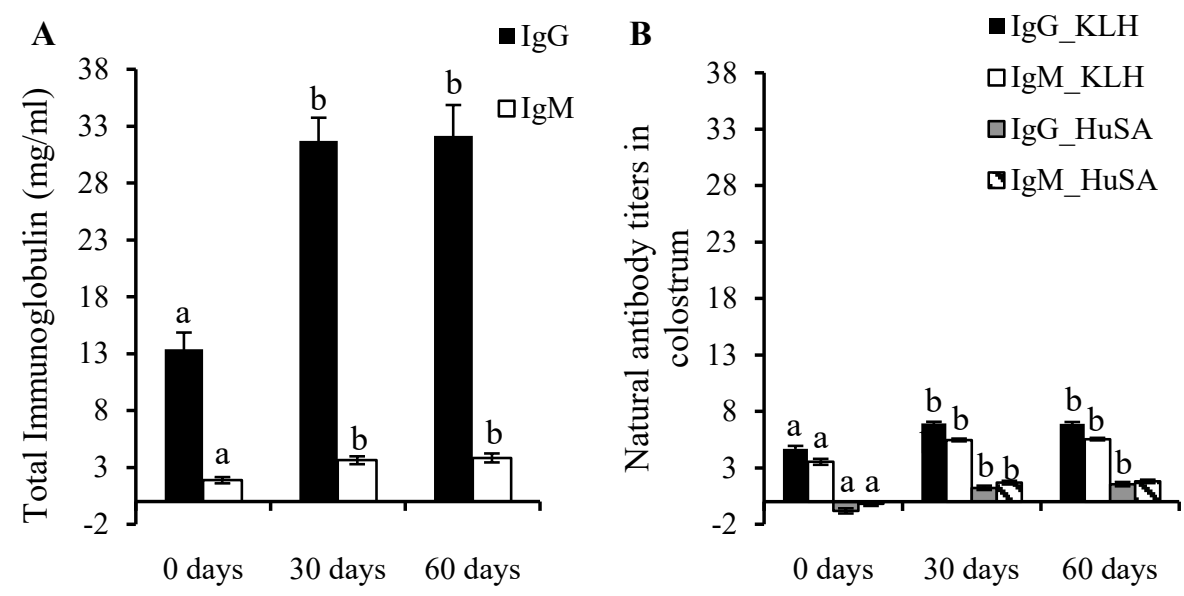

Figure 5.1 Concentration of $\operatorname{IgG}$ and $\operatorname{IgM}$ (A.) and natural antibodies (NAb) for isotype IgG and IgM titers binding keyhole limpet hemocyanin (KLH) and human serum albumin (HuSA) (B.) in colostrum from cows with 3 different dry period lengths $(0,30$ or $60 \mathrm{~d})$. Values are means $( \pm$ SEM) per dry period length. a, b, c values between dry period length with different superscripts differ $(P<0.05)$.

\subsubsection{Birth Weight and Growth of Calves}

Calves from cows with a 0 -d dry period were born $3 \mathrm{~d}$ earlier $(P=0.01)$, and had a lower birth weight $(P=0.04)$ compared with calves from cows with a 30-d or 60-d dry period (Table 5.1). Omitting the dry period resulted in lower birth weight of the male calves $(43.7$ vs. 46.5 vs. $46.2 \pm 0.8 \mathrm{~kg}$ for 0 -d vs. 30 -d vs. 60 -d dry period, respectively, $P=0.02$ ) but did not affect birth weight of the female calves $(42.3 \pm 0.8 \mathrm{~kg})$. Cows with a 0 -d dry period had shorter pregnancy length and lower birth weight compared with cows with a $30-\mathrm{d}$ or $60-\mathrm{d}$ dry period. Pregnancy length showed positive relation with birth weight of calves from cows with 0 -d dry period. Body weight of the female calves before first immunization at week 6 was not different between dry period lengths ( 56.9 vs. 60.6 vs. $58.9 \pm 0.2 \mathrm{~kg}$, for 0 -d vs. 30 -d vs. 60-d dry period, respectively, $P=0.12$ ). Growth of female calves from day 0 until week 12 of life and live weight of female calves at week 12 (data not shown) were not different between dry period lengths of the cows $(P=0.19$ and $P$ $=0.18$, respectively). Disease incidence of calves did not differ among dry period lengths. 
Table 5.1 Birth weight, pregnancy length and growth of calves during the first 12 weeks of life from cows with different dry period lengths $(0,30$, or $60 \mathrm{~d})(\mathrm{LSM} \pm \mathrm{SEM})$.

\begin{tabular}{|c|c|c|c|c|c|c|c|c|}
\hline \multirow{2}{*}{ Performance } & \multicolumn{3}{|c|}{ Dry period lengths $(\mathrm{d})^{3}$} & \multirow{2}{*}{ SEM } & \multicolumn{4}{|c|}{$\mathrm{P}$-values ${ }^{5}$} \\
\hline & 0 & 30 & 60 & & $\mathrm{D}$ & $\mathrm{P}$ & $\mathrm{S}^{4}$ & $\mathrm{D} \times \mathrm{P}$ \\
\hline Calves (no.) & 54 & 54 & 51 & & & & & \\
\hline Birth weight $(\mathrm{kg})$ all $^{1}$ & $42.9^{\mathrm{a}}$ & $44.7^{\mathrm{b}}$ & $44.4^{\mathrm{ab}}$ & 0.55 & 0.04 & 0.27 & $<0.01$ & 0.23 \\
\hline Pregnancy length (days) & $278^{\mathrm{a}}$ & $280^{\mathrm{b}}$ & $281^{\mathrm{b}}$ & 0.63 & 0.01 & 0.12 & 0.25 & 0.82 \\
\hline Growth $(\mathrm{kg} / \text { day })^{2}$ & 0.6 & 0.7 & 0.7 & 0.02 & 0.19 & 0.04 & $\mathrm{~nm}$ & 0.90 \\
\hline
\end{tabular}

\subsubsection{Natural Antibody Titers in Plasma of Calves}

Calves from cows with a 0 -d dry period had lower natural IgG, IgM and IgT in plasma compared with calves from cows with 60-d dry period (Table 5.2), except for IgG binding HuSA. Natural antibody titers for calves from cows with a 0 -d dry period were specifically lower immediately after calving (week 0 ), and in week 1 and 2 (Figure 5.2). Natural IgT binding KLH and HuSA in plasma increased with parity ( 2.2 vs. 2.5 vs. $3.0 \pm 0.2$ and 1.4 vs. 1.9 vs. $1.9 \pm 0.1$ for parity 2 vs. 3 vs. $>3$ for IgT binding KLH and HuSA, respectively). Natural IgT binding KLH and HuSA in plasma of calves were affected by dry period $\times$ parity interaction $(P<0.01$ and $P=0.02$, respectively). Titers of natural $\operatorname{IgG}$ and $\operatorname{IgM}$ binding KLH and HuSA in colostrum correlated positively with titers of natural IgG and IgM binding KLH and HuSA in plasma of calves at calving $(r=0.73, P<$ 0.01 and $r=0.70, P<0.01$ for IgG and IgM binding KLH, respectively, and $r=$ $0.41, P<0.01$ and $r=0.65, P<0.01$ for $\operatorname{IgG}$ and IgM binding HuSA, respectively). There were no correlations between NAb titers present in colostrum and NAb titers in plasma of calves after 2 weeks.

\subsubsection{Primary and Secondary Antibody Responses to KLH and HuSA}

Primary and secondary SpAb titers for all isotypes binding KLH and HuSA in plasma of calves did not differ between dry period lengths (Table 5.3). All SpAb titers (IgG, IgM, and IgT) binding KLH or HuSA in plasma of calves increased following primary and secondary immunization (Figure 5.2) except for $\operatorname{IgM}$ binding KLH or HuSA after the secondary immunization. Specific antibody titers for isotype $\mathrm{IgG}$ and $\mathrm{IgT}$ binding HuSA in calves increased with parity of the cows. 
After primary immunization, calves from younger cows (parity 2) had lower specific IgG titers binding HuSA ( 2.0 vs. 3.0 vs. $2.8 \pm 0.3$ for parity 2 vs. 3 vs. $>3$, respectively; $P=0.05$ ) and lower IgT titers binding HuSA ( 2.8 vs. 4.4 vs. $4.0 \pm 0.3$ for parity 2 vs. 3 vs. $>3$, respectively; $P<0.01$ ) compared with calves from older cows. After secondary immunization, calves born from younger cows had lower specific IgG titers binding HuSA ( 3.7 vs. 5.2 vs. $5.0 \pm 0.4$ for parity 2 vs. 3 vs. $>3$, respectively; $P=0.04$ ) and IgT titers binding HuSA ( 4.9 vs. 7.0 vs. $6.4 \pm 0.5$ for parity 2 vs. 3 vs. $>3$, respectively; $P=0.01$ ) compared with calves from older cows. After secondary immunization, there was a dry period length $\times$ week interaction for titers of $\operatorname{IgG}(P<0.01)$ and $\operatorname{IgT}$ binding $\mathrm{KLH}(P=0.02)$. Calves born from cows with a 0-d dry period had higher plasma titers of specific IgG binding KLH and IgT binding KLH compared with calves born from cows with a 30 - or a $60-\mathrm{d}$ dry period.

After primary antigen challenge, the IgG binding KLH response tended to be higher for the calves from cows with a 0-d dry period compared with calves from cows with a 30-d or 60-d dry period (Table 5.4). After primary antigen challenge, IgT binding KLH response was higher for the calves from cows with a 0 -d dry period compared with calves from cows with a 30-d or 60-d dry period. Also secondary IgG and $\operatorname{IgT}$ responses binding KLH were enhanced in calves born from mothers with a $0-d$ dry period, compared with a $30-d$ or $60-d$ dry period. The responses of $\mathrm{SpAb}$ in plasma of calves after both primary and secondary immunization between a $30-\mathrm{d}$ and a $60-\mathrm{d}$ dry period were not different. 

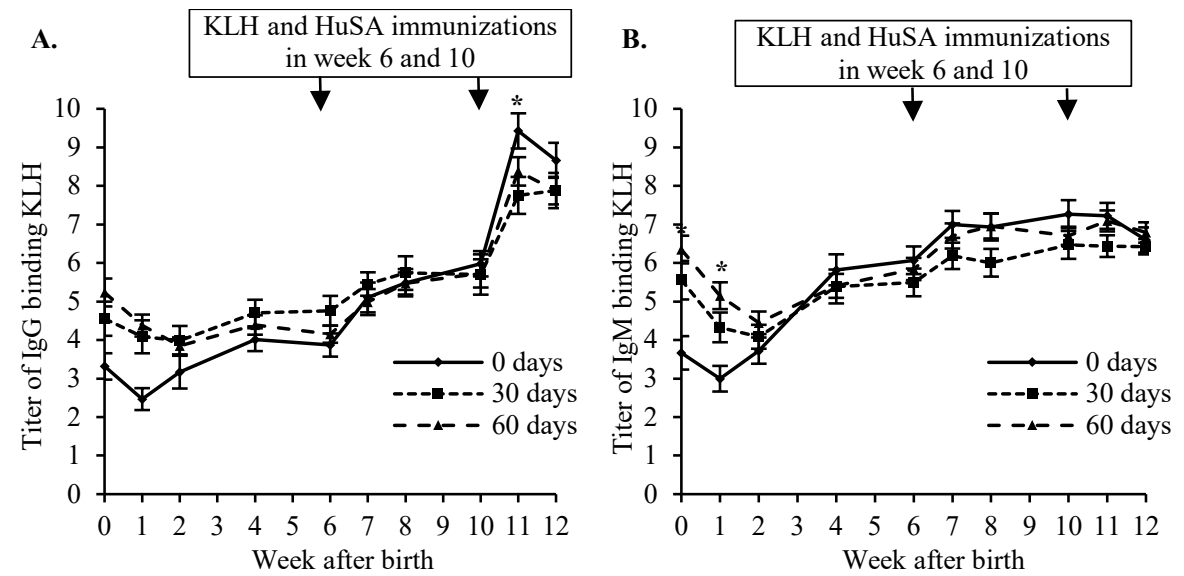

C.

D.
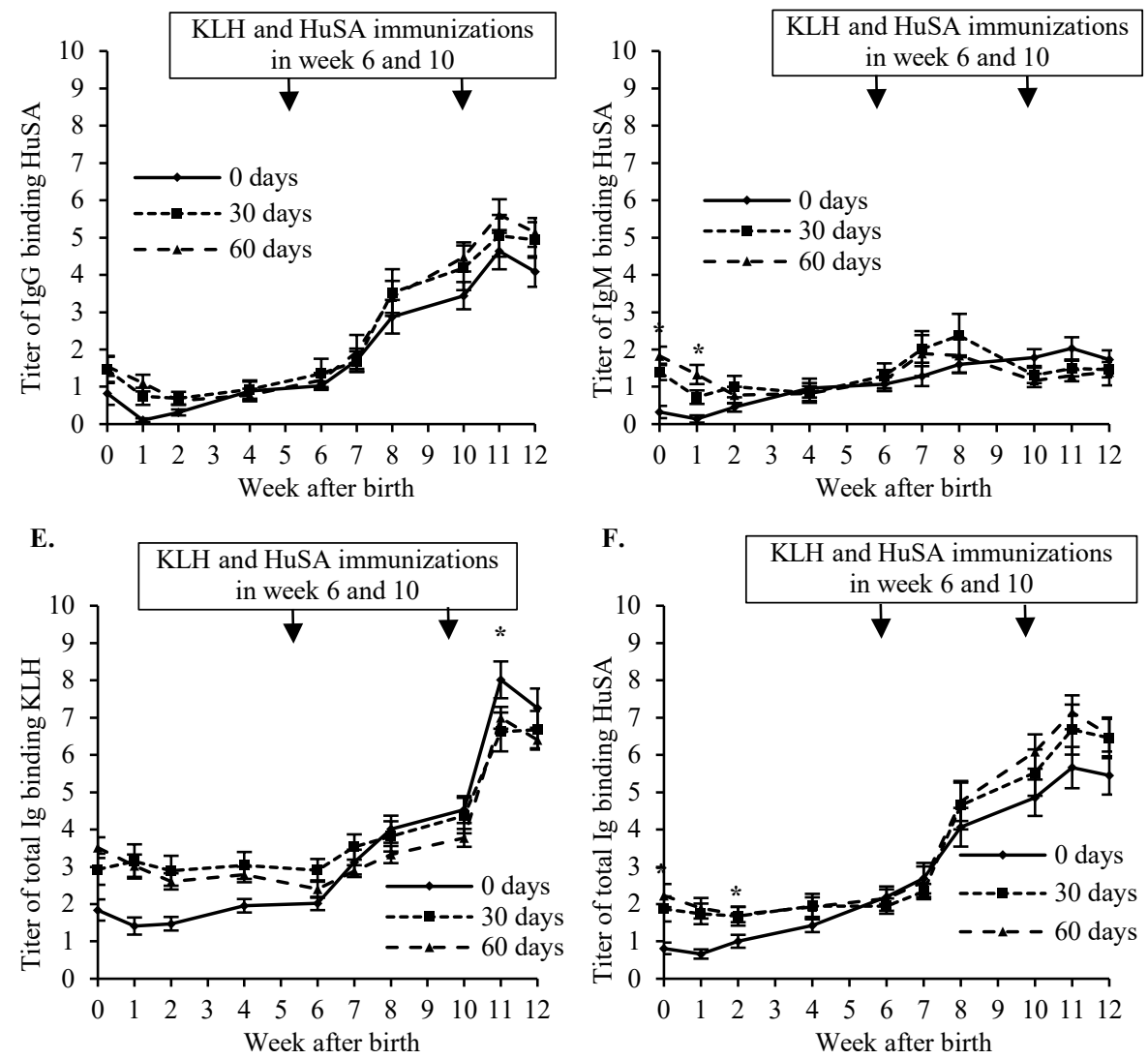

Figure 5.2 Natural antibodies (week 0 until week 6) and specific antibodies (after primary and secondary immunization) for IgG, IgM, and total immunoglobulin (IgT) titers binding keyhole limpet hemocyanin (KLH) (A, C, and E) and human serum albumin (HuSA) (B, D, and F) in plasma of female calves from dairy cows with 0,30 or 60 days dry period. Values represent means $( \pm$ SEM) per dry period length (DPL) per week (W). 

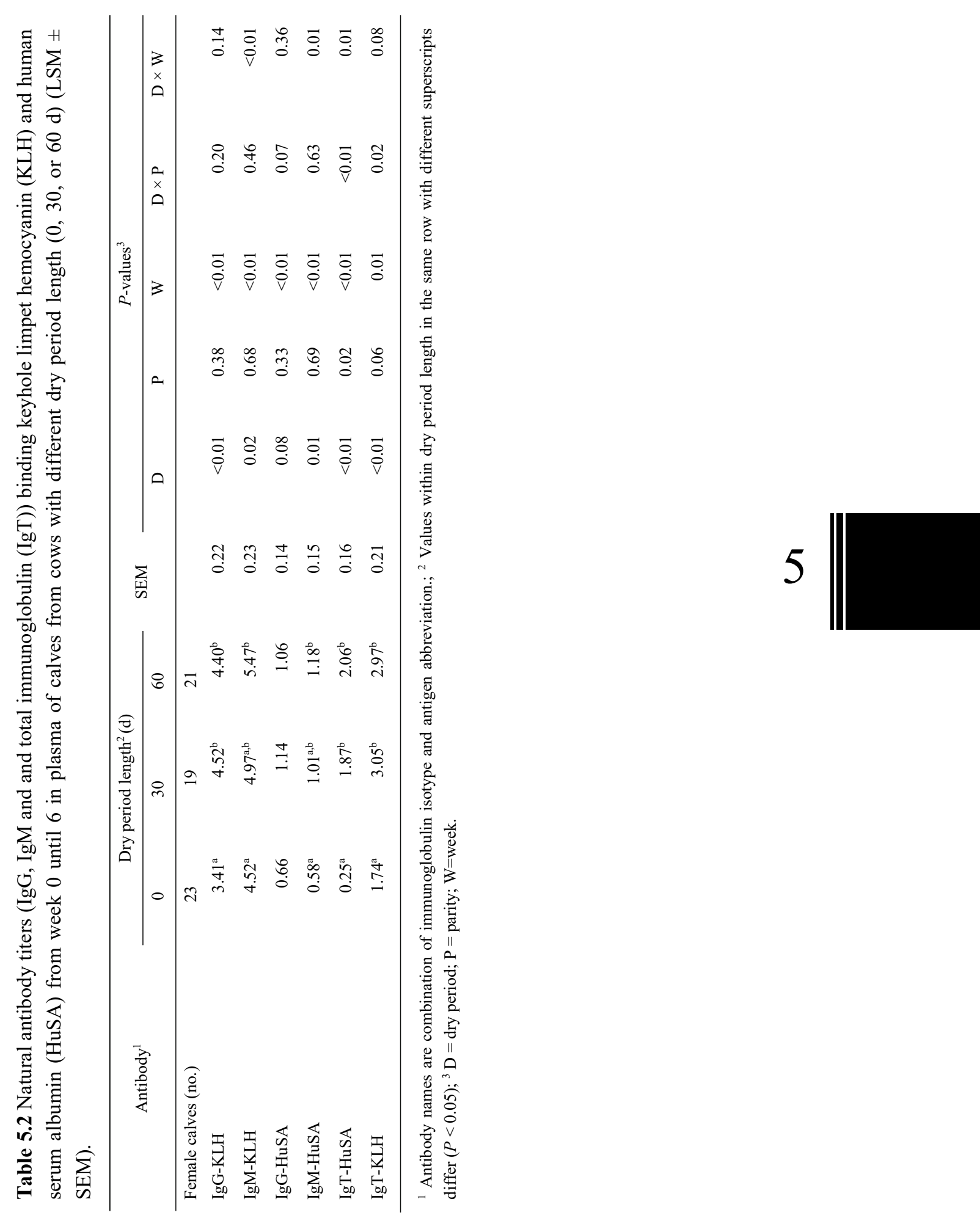


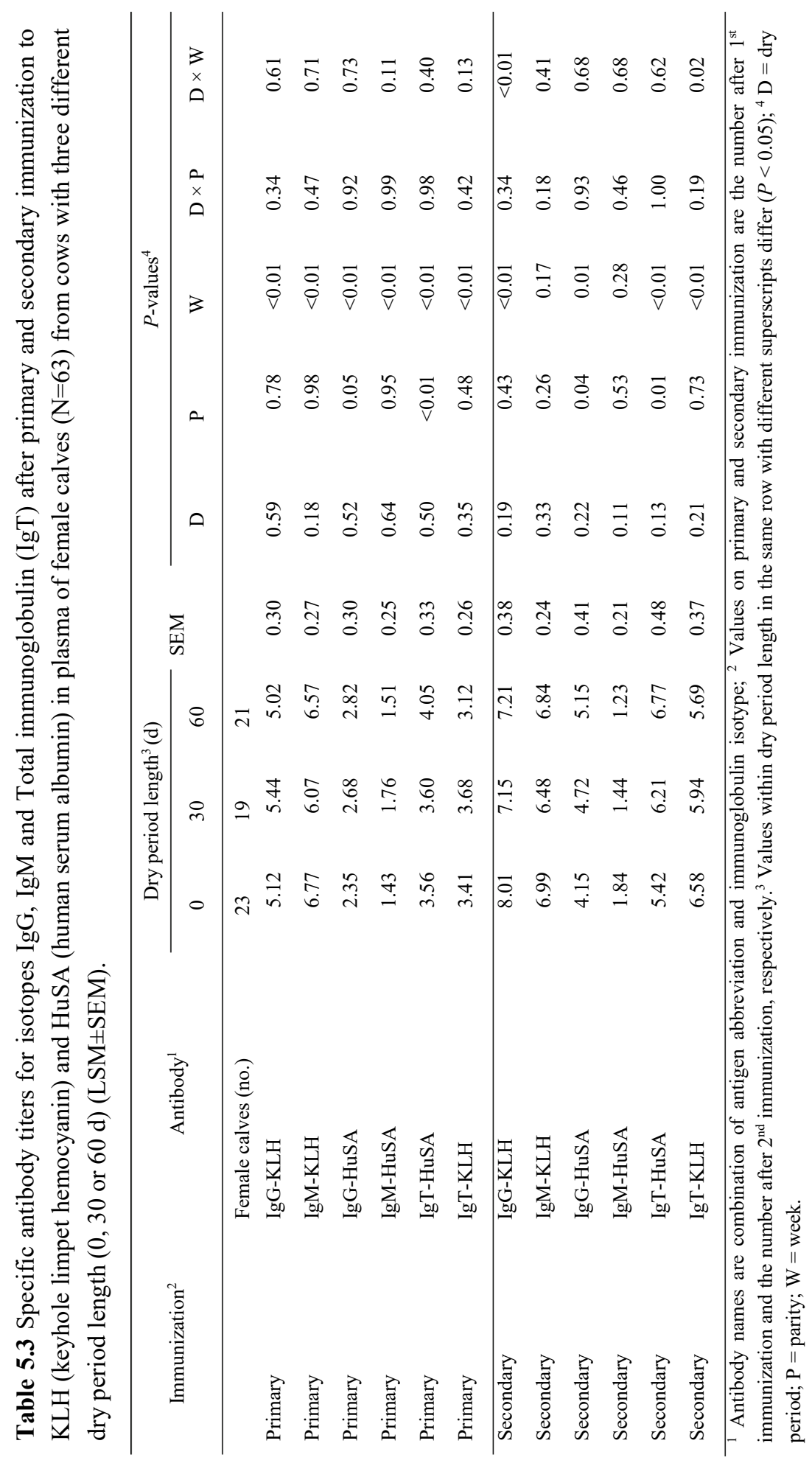



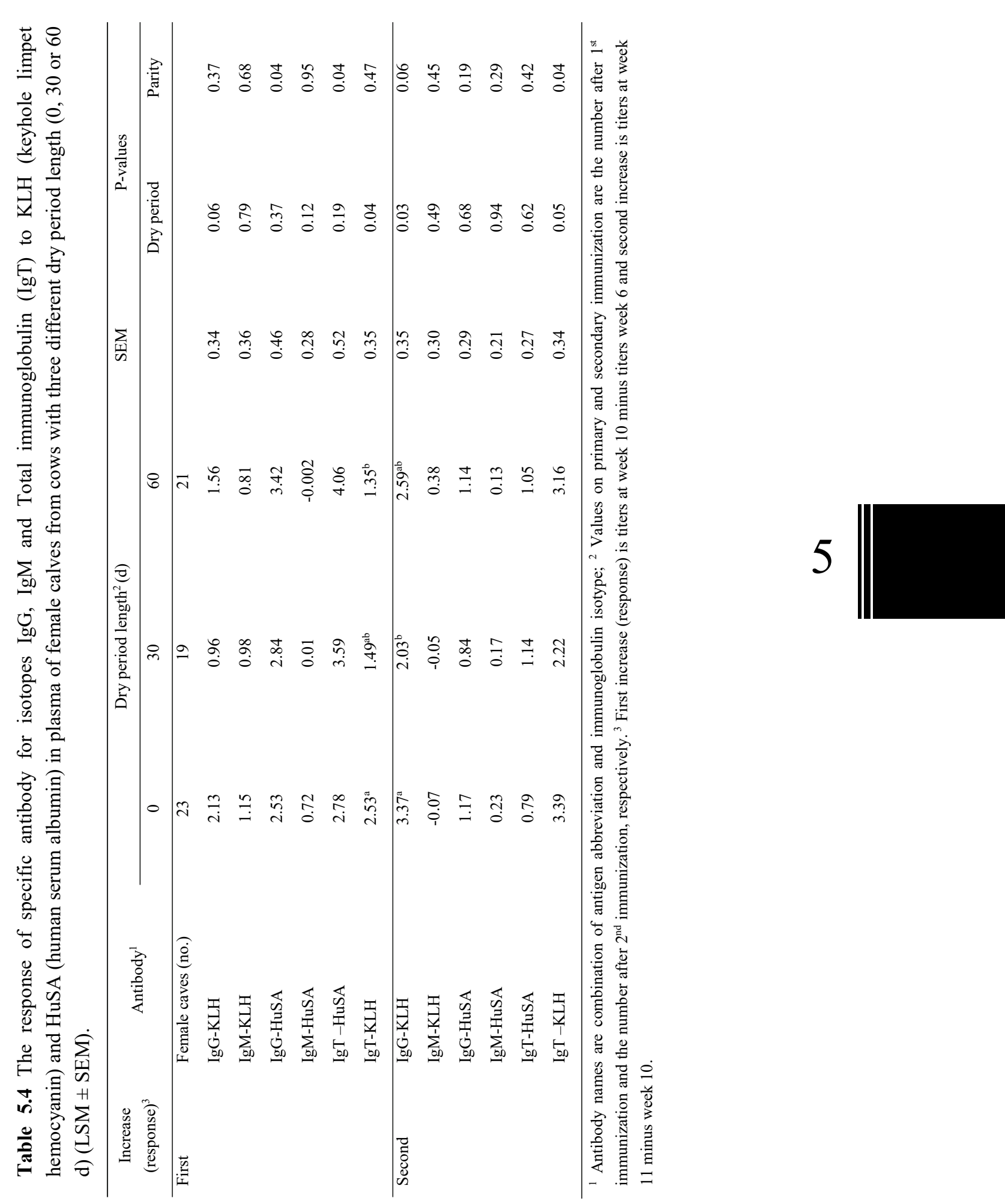


\subsection{Discussion}

The present study shows that a 0-d dry period for dairy cows resulted in lower NAb titers binding KLH or HuSA in calves in the first 2 weeks of life, compared with calves from cows with a 30-d or 60-d dry period. Specific antibody titers binding KLH and HuSA after primary immunization in week 6 or secondary immunization in week 10 of life did not differ between calves born from mothers with different dry period lengths. After secondary immunization, however, calves from cows with a 0-d dry period showed higher IgG and IgT binding KLH titers compared with calves from cows with a 30-d or 60-d dry period. This suggests that specific humoral immune competence of calves from cows with a 0 -d dry period length was not negatively affected.

Natural antibodies detected in plasma of calves immediately after birth are likely derived from colostrum since calves are born without antibodies in blood (Srinivasan et al., 1999). In our study, NAb titers in colostrum were positively correlated with $\mathrm{NAb}$ titers in plasma of calves during the first 2 weeks of life. In addition, natural IgG and IgM binding to KLH and HuSA in plasma of calves was correlated positively with natural $\operatorname{IgG}$ and IgM binding to KLH and HuSA in colostrum. In the current study, concentrations of IgG and IgM and natural IgG and IgM binding KLH or HuSA in colostrum were reduced when cows had a 0 -d dry period compared with cows with a 30-d or 60-d dry period. This study concurs with results of earlier studies (Annen et al., 2004, Klusmeyer et al., 2009, Rastani et al., 2005, Verweij et al., 2014), which detected a reduction in IgG concentration in colostrum after omission of the dry period compared with a conventional dry period. Concentration of $\operatorname{IgG}$ was lower in present study compared with earlier studies (Annen et al., 2004, Klusmeyer et al., 2009, Rastani et al., 2005, Watters et al., 2008). In these earlier studies, single radial immunodiffusion assays (RID) was used to assess antibody level in colostrum (Annen et al., 2004, Klusmeyer et al., 2009, Rastani et al., 2005, Watters et al., 2008). In the present study, immunoglobulin concentration in colostrum was assessed by an ELISA and results were comparable with previous studies using ELISA [for IgG concentrations; $32.62 \mathrm{mg} / \mathrm{mL}$ (Horn et al., 2010) or $41.5 \mathrm{mg} / \mathrm{mL}$ (Verweij et al., 2014)].

In the present study, cows with a $0-d$ dry period, but not cows with a 30-d dry period, had lower colostrum production and lower colostrum immunoglobulin content at first milking compared with cows with a 60-d dry period, which is in line with previous studies (Rastani et al., 2005, Klusmeyer et al., 2009, Verweij et al., 2014). Moreover, it seems that although IgG mass produced at day of calving was 
lower for cows with a 0-d dry period, the total IgG mass produced during colostrogenesis is not different from cows with a 60-d dry period (Baumrucker et al., 2014), which was explained by additional IgG production during the prepartum period for cows with a 0-d dry period, compared with cows with a 60-d dry period. This implies that colostrum production for cows with a 0-d dry period is not compromised, but secretion is distributed over more days, resulting in a lower colostrum secretion at the day of calving (Baumrucker et al., 2014).

Variation in immunoglobulin content in colostrum and milk has been explained by stage of lactation of the cows, milking processes or milking frequency (Stelwagen et al., 2009). In addition, the current study shows variation between parities. Young cows had lower NAb titers binding HuSA in colostrum than older cows, which is consistent with previous studies (Kruse, 1970, Muller and Ellinger, 1981, Pritchett et al., 1991). Moreover, in the current study natural IgT binding KLH and HuSA were lower in plasma of calves born from young cows than in calves from older cows. The same results were found for SpAb, the titers of IgT binding HuSA and specific IgG binding HuSA were lower after primary and secondary immunization in plasma of calves from young cows than in calves from older cows. Our study is in line with Conneely et al. (2013) which suggested that older cows are more likely to be exposed to a greater number of antigens in their life (Larson et al., 1980), resulting in more transfer of the antibodies from blood to colostrum and greater antibody titers in plasma of calves. In the present study all calves received $4 \mathrm{~L}$ colostrum; hence, intake of NAb by calves may directly reflect the concentration of (natural) IgG, and IgM present in the consumed colostrum. The current results show that albeit calves from cows with a 0-d dry period had lower titers of NAb binding KLH or HuSA in the first 2 weeks of life, calves from cows with a 0-d dry period eventually had similar titers of SpAb binding KLH and HuSA both after primary and secondary immunization. This suggests that calves with lower titers of NAb in the first 2 weeks of life mounted a higher SpAb response after primary and secondary immunization than calves with higher titers of NAb in the first 2 weeks of life. The titers of NAb may facilitate subsequent specific antibody responses (Lammers et al., 2004). The low level of NAb and high subsequent antibody response in our study were in line with earlier studies which reported that low NAb titers are related to high levels of SpAb following vaccination or immunization (Sinyakov and Avtalion, 2009), and high NAb titers that are related to low specific antibody responses (Parmentier et al., 2008). As expected, an IgG response was found after secondary challenge. Secondary IgG 
response of calves born from cows with a 0-d dry period was enhanced after secondary immunization.

Higher NAb titers in plasma have been related with higher survival rates and less disease incidence in birds (Star et al., 2007, Sun et al., 2011), fish (Kacharnakova et al., 2006, Sinyakov et al., 2002), reptiles (Ujvari and Madsen, 2011) and mammals (Ochsenbein et al., 1999, Thornton et al., 1994). It remains to be studied whether temporarily lowered NAb titers as found in calves from cows with no dry period in the present study may have consequences for disease incidence and immune competence of the calves later on. Calves from cows with the 0-d dry period received 47 percent less immunoglobulin via colostrum, whereas the calves from cows with a 30 - or 60-d dry period received 25 percent more immunoglobulin than recommended [100 g of IgG by NRC (2001)]. Calves from cows with a 0 -d dry period received less NAb in the colostrum but seem to be able to come to the same level of NAb during the first 6 weeks of life; thus, apparently their intrinsic capacity to produce NAb themselves may be greater than calves from cows with a $30-\mathrm{d}$ or $60-\mathrm{d}$ dry period. The data even indicated that calves with low NAb titers mount higher $\mathrm{SpAb}$ responses.

In the current study, omission of the dry period was also accompanied by a shorter pregnancy length and lower birth weight of the calves compared with calves from cows with a $30-\mathrm{d}$ or $60-\mathrm{d}$ dry period. In agreement with previous studies, in the current study no difference between the 30-d and the 60-d dry period was noted with respect to pregnancy length (Santschi et al., 2011b) and birth weight of calves (Pezeshki et al., 2007, Rastani et al., 2005). In the present study, no differences in growth and disease incidence of the calves were observed during the observation period of 12 weeks of life. The hygiene conditions in our study can be expected to be high. Calves from study were all raised at a specific calf raising farm. This farm is located approximately $15 \mathrm{~km}$ from the main research farm and raises only dairy calves for this specific research farm. The physical environmental conditions, such as housing conditions and the level of hygiene, will influence mortality and morbidity rates, effectiveness of good nutrition, and management programs (Davis and Drackley, 1998). In the present study, no intentional infection was performed; therefore no information on disease resistance was obtained. Apparently, in the current study, omitting the dry period did result in lower immunoglobulin contents and lower NAb titers in colostrum and as a consequence low NAb titers during the first 2 weeks of life in plasma of the calves, without negative consequences for growth and disease incidence during the first 12 weeks 
of life. It can be hypothesized that calves that do not have the ability to recover their NAb levels, have more health problems and compromised performance in later life. During the limited observation period of 12 weeks, this was not the case. More long-term studies are needed that monitor health of calves from cows that received different dry period lengths under conditions with for example a lower hygiene status.

\subsection{Conclusions}

Omitting the dry period of dairy cows resulted in lower plasma NAb titers in calves in the first 2 weeks of life compared with calves from cows with a dry period of 30-d or 60-d. Lower NAb in plasma of calves was likely caused by lower immunoglobulin content in colostrum compared with calves from cows with a dry period of 30-d or 60-d. Lower NAb in plasma did not affect calf growth and $\mathrm{SpAb}$ titers. Calves from cows with a 0 -d dry period showed a greater capacity to produce NAb themselves in the first 6 weeks and showed an increased capacity to mount specific antibody responses as exemplified during the secondary response. This suggested that calves from cows with a 0-d dry period had earlier immune maturation and had faster response to challenges than other calves.

\subsection{Acknowledgements}

The authors thank the Dutch Dairy Board (PZ, Zoetermeer, and the Netherlands), Product Board Animal Feed (PDV; Zoetermeer, the Netherlands) and CRV (Arnhem, The Netherlands) for financing the experiment. The authors also thank the Directorate General of Higher Education, Ministry of National Education, Jakarta, Indonesia, for scholarship of Novi Mayasari. The authors thank Joop Arts and the staff of Dairy Campus (Lelystad, the Netherlands) for technical support during analysis and experiment. 


\section{References}

Andersen, J. B., T. G. Madsen, T. Larsen, K. L. Ingvartsen, and M. O. Nielsen. 2005. The effects of dry period versus continuous lactation on metabolic status and performance in periparturient cows. J. Dairy Sci. 88:3530-3541.

Annen, E. L., R. J. Collier, M. A. McGuire, J. L. Vicini, J. M. Ballam, and M. J. Lormore. 2004. Effect of modified dry period lengths and bovine somatotropin on yield and composition of milk from dairy cows. J. Dairy Sci. 87:3746-3761.

Avrameas, S. 1991. Natural autoantibodies: From 'horror autotoxicus' to 'gnothi seauton'. Immunol. Today 12:154-159.

Baumgarth, N., J. W. Tung, and L. A. Herzenberg. 2005. Inherent specificities in natural antibodies: A key to immune defense against pathogen invasion. Springer Semin. Immunopathol. 26:347-362.

Baumrucker, C. R., R. S. Zbinden, H. A. van Dorland, G. J. Remmelink, B. Kemp, A. T. M. van Knegsel, and R. M. Bruckmaier. 2014. Continuous milking of dairy cows disrupts timing of peak $\operatorname{IgG}$ concentration appearance in mammary secretions. J. Dairy Res. 1-7.

Casali, P. and A. L. Notkins. 1989. CD5+ B lymphocytes, polyreactive antibodies and the human B-cell repertoire. Immunol. Today. 10:364-368.

Conneely, M., D. Berry, R. Sayers, J. Murphy, I. Lorenz, M. Doherty, and E. Kennedy. 2013. Factors associated with the concentration of immunoglobulin $G$ in the colostrum of dairy cows. Animal. 1-9.

Davis, C. L. and Drackley, J. K. 1998. The development, nutrition, and management of the young calf. 1st ed. Iowa State Univ. Press. Ames, Iowa.

Horn, M. J., M. L. Van Emon, P. J. Gunn, S. D. Eicher, R. P. Lemenager, J. Burgess, N. Pyatt, and S. L. Lake. 2010. Effects of maternal natural (RRR $\alpha$-tocopherol acetate) or synthetic (all-rac $\alpha$-tocopherol acetate) vitamin E supplementation on suckling calf performance, colostrum immunoglobulin $\mathrm{G}$, and immune function. J.Anim. Sci. 88:3128-3135.

Kacharnakova, N. M., G. Irnazarow, H. K. Parmentier, H. F. J. Savelkoul, A. Pilarczyk, and G. F. Wiegertjes. 2006. Genetic differences in natural antibody levels in common carp (Cyprinus carpio L.). Fish Shellfish Immunol. 21:404-413.

Klusmeyer, T. H., A. C. Fitzgerald, A. C. Fabellar, J. M. Ballam, R. A. Cady, and J. L. Vicini. 2009. Effect of recombinant bovine somatotropin and a shortened or no dry period on the performance of lactating dairy cows. J. Dairy Sci. 92:5503-5511.

Kruse, V. 1970. Yield of colostrum and immunoglobulin in cattle at the first milking after parturition. Anim. Prod. 12:619-626.

Lammers, A., M. E. V. Klomp, M. G. B. Nieuwland, H. F. J. Savelkoul, and H. K. Parmentier. 2004. Adoptive transfer of natural antibodies to non-immunized chickens affects subsequent antigen-specific humoral and cellular immune responses. Develop. Comp. Immunol. 28:51-60.

Larson, B. L., H. L. Heary, and J. E. Devery. 1980. Immunoglobulin production and transport by the mammary gland. J. Dairy Sci. 63:665-671.

Littell, R. C., G. A. Milliken, W. W. Stroup, and R. D. Wolfinger. 1996. SAS system for mixed models. SAS Institute Inc., Cary, NC.

Matter, M. S. and A. F. Ochsenbein. 2008. Natural antibodies target virus-antibody complexes to organized lymphoid tissue. Autoimmun. Rev. 7:480-486. 
Muller, L. and D. Ellinger. 1981. Colostral immunoglobulin concentrations among breeds of dairy cattle. J. Dairy Sci. 64:1727-1730.

National Research Council. 2001. Nutrient Requirements of Dairy Cattle: 7th rev. ed. Natl. Acad. Press, Washington, DC.

Ochsenbein, A. F., T. Fehr, C. Lutz, M. Suter, F. Brombacher, H. Hengartner, and R. M. Zinkernagel. 1999. Control of early viral and bacterial distribution and disease by natural antibodies. Science. 286:2156-2159.

Oliveira, R. A., C. D. Narciso, R. S. Bisinotto, M. C. Perdomo, M. A. Ballou, M. Dreher, and J. E. P. Santos. 2010. Effects of feeding polyphenols from pomegranate extract on health, growth, nutrient digestion, and immunocompetence of calves. J. Dairy Sci. 93:4280-4291.

Parmentier, H. K., A. Lammers, J. J. Hoekman, G. D. V. Reilingh, I. T. A. Zaanen, and H. F. J. Savelkoul. 2004. Different levels of natural antibodies in chickens divergently selected for specific antibody responses. Dev. Comp. Immunol. 28:39-49.

Parmentier, H.K., G. De Vries Reilingh, and A. Lammers. 2008. Decreased specific antibody responses to alpha-Gal-conjugated antigen in animals with pre-exisitng high levels of natural antibodies binding Alpha-Gal residues. Poultry Sci. 87: 918926.

Pezeshki, A., J. Mehrzad, G. R. Ghorbani, H. R. Rahmani, R. J. Collier, and C. Burvenich. 2007. Effects of short dry periods on performance and metabolic status in holstein dairy cows. J. Dairy Sci. 90:5531-5541.

Ploegaert, T. C. W., E. Tijhaar, T. J. G. M. Lam, A. Taverne-Thiele, J. J. van der Poel, J. A. M. van Arendonk, H. F. J. Savelkoul, and H. K. Parmentier. 2011. Natural antibodies in bovine milk and blood plasma: Variability among cows, repeatability within cows, and relation between milk and plasma titers. Vet. Immun. and Immunopath. 144:88-94.

Ploegaert, T. C. W., G. De Vries Reilingh, M. G. B. Nieuwland, A. Lammers, H. F. J. Savelkoul, and H. K. Parmentier. 2007. Intratracheally administered pathogenassociated molecular patterns affect antibody responses of poultry. Poultry Sci. 1667-1676.

Pritchett, L. C., C. C. Gay, T. E. Besser, and D. D. Hancock. 1991. Management and production factors influencing immunoglobulin G1 concentration in colostrum from holstein cows. J. Dairy Sci. 74:2336-2341.

Rastani, R. R., R. R. Grummer, S. J. Bertics, A. Gümen, M. C. Wiltbank, D. G. Mashek, and M. C. Schwab. 2005. Reducing dry period length to simplify feeding transition cows: milk production, energy balance, and metabolic profiles. J. Dairy Sci. 88:1004-1014.

Santschi, D. E., D. M. Lefebvre, R. I. Cue, C. L. Girard, and D. Pellerin. 2011a. Completelactation milk and component yields following a short (35-d) or a conventional (60-d) dry period management strategy in commercial Holstein herds. J. Dairy Sci. 94:2302-2311.

Santschi, D. E., D. M. Lefebvre, R. I. Cue, C. L. Girard, and D. Pellerin. 2011b. Incidence of metabolic disorders and reproductive performance following a short (35-d) or conventional (60-d) dry period management in commercial Holstein herds. J. Dairy Sci. 94:3322-3330.

Sinyakov, M. S. and R. R. Avtalion. 2009. Vaccines and natural antibodies: A link to be considered. Vaccine. 27:1985-1986. 
Sinyakov, M. S., M. Dror, H. M. Zhevelev, S. Margel, and R. R. Avtalion. 2002. Natural antibodies and their significance in active immunization and protection against a defined pathogen in fish. Vaccine. 20:3668-3674.

Srinivasan, A., Y. Ni, and I. Tizard. 1999. Specificity and prevalence of natural bovine antimannan antibodies. Clin. Diagn. Lab. Immunol. 6:946-952.

Star, L., K. Frankena, B. Kemp, M. G. B. Nieuwland, and H. K. Parmentier. 2007. Natural humoral immune competence and survival in layers. Poultry. Sci. 86:1090-1099.

Stelwagen, K., E. Carpenter, B. Haigh, A. Hodgkinson, and T. Wheeler. 2009. Immune components of bovine colostrum and milk. J. Anim. Sci. 87:3-9.

Sun, Y., H. K. Parmentier, K. Frankena, and J. J. van der Poel. 2011. Natural antibody isotypes as predictors of survival in laying hens. Poultry. Sci. 90:2263-2274.

Thornton, B. P., V. Větvička, and G. D. Ross. 1994. Natural antibody and complementmediated antigen processing and presentation by B lymphocytes. J. Immunol. 152:1727-1737.

Tomer, Y. and Y. Shoenfeld. 1988. The significance of natural autoantibodies. Immunol Investig. 17:389-424.

Ujvari, B. and T. G. Madsen. 2011. Do natural antibodies compensate for humoral immunosenescence in tropical pythons?. Funct Ecology. 25:813-817.

Van Knegsel, A. T. M., G. de Vries Reilingh, S. Meulenberg, H. van den Brand, J. Dijkstra, B. Kemp, and H. K. Parmentier. 2007. Natural antibodies related to energy balance in early lactation dairy cows. J. Dairy Sci. 90:5490-5498.

Van Knegsel, A. T. M., G. J. Remmelink, S. Jorjong, V. Fievez, and B. Kemp. 2014. Effect of dry period length and dietary energy source on energy balance, milk yield, and milk composition of dairy cows. J. Dairy Sci. 97:1499-1512.

Van Knegsel, A. T. M., S. G. A. van der Drift, J. Čermáková, and B. Kemp. 2013. Effects of shortening the dry period of dairy cows on milk production, energy balance, health, and fertility: A systematic review. Vet. J. 198:707-713.

Watters, R. D., J. N. Guenther, A. E. Brickner, R. R. Rastani, P. M. Crump, P. W. Clark, and R. R. Grummer. 2008. Effects of dry period length on milk production and health of dairy cattle. J. Dairy Sci. 91:2595-2603.

Verweij, J. J., A. P. Koets, and S. W. F. Eisenberg. 2014. Effect of continuous milking on immunoglobulin concentrations in bovine colostrum. Animal. 160:225-229.

Vollmers, H. P. and S. Brändlein. 2009. Natural antibodies and cancer. New Biotech. 25:294-298.

Zinkernagel, R. M. 2012. Immunological memory $\neq$ protective immunity. Cell. Mol. Life Sci. 69:1635-1640. 


\title{
CHAPTER 6
}

\section{Natural autoantibodies in Bos taurus calves during the first twelve weeks of life}

\author{
N. Mayasari" ${ }^{* \dagger}$, A. T. M. van Knegsel ${ }^{*}$, G. de Vries Reilingh*, \\ B. Kemp*, H. K. Parmentier*
}

\begin{abstract}
*Adaptation Physiology Group, Department of Animal Science, Wageningen University, P.O. Box 338, $6700 \mathrm{AH}$ Wageningen, the Netherlands; ${ }^{\dagger}$ Faculty of Animal Husbandry, Universitas Padjadjaran, 45363, Bandung, Indonesia
\end{abstract}

Veterinary Immunology and Immunophatology (2016) 178:70-78 DOI: 10.1016/j.vetimm.2016.07.001 


\subsection{Abstract}

Natural autoantibodies (NAAb) have a role in maintaining physiological homeostasis and prevention of infections, and have been found in mammalian species tested so far. Albeit NAAb levels rise with age, little is known about the origin, function, regulation and initiation of NAAb in young animals. The present study addressed the presence of IgM and IgG NAAb binding glutamate dehydrogenase (GD), carbonic anhydrase (CA), myosin (MYO) and transferrin (TRANS) from before drinking colostrum until the first 12 weeks of life in plasma of female calves. In addition, NAAb to these 4 self-antigens were also measured in colostrum and in plasma of their mothers during 3 weeks before calving. Titers of NAAb binding GD, CA, MYO and TRANS were detected in plasma of cows before calving, in colostrum, and in plasma of calves before and after drinking of colostrum. Levels of NAAb in colostrum were positively related with levels of $\mathrm{NAAb}$ in plasma of cows. Before colostrum intake, levels of NAAb in plasma of calves were not related with levels of NAAb in plasma of their mother but were influenced by parity of their mother. After colostrum intake, levels of NAAb in plasma of calves in the first week of life were positively related with levels of $\mathrm{NAAb}$ in colostrum. Low NAAb levels in colostrum were related with low NAAb in plasma of calves in the first week of life, but after 2 weeks of life the relation between colostrum and plasma of calves was absent. In conclusion, NAAb are already present in the unborn calf, and levels of neonatal NAAb during the early weeks of life are affected by levels of maternal NAAb obtained via colostrum.

Key words: autoantibodies, calf, colostrum, maternal antibody transfer, dry period. 


\subsection{Introduction}

Natural antibodies (NAb) are a humoral part of innate immunity (Matter and Ochsenbein, 2008, Vollmers and Brändlein, 2009), and have been proposed to be involved in preventing infection and maintenance of physiological homeostasis (Ehrenstein and Notley, 2010, Lutz, 2012). Natural antibodies are polyreactive with low affinity binding with various antigens (Casali and Notkins, 1989), and are present in healthy animals in the absence of antigen stimulation (Avrameas, 1991, Baumgarth et al., 2005). Natural antibodies have been divided into 2 classes: overt and cryptic NAb. Overt NAb bind antigens that the individual has never encountered before, such as keyhole limpet hemocyanin (KLH). Cryptic NAb or so-called natural autoantibodies (NAAb) are antibodies that bind to self-antigens or slightly changed self-antigens (neo-epitopes). Natural autoantibodies are thought to be involved in inactivation of cytokines, prevention of inflammation, clearance of metabolic waste, perform various homeostatic roles within the immune response (Cojocura et al., 2009), and have a role in the prevention of autoimmunity (Nguyen et al., 2015). Antibodies binding a variety of self-antigens such as myosin, thyroglobulin (Lutz et al., 2009), heat shock proteins (Cohen, 2013), solubilized extracts of histologically normal organs were found in humans (Stahl et al., 2000) and in healthy calves (Khobondo et al., 2015). In dairy cows, NAb binding exoantigens (Ploegaert et al., 2011, Thompson-Crispi et al., 2013, Mayasari et al., 2015) as well as self-antigens (Van Knegsel et al., 2012) were described earlier. Little is known of the routes that lead to the production of NAAb in healthy young individuals. It was proposed that NAAb may arise by cross reactivity with the intestinal microflora (Kamada et al., 2013), are initiated by dietary compounds, directed to neo-epitopes (Lutz et al., 2009, 2012), rest on random VDJ recombination in B-cells maintained by self-antigens (Quintana and Cohen., 2004), or reflect levels of maternal antibodies after consumption of colostrum or milk. In dairy cows, maternal antibodies are not actively transferred to the fetus before birth, but calves obtain maternal antibodies passively from the dam through colostrum during the first 24 hours of life. Thus, after first colostrum intake antibody titers in calves likely reflect maternal antibody titers in colostrum during the first weeks of life until neonatal antibody production starts. Until start of neonatal antibody production, adequate and sufficient passive immune transfer of maternal antibodies via colostrum intake provide immune competence of calves, which is a prerequisite to lower the risk of diseases and infections during the preweaning period (Oliveira et al., 2010). 
To our knowledge, little information is present about the presence of NAAb in colostrum and naïve calves and the relation between NAAb levels in cows and their calves during the early weeks of life. Earlier, we studied health and energy metabolism in cows with different dry period lengths. Omission of the dry period in dairy cows reduced NAb titers in colostrum compared with cows with a short (30-d) or conventional dry period (60-d) (Mayasari et al., 2015). Moreover, lower $\mathrm{NAb}$ titers in colostrum were reflected by lower titers of NAb binding keyhole limpet hemocyanin (KLH) and human serum albumin (HuSA) in plasma of calves in the first 2 weeks of life. No IgM and IgG NAb binding KLH or HuSA were detected in plasma of calves before colostrum intake. In the present study, we evaluated the level of NAAb to 4 self-antigens: glutamate dehydrogenase (GD), carbonic anhydrase (CA), myosin (MYO) and transferrin (TRANS) in plasma of calves before and after colostrum intake, and in plasma and in colostrum of their mother. Antibodies to those 4 self-antigens were found in plasma of dairy cows. Previous studies reported that self-antibodies to GD (Schulz et al., 2014) and CA (Puscas et al., 2001) are related with metabolic and health disorders in mammals. Cows with subclinical ketosis had higher non esterified fatty acid concentration and GD activation after calving (Schulz et al., 2014). Carbonic anhydrase also functions in regulation of $\mathrm{pH}$ and fluid balance (Badger and Price, 1994) as observed during inflammation (Mihaylova et al., 2008). Another study reported that NAAb binding MYO and TRANS in milk of cows were associated with sensitivity for mastitis (Van Knegsel et al., 2012). Myosin is a fibrous protein which has a role in muscle contraction (Schmitt., 1968). Transferrin is a serum globulin which works in the complexing and transport of iron (Crichton and Charloteauxwauters., 1987).

In the current study, it was hypothesized that NAAb binding GD, CA, MYO and TRANS are present in plasma of cows and in colostrum, but absent in plasma of calves before colostrum intake. Moreover, if omission of the dry period in cows reduced NAb titers in colostrum, NAAb titers in colostrum and in plasma of their calves may be reduced as well. Moreover, the NAAb titers in plasma of calves after colostrum intake are expected to reflect the NAAb titers of their mother (in plasma and colostrum). The present study aimed to evaluate NAAb to GD, CA, MYO and TRANS in mother and calves before and after colostrum intake until 12 weeks of age and to study relationships between these titers in mother, colostrum and the calves. 


\subsection{Materials and Methods}

\subsubsection{Experimental Design, Animals and Rations}

The Institutional Animal Care and Use Committee of Wageningen University approved the experimental protocol. The registration number of the experimental protocol is 2010026. Blood and colostrum samples originated from an experiment that was designed to evaluate the effect of dry period length and ration composition on health of cows and calves. The experimental design, treatments of dry period lengths and ration composition in cows were described earlier by Van Knegsel et al. (2014). In short, Holstein-Friesian dairy cows $(\mathrm{N}=167)$ were selected from the Dairy Campus research herd (WUR Livestock Research, Lelystad, the Netherlands) blocked according to parity, calving date, milk yield in previous lactation and body condition score (BCS), and randomly assigned to treatments. Treatment consisted of 3 dry period lengths: 0,30 or $60 \mathrm{~d}$ and 2 lactation rations (glucogenic or lipogenic ration). For the current study, female calves born to these cows $(\mathrm{N}=63)$ were monitored.

\section{Management of Cows}

Cows were housed in a freestall with slatted floor and cubicles and milked twice daily (at 0500 and 1630 h). Prepartum, dry cows received a dry cow ration and lactating cows received a lactating cow ration supporting $25 \mathrm{~kg}$ of milk per day. Forage was supplied ad libitum and consisted prepartum of grass silage, corn silage, wheat straw and a protein source (rapeseed meal or soybean meal) in a ratio of 39:25:25:11 (DM basis). Postpartum, forage consisted of grass silage, corn silage, straw, and a protein source (rapeseed meal or soybean meal) in a ratio 51:34:2:13 (DM basis). From d 10 before expected calving onwards, cows of all treatments were fed $1 \mathrm{~kg} / \mathrm{d}$ glucogenic or lipogenic concentrate and increased postcalving stepwise with $0.5 \mathrm{~kg} / \mathrm{d}$ until the concentration supply reached $8.5 \mathrm{~kg} / \mathrm{d}$. Main ingredient for glucogenic concentrate was corn and main ingredients for lipogenic concentrate were sugar beet pulp, palm kernel, and rumen protected palm oil. Concentrate and forage were supplied separately.

\section{Colostrum Sampling and Management of Calves}

Colostrum sampling and management of the calves were described earlier (Mayasari et al., 2015). Distribution of cows, colostrum sampling, plasma samples of cows, plasma samples of female calves before and after colostrum intake across dry period length treatments group are shown in Table 6.1. Colostrum was 
collected and weighed immediately after calving from each quarter of mammary gland and pooled in 1 sample per cow. Calves received the colostrum from their mother via an artificial teat. Colostrum samples $(\mathrm{N}=138 ; 10 \mathrm{~mL})$ obtained after parturition were agitated and stored at $-20^{\circ} \mathrm{C}$, until analysis.

Immediately after birth, calves were removed from the dam. When calves were born between 2200 and $0500 \mathrm{~h}(\mathrm{~N}=42)$, calves were removed from the dam at $0500 \mathrm{~h}$. Calves were weighed and within $24 \mathrm{~h}$ of life, they received $4 \mathrm{~L}$ of colostrum in 2 portions from their mother. After $24 \mathrm{~h}$ after birth, female calves were fed with milk replacer (crude protein 22\% and fat 17\%) $(2 \mathrm{x} / \mathrm{d} 2 \mathrm{~L})$. After 2 days, calves were moved to the calf raising farm and were also fed milk replacer twice a day, until 60-d of life. After the first week of life, all calves were fed the same mixture of hay and grains (Agrifirm Feed, the Netherlands) based on requirements for preweaned Holstein calves. At 60-d of life, calves were weaned from milk replacer. From 60 -d of life calves received a diet based on requirement for weaned Holstein calves. During first 2 weeks of life, calves were housed in individual hutches located approximately $60 \mathrm{~cm}$ apart. After 2 weeks, calves were kept in groups of 6 to 8 calves with straw bedding. Body weight of female calves was recorded at birth and in week 2, 4, 6, 8, 10 and 12 after birth and reported earlier (Mayasari et al., 2015). Disease incidences and treatments of the female calves were recorded during the first 12 weeks of life.

In an earlier study, we evaluated the effect of maternal dry period on specific antibody responses (SpAb) to keyhole limpet hemocyanin (KLH) and human albumin serum (HuSA) in plasma of calves (Mayasari, et al 2015). Therefore, calves received primary and secondary immunizations with KLH and HuSA in week 6 and 10, respectively. Briefly, after 6 weeks of life, primary SpAb titers binding KLH and HuSA did not differ between calves from cows with different dry period lengths. However, secondary antibody responses were enhanced in calves from cows with a 0-d dry period (Mayasari et al., 2015).

\subsubsection{Blood Sampling}

For cows, blood samples were taken from the tail vain for NAAb measurement ( $\mathrm{N}=92$ cows), weekly from week -3 till -1 relative to calving. For calves, blood samples were taken from jugular vein for NAAb measurement at several time points : before colostrum intake $(\mathrm{N}=52)$, after colostrum intake at day $2($ after $24 \mathrm{~h})(\mathrm{N}=59)$ and every Wednesday in weeks 1, 2, 4, 6, 7, 8, 10, 11, and 12 of life $(\mathrm{N}=63)$. Blood samples were taken in Vacutainer tubes $(10 \mathrm{~mL}$; Greiner 
Bio-One $\mathrm{GmbH}$, Kremsmunster, Austria) containing heparin as anticoagulant. Blood samples were centrifuged at $3000 \times g$ at $4^{\circ} \mathrm{C}$, for 15 min within $2 \mathrm{~h}$ after collection. Plasma was transferred and stored at $-20^{\circ} \mathrm{C}$ until analysis.

\subsubsection{Analysis of NAAb in Plasma of Cows, Colostrum, and Plasma of Calves}

Titers of NAAb binding the 4 self-antigens GD, CA, MYO and TRANS in plasma of calves and cows and in colostrum were measured by an indirect enzymelinked immunosorbent assay (ELISA) technique as outlined by Van Knegsel et al. (2012). In brief, plates were coated with $4 \mu \mathrm{g} / \mathrm{mL}$ of GD (G7882, Sigma), CA (C3934, Sigma), MYO (M0531, Sigma) or TRANS (T1408, Sigma), respectively, in $100 \mu \mathrm{l} /$ well. Natural autoantibodies of the IgG isotype were detected either using 1:20,000 (cow) or 1:40.000 (calf, colostrum) diluted sheep polyclonal anti-bovine IgG-heavy chain conjugated to horseradish peroxidase (PO) (Cat. No. E10-118P, Bethyl, Laboratories). Natural autoantibodies of the IgM isotype in plasma of cows and calves and in colostrum were detected using 1:20,000 diluted rabbit polyclonal anti-bovine IgM-whole molecule conjugated to horseradish PO (Cat. No. A10$100 \mathrm{P}$, Bethyl, Laboratories). Four step serial dilutions for both IgG and IgM in colostrum and in plasma samples of cows and calves started at 1:40. After washing, a substrate containing tetra methyl benzidine (Sigma Aldrich Chemie, Steinheim, Germany) and 0.05 percent hydrogen peroxide was added, and incubated for 10 min at room temperature. The reaction was stopped by adding $1.25 \mathrm{M}$ sulfuric acid. Extinctions were measured with a Multiskan reader (Lab Systems, Helsinki, Finland) at a wavelength of $450 \mathrm{~nm}$. Titers were expressed as $\log 2$ values of the dilutions that gave an extinction closest to 50 percent of Emax, where Emax represents the highest mean extinction of a standard positive (pooled) serum present on every microtiter plate (Ploegaert et al., 2007).

\subsubsection{Statistical Analysis}

All data of NAAb titers in cows (plasma and colostrum) and in plasma of calves approximated normality of residuals by examining whether skewness and kurtosis were in a range of -2 until 2. Moreover, the data was analysed using PROC MIXED in SAS 9.2 (SAS Inst. Inc. Cary, NC). The NAAb titers for IgG and IgM binding GD, CA, MYO and TRANS in plasma of cows before calving were analysed with dry period length ( 0,30 or $60 \mathrm{~d}$ ), parity (1,2 or $>2$ ), week (week -3 till -1 relative to calving), and their 2 way-interactions included as fixed effect. Cow was considered as the repeated subject. A first order auto-regressive [AR (1)] variance- 
covariance structure was the best fit according to Akaike's corrected information criterion (Model 1). The NAAb titers for IgG and IgM binding GD, CA, MYO and TRANS in colostrum and in plasma of calves before colostrum intake were analysed with dry period length $(0,30$ or $60 \mathrm{~d})$, parity of the cow $(2,3$ or $>3)$ and their 2-way interaction included as fixed effect (Model 2).

The NAAb titers for IgG and IgM binding GD, CA, MYO and TRANS after colostrum intake (week 0 until 6 ) and specific antibody titers after primary (week 6 until 10) and secondary immunization (week 10 until 12) in plasma were analysed with dry period length $(0,30$ or $60 \mathrm{~d})$, parity $(2,3$ or $>3)$, week $(1,2, \ldots$ or 12$)$ and their 2-way interactions included as fixed effects. Calf was considered as the repeated subject. A first order auto-regressive variance-covariance structure was determined to be the best fit according to Akaike's corrected information criterion (Model 3). To compare dry period length effects, $P$-values are presented after a Bonferroni adjustment. Values are presented as least squares means (LSM) with their pooled standard errors of the mean (SEM), unless otherwise stated. Preliminary result showed primary and secondary immunization (in week 6 and 10, respectively) of KLH and HUSA did not affect the titers for IgG and IgM binding GD, CA, MYO and TRANS.

To assess the relationship between NAAb titers in plasma of cows with NAAb titers in colostrum or with NAAb titers in plasma of female calves (before and after colostrum intake), the average NAAb of the cows was included as continuous variable in model 2 with all 2-way interactions (Model 4). Model 4 was applied for 4 different time periods and the availability of plasma in cows and their female calves; (1) titers before colostrum intake (naïve calves) $(\mathrm{N}=27)$, (2) titers after colostrum intake at day 2 (after $24 \mathrm{~h})(\mathrm{N}=32)$, (3) the average titers in weeks 1 and $2(\mathrm{~N}=34)$, and (4) the average titers in weeks 4 till 12 of life $(\mathrm{N}=34)$. Preliminary analysis showed there was no interaction between NAAb titers in cows and dry period length, therefore this interaction was excluded from the model. To assess the relationship between NAAb titers in colostrum with NAAb titers in plasma of calves after colostrum intake, the NAAb titers in colostrum was included as continuous variable in model 3 with all 2-way interactions (Model 5). The regression coefficients $(\beta)$ from the statistical model and the $P$-value corresponding to the $\beta$ are displayed.

\subsection{Results}

Natural autoantibody (NAAb) titers for isotypes $\operatorname{IgG}$ and $\operatorname{IgM}$ binding glutamate dehydrogenase (GD), carbonic anhydrase (CA), myosin (MYO), and 
transferrin (TRANS) were detected in plasma of cows before calving (Table 6.2), in colostrum (Figure 6.1) and in plasma of calves before and after colostrum intake (Figure 6.2 and Table 6.3).

\subsubsection{Natural Autoantibodies in Plasma of Cows before Calving (Model 1)}

From week 3 till 1 before calving, cows with a 30-d dry period had higher plasma titers of IgG binding GD and IgM binding CA compared with cows with a 60-d dry period (Table 6.2). There was a dry period length $\times$ week interaction for titers of IgG binding GD and CA $(P<0.05)$. Cows with a $60-d$ dry period had lower IgG binding GD or CA a week before calving compared with week 2 or 3 before calving (GD; 8.2 vs. 8.0 vs. $7.3 \pm 0.03$, CA; 6.3 vs. 6.0 vs. $5.5 \pm 0.2$ for weeks -3 vs. -2 vs. -1 ). Cows with a 0 -d dry period or cows with a $30-d$ dry period had no difference of IgG binding GD or CA titers between different weeks prepartum. Titers of IgM binding CA and IgM binding TRANS decreased with parity (CA; 6.5 vs. 6.3 vs. $5.8 \pm 0.1$, TRANS 6.9 vs. 6.5 vs. $5.4 \pm 0.1$ for parity 1 vs. 2 vs. $>2$, respectively).
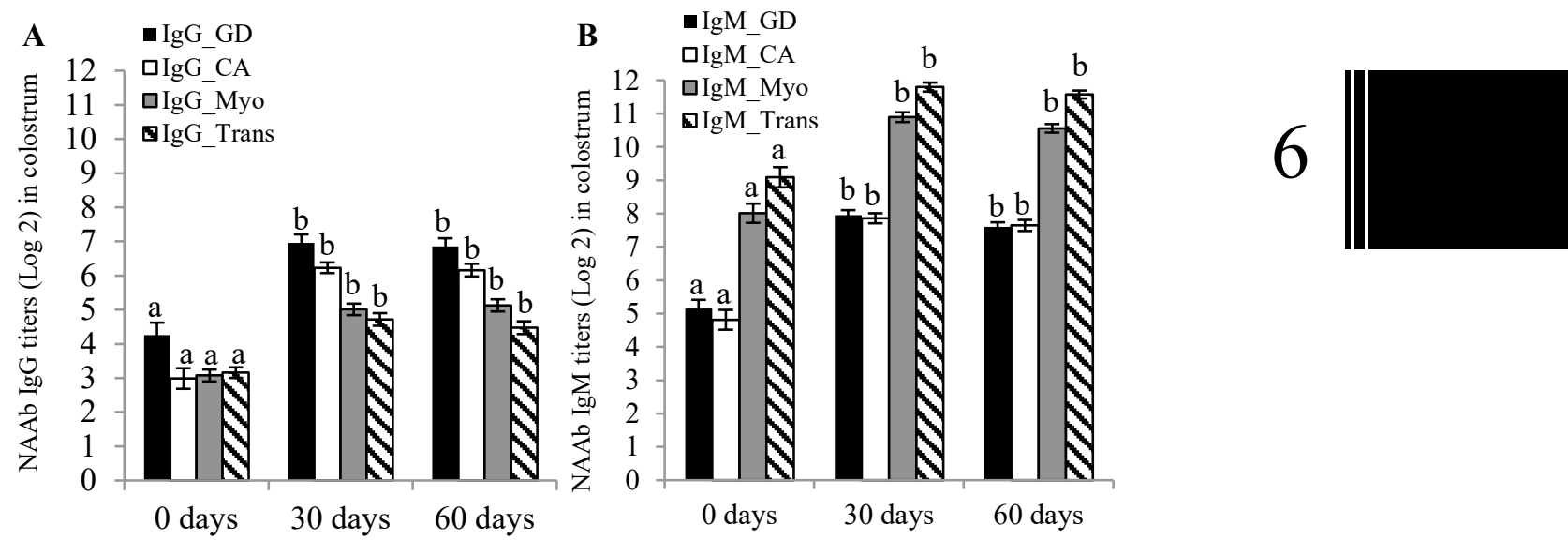

Figure 6.1 Natural autoantibodies titers ( $\log 2)$ for isotype $\operatorname{IgG}(\mathrm{A})$ and $\operatorname{IgM}(\mathrm{B})$ titers binding glutamate dehydrogenase (GD), carbonic anhydrase (CA), myosin (MYO) and transferrin (TRANS) in colostrum from dairy cows with different dry period lengths $(0,30$ or $60 \mathrm{~d}$ ) (Means \pm SEM). a, b, c values between dry period length with different superscripts differ $(P<0.05)$.

\subsubsection{Natural Autoantibodies in Colostrum (Model 2)}

Cows with a 0-d dry period had lower titers for both IgM and IgG NAAb binding GD, CA, MYO and TRANS in colostrum compared with cows with a 30-d 
or 60-d dry period (Figure 6.1). A dry period length $\times$ parity interaction was present for both titers of IgM binding GD and CA $(P<0.05)$. Older cows (parity $\geq$ 3 ) had higher titers of IgM binding GD and CA when cows had 0-d dry period compared with younger cows (GD; 4.4 vs. 5.4 vs. $5.8 \pm 0.4 \mathrm{CA} ; 4.0$ vs. 5.3 vs. 5.3 \pm 0.5 for parity 2 vs. 3 vs. $>3$, respectively). Contrary, older cows had lower titers of IgM binding GD and CA when cows had a 60-d dry period compared with younger cows (GD; 7.9 vs. 7.5 vs. $7.3 \pm 0.3 \mathrm{CA} ; 8.1$ vs. 7.4 vs. $7.4 \pm 0.3$ for parity 2 vs. 3 vs. $>3$, respectively).

Table 6.1 Distribution of cows, colostrum samples, plasma in cows and plasma of female calves (before and after colostrum intake) across the dry period length.

\begin{tabular}{lcccc}
\hline & \multirow{2}{*}{$\mathrm{N}$} & \multicolumn{3}{c}{ Dry period length } \\
\cline { 3 - 5 } & & $0 \mathrm{~d}$ & $30 \mathrm{~d}$ & $60 \mathrm{~d}$ \\
\hline Cows in the experiments & 167 & 56 & 55 & 56 \\
Colostrum & 138 & 44 & 45 & 49 \\
Plasma of cows (before calving) & 92 & 30 & 32 & 30 \\
Plasma of female calves before colostrum intake & 52 & 19 & 16 & 17 \\
Plasma of female calves after colostrum intake & 63 & 23 & 19 & 21 \\
\hline
\end{tabular}

\subsubsection{Natural Autoantibodies in Plasma of Calves before Colostrum Intake (Model 2)}

Natural autoantibodies for both isotypes (IgG and IgM) binding GD, CA, MYO and TRANS were detected in plasma of calves at birth before colostrum intake (Figure 6.2 and Table 6.2). Dry period length of the mother did not affect $\mathrm{NAAb}$ titers in calves before colostrum intake. Before colostrum intake, calves from younger cows had higher titers of IgM binding GD and MYO in plasma compared with calves from older cows (GD; 2.1 vs. 1.1 vs. $1.3 \pm 0.1$, MYO; 4.2 vs. 2.7 vs. $2.4 \pm 0.1$ for parity 1 vs. 2 vs. $>2$, respectively, $P<0.05$ ).

\subsubsection{Natural Autoantibodies in Plasma of Calves after Colostrum Intake (Model 3)}

After colostrum intake (week 1) until immunizations of KLH and HuSA at week 6 of life, NAAb for isotypes IgG and IgM binding GD, CA, MYO and TRANS in plasma of calves were affected by dry period treatment of the mother especially in the first 2 weeks of life (Figure 6.2). Primary and secondary immunizations of KLH and HuSA in week 6 and 10 of life did not affect NAAb titers for IgG and IgM binding GD, CA, MYO or TRANS in plasma of calves. After colostrum intake (week 1) until 6 weeks of life, calves from cows with a 0-d 
dry period had lower NAAb IgG and IgM binding GD, CA, MYO and TRANS in plasma compared with calves from cows with a 60-d (Table 6.2). Calves from cows with a 30-d dry period had no difference in IgM and IgG NAAb titers binding GD, CA, MYO or TRANS in plasma compared with calves from cows with a 60-d dry period, except for IgG binding MYO. From week 1 until 6 of life, NAAb for isotypes IgG and IgM binding GD, CA, MYO and TRANS in plasma of calves were affected by dry period and week interaction.

\subsubsection{Relationship between NAAb Titers in Plasma of Cows and NAAb Titers in Colostrum and in Plasma of Calves before Colostrum Intake (Model 4) \\ NAAb titers (IgG and IgM) binding GD, CA, MYO and TRANS in plasma} of cows before calving were all positively related with NAAb titers (IgG and IgM) binding GD, CA, MYO and TRANS in colostrum (Table 6.4). There were no relationships between NAAb titers to 4 self-antigens in plasma of cows before calving with NAAb titers to 4 self-antigens in plasma of their calves before colostrum intake.

\subsubsection{Relationship between NAAb Titers in Plasma of Cows and NAAb Titers in Plasma of Calves after Colostrum Intake (Model 4)}

Titer of IgG binding CA in plasma of calves after colostrum intake at day 2 was positively related with titer of IgG binding CA in plasma of cows (Table 6.4). The other titers were not correlated. In weeks 1 and 2 after birth, titers of $\operatorname{IgG}$ binding GD, CA and TRANS in plasma of calves were positively related with titers of IgG binding GD, CA and TRANS in plasma of cows. However, NAAb titers in plasma of calves from week 4 until 12 of life were not related with NAAb titers in plasma of cows.

\subsubsection{Relationship between NAAb titers in Colostrum and in Plasma of Calves after Colostrum Intake (Model 5)}

Titers of NAAb (IgG and IgM) binding GD, CA, MYO and TRANS in colostrum correlated positively with titers of NAAb (IgG and IgM) binding GD, CA, MYO and TRANS in plasma of calves after colostrum intake (at d 2) (Table 6.5). No relations were found between NAAb titers present in colostrum and $\mathrm{NAAb}$ titers in plasma of calves after 2 weeks of life. 

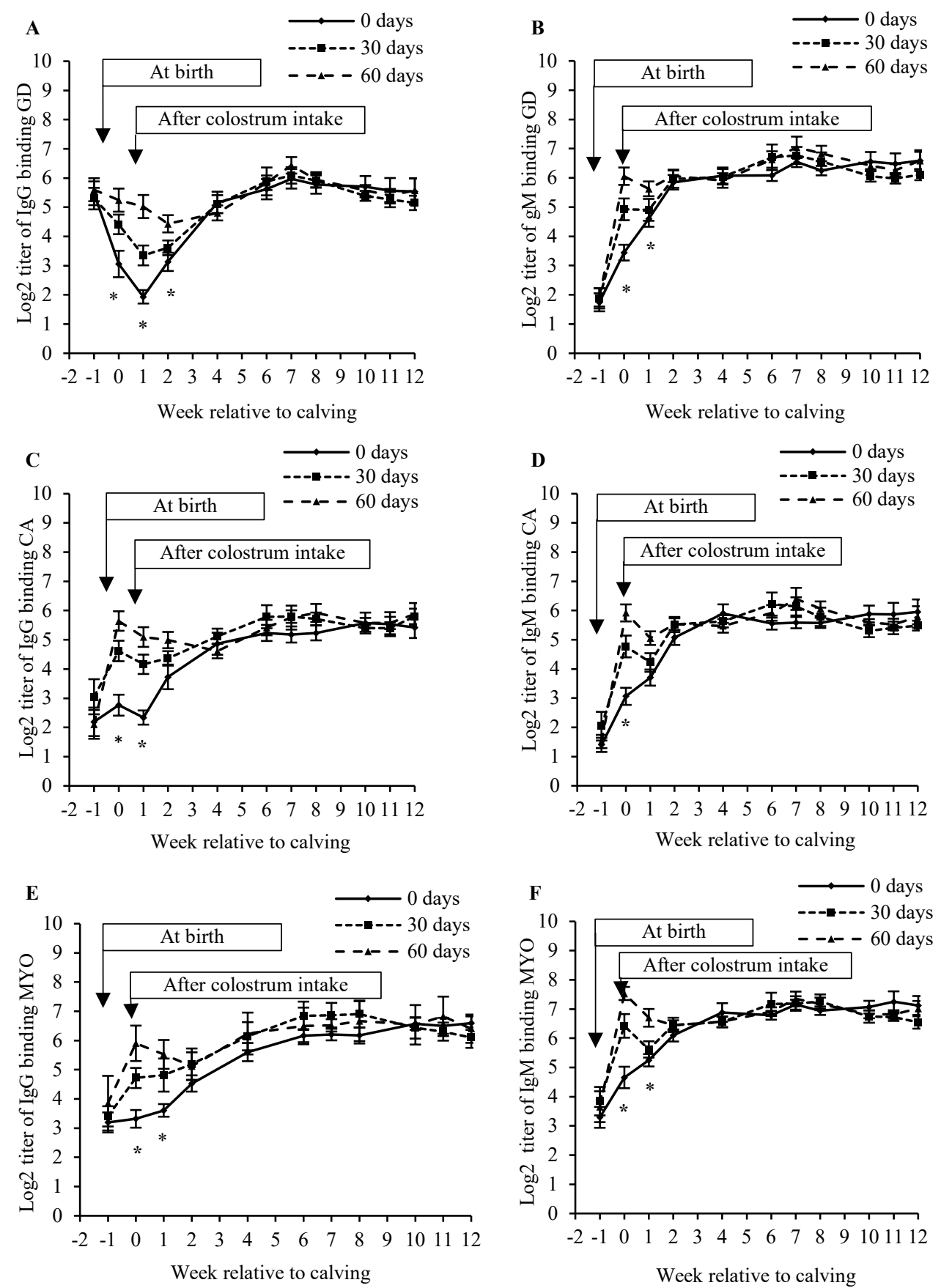

Continued to the next page 

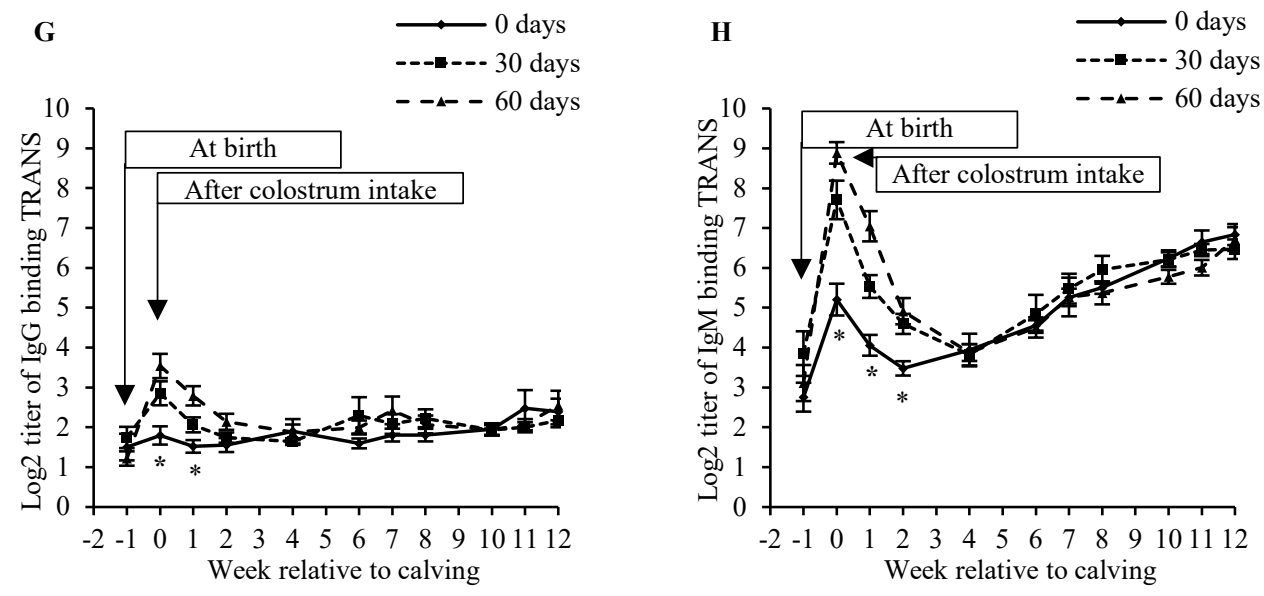

Figure 6.2 Plasma natural autoantibodies (IgG and IgM) titers binding glutamate dehydrogenase (GD; A and B), carbonic anhydrase (CA; C and D), myosin (MYO; E and F) and transferrin (TRANS; $\mathrm{G}$ and $\mathrm{H}$ ) of calves at birth (before colostrum intake), after drinking colostrum from cows with 3 different dry period lengths $(0,30$, or $60 \mathrm{~d})$. Values are means $\left( \pm\right.$ SEM) per dry period length (DP) per week $(\mathrm{W}) .{ }^{*} P$-value $<0.05$. 


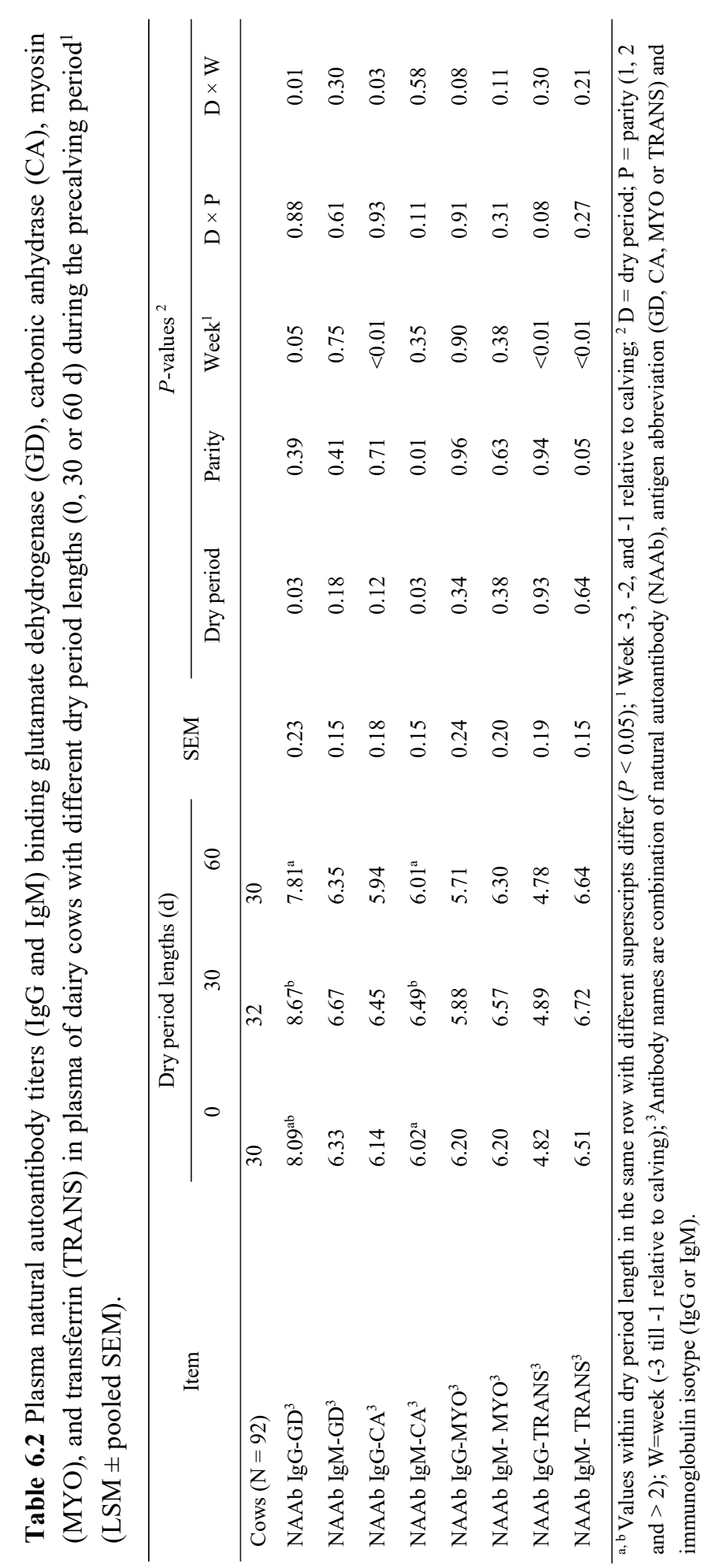




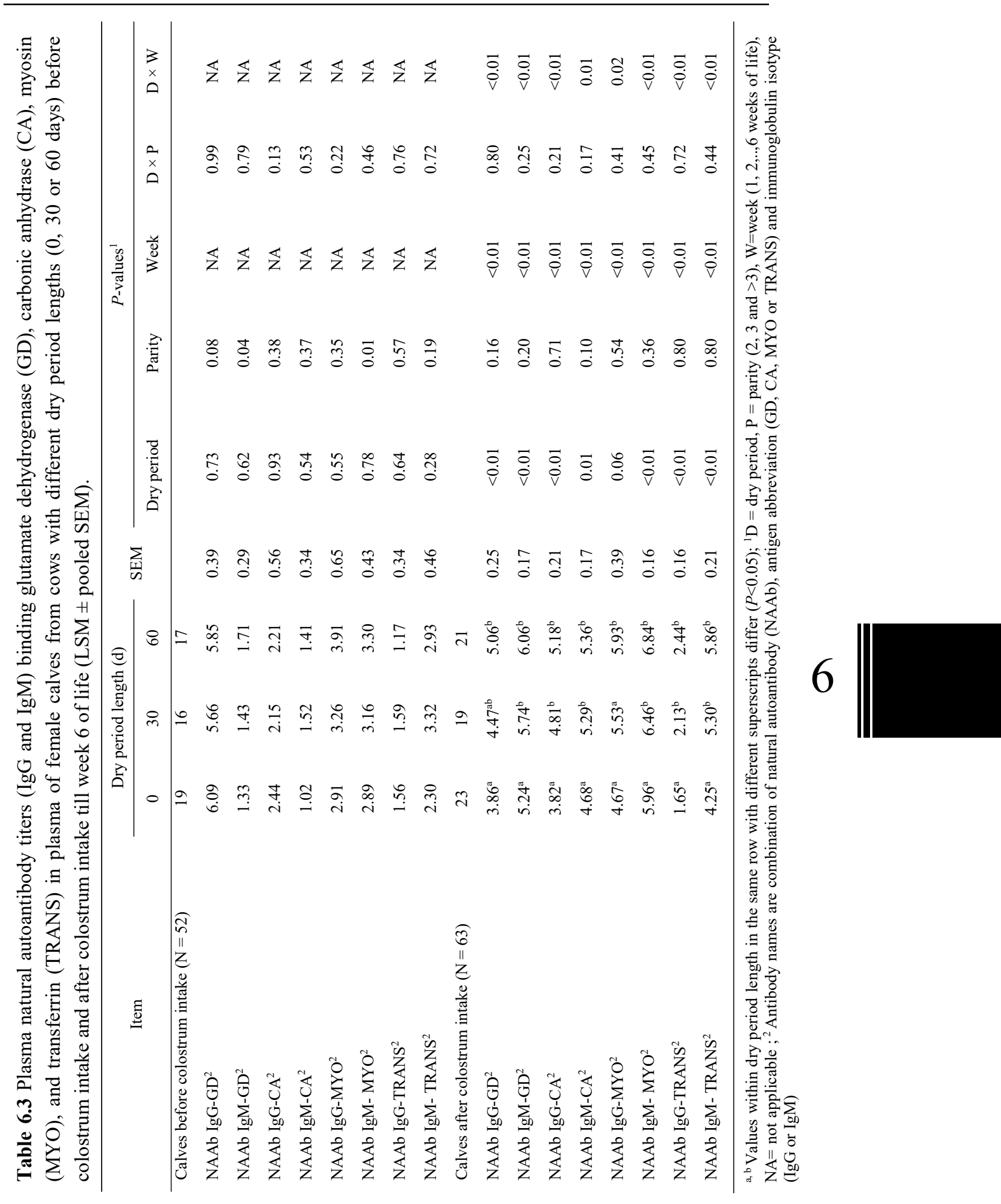


Table 6.4 Relationship between the average titers of natural auto antibodies (NAAb) binding glutamate dehydrogenase (GD), carbonic anhydrase (CA), myosin (MYO), and transferrin (TRANS) in plasma of cows before calving ${ }^{1}$ with NAAb in colostrum, $\mathrm{NAAb}$ in plasma of calves before colostrum intake and after colostrum intake ${ }^{2}$. Values represent regression coefficients $(\beta)$ and $P$-value.

\begin{tabular}{|c|c|c|c|c|c|}
\hline & \multirow{2}{*}{$\mathrm{n}^{4}$} & \multicolumn{4}{|c|}{ Cows (week -3 until -1 relative to calving) ${ }^{1,3}$} \\
\hline & & IgG_GD & IgM_GD & IgG_CA & IgM_CA \\
\hline Colostrum & 74 & $0.454(0.01)$ & $0.364(0.02)$ & $0.388(0.02)$ & $0.570(<0.01)$ \\
\hline $\begin{array}{l}\text { Calves (before colostrum } \\
\text { intake) }\end{array}$ & 26 & $0.541(0.09)$ & $-0.403(0.26)$ & $-0.805(0.13)$ & $-0.376(0.20)$ \\
\hline $\begin{array}{l}\text { Calves (after } \\
\text { colostrum } \\
\text { intake at d 2) }\end{array}$ & 32 & $0.220(0.42)$ & $0.336(0.31)$ & $0.690(0.05)$ & $0.531(0.09)$ \\
\hline $\begin{array}{l}\text { Calves (week 1-2 } \\
\text { weeks of life) }\end{array}$ & 34 & $0.360(0.05)$ & $0.168(0.41)$ & $0.482(0.04)$ & $0.012(0.96)$ \\
\hline Calves ( $4-12$ weeks of life) & 34 & $-0.134(0.46)$ & $0.126(0.54)$ & $0.192(0.35)$ & $-0.077(0.69)$ \\
\hline
\end{tabular}

Table 6.4 Continued

\begin{tabular}{lccccc}
\hline & $\mathrm{n}^{4}$ & \multicolumn{4}{c}{ Cows (week -3 until -1 relative to calving) } \\
\cline { 3 - 6 } & 74 & $0.846(<0.01)$ & $0.482(<0.01)$ & $0.533(<0.01)$ & $0.467(0.01)$ \\
\hline Colostrum & 26 & $-0.189(0.50)$ & $0.131(0.71)$ & $-0.466(0.07)$ & $0.297(0.42)$ \\
$\begin{array}{l}\text { Calves (before } \\
\text { colostrum } \\
\begin{array}{l}\text { intake) } \\
\text { Calves (after }\end{array}\end{array}$ & 32 & $0.393(0.11)$ & $0.325(0.13)$ & $0.364(0.07)$ & $0.702(0.09)$ \\
$\begin{array}{l}\text { colostrum } \\
\text { intake at day 2) } \\
\begin{array}{l}\text { Calves (week 1-2 } \\
\text { weeks of life) }\end{array}\end{array}$ & 34 & $0.193(0.24)$ & $0.029(0.82)$ & $0.243(0.02)$ & $0.363(0.11)$ \\
$\begin{array}{l}\text { Calves (4-12 } \\
\text { weeks of life) }\end{array}$ & 34 & $-0.090(0.51)$ & $0.099(0.32)$ & $0.128(0.30)$ & $-0.074(0.68)$ \\
\hline
\end{tabular}

${ }^{1} \mathrm{NAAb}$ titers in plasma of cows are the average titer in weeks -3 till -1 relative to calving. ${ }^{2}$ Calves were classified based on weeks to NAAb (titer before colostrum intake, titer after colostrum intake at day 2 (after $24 \mathrm{~h}$ ), the average titer in the first 2 weeks (week1 and 2) and the average titer in weeks 4 till 12 of life). ${ }^{3}$ Antibody names are combination of natural autoantibody (NAAb), antigen abbreviation (GD, CA, MYO, or TRANS) and immunoglobulin isotype (IgG or IgM). ${ }^{4}$ Samples available in plasma of cows and colostrum $(\mathrm{n}=74,0-\mathrm{d}=21 ; 30-\mathrm{d}=25$ and $60-\mathrm{d}=28)$ and in calves (in several time points: plasma of calves before colostrum intake $(n=26,0-d=8 ; 30-d=10$ and $60-d=8)$, plasma of calves after colostrum intake (at day 2$)(\mathrm{n}=32,0-\mathrm{d}=11 ; 30-\mathrm{d}=10$ and $60-\mathrm{d}=11)$, plasma of calves after colostrum in week 1 and 2, plasma of calves after colostrum intake from week 4 till $12(\mathrm{n}=34,0-\mathrm{d}=12 ; 30-\mathrm{d}=11$ and $60-\mathrm{d}=$ 11) 


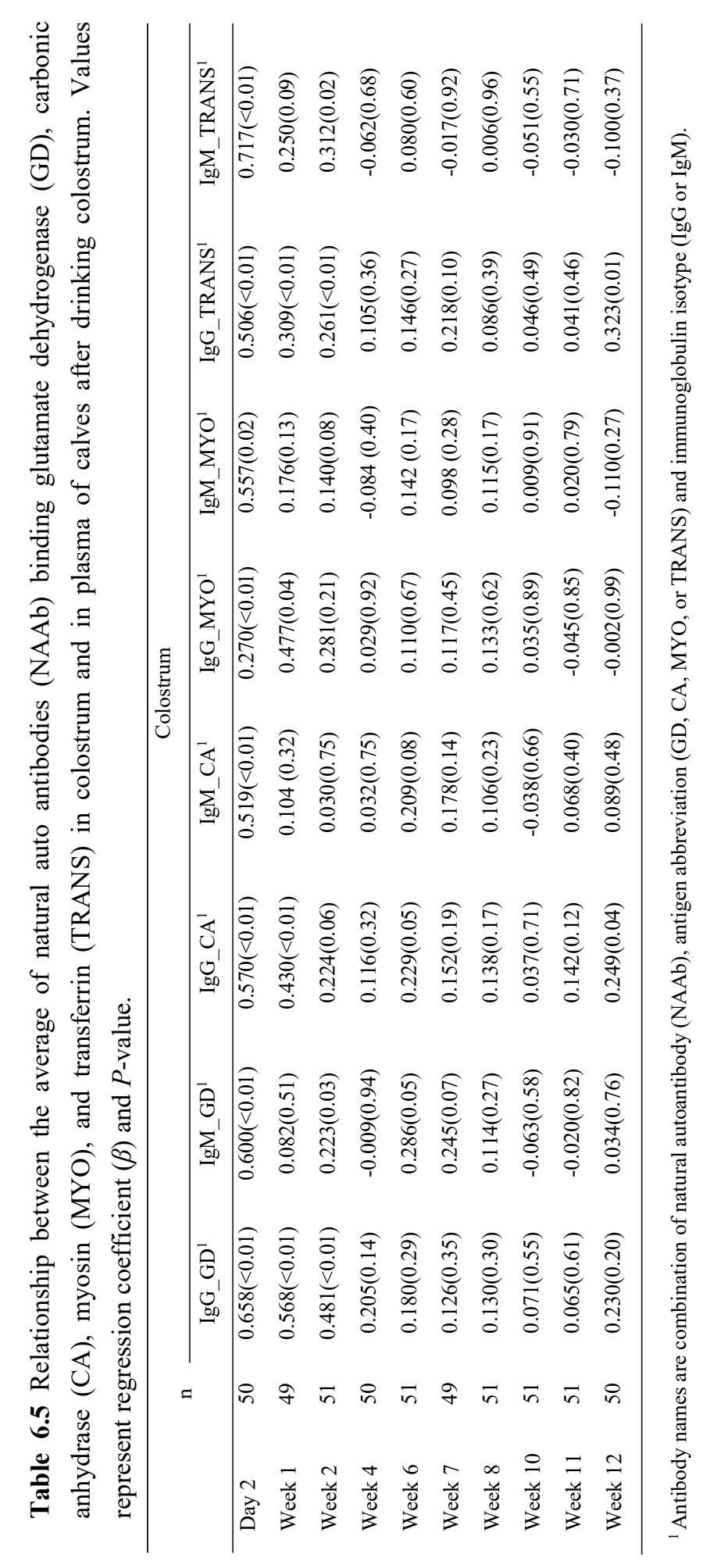




\subsection{Discussion}

In the present study IgM and IgG antibodies binding 4 self-antigens: GD, CA, MYO and TRANS, were detected in plasma of cows before calving, in colostrum, and in plasma of their calves both before and after colostrum intake. Previous studies showed that antibodies reacting to self-antigens can be found in plasma and milk from healthy non-immunized dairy cows (Van Knegsel et al., 2012) and in plasma from calves of 20-26 of weeks old (Khobondo et al., 2015). Together, these findings show that NAAb are present in young and old dairy cows.

The present study showed that NAAb of both antibody isotypes (IgG and IgM) binding GD, CA, MYO and TRANS were present in plasma of calves before colostrum intake. Earlier, NAb binding the exo-antigens KLH and HuSA were found in plasma from calves after colostrum intake but not before colostrum intake (Mayasari et al., 2015). The study of Mayasari et al. (2015) suggested that NAb binding exo-antigens during the first weeks of life depend on maternal transfer via colostrum and subsequent sensitization to environmental antigens, whereas the current study suggest that NAAb may be already initiated by self-antigens during the fetal phase. Knowledge of origin, induction and transfer of NAAb is scarce. The presence of NAAb may reflect cross reactivity to microbiota (Kamada et al., 2013), or represent idiotypes either initiated or maintained by self-antigens, or alternatively initiated and maintained by maternal antigens transferred from the mother to the fetus. The presence of NAAb in antigen-free mice (Haury et al., 1997), in human fetal cord blood (Lacroix-Desmazes et al., 1998) and in plasma from calves before colostrum intake (this study) suggest that NAAb do reflect auto-responsiveness. In fetal calf's, lymph nodes IgM+ cells are present at $60 \mathrm{~d}$ in gestation, and from day 130 plasma immunoglobulins are found (Schultz et al., 1973). It is tempting to speculate that auto-antigens in the fetus are involved in the production of auto-antibodies. VDJ recombinations and somatic mutations provide a large degree of antigen receptor diversification that is required to combat infections, but as a consequence high levels of autoimmune B cells are found in healthy humans (Wardemann and Nussenzweig, 2007) indicating that yet to be identified mechanisms prevent auto-immune diseases. In addition, repeated immunizations with exo-antigens in this study did not affect NAAb levels in the calves. This study confirms previous studies in man that NAAb binding autoantigens like DNA, hormones, histones, enzymes, receptors, major histocompatibility antigens, and intercellular matrix components are present in healthy individuals (Poletaev and Osipenko, 2003) even without any challenges 
and even without transfer of passive maternal antibodies via colostrum or intrauterine IgG transfer (Madi et al., 2009).

In the current study, titers of NAAb binding GD, CA, MYO and TRANS increased in plasma of calves after colostrum intake. A week after colostrum intake the levels of NAAb in plasma decreased in all calves, but especially in calves that received colostrum with lower levels of IgG binding GD and CA, and IgM binding TRANS, i.e. from cows with a 0-d dry period. Natural autoantibody titers for calves from cows with a 0-d dry period were specifically lower immediately after colostrum intake and in week one, but after 4 weeks the differences in titers between the 3 groups of calves were absent, suggesting an increased production of NAAb to GD, CA, MYO and TRANS in calves from cows with a 0 -d dry period. Earlier we suggested that the lower NAb titers in plasma in the first 2 weeks of life of calves, which were born from cows with a 0-d dry period, were likely caused by lower immunoglobulin content in colostrum (Mayasari et al., 2015). Moreover, in this earlier study NAb titers in plasma of calves from cows with a 0 -d dry period increased more between weeks 2 and 6 of age, compared with calves from cows with a 30-d or 60-d dry period. In the current study, there was no difference in the level of antibodies against self-antigens for calves from cows with a 30-d dry period, compared with calves born to cows a $60-\mathrm{d}$ dry period. This is in line with the earlier study that calves born to cows with a 30-d dry period had no differences in antibodies against exo-antigens in plasma compared with calves born to cows with a 60-d dry period (Mayasari et al., 2015). Together, these findings suggest that the dynamics of NAAb binding GD, CA, MYO and TRANS in plasma of calves after colostrum intake were similar with the dynamics of NAb binding exoantigens in calves after colostrum intake. Calves from cows with a 0-d dry period had lower NAb or NAAb in the first 2 weeks of life but eventually they had similar titers of NAb or NAAb from 6 weeks of life onwards.

In the current study, NAAb for isotypes $\operatorname{IgG}$ and IgM binding 4 autoantigens in plasma of calves increased after colostrum intake, except for IgG binding GD. We have no explanation for different behavior of IgG binding GD. Our observation suggested that calves already have NAAb before colostrum intake, which is markedly affected by colostral NAAb, but the level of IgG binding GD titers decreased very fast within a week after calves produced NAAb themselves. Since after a few weeks there were no differences anymore between the calves, it is questioned, whether NAAb have a specific function in colostrum and are selectively transfer to plasma. In addition, it is also questioned whether NAAb are 
waste products in the colostrum since calves seem to be able to make NAAb by themselves. A sudden increase in maternal antibodies may result in a response of the calf to get rid of IgG binding GD but this is all very speculative. A previous study showed that the mechanisms of low levels of antibodies in plasma after colostrum intake were either antigen specific or non-antigen specific (Banks, 1982). Another study showed that the concentration of colostral antibodies absorbed, the half-life of each class (isotypes) and the catabolism rate of each isotype determined the level of antibodies in plasma of calves (Murphy et al., 2014).

The low NAAb titers and subsequent higher increase in NAAb levels in calves from the 0-d dry period treated cows are in line with earlier studies which reported a negative relation between $\mathrm{NAb}$ and antibody responses following vaccination or immunization (Sinyakov and Avtalion., 2009). In man, colostrum of healthy mothers contains a broad spectrum of IgA (Pribylova et al., 2012, Quan et al.,1997) and IgM (Vassilev and Veleva., 1996) binding various autoantigens, which may modulate or supplement neonatal innate immunity (Pribylova et al., 2012). On the other hand, maternal antibodies, apart from protection of neonates to infection, also perform long term self-perpetuating imprinting of the neonatal Bcell repertoire by preventing development of activated self-reactive B cells by masking cross-reactive self during infections (Fink et al., 2008).

In our study, age (parity) of the mother affected the level of NAAb in plasma of calves before colostrum intake. Older cows with no dry period compared with young cows had lower IgM NAAb titers in plasma and they had higher IgM NAAb in colostrum. A previous study reported that old and young cows had no differences in NAAb in plasma or milk (Van Knegsel et al., 2012). Other studies reported that older cows had higher NAb titers binding exo-antigens like KLH and HuSA in colostrum than young cows (Muller and Ellinger, 1981, Pritchett et al., 1991, Mayasari et al., 2015). The present study is not in line with Conneely et al. (2013) who suggested that older cows have higher antibody levels because they are likely to be exposed more to a greater number of antigens in their life (Larson et al., 1980). Low NAAb in plasma of cows may result from transfer of antibodies from blood to colostrum. Furthermore, IgM NAAb in plasma of calves before colostrum intake were lower in plasma of calves from older cows. In man, several genes (e.g. $\mathrm{V}_{\mathrm{H}}$ genes) encoding some NAAb in the mother were shown to predominate in the newborn (Lacroix-Desmazes et al., 1998). In mice, the level of IgM binding self-antigens was high in plasma during fetal development and in 
newborns (Nobrega et al., 1996). Yet, we have no explanation how parity of the cows may affect the level of NAAb in plasma of their calves, because cows do not transfer antibodies to the fetus. Therefore, it is tempting to speculate that the level of NAAb in plasma of naïve calves may represent a health status biomarker of themselves or their mother.

To our best knowledge, this is the first study presenting the relationship between cows (plasma and colostrum) and their calves during the first weeks of life with respect to NAAb. In the current study, omitting the dry period resulted in lower levels of IgM binding CA in plasma of cows 3 weeks before calving and lower levels of IgG and IgM binding GD, CA, MYO or TRANS in colostrum compared with cows with a 30-d or a 60-d dry period. Earlier studies (Rastani et al., 2005, Verweij et al., 2014, Mayasari et al., 2015) reported that omission of the dry period reduced colostrum immunoglobulin contents and reduced NAb levels in colostrum at day of calving (Mayasari et., al 2015). Although titers of NAAb were detected in plasma of calves immediately after birth, the titers of NAAb in plasma of the calves before colostrum intake had no correlations with the averages of $\mathrm{NAAb}$ in plasma of their mother. The NAAb titers in plasma of calves increased directly after colostrum intake indicating that the high plasma NAAb titers in calves immediately after colostrum intake are likely derived from colostrum (Srinivasan et al., 1999). The levels of NAAb in plasma of calves during the first week of life were positively correlated with the level of NAAb in colostrum. This suggests that the level of antibodies in plasma of calves during the first weeks of life reflect the level of antibodies in colostrum and plasma of their mothers. It is suggested that $\mathrm{Fc}$ receptor mediated transfer for IgG and IgM (Lascelles, 1979, Hurley and Theil, 2011) has a role in transferring antibodies from plasma to colostrum and milk in dairy cows (Kacskovics et al., 2000). The level of NAAb in colostrum had no relation with the levels of NAAb in plasma of calves after 2 weeks of life. Low NAAb levels after colostrum intake coincided with a faster increase of NAAb levels within 3 till 4 weeks after birth. Thus, dry period treatment of cows had temporary transgenerational effects on calves. Similar with the increase of NAb to exo-antigens (Mayasari et al., 2015), calves may build up their own immune repertoire after the first 2 weeks of life regardless of their mother. In humans, high titers of NAAb binding self-antigens in plasma of the mother might reduce the incidence of diseases of their offspring (Tzioufas and Routsias, 2010). Our data indicate that the 2 weeks period in which calves received 
less colostrum from ( 0 -d dry period) mothers did not result in enhanced disease sensitivity during the 12 weeks observation period.

\subsection{Conclusions}

In conclusion, IgG and IgM antibodies binding GD, CA, MYO and TRANS were detected in plasma of cows before calving, in colostrum and in plasma of calves before and after colostrum intake. The level of NAAb in plasma of calves before colostrum intake was not affected by the level of NAAb of their mother but were affected by parity of their mothers. After colostrum intake, calves from cows with no dry period (i.e. receiving the lower amount of maternal NAAb after drinking) had a rapid increase in NAAb to similar levels as the other calves. Our data indicate that; (1) low levels of maternal NAAb in colostrum affect production of neonatal NAAb positively and (2) independent of dry period length, healthy calves reach a specific level of NAAb from 6 weeks of age. Future studies should reveal the consequences of low or high levels of (other) NAAb from either neonatal or maternal of origin on disease sensitivity of calves later in life.

\subsection{Acknowledgements}

The authors wish to thank the Dutch Dairy Board (PZ, Zoetermeer, the Netherlands), the Product Board Animal Feed (PDV, Zoetermeer, the Netherlands), and CRV (Arnhem, the Netherlands), for financing the experiment. The authors also wish to acknowledge their thanks for the scholarship of Novi Mayasari from the Directorate General of Higher Education, Ministry of National Education, Jakarta, Indonesia. The authors thank Gerrit Remmelink, Wilke Rijks, Xiaoyu Han, Mike Nieuwland, Joop Arts and staff of Dairy Campus (Lelystad, the Netherlands) for technical support during the experiment and the laboratory analysis. 


\section{References}

Avrameas, S., 1991. Natural autoantibodies: From 'horror autotoxicus' to 'gnothi seauton'. Immunol. Today 12: 154-159.

Badger, M. R., Price, G. D., 1994. The role of carbonic-anhydrase in photosynthesis. Annu. Rev. Plant Physiol. and Plant Mol. Biol. 45: 369-392.

Banks, K. L. 1982. Host defense in the newborn animal. J. Am. Vet. Med. Assoc. 181: 1053-1056.

Baumgarth, N., Tung, J. W., Herzenberg, L. A., 2005. Inherent specificities in natural antibodies: A key to immune defense against pathogen invasion. Springer Semin. Immunopathol. 26: 347-362.

Casali, P., Notkins, A. L., 1989. CD5+ B lymphocytes, polyreactive antibodies and the human B-cell repertoire. Immunol. Today 10: 364-368.

Cohen, I. R., 2013. Autoantibody repertoires, natural biomarkers, and system controllers. Trend. Immunol. 34: 620-625.

Cojocura, M., Cojocura, I. M., Silosi, I., 2009. The significance of natural autoantibodies. M-edica. 4: 22-25

Conneely, M., Berry, D., Sayers, R., Murphy, J., Lorenz, I., Doherty, M., Kennedy, E., 2013. Factors associated with the concentration of immunoglobulin $G$ in the colostrum of dairy cows. Animal: 1-9.

Coutinho, A., Kazatchkine, M. D., Avrameas, S., 1995. Natural autoantibodies. Curr. Opinion Immunol. 7: 812-818.

Crichton, R. R., Charloteauxwauters, M., 1987. Iron Transport and Storage. Eur. J. Biochem. 164: 485-506.

Ehrenstein, M. R., Notley, C. A., 2010. The importance of natural IgM: scavenger, protector and regulator. Nat. Rev. Immunol. 10: 778-786.

Fink, K., Zellweger, R., Weber, J., Manjarrez-Orduno, N., Holdener,M., Senn, B. M., Hengartner, H., Zinkernagel, R. M., Macpherson, A. J., 2008. Long-term maternal imprinting of the specific B cell repertoire by maternal antibodies. Eur. J. immunol. 38: 90-101.

Haury, M., Sundblad, A., Grandien, A., Barreau, C., Coutinho, A., Nobrega, A., 1997. The repertoire of serum IgM in normal mice is largely independent of external antigenic contact. Eur. J. Immunol. 27: 1557-1563.

Kacskovics, I., Wu, Z., Simister, N. E., Frenyó, L. V., Hammarström, L., 2000. Cloning and characterization of the bovine MHC class I-Like Fc receptor. J. Immunol. 164:1889-1897.

Kamada, N., Seo, S. G. Y., Chen, Nunez, G., 2013. Role of the gut microbiota in immunity and inflammatory disease. Nat. Rev. Immunol. 13: 321-335.

Khobondo, J. O., Nieuwland, M. G. B., Webb, L. E., Bokkers, E. A. M., Parmentier, H. K., 2015. Natural (auto) antibodies in calves are affected by age and diet. Vet. Quart. 35: 64-75.

Lacroix-Desmazes, S., Kaveri, S. V., Mouthon, L., Ayouba, A., Malanchère, E., Coutinho, A., Kazatchkine, M. D., 1998. Self-reactive antibodies (natural autoantibodies) in healthy individuals. J. Immnunol. Methods 216: 117-137.

Larson, B. L., Heary, H. L., Devery, J. E., 1980. Immunoglobulin production and transport by the mammary gland. J. Dairy Sci. 63: 665-671.

Lascelles, A. K. 1979. The immune system of the ruminant mammary gland and its role in the control of mastitis. J. Dairy Sci. 62: 154-160. 
Lutz, H. U., Binder, C. J., Kaveri, S., 2009. Naturally occurring auto-antibodies in homeostasis and disease. Trend. Immunol. 30: 43-51.

Lutz, H. U. 2012. Naturally occurring antibodies. Adv. Exp. Med. Biol. 750: 7-10.

Madi, A., Hecht, I., Bransburg-Zabary, S., Merbl, Y., Pick, A., Zucker-Toledano, M., Quintana, F.J., Tauber, A.I., Cohen, I.R., Ben-Jacob, E., 2009. Organization of the autoantibody repertoire in healthy newborns and adults revealed by system level informatics of antigen microarray data. Proc. Natl. Acad. Sci. 106: 14484-14489.

Matter, M. S., Ochsenbein, A. F., 2008. Natural antibodies target virus-antibody complexes to organized lymphoid tissue. Autoimmun. Rev. 7: 480-486.

Mayasari, N., de Vries Reilingh, G., Nieuwland, M. G. B., Remmelink, G. J., Parmentier, H. K., Kemp, B., van Knegsel, A. T. M., 2015. Effect of maternal dry period length on colostrum immunoglobulin content and on natural and specific antibody titers in calves. J. Dairy Sci. 98: 3969-3979.

Muller, L. Ellinger, D., 1981. Colostral immunoglobulin concentrations among breeds of dairy cattle. J. Dairy Sci. 64: 1727-1730.

Murphy, J. M., Hagey, J. V., Chigerwe. M., 2014. Comparison of serum immunoglobulin G half-life in dairy calves fed colostrum, colostrum replacer or administered with intravenous bovine plasma. Vet. Immun. and Immunopath. 158: 233-237.

Mihaylova, N. M., Dimitrov, J. D., Djoumerska-Alexieva, I. K., Vassilev, T. L., 2008. Inflammation-induced enhancement of IgG immunoreactivity. Inflam. Res. 57:1-3.

Nguyen, T. T. T., Elsner, R. A., Baumgarth, N., 2015. Natural IgM prevents autoimmunity by enforcing B cell central tolerance induction. J. Immunol. 194: 1489-1502.

Nobrega, A., Haury, M., Gueret, R., Coutinho, A., Weksler, M. E., 1996. The age associated increase in autoreactive immunoglobulins reflects a quantitative increase in specificities detectable at lower concentrations in young mice. Scandinavian J. Immunol. 44: 437-443.

Oliveira, R. A., Narciso, C. D., Bisinotto, R. S., Perdomo, M. C., Ballou, M. A., Dreher, M., Santos, J. E. P., 2010. Effects of feeding polyphenols from pomegranate extract on health, growth, nutrient digestion, and immunocompetence of calves. J. Dairy Sci. 93: 4280-4291.

Ploegaert, T. C. W., Reilingh, G. D. V., Nieuwland, M. G. B., Lammers, A., Savelkoul, H. F. J., and Parmentier. H. K., 2007. Intratracheally administered pathogenassociated molecular patterns affect antibody responses of poultry. Poultry Sci. 86, 1667-1676.

Ploegaert, T. C. W., Tijhaar, E., Lam, T. J. G. M., Taverne-Thiele, A., van der Poel, J. J., van Arendonk, J. A. M., Savelkoul, H. F. J., Parmentier, H. K., 2011. Natural antibodies in bovine milk and blood plasma: Variability among cows, repeatability within cows, and relation between milk and plasma titers. Vet. Immunol. and Immunopath. 144: 88-94.

Pribylova, J., Krausova, K., Kocourkova, I., Rossman, P., Klimesova, K., Kverka, M., Tlaskalova-Hogenova, H., 2012. Colostrum of healthy mothers contains broad spectrum of secretory IgA autoantibodies. J. Clin. Immunol. 32: 1372-1380.

Pritchett, L. C., Gay, C. C., Besser, T. E., Hancock, D. D., 1991. Management and production factors influencing immunoglobulin G1 concentration in colostrum from holstein cows1. J. Dairy Sci. 74: 2336-2341.

Poletaev, A. Osipenko, L., 2003. General network of natural autoantibodies as immunological homunculus (Immunculus). Autoimmun. Rev. 2: 264-271. 
Puscas, I., Coltau, M., Baican, M., Domuta, G., Hecht, A., 2001. Calcium, carbonic anhydrase and gastric acid secretion. Physiol. Res. 50: 359-364.

Quan, C. P., Berneman, A., Pires, R., Avrameas, S., Bouvet, J. P., 1997. Natural polyreactive secretory immunoglobulin A autoantibodies as a possible barrier to infection in humans. Infect. Immun. 65: 3997-4004.

Quintana, F. J., Cohen I. R., 2004. The natural autoantibody repertoire and autoimmune disease. Biomedi. Pharmacotherapy 58: 276-281.

Rastani, R. R., Grummer, R. R., Bertics, S. J., Gümen, A., Wiltbank, M. C., Mashek, D. G., Schwab, M. C., 2005. Reducing dry period length to simplify feeding transition cows: milk production, energy balance, and metabolic profiles. J. Dairy Sci. 88: 1004-1014.

Schmitt, F. O., 1968. Fibrous Proteins - Neuronal Organelles. P. Natl. Acad. Sci. USA. 60: 1092.

Schultz, R. D., Dunne, H. W., Heist, C. E., 1973. Ontogeny of the bovine immune response. Infec. and Immun. 7: 981-991.

Schulz, K., Frahm, J., Meyer, U., Kersten, S., Reiche, D., Rehage, J., Dänicke. S., 2014. Effects of prepartal body condition score and peripartal energy supply of dairy cows on postpartal lipolysis, energy balance and ketogenesis: an animal model to investigate subclinical ketosis. J. .Dairy Res. 81: 257-266.

Sinyakov, M. S. Avtalion, R. R., 2009. Vaccines and natural antibodies: A link to be considered. Vaccine 27: 1985-1986.

Srinivasan, A., Ni, Y., Tizard, I., 1999. Specificity and prevalence of natural bovine antimannan antibodies. Clin. Diagn. Lab. Immunol. 6: 946-952.

Stahl, D., Lacroix-Desmazes, S., Mouthon, L., Kaveri, S. V., Kazatchkine, M. D., 2000. Analysis of human self-reactive antibody repertoires by quantitative immunoblotting. J. Immunol. Methods. 240: 1-14.

Thompson-Crispi, K. A., Miglior, F., Mallard, B. A., 2013. Genetic parameters for natural antibodies and associations with specific antibody and mastitis in Canadian Holsteins. J. Dairy Sci. 96: 3965-3972.

Tzioufas, A. G., Routsias, J. G., 2010. Idiotype, anti-idiotype network of autoantibodies: pathogenetic considerations and clinical application. Autoimmun. Rev. 9: 631633.

Van Knegsel A.T.M., de Vries Reilingh, G., Meulenberg, S., van den Brand, H., Dijkstra, J., Kemp, B., Parmentier, H.K., 2007. Natural antibodies related to energy balance in early lactation dairy cows J. Dairy Sci: 90, 5490-5498.

Van Knegsel, A. T. M., Hostens, M., de Vries Reilingh, G., Lammers, A., Kemp, B., Opsomer, G., Parmentier, H. K., 2012. Natural antibodies related to metabolic and mammary health in dairy cows. Prev. Vet. Med. 103: 287-297.

Van Knegsel, A. T. M., Remmelink, G. J., Jorjong, S., Fievez, V., Kemp,B., 2014. Effect of dry period length and dietary energy source on energy balance, milk yield, and milk composition of dairy cows. J. Dairy Sci. 97: 1499-1512.

Vassilev, T. L., Veleva, K. V., 1996. Natural polyreactive IgA and IgM autoantibodies in human colostrum. Scand. J. Immunol. 44: 535-539.

Verweij, J. J., Koets, A. P., Eisenberg, S. W. F., 2014. Effect of continuous milking on immunoglobulin concentrations in bovine colostrum. Vet. Immunol. Immunophatol. 160: 225-229.

Vollmers, H. P., Brändlein, S., 2009. Natural antibodies and cancer. New Biotech. 25: 294298. 
Wardemann. H., Nussenzweig, M. C., 2007. B-cell self tolerance in humans. Adv. Immunol. 95: 83-109. 
CHAPTER 7

General discussion 


\subsection{Introduction}

In early lactation, dairy cows experience a negative energy balance (NEB) caused by a sudden increase of energy requirement for milk production while the dietary energy intake is limited. The NEB has been related to an increased occurrence of metabolic disorders (Grummer, 1993), infectious diseases (Collard et al., 2000), reduction in fertility (Butler, 2003), inflammation (Bionaz et al., 2007, Trevisi et al., 2012), immunosuppression (Mallard et al., 1998) and oxidative stress (Sordillo et al., 2009). Cows with NEB and elevated plasma free fatty acid (FFA) and $\beta$-hydroxybutyrate (BHB) concentrations have a higher occurrence of clinical problems (Ospina et al., 2010b, Chapinal et al., 2011, Seifi et al., 2011) and reduced fertility (Walsh et al., 2007, Ospina et al., 2010a). Extensive research efforts have been made to find ways to reduce the health problems in early lactation by improving the energy balance (EB) in dairy cows (as reviewed by Ingvartsen and Moyes, 2013, Van Knegsel et al., 2014a).

Recently, there has been an interest in shortening the dry period as a strategy to improve EB in early lactation of high yielding dairy cows. Shortening or omitting the dry period shifts milk yield partially from postcalving to precalving period and, herewith, improves EB (Rastani et al., 2005, Van Knegsel et al., 2014b) and metabolic status in early lactation (Andersen et al., 2005, de Feu et al., 2009). In addition, shortening or omitting the dry period also improved fertility by reducing the interval from calving to first ovulation postpartum (Gümen et al., 2005, de Feu et al., 2009, Chen et al., 2015b). Meta-analysis showed that a short dry period tended to reduce the risk of ketosis (odd ratio $=0.75 ; P=0.09$ ) but did not affect occurrence of clinical mastitis, retained placenta or displaced abomasum compared with a conventional dry period (Van Knegsel et al., 2013). Studies on consequences for disease incidence of omitting the dry period are rare and often limited on animal numbers, but studies of Rastani et al. (2005) and Schlamberger et al. (2010) showed no effect of omitting the dry period on diseases incidence (clinical mastitis, retained placenta, ketosis and lameness) compared with a conventional dry period. It can be hypothesized that if shortening or omitting the dry period improves the EB of cows in early lactation, this will also improve health and fertility of dairy cows with a short or no dry period, compared with cows with a conventional dry period. The main objective of this thesis was to investigate effects of dry period length and dietary energy source on health status related variables in dairy cows and their calves. 


\subsection{Biomarkers for Health in Dairy Cows}

Animal health is an important factor for productive life time in dairy cows (Booth et al., 2004, Carlén et al., 2004). A clinical health problem can be determined by clinical examinations combined with various diagnostic tests (Petersen et al., 2004). Measuring health status through various diagnostic tests is essential to generate an important research tool when studying pathogenesis and inflammatory processes. In the present study, we refer to health problems as clinical health problems related to inflammation, such as clinical mastitis, metritis, retained placenta and fever. Subclinical disease as a response of inflammatory processes but impact on animal health may remain undetected and may be indirectly reflected by impaired growth and fertility (Petersen et al., 2004). Identification of biomarkers for various clinical and subclinical diseases would be useful to assess early diagnosis, treatment, and prevention of important diseases (Petersen et al., 2004). A biomarker is defined as a biological characteristic that can be objectively measured as an indicator of normal biological processes or a response to environmental intervention (Van Altena, 2016). In this thesis, potential biomarkers are associated with health status in dairy cows such as acute phase proteins (APP), liver functionality variables (Bionaz et al., 2007, Bertoni et al., 2008), oxidative stress (Bernabucci et al., 2005) and natural antibodies (NAb) (Van Knegsel et al., 2007a, Ploegaert et al., 2010) are used. In this thesis, we refer to those potential biomarkers as health variables.

In human and veterinary medicine, levels of APP in plasma have been used as a biomarker for infection and inflammation. As quantitative biomarkers for infection, APP can be used in diagnosis, prognosis and in monitoring response to general health screening in dairy cows (Petersen et al., 2004, Gruys et al., 2005, Eckersall and Bell, 2010). During NEB and inflammation, pro-inflammatory cytokines stimulated hepatic synthesis of positive APP, such as haptoglobin and ceruloplasmin, and impaired hepatic synthesis of negative APP such as albumin and cholesterol (Bionaz et al., 2007, LeBlanc, 2012). Bilirubin and paraoxonase are commonly used as biomarkers for liver status around calving (Bionaz et al., 2007, Bertoni et al., 2008). High bilirubin and low paraoxonase levels have been associated with liver damage (Bionaz et al., 2007, Bertoni et al., 2008). Reactive metabolites oxygen (ROM) and ferric reducing antioxidant power (FRAP) are known as oxidative stress variables. Ferric reducing antioxidant power is an indicator of antioxidant status (Jacometo et al., 2015, Konvičná et al., 2015), and acts to neutralize the production of reactive intermediates (e.g. ROM) caused by oxidative stress in early lactation (Esposito et al., 2014). Creatinine is a marker for 
mobilization of body protein. Serum NAb levels have been suggested as biomarkers for general disease resistance in dairy cows (Van Altena, 2016). Natural antibodies have an important function to provide not only the first line of defence but also to maintain homeostasis, to promote phagocytes of dead cells, and to prevent infectious and autoimmune diseases (Cojocaru et al., 2009). The level of antibodies in plasma is highly related to disease resistance with respect to infections and metabolic disorders (Baumgarth et al., 2005).

\subsection{Effect of Shortening or Omitting the Dry Period on Health Variables}

This paragraph discusses the effects of dry period length on inflammatory biomarkers (positive and negative APP), liver functionality (paraoxonase and bilirubin), oxidative stress (ROM and FRAP), NAb, NAAb and creatinine over 2 subsequent lactations.

\subsubsection{Effect of Dry Period Length on Inflammatory Biomarkers}

Omitting the dry period increased positive APP levels (ceruloplasmin and haptoglobin) and negative APP (cholesterol) levels in plasma in the first subsequent lactation after implementation of dry period length treatments (Chapter 2). In the second subsequent lactation after implementation of dry period length treatments, omitting the dry period resulted in higher ceruloplasmin levels in plasma but did not affect plasma cholesterol levels compared with a dry period of $30-\mathrm{d}$ or $60-\mathrm{d}$. In the second subsequent lactation after implementation of dry period length, cows which were planned for 0 -d but dried themselves off $(0 \rightarrow 30-d)$ had a lower plasma ceruloplasmin levels compared with cows with a 0-d dry period (Chapter 3). This finding is partly unexpected. It was hypothesized that if EB and metabolic status are improved, due to omitting or shortening of the dry period, this will reduce the inflammatory status (i.e. higher levels of negative APP, and lower levels of positive APP) during the transition period. Previous studies showed that in early lactation cows with a better EB and improved metabolic status had increased negative APP in plasma like cholesterol (Kaneene et al., 1997, Trevisi et al., 2009). It can be suggested that the increased cholesterol levels in plasma in the first subsequent lactation after implementation of dry period length in the present study is not only related to better EB in cows with a 0-d dry period but also because of the differences in energy intake and ration composition. Earlier, ceruloplasmin and haptoglobin were negatively related to EB (Bionaz et al., 2007). In the current study, however, the improved EB in cows with 0-d dry period did not result in lower ceruloplasmin or haptoglobin levels in plasma, compared with cows 
with a 60-d dry period. In addition, ceruloplasmin and haptoglobin levels in plasma were positively related to occurrence of clinical health problems. Also in earlier studies, the increased levels of ceruloplasmin and haptoglobin were associated with health problems of cows in early lactation (Conner et al., 1988, Chassagne et al., 1998, Sheldon et al., 2001). It appears that, besides dry period length and EB, also the occurrence of clinical health problems might cause increased levels of haptoglobin and ceruloplasmin in plasma of dairy cows in early lactation.

\subsubsection{Effect of Dry Period Length on Liver Functionality}

Chapter 2 described that in the first subsequent lactation after implementation of dry period length treatments, omitting the dry period improved the EB and reduced bilirubin levels in plasma which was in line with expectations. The reduced bilirubin levels in plasma in cows with a 0-d dry period means that these cows have better liver function compared with cows with a 60-d dry period, which is related to the better EB and reduced milk yield in these cows. It was hypothesized that if EB is improved, due to omitting the dry period, bilirubin levels in plasma will reduce as well. Plasma bilirubin levels were positively correlated with the degree of fat infiltration of the liver which is caused by the accumulation of triacylglycerol (TAG) in the liver (West, 1990). Also in the current experiment, cows with a 0-d dry period had a lower plasma FFA and liver TAG concentration, compared with cows with a 30-d or 60-d dry period (Chen et al., 2015a). The lower liver TAG concentration was in line with reduced plasma bilirubin concentration in cows with a $0-d$ dry period. In the second lactation after implementation of dry period length treatments, plasma bilirubin levels were not different among cows with different dry period lengths (Chapter 3). However, cows which were planned for a 0 -d dry period but dried themselves off $(0 \rightarrow 30-d)$ had a higher plasma bilirubin levels compared with cows with a $0-d, 30-d$ or $60-\mathrm{d}$ dry period. The increased bilirubin in cows with $0 \rightarrow 30$-d dry period suggests that these cows have worse liver function compared with cows with a $0-d, 30-d$, or 60-d dry period, which was explained by the more severe NEB in these cows. Reduced bilirubin levels indicated better clearance of secretory enzymes in the liver as response to liver cell damage and have been associated with a better EB (Assenat et al., 2004, Bertoni et al., 2008). Chen et al. (2016) reported for this experiment that in the second subsequent lactation, cows which were planned for 0 -d but dried themselves off $(0 \rightarrow 30-d)$ had severe NEB compared with cows with a 0 -d or 30-d dry period. Moreover, in the second subsequent lactation, omitting the dry period 
resulted in a less pronounced improvement of $\mathrm{EB}$ and metabolic status in early lactation compared with the first subsequent lactation after implementation of dry period length treatments (Chen et al., 2016).

It can be hypothesized that if EB improves and bilirubin in plasma reduces by omitting the dry period, the levels of paraoxonase in plasma will increase in cows with a 0 -d dry period. Paraoxonase is known as a liver protein with hydrolase activity and may serve as an index of liver function because it is drastically reduced in chronic liver damage (Bionaz et al., 2007) or during lipid metabolic disorders (Ferré et al., 2002, Aviram and Rosenblat, 2004, Turk et al., 2004). As mentioned before, cows with a 0-d dry period had better liver functionality which was indicated by reduced TAG in liver and plasma bilirubin levels, however, but not with respect to paraoxonase. In Chapter 2, paraoxonase was negatively associated with haptoglobin and ROM which could be related to a more severe inflammatory condition or due to oxidative stress. Paraxonase is also known as an antiinflammatory variable (James and Deakin, 2004) and as an important anti-oxidant variable (Bell et al., 2010). Thus, we suggest in that case the reduced paraoxonase levels in plasma could not be explained by liver status but might be explained by inflammation or oxidative stress.

\subsubsection{Effect of Dry Period Length on Oxidative Stress}

Omitting the dry period resulted in increased oxidative stress (increased ROM levels in plasma) over 2 subsequent lactations which was not related to the better EB and improved metabolic status in these cows (Chapter 2 and 3). High ROM levels in plasma were earlier associated with severe NEB indicated by increased BHB and FFA concentrations (Bernabucci et al., 2005, Pedernera et al., 2010). In early lactation, cows with a 0 -d dry period produced less milk yield, resulting in lower metabolic demand and lower oxygen requirement compared with cows with a 60-d dry period. Accumulation of reactive oxygen species can be prevented by reduced oxygen requirement for metabolic processes (Spears and Weiss, 2008) and increased the availability of antioxidant defence systems such as FRAP (Abuelo et al., 2015). In the current study, there was no effect of dry period length on FRAP levels in plasma. Together with low paraoxonase levels in plasma in cows with a 0 -d dry period, availability of antioxidant FRAP and paraoxonase levels in plasma is not sufficient to prevent oxidative stress in these cows. It is suggested that high ROM levels in plasma in cows with a 0 -d dry period could be 
explained by the occurrence of health problems related to inflammation, rather than directly explained by the (better) EB in these cows.

\subsubsection{Effect of Dry Period Length on Natural Antibodies}

Increased incidences of infectious diseases in cows with NEB have been attributed to suboptimal immune function in early lactation (Mallard et al., 1998). In the present study (Chapter 4), cows with a 0-d dry period not only had improved EB in early lactation but also higher somatic cell count (SCC), higher $\mathrm{NAb}$ titers for isotypes IgG and IgM binding keyhole limpet hemocyanin (KLH) and lipopolysaccharides (LPS) in milk, and higher titer of IgG binding LPS in plasma compared with cows with a $30-\mathrm{d}$ or $60-\mathrm{d}$ dry period in the first lactation after implementation of dry period length treatments. In addition, cows with 0 -d dry period had higher IgG natural autoantibodies (NAAb) binding myosin (MYO) in plasma compared with cows with a 60-d dry period (Table 7.1). In the second lactation after implementation of a short or no dry period, the effects of omitting the dry period on NAb titers binding KLH and LPS in plasma and milk and NAAb binding MYO in plasma disappeared. Natural antibodies act as a first line of defence against infection (Ochsenbein et al., 1999, Zinkernagel, 2012) but also to maintain homeostasis, to promote phagocytes of dead cells, and to prevent infectious and autoimmune diseases (Cojocaru et al., 2009). In an earlier study, high NAAb binding MYO in milk of cows were associated with severe NEB $(\beta=-0.001, P<$ $0.10)$, low dry matter intake (DMI) $(\beta=-0.049, P<0.05)$ and occurrence of clinical mastitis (Van Knegsel et al., 2012). In the study of Van Knegsel et al. (2012), NAAb binding MYO was measured in milk, but not in plasma. Measuring antibodies in milk compared with plasma is easier but may give different results due to low phenotypic correlation between NAbs in blood and NAbs in milk.

In the second lactation after implementation dry period length treatments, cows with a 0-d dry period compared with cows with a 30-d dry period have a lower NAAb IgM binding carbonic anhydrase (CA; enzyme that involve in the regulation of $\mathrm{pH}$ during inflammation), but not compared with cows with a $60-\mathrm{d}$ dry period (Table 7.1). This is may be related to the fact that in the second subsequent lactation, omitting the dry period resulted in a less pronounced improvement of EB and metabolic status in early lactation compared with the first subsequent lactation after implementation of dry period length treatments (Chen et al., 2016). Carbonic anhydrase have functions in regulation of $\mathrm{pH}$ and fluid balance (Badger and Price, 1994) as observed during inflammation (Mihaylova et al., 
2008). However, NAAb binding CA in plasma is associated with SCC (Figure 7.2). It is suggested that the higher NAb titers in plasma and in milk for cows with a $0-\mathrm{d}$ dry period in first and second lactations after implementation of dry period length treatments are related with the improved EB and reduced milk yield in these cows (Chapter 4). It might be speculated that NAAb binding CA in plasma reflects a subclinical udder infection in cows with a 0 -d dry period.

\subsubsection{Effect of Dry Period Length on Creatinine}

In the first lactation after implementation dry period length treatments, dry period length affected creatinine levels dependent on parity. Cows with parity $\geq 3$ had higher levels of creatinine in plasma when had a 0-d dry period compared with cows with parity 2 (Chapter 2). In the second subsequent lactation after implementation dry period length treatments, creatinine did not different among dry period length treatments. However, cows which were planned for a 0-d dry period but dried themselves off $(0 \rightarrow 30-d)$ had higher plasma creatinine levels compared with cows with a 60-d dry period (Chapter 3), which was possibly related to the lower EB in these cows. In the first subsequent lactation of the current experiment, during the first 2 weeks after calving cows with parity $\geq 3$ cows showed less reduction in milk yield when the dry period was omitted compared with cows with parity 2 . Creatinine typically decreases around calving due to milk production (Kokkonen et al., 2005). Previous studies from Annen et al. (2004) and Santschi et al. (2011) showed a reduction in milk yield after shortening or omitting the dry period for cows with parity 2 , but not for cows with parity $>3$. Thus, it suggests that the increased creatinine levels in plasma of cows with a 0-d dry period in the first subsequent lactation could be explained by parity. In the current experiment, cows which were planned for a 0-d dry period but dried themselves off $(0 \rightarrow 30-d)$ not only had severe NEB but also had high precalving BCS (Chen et al., 2016). Cows with severe NEB, also have the more severe mobilization of muscle (Graugnard et al., 2012). Previous study from Pires et al. (2013) showed cows with high BCS group had higher plasma creatinine and severe NEB compared with cows with low BCS. Thus, this study suggested that the increased plasma creatinine levels in cows which were planned for a 0 -d dry period but dried themselves off $(0 \rightarrow 30-d)$ was related to high precalving BCS and a more severe NEB in these cows. 


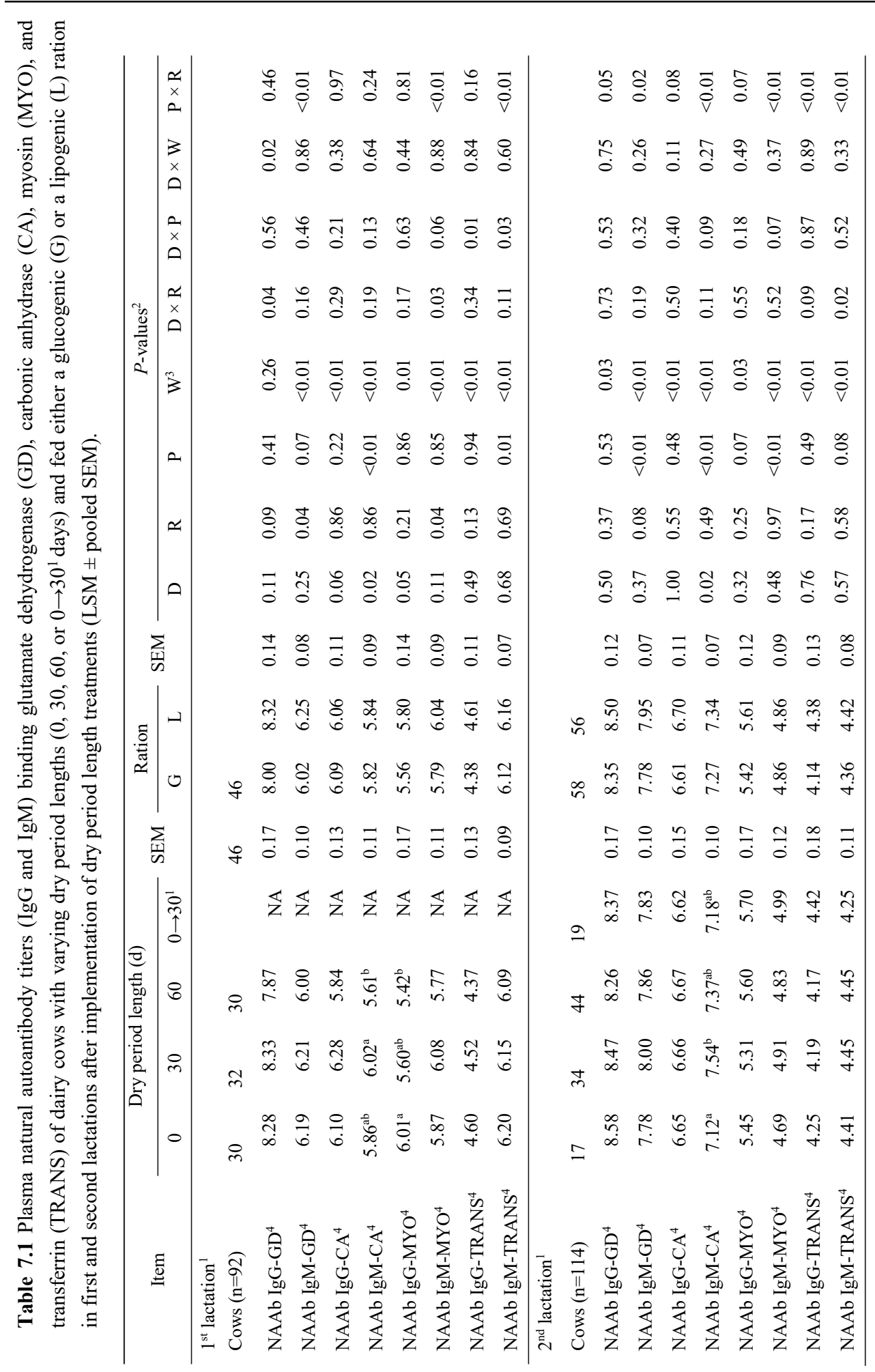




\title{
Table 7.1 continued
}

\begin{abstract}
${ }^{\mathrm{a}, \mathrm{b}}$ Values within dry period length in the same row with different superscripts differ $(P<0.05) .{ }^{1}$ In the first and second lactation after implementation of dry period length and dietary treatments; in the second lactation, 19 cows which were planned to have a 0 -d dry period, had a milk production of $<4 \mathrm{~kg} / \mathrm{d}$ for at least $30 \mathrm{~d}$ before the expected calving date and were allowed to go dry; ${ }^{2} \mathrm{D}=$ dry period; $\mathrm{R}=$ ration; $\mathrm{P}=$ parity; ${ }^{3}$ Weeks $-3,-2, \ldots, 9$ relative to calving; ${ }^{4}$ NAAb titers is $\log 2$ values of the dilutions that gave an extinction closest to 50 percent of Emax where Emax represents the highest mean extinction of a standard positive (pooled) serum present on each microtiter plate (Ploegaert et al., 2007). Antibody names are combination of natural autoantibody (NAAb), antigen abbreviation (GD, CA, MYO or TRANS) and immunoglobulin isotype (IgG or IgM).
\end{abstract}

\subsection{Effect of Dietary Energy Source on Health Variables in Dairy Cows}

Feeding a glucogenic or lipogenic ration did not affect occurrence of health problems in dairy cows in early lactation in both lactations in the present experiment. In the first lactation after implementation of dry period and dietary treatments, feeding a glucogenic or lipogenic ration affect negative APP and NAb, dependent on parity. In the first lactation after implementation of dry period and dietary treatments, cows with parity 2 and fed a glucogenic ration had higher NAb titer in plasma and milk (Chapter 4) compared with cows with parity 2 and fed a lipogenic ration. Moreover, cows with parity $>3$ and fed a glucogenic ration had higher cholesterol levels (Chapter 2) compared with cows with parity $>3$ and fed a lipogenic ration. In an earlier study, a glucogenic ration reduced milk energy output and herewith improved the EB of dairy cows in early lactation, compared with a lipogenic ration (Van Knegsel et al., 2007b), which was related to higher titers of NAb binding KLH in plasma. Also in the current experiment, feeding a glucogenic ration in early lactation improved EB by a reduction in milk energy output, realised by a reduction in milk fat content, compared with a lipogenic ration (Van Knegsel et al., 2014b). Moreover, this improvement in EB was also associated with an improved metabolic status (e.g. reduced plasma FFA and BHB concentrations), independent of dry period length (Chen et al., 2015a). Severe NEB has been associated with inflammation as indicated by increased haptoglobin and reduced cholesterol (Bionaz et al., 2007, Trevisi et al., 2012). Thus, it could be expected that when feeding a glucogenic ration improves the EB in early lactation it also reduces inflammation and increases NAb titers in plasma. In the second lactation after implementation of dry period length and dietary treatments, ration had more effect on health variables, compared with the first lactation. In the second lactation after implementation of dry period length treatments, cows fed a lipogenic ration had higher plasma cholesterol level in plasma compared with cows fed a glucogenic ration, independent of dry period length (Chapter 3). In addition, cows 
with a 0-d dry period and fed a lipogenic ration had higher FRAP and creatinine levels in plasma compared with cows with a 0-d dry period and fed a glucogenic ration (Chapter 3). In the second lactation after implementation of the dry period length treatments, Chen et al. (2016) reported for the current experiment that a glucogenic ration compared with a lipogenic ration resulted in lower plasma FFA and BHB concentrations. Reduced plasma FFA and BHB concentrations have been associated with increased cholesterol (Bionaz et al., 2007, Trevisi et al., 2012) but not related to plasma FRAP (Wullepit et al., 2012) or creatinine (Bionaz et al., 2007). However, no ration effect on FRAP in the study of Wullepit et al. (2012) and no dietary treatment in the study of Bionaz et al. (2007) and Trevisi et al. (2012). Earlier, cholesterol levels were influenced by fat supplementation (Carroll et al., 1990). Thus, it might be speculated that the high cholesterol levels in the second lactation is related to the high fat content in lipogenic ration, compared with a more glucogenic ration. 


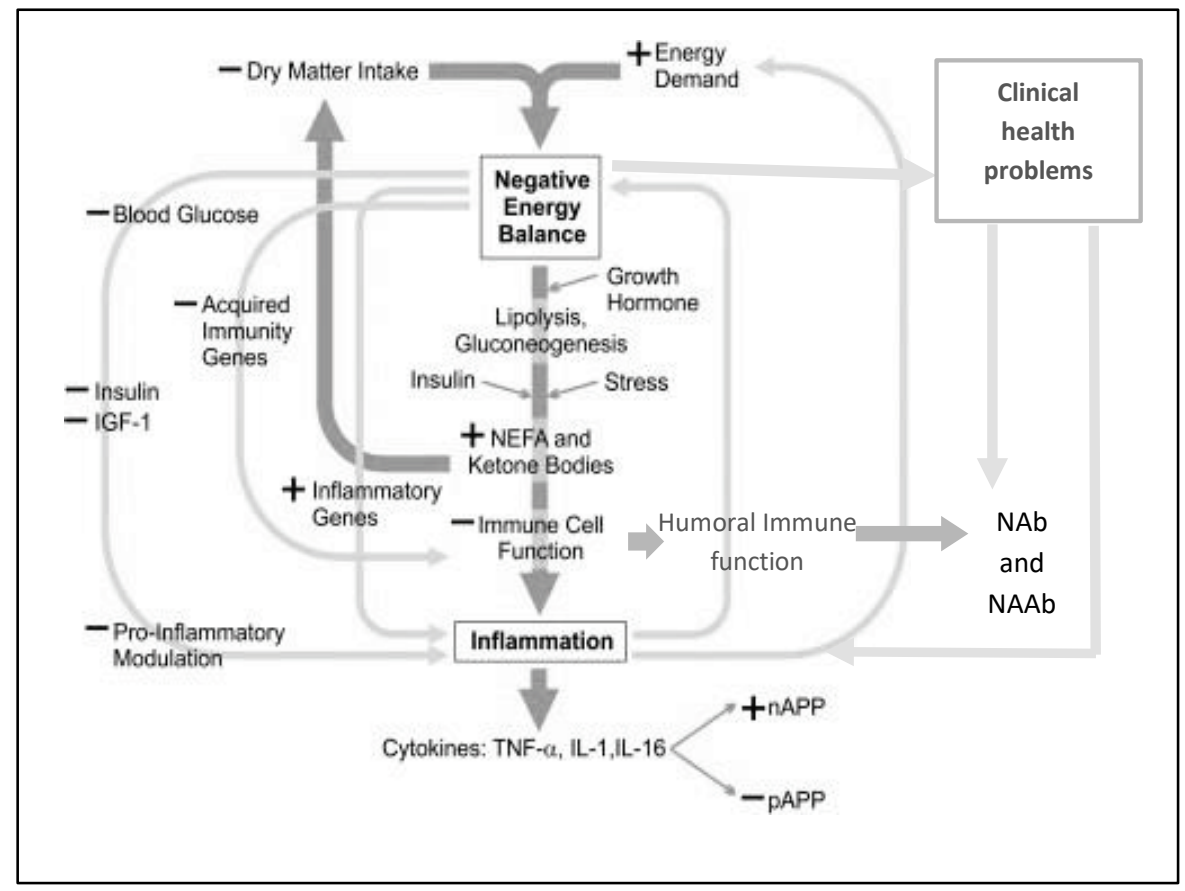

Figure 7.1 Interaction among immunity, endocrinology, metabolism, and clinical health problems in dairy cows during the transition period (adapted from Esposito et al., 2014).

\subsection{Interaction among Immunity, Endocrinology, Metabolism and Clinical Health Problems in Dairy Cows. \\ Inflammation and dysregulated immune function have been associated with} NEB and metabolic disorders in dairy cows in early lactation (Esposito et al., 2014). Figure 7.1 illustrates that NEB in dairy cows in early lactation is not only related to metabolic disorders and inflammation but also to immunosuppression and occurrence of clinical health problems. During NEB, many metabolic hormones such as insulin, growth hormone and their receptor changes as a response to physiological needs in this period (Goff and Horst, 1997). During NEB, the growth hormone-IGF axis uncouples due to a down-regulation of liver growth hormone receptor which is associated with a reduction of insulin concentration (Butler, 2003). Low insulin concentration also increase mobilization of triacylglycerol (TAG) deposits as FFA and ketone bodies (Grummer, 1993). High FFA and ketone 
bodies in plasma during severe NEB increase the risk for fatty liver and ketosis (Grummer, 1993), dysfunctional immune cells (Mallard et al., 1998, Lacetera et al., 2005) and increase pro-inflammatory cytokines (Bionaz et al., 2007, Trevisi et al., 2012). Pro-inflammatory cytokines such as TNF- $\alpha$, IL-1 and IL-6 regulate APP concentration in plasma (Baumann and Gauldie, 1994). The liver plays a central role in these changes, as the hepatic synthesis of many proteins increase (positive APP) whiles the synthesis of other proteins decrease (negative APP). Cows with severe NEB as indicated by high FFA and ketone bodies concentrations in plasma have been related to the occurrence of health problems related to inflammation such as clinical mastitis (Mallard et al., 1998, Sordillo et al., 2009), metritis and retained placenta (Enevoldsen and Sørensen, 1992, Butler, 2003, Bertoni et al., 2009). Negative energy balance has been associated with level of humoral innate immunity such as low NAb in plasma (Van Knegsel et al., 2007a) (Chapter 4) and low IgM antibodies (Lacetera et al., 2005). Cows with NEB and uterine infection had higher haptoglobin, lower albumin and lower paraoxonase in plasma (Schneider et al., 2013) (Chapter 3). Cows with clinical mastitis had higher levels of haptoglobin in plasma (Pyörälä, 2003) and lower titers of NAb binding KLH in plasma (Ploegaert et al., 2010, Thompson-Crispi et al., 2013) (Chapter 4), compared with healthy cows. Clinical health problems related to inflammation might be reflected by the changes in inflammatory biomarkers (Chapter 2 and 3) and titers of NAb (Chapter 4).

\subsection{What Explains (Lack of) Effects of Dry Period Length and Dietary Treatments on Health in Dairy Cows}

The current study shows that omitting the dry period not only improves EB and metabolic status but also influences health variables such as increased levels of positive APP, increased levels of negative APP, reduced levels of bilirubin, increased oxidative stress, increased $\mathrm{NAb}$ levels in plasma and milk. It was hypothesized that an improvement of the EB due to shortening or omitting the dry period would be beneficial for health of the dairy cows, the changes of health variables due to dry period length treatments could not be completely explained by the effects of dry period on the EB. It can be questioned whether the changes of health variables in the current experiment was directly due to dry period length effects, ration effects or indirectly through effect of dry period length on differences in EB, mammary health, clinical health problems, body condition, or uterine health of cows. 


\subsubsection{Effect of Energy Balance on Health Variables in Dairy Cows}

As mentioned previously, omitting the dry period improved EB (Rastani et al., 2005, Van Knegsel et al., 2014a) and metabolic status in early lactation (Andersen et al., 2005, de Feu et al., 2009, Chen et al., 2015a) compared with a conventional dry period. A better EB is only related to low plasma bilirubin levels but is not related to APP, oxidative stress, creatinine and NAb (Chapter 2 and 3). Milk yield is positively related to the levels of bilirubin. Dry matter intake is negatively related to levels of bilirubin. Since the combination of both milk yield and DMI results in EB, it can be suggested that the effect of dry period length on bilirubin levels was associated with alterations in EB and metabolic status. In the present experiment, cows with NEB had increased plasma concentrations of FFA and bilirubin. This finding is expected because the FFA concentration was positively related to the levels of bilirubin in plasma (Qualmann et al., 1997). Variations of FFA and bilirubin concentrations over time were the most pronounced in the first 2 weeks after calving, compared with the period of week 1 to 9 postcalving. In the present experiment, FFA and bilirubin concentrations in plasma were reduced after the first 2 weeks after calving which may indicate better metabolic status and liver functionality after week 2 in lactation. Thus, EB explains effect of dry period length on bilirubin.

\subsubsection{Effect of Mammary Health on Health Variables on Dairy Cows}

In the present experiment, effect of dry period length on inflammatory biomarkers and oxidative stress variables in plasma could partly be explained by clinical mastitis. In addition, effect of dry period length on NAb titers in plasma and milk could partly be explained by both the high SCC $(\geq 250,000$ cell $/ \mathrm{mL})$ and clinical mastitis. In the current experiment, omitting the dry period increased SCC in milk in the subsequent lactation, but did not affect the occurrence of clinical mastitis compared with shortening or conventional dry period both in the first and second lactations (Chapter 4). The increased SCC in milk was related to decreased titer of IgG binding LPS in plasma (Chapter 4). In the current study, SCC did not relate to inflammatory biomarkers and oxidative stress (Chapter 2 and 3). Clinical mastitis was associated with decreased IgG binding LPS titers in plasma (Chapter 4), increased ceruloplasmin and ROM levels in plasma, but not related to other health variables (Table 7.2). Earlier, clinical mastitis has been associated with decreased IgM binding KLH titers in plasma (Thompson-Crispi et al., 2013), increased plasma haptoglobin levels (Pyörälä, 2003), increased bilirubin levels 
(Minuti et al., 2015) and decreased plasma paraoxonase levels (Turk et al., 2012). It was suggested that the level of NAb in plasma or milk may be an additional variable to select for clinical mastitis resistance in dairy cows (Ploegaert et al., 2010, Thompson-Crispi et al., 2013). The increased NAb levels in milk were associated with an increased SCC and clinical mastitis occurrence, which is in line with earlier work (Ploegaert et al., 2010). However, the mechanism underlying the relationship between high NAb in plasma with a decreased clinical mastitis occurrence remains to be elucidated. Results of the current experiment indicate that IgM-binding KLH in plasma can be an early predictor of clinical mastitis occurrence in dairy cows. Further studies are required to evaluate factors that predict mammary health after a shortened or omitted dry period in dairy cows.

\subsubsection{Effect of Clinical Health Problems on Health Variables in Dairy Cows}

In Chapter 2, 3 and 4, we reported that higher NAb titers, higher ceruloplasmin, higher haptoglobin, lower albumin and higher ROM in plasma were related to the occurrence of clinical health problems. It is known that the occurrence of clinical health problems is associated with severe or prolonged inflammation (Trevisi et al., 2011) and oxidative stress (Trevisi et al., 2010) around calving. Changes in inflammatory biomarkers and oxidative stress after calving of cows with different dry period lengths were related to the occurrence of health problems in the present experiment, but maybe many of these initiate around calving and several remained subclinical (Petersen et al., 2004, Trevisi et al., 2011). Clinical health problems is a very general term, and specific diseases (metabolic or infectious diseases) might have different effects on variables relation to inflammation or oxidative stress (Bertoni et al., 2009, Sordillo and Aitken, 2009). From this perspective, we suggest that the dry period length may not directly be a causative factor for inflammation and oxidative stress around calving. Moreover, severe NEB could indirectly be a risk factor for inflammation diseases (e.g. clinical mastitis and endometritis).

\subsubsection{Effect of Body Condition on Health Variables in Dairy Cows}

In the present study, higher precalving BCS was related to higher creatinine in plasma of dairy cows from week 3 before calving until 4 weeks after calving. No relationship between precalving BCS with plasma APP, liver functionality variables, oxidative stress and NAb levels in plasma in dairy cows was present in the current study. Our finding indicated that precalving BCS in the second lactation 
after repeated implementation of dry period length treatments may be a risk factor for severe NEB and metabolic disorders which is in line with earlier study (Bernabucci et al., 2005) but BCS was not related to inflammatory or oxidative stress variables.

\subsubsection{Effect of Uterine Health on Health Variables in Dairy Cows}

A severe NEB in early lactation has been related with a greater risk for metritis or endometritis (Butler, 2003). Cows with endometritis have an increased culling rate and impaired fertility among others by reduced pregnancy rates (LeBlanc et al., 2002). Uterus palpation and monitoring of vaginal discharge (VD) has been widely used to diagnose clinical endometritis in dairy cows (LeBlanc et al., 2002, Gilbert et al., 2005, Williams et al., 2005, Prunner et al., 2014). Vaginal discharge has been related to high levels of haptoglobin in plasma (Huzzey et al., 2009, Dubuc et al., 2010, Ametaj et al., 2014). In the second lactation, uterine health status (UHS) was monitored by scoring VD based on a 4-point scoring system $(0,1,2$ or 3$)$ in week 2 and 3 after calving. Cows were classified as having a healthy uterine environment (HU, VDS $=0$ or 1 in both week 2 and 3), nonrecovering uterine environment (NRU, VDS $=2$ or 3 in week 3 ) or a recovering uterine environment (RU, VDS $=2$ or 3 in week 2 and VDS $=0$ or 1 in week 3 ). In Chapter 3, we reported that cows with NRU had higher levels of haptogloblin and lower paraoxonase in plasma compared with cows with HU. Cows with a NRU had lower levels of albumin compared with cows with RU. Schneider et al. (2013) reported that cows with infection in the uterus had lower levels of albumin, lower paraoxonase and higher haptoglobin in plasma compared with cows with a healthy uterus. In the present experiment, uterine health status of the cows was not related to NAb, NAAb, cholesterol, albumin, bilirubin, FRAP and creatinine in plasma. These results indicate that the increase in levels of +APP and oxidative stress variables in cows with a 0 -d dry period in the first and second lactation after implementation of dry period length treatments might be explained by uterine health status as one of clinical health problems related to inflammation but not EB.

\subsection{The Relationships between Health Variables and DPL, EB, SCC, Clinical Mastitis, Clinical Health Problem, BCS, or UHS}

Table 7.2 shows an overview about the relationships between health variables (NAb, inflammatory biomarkers and oxidative stress) and DPL, EB, SCC, clinical mastitis $(\mathrm{CM})$, clinical health problems (CHP), precalving BCS, or UHS in 
the first 2 weeks after calving in the first and second lactation after implementation dry period treatments. Dry period length influenced levels of IgG binding LPS or MYO, IgM binding CA, ceruloplasmin, cholesterol, bilirubin, paraoxonase, ROM and creatinine. When including EB, SCC, clinical mastitis, CHP, BCS, or UHS as covariate in the model for each analysis, some health variables were associated with the covariate in the first 2 weeks after calving. 
Table 7.2 Relationship between health variables (natural (auto) antibodies, inflammatory biomarkers and oxidative stress) and dry period length (DPL), energy balance (EB), somatic cell count (SCC), clinical mastitis (CM), clinical health problem (CHP), body condition score (BCS), or uterine health status (UHS) in the first 2 weeks after calving.

\begin{tabular}{|c|c|c|c|c|c|c|c|}
\hline \multirow[t]{2}{*}{ Variables } & \multicolumn{7}{|c|}{$\begin{array}{c}\text { Values }(1,2) \text { indicate an effect in lactation } 1 \text {, lactation } 2 \text { or } \\
\text { both }^{\text {a, b }}\end{array}$} \\
\hline & DPL & EB & SCC & $\mathrm{CM}$ & CHP & BCS & UHS \\
\hline \multicolumn{8}{|l|}{ Natural antibodies ${ }^{\mathrm{c}}$} \\
\hline IgG binding KLH & - & - & 2 & - & - & - & - \\
\hline IgM binding KLH & - & - & - & - & - & - & - \\
\hline IgG binding LPS & 1 & 2 & - & - & 1 & - & - \\
\hline IgM binding LPS & - & - & 2 & - & 2 & - & - \\
\hline IgG binding GD & - & 2 & - & - & - & - & - \\
\hline IgM binding GD & - & - & - & - & - & - & - \\
\hline IgG binding CA & - & - & - & - & - & - & - \\
\hline IgM binding CA & 1,2 & 2 & 2 & - & - & - & - \\
\hline IgG binding MYO & 1 & - & 2 & - & - & - & - \\
\hline IgM binding MYO & - & - & 2 & 2 & 2 & - & - \\
\hline IgG binding TRANS & - & 2 & 2 & - & - & - & - \\
\hline IgM binding TRANS & - & - & 2 & - & - & - & - \\
\hline \multicolumn{8}{|l|}{ Acute phase protein } \\
\hline Haptoglobin (g/L) & - & - & - & - & 2 & - & 2 \\
\hline $\begin{array}{l}\text { Ceruloplasmin } \\
(\mu \mathrm{mol} / \mathrm{L})\end{array}$ & 1,2 & - & - & 1 & 1 & - & - \\
\hline Albumin $(\mathrm{g} / \mathrm{L})$ & - & - & - & - & 1 & - & 2 \\
\hline $\begin{array}{l}\text { Cholesterol } \\
(\mathrm{mmol} / \mathrm{L})\end{array}$ & 1 & - & - & - & - & - & - \\
\hline \multicolumn{8}{|l|}{ Liver function } \\
\hline$\overline{\text { Bilirubin }(\mu \mathrm{mol} / \mathrm{L})}$ & 1,2 & 1,2 & - & - & 1 & - & - \\
\hline Paraoxonase, $\mathrm{U} / \mathrm{mL}$ & 1 & - & - & - & 2 & - & 2 \\
\hline \multicolumn{8}{|l|}{ Oxidative stress } \\
\hline $\begin{array}{l}\mathrm{ROM}^{\mathrm{d}} \\
\left(\mathrm{mg} \mathrm{H}_{2} \mathrm{O}_{2} / 100 \mathrm{~mL}\right)\end{array}$ & 1,2 & - & - & 1 & 1 & - & - \\
\hline $\mathrm{FRAP}^{\mathrm{d}}(\mu \mathrm{mol} / \mathrm{L})$ & - & - & - & - & - & - & - \\
\hline Creatinine $(\mu \mathrm{mol} / \mathrm{L})$ & 2 & - & - & - & - & 2 & 2 \\
\hline
\end{tabular}

${ }^{\mathrm{a}} \mathrm{EB}=$ Energy balance; $\mathrm{SCC}=$ Somatic cell count; $\mathrm{CM}=$ Clinical mastitis; $\mathrm{CHP}=$ Clinical health problem; $\mathrm{BCS}=$ Body condition score; UHS = Uterine health status; ${ }^{\mathrm{b}} \mathrm{EB}, \mathrm{SCC}, \mathrm{CHP}$ (clinical mastitis, metritis, retained placenta and fever), and $\mathrm{CM}$ are in the first 2 weeks after calving in the first and second lactations; BCS ( $<3.75$ vs. $\geq 3.75$ ) is in the last month before calving in the second lactation; UHS in the second lactation categorized as 1) Healthy uterine environment (HU): vaginal discharge score (VDS) $=0$ or 1 in both week 2 and 3; Recovering uterine environment (RU): VDS $=2$ or 3 in week 2 and VDS $=0$ or 1 in week 3; non recovering uterine environment (NRU): VDS $=2$ or 3 in week 3; ${ }^{\mathrm{c}}$ Keyhole limpet hemocyanin (KLH), lipopolysaccharide (LPS), glutamate dehydrogenase (GD), carbonic anhydrase (CA), myosin (MYO) and Transferrin (TRANS); ${ }^{\mathrm{d}} \mathrm{ROM}=$ Reactive oxygen metabolites; FRAP = Ferric-reducing antioxidant power. 


\subsection{Consequences of Maternal Dry Period Length on Colostrum Immunoglobulin Content and Immune Competence of Calves}

\subsubsection{Colostrum Immunoglobulin Content}

Cows with a 0-d dry period, but not cows with a 30-d dry period, had lower colostrum production, lower colostrum immunoglobulin (IgG and IgM) content and reduced NAb and NAAb titers in colostrum at first milking compared with cows with a 60-d dry period in both the first (Chapter 5) and second lactation (Figure 7.2). In addition, colostrum immunoglobulin content did not differ between cows with a 30-d dry period and cows with a 60-d dry period. Furthermore, there was no difference in colostrum NAb (Chapter 5) and NAAb titers (Chapter 6) between cows with 30-d and 60-d dry period in the first lactation and in the second lactation after implementation dry period length (Figure 7.3). Although IgG mass produced at day of calving was lower for cows with a 0-d dry period over 2 subsequent lactations, the total $\operatorname{IgG}$ mass produced during colostrogenesis was not different between cows with a 0-d and a 60-d dry period (Baumrucker et al., 2014).

Colostrum immunoglobulins in the mammary gland originate from systemic and local sources. Colostrum immunoglobulin content is influenced by many factors such as time of milking after calving (Pritchett et al., 1994), age of the cows (Meganck et al., 2012), nutrition of the cows before calving (Quigley Iii and Drewry, 1998), season and heat stress (Nardone et al., 1997, Morin et al., 2010). Results of the present study indicate that that colostrum production for cows with a 0 -d dry period is not compromised, but secretion is distributed over more days, resulting in a lower colostrum secretion at the day of calving (Baumrucker et al., 2014). It was suggested in earlier studies that providing a day or 2 non-milking prior to parturition would allow for the $\mathrm{IgG}$ to accumulate, thus the production and concentration of IgG would be higher in the following parturition (Baumrucker et al., 2014, Gross et al., 2014). Nevertheless, these results suggest that dry period length affect immunoglobulin content in colostrum thus also may affect immune competence of calves, since calves obtain passive immunity via colostrum. 

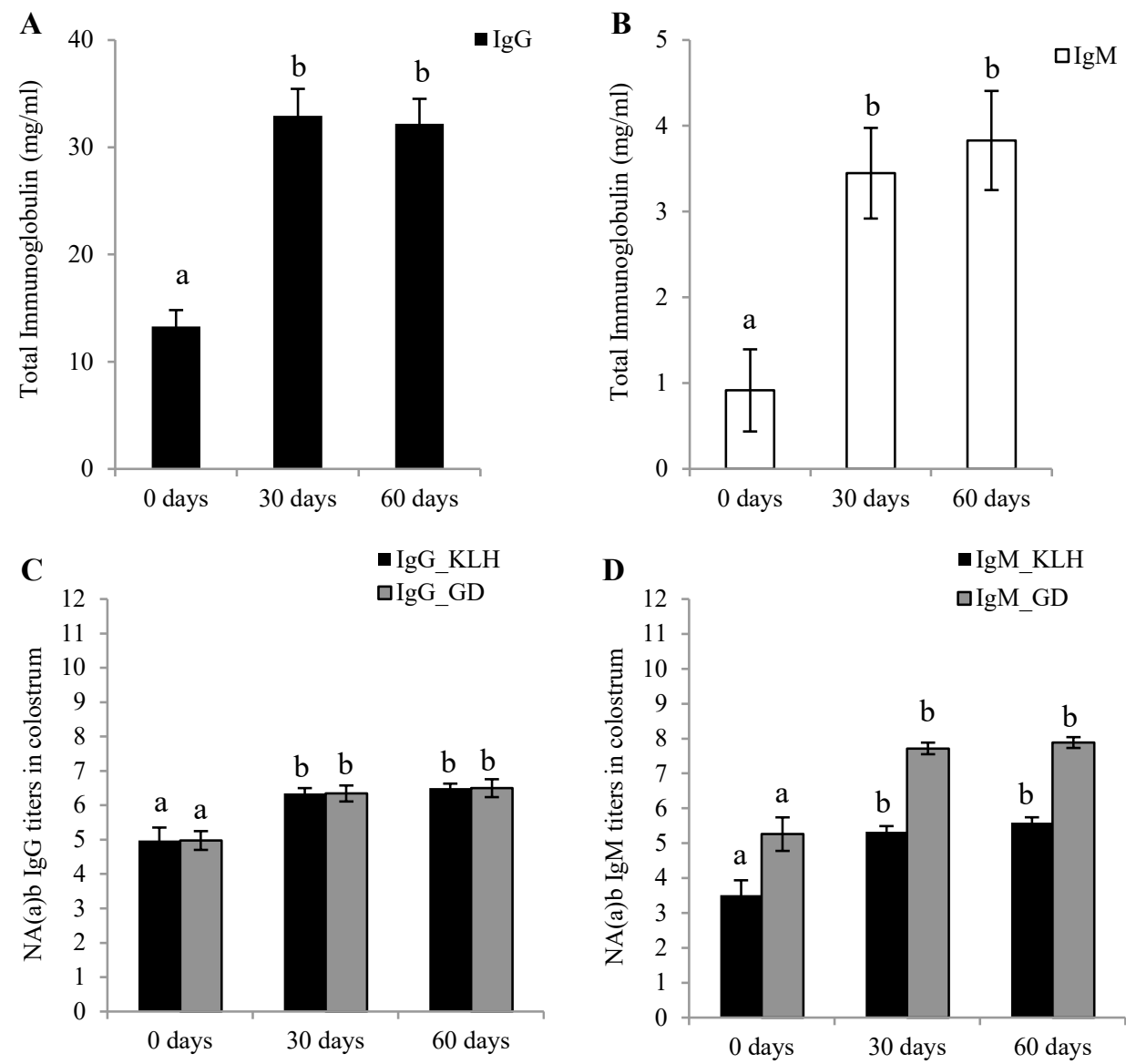

Figure 7.2 Concentration of $\operatorname{IgG}(\mathrm{A})$ and $\operatorname{IgM}(\mathrm{B})$, natural (auto) antibodies (NAAb) binding keyhole limpet hemocyanin (KLH) and glutamate dehydrogenase (GD) for isotype $\operatorname{IgG}(\mathrm{C})$ and $\operatorname{IgM}(\mathrm{D})$ in colostrum from cows with 3 different dry period lengths $(0,30$ or $60 \mathrm{~d})$ in the second lactation after implementation of dry period length treatments. Values are means $( \pm$ SEM) per dry period length. Bars within immunoglobulin type with different letters differ $(P<0.05)$.

\subsubsection{Natural (Auto) Antibody and Specific Antibody Titers in Plasma of Calves}

In the present study, NAAb (Chapter 6), but not NAb (Chapter 5) are already present in plasma of calves before colostrum intake after implementation of dry period length treatments. In the first lactation, omitting the dry period decreased NAb (Chapter 5) and NAAb titers (Chapter 6) in plasma of calves in the first week of life compared with shortening or a conventional dry period. Low $\mathrm{NAb}$ levels in plasma of calves are a reflection of low intake of NAb levels from 
colostrum. Colostrum NAb and NAAb have a positive correlation with NAb (Chapter 5) and NAAb (Chapter 6) in plasma of the calves in the first week of life. Albeit calves from cows with a 0 -d dry period had lower titers of NAb and $\mathrm{NAAb}$ in the first week of life, calves from cows with a $0-\mathrm{d}$ dry period eventually have similar titers of SpAb binding KLH and HuSA after primary immunization at week 6 after calving. In addition, SpAb in calves were not affected by the maternal dry period length. Even the secondary antibody response to KLH in calves from cows with a 0-d dry period were enhanced compared with calves from cows with a 30-d or 60-d dry period (Chapter 5). Uptake of sufficient colostrum is essential for calf health, growth and performance as a dairy cow (Morin et al., 2010, Meganck et al., 2012). However, it appears that temporarily lowered NAb and NAAb titers as found in calves from cows with no dry period in the present study had no consequences for disease incidence and immune competence of the calves during the first 3 months of life.

In the present study, there were no differences in growth and disease incidence of the calves during the first 12 weeks of life in both the first (Chapter 5) and second lactation after implementation of maternal dry period length treatments. In the second lactation, the 0-d dry period treatment is not included in the data because in this group 6 calves were twins ( 5 females and 1 male) and 19 cows were naturally dried off which were therefore included in the group of a 30-d dry period. In the second lactation, the body weight of female calves prior to first immunization at week 6 was not different between dry period lengths $(13.6 \mathrm{~kg}$ vs. $13.5 \mathrm{~kg} \pm 1$, a 30 -d vs. 60 -d dry period, $P=0.16$ ). The hygiene conditions in this study can be expected to be high. Calves from the present study were all raised at a specific calf raising farm from day 2 of life onwards. Davis and Drackley (1998) reported that the physical environmental conditions like housing and the level of hygiene will influence mortality and morbidity rates, effectiveness of good nutrition and management. In the present study no intentional infection was performed, therefore no information on disease resistance was obtained. In the second lactation, in total 9 calves out of 115 were infected by IBR (Infectious Bovine Rhinotracheitis) but this was not attributed to dry period length treatments (5 calves from cows with 60-d dry period and 4 calves from cows with 30-d dry period). No differences in antibody titers for KLH and HuSA were found in these calves. Further long-term studies are needed which monitor health of calves from cows with different dry period lengths under different conditions with larger number of animals. 

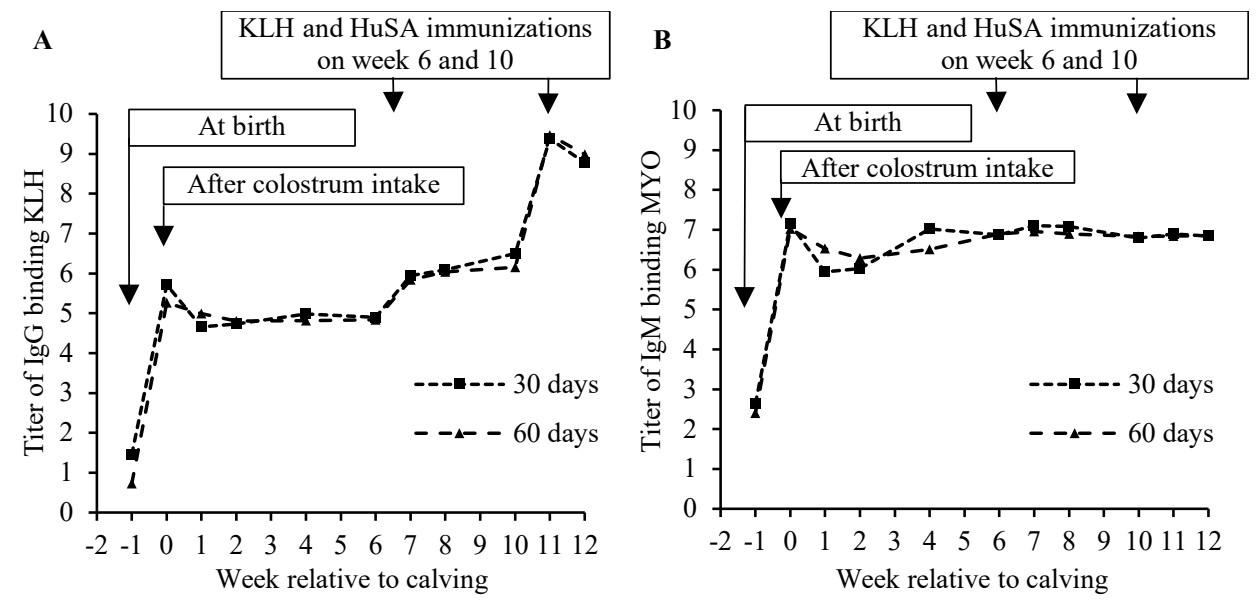

Figure 7.3 Natural (auto) antibodies (week 0 until week 6) and specific antibodies (after primary and secondary immunization of keyhole limpet hemocyanin (KLH) and human albumin serum (HuSA)) for immunoglobulin (Ig) G titer binding KLH (A), and for IgM binding myosin (MYO) (B) in plasma of female calves from dairy cows with a 30-d or 60-d dry period in the second lactation after implementation of dry period length treatments. Values represent means per dry period length per week.

\subsection{The Possible Application of Shortening or Omitting the Dry Period in Practice to Improve Animal Health and Welfare}

The feasibility of shortening or omitting the dry period to improve EB and animal health not only could be experimentally shown but was implemented in practice. In practice, some dairy farmers shifted their dry period management strategy from a conventional dry period to a management strategy with a shortened or omitted dry period. An earlier study involving 13 commercial Canadian dairy herds showed that some farmers are satisfied with the strategy of shortening the dry period (35-d) because of lower incidence of mild ketosis without any negative effects on other health problems (incidence of severe ketosis, displaced abomasum, milk fever, and mastitis) and reproduction (metritis) (Santschi et al., 2011). This study did not include a 0-d dry period length treatments. A study involving 11 commercial Dutch dairy herds showed that some farmers are satisfied with the no dry period strategy because of healthier cows, decreased work load due to less dietary and group transitions, and improved fertility, whereas two farmers stopped using it because of the lower milk yield (Steeneveld et al., 2013). A follow up study involving 16 commercial Dutch dairy herds showed that some farmers are able to apply a short or no dry period on their farm over 2 consecutive lactations without a change in quantity of milk losses (Kok et al., 2017). In this study, cows 
with a 30-d dry period had similar reduction in milk yield $(1 \mathrm{~kg} / \mathrm{d})$ compared with cows with a 60-d dry period over 2 consecutive lactations. Cows with a 0 -d dry period had reduced the additional milk yield before calving, but had increased the milk yield after calving, compared with the first omission of the dry period, which results in the same total quantity of milk losses ( $2 \mathrm{~kg} / \mathrm{d}$ ) (Kok et al., 2017). Earlier, it was suggested that farmers may use characteristics of individual cows, like parity or milk production level, to predict milk yield for individual cows in response to dry period length (Kok et al., 2017). However, it is still questioned whether omitting the dry period is beneficial for dairy cows welfare (Zobel et al., 2015). Planned stop milking before calving was shown to increase udder pressure and stress (as measured by faecal glucocorticoid metabolites) at the start of the dry period (Tucker et al.,2009, Bertulat et al., 2013) which can be expected to affect animal welfare. Cows with a 0-d dry period can be kept in the herd without regrouping and dietary changes. From this perspective, we assume that cows with 0 -d dry period have less stress and therefore an improved welfare. Further study is needed to confirm whether shortening the dry period affects animal welfare.

From the economic point of view, cows with a omitted dry period had lower cost for antibiotic use and reduced management costs for regrouping the cows and dietary changes (Steeneveld et al., 2013). Earlier study involving 13 commercial Canadian dairy herds showed that shortening the dry period (35-d) would be more beneficial compared with a conventional dry period (60-d) due to additional milk yield in the precalving period, lower replacement rate, and a shorter calving interval (Santschi et al., 2011). However, knowledge about the economic impact of omitting the dry period is scarce. A field study with a large number of animals is needed to evaluate the economic impact of omitting the dry period based on health and fertility.

\subsection{Conclusion}

Omitting the dry period improved EB, metabolic status and fertility. The current study shows that omitting the dry period reduced plasma bilirubin level but does not have clear consistent effects on inflammation or oxidative stress compared with a short or a conventional dry period in the first and second lactation after implementation of dry period length treatments. Better liver functionality in cows with a 0-d dry period was associated with improved EB in these cows. Omitting the dry period increased both positive and negative APP, oxidative stress, and resulted in higher NAb and NAAb in plasma compared with a short or a conventional dry 
period. Effects of dry period length on health variables such as APP, liver functionality markers, oxidative stress markers and NAb depend on many factors, like EB, mammary health, clinical health problems related to inflammation, BCS, and uterine health status. Changes in inflammatory variables (increased ceruloplasmin), oxidative stress marker (increased ROM) and higher NAb IgG binding LPS in plasma were a reflection of the occurrence of health problems related to inflammation. In particular clinical mastitis and reduced uterine health had consequences for the monitored variables related to inflammation, oxidative stress and humoral immune response of cows in early lactation, independent of dry period length. In the first lactation after implementation dry period length and dietary treatments, feeding a glucogenic ration in early lactation increased $\operatorname{IgM}$ NAb titers binding LPS in milk compared with a lipogenic ration, which could be explained partly by better EB. In the second lactation after implementation dry period length and dietary treatments, feeding a lipogenic ration in early lactation increased cholesterol levels in plasma compared with a glucogenic ration, which could be explained by high fat content in this ration. Albeit omitting the dry period in cows resulted in reduced immunoglobulin content in colostrum and NAb and NAAb levels in plasma of their calves in the first week of life, this did not affect specific immune response and growth of the calves at least in the first 12 weeks of life. The titers of NAAb in plasma of the calves were not related to NAAB in plasma of their mother before colostrum intake, but in the first week of life there was a relation with NAAB in plasma of the mother, which disappeared again thereafter. In addition, NAb and NAAb in plasma are influenced by the age of the mother. Maternal dry period length had temporary transgenerational effects on calves. 


\section{References}

Abuelo, A., J. Hernández, J. L. Benedito, and C. Castillo. 2015. The importance of the oxidative status of dairy cattle in the periparturient period: Revisiting antioxidant supplementation. J. Anim. Physiol. Anim. Nut. 99:1003-1016.

Ametaj, B. N., S. Iqbal, F. Selami, J. F. Odhiambo, Y. Wang, M. G. Gänzle, S. M. Dunn, and Q. Zebeli. 2014. Intravaginal administration of lactic acid bacteria modulated the incidence of purulent vaginal discharges, plasma haptoglobin concentrations, and milk production in dairy cows. Res. Vet. Sci. 96:365-370.

Andersen, J. B., T. G. Madsen, T. Larsen, K. L. Ingvartsen, and M. O. Nielsen. 2005. The effects of dry period versus continuous lactation on metabolic status and performance in periparturient cows. J. Dairy Sci. 88:3530-3541.

Annen, E. L., R. J. Collier, M. A. McGuire, J. L. Vicini, J. M. Ballam, and M. J. Lormore. 2004. Effect of modified dry period lengths and bovine somatotropin on yield and composition of milk from dairy cows. J. Dairy Sci. 87:3746-3761.

Assenat, E., S. Gerbal. Chaloin, D. Larrey, J. Saric, J. Fabre, P. Maurel, M. Vilarem, and J. M. Pascussi. 2004. Interleukin $1 \beta$ inhibits CAR induced expression of hepatic genes involved in drug and bilirubin clearance. Hepatol. 40:951-960.

Aviram, M. and M. Rosenblat. 2004. Paraoxonases 1, 2, and 3, oxidative stress, and macrophage foam cell formation during atherosclerosis development. Free Radical Bio. Med. 37:1304-1316.

Baumann, H. and J. Gauldie. 1994. The acute phase response. Immunol. Today 15:74-80.

Baumgarth, N., J. W. Tung, and L. A. Herzenberg. 2005. Inherent specificities in natural antibodies: A key to immune defense against pathogen invasion. Springer Semin. Immunopathol. 26:347-362.

Baumrucker, C. R., R. S. Zbinden, H. A. van Dorland, G. J. Remmelink, B. Kemp, A. T. M. van Knegsel, and R. M. Bruckmaier. 2014. Continuous milking of dairy cows disrupts timing of peak $\mathrm{IgG}$ concentration appearance in mammary secretions. J. Dairy Res.:1-7.

Bell, L. N., J. L. Theodorakis, R. Vuppalanchi, R. Saxena, K. G. Bemis, M. Wang, and N. Chalasani. 2010. Serum proteomics and biomarker discovery across the spectrum of nonalcoholic fatty liver disease. Hepatol. 51:111-120.

Bernabucci, U., B. Ronchi, N. Lacetera, and A. Nardone. 2005. Influence of body condition score on relationships between metabolic status and oxidative stress in periparturient dairy cows. J. Dairy Sci. 88:2017-2026.

Bertoni, G., E. Trevisi, and R. Lombardelli. 2009. Some new aspects of nutrition, health conditions and fertility of intensively reared dairy cows. Italian J. Anim. Sci. 8:491518.

Bertoni, G., E. Trevisi, X. Han, and M. Bionaz. 2008. Effects of inflammatory conditions on liver activity in puerperium period and consequences for performance in dairy cows. J. Dairy Sci. 91:3300-3310.

Bionaz, M., E. Trevisi, L. Calamari, F. Librandi, A. Ferrari, and G. Bertoni. 2007. Plasma paraoxonase, health, inflammatory conditions, and liver function in transition dairy cows. J. Dairy Sci. 90:1740-1750.

Booth, C. J., L. D. Warnick, Y. T. Gröhn, D. O. Maizon, C. L. Guard, and D. Janssen. 2004. Effect of lameness on culling in dairy cows. J. Dairy Sci. 87:4115-4122. 
Butler, W. R. 2003. Energy balance relationships with follicular development, ovulation and fertility in postpartum dairy cows. Livestock Prod. Sci. 83:211-218.

Carlén, E., E. Strandberg, and A. Roth. 2004. Genetic parameters for clinical mastitis, somatic cell score, and production in the first three lactations of swedish holstein cows. J. Dairy Sci. 87:3062-3070.

Carroll, D. J., M. J. Jerred, R. R. Grummer, D. K. Combs, R. A. Pierson, and E. R. Hauser. 1990. Effects of fat supplementation and immature alfalfa to concentrate ratio on plasma progesterone, energy balance, and reproductive traits of dairy cattle. J. Dairy Sci. 73:2855-2863.

Chapinal, N., M. Carson, T. F. Duffield, M. Capel, S. Godden, M. Overton, J. E. P. Santos, and S. J. LeBlanc. 2011. The association of serum metabolites with clinical disease during the transition period. J. Dairy Sci. 94:4897-4903.

Chassagne, M., J. Barnouin, and J. P. Chacornac. 1998. Biological predictors for early clinical mastitis occurrence in Holstein cows under field conditions in France. Prev. Vet. Med. 35:29-38.

Chen, J., G. J. Remmelink, J. J. Gross, R. M. Bruckmaier, B. Kemp, and A. T. M. van Knegsel. 2016. Effects of dry period length and dietary energy source on milk yield, energy balance, and metabolic status of dairy cows over 2 consecutive years: Effects in the second year. J. Dairy Sci. 99:4826-4838.

Chen, J., J. J. Gross, H. A. van Dorland, G. J. Remmelink, R. M. Bruckmaier, B. Kemp, and A. T. M. van Knegsel. 2015a. Effects of dry period length and dietary energy source on metabolic status and hepatic gene expression of dairy cows in early lactation. J. Dairy Sci. 98:1033-1045.

Chen, J., N. M. Soede, H. A. van Dorland, G. J. Remmelink, R. M. Bruckmaier, B. Kemp, and A. T. M. van Knegsel. 2015b. Relationship between metabolism and ovarian activity in dairy cows with different dry period lengths. Theriogenology 84(8):13871396.

Cojocaru, M., I. M. Cojocaru, and I. Silosi. 2009. The significance of natural autoantibodies. Maedica (Buchar) 4:22-25.

Collard, B. L., P. J. Boettcher, J. C. M. Dekkers, D. Petitclerc, and L. R. Schaeffer. 2000. Relationships between energy balance and health traits of dairy cattle in early lactation. J. Dairy Sci. 83:2683-2690.

Conner, J. G., P. D. Eckersall, A. Wiseman, T. C. Aitchison, and T. A. Douglas. 1988. Bovine acute phase response following turpentine injection. Res. Vet. Sci. 44:82-88.

Davis, C. L. and Drackley, J. K. 1998. The development, nutrition, and management of the young calf. 1st ed. Iowa State Univ. Press. Ames, Iowa.

de Feu, M. A., A. C. O. Evans, P. Lonergan, and S. T. Butler. 2009. The effect of dry period duration and dietary energy density on milk production, bioenergetic status, and postpartum ovarian function in Holstein-Friesian dairy cows. J. Dairy Sci. 92:6011-6022.

Dubuc, J., T. F. Duffield, K. E. Leslie, J. S. Walton, and S. J. LeBlanc. 2010. Risk factors for postpartum uterine diseases in dairy cows. J. Dairy Sci. 93:5764-5771.

Eckersall, P. D. and R. Bell. 2010. Acute phase proteins: Biomarkers of infection and inflammation in veterinary medicine. The Vet. J. 185:23-27.

Enevoldsen, C. and J. T. Sørensen. 1992. Effects of dry period length on clinical mastitis and other major clinical health disorders. J. Dairy Sci. 75:1007-1014. 
Esposito, G., P. C. Irons, E. C. Webb, and A. Chapwanya. 2014. Interactions between negative energy balance, metabolic diseases, uterine health and immune response in transition dairy cows. Animal Reprod. Sci. 144:60-71.

Ferré, N., J. Camps, E. Prats, E. Vilella, A. Paul, L. Figuera, and J. Joven. 2002. Serum paraoxonase activity: a new additional test for the improved evaluation of chronic liver damage. Clinical Chem. 48:261-268.

Gilbert, R. O., S. T. Shin, C. L. Guard, H. N. Erb, and M. Frajblat. 2005. Prevalence of endometritis and its effects on reproductive performance of dairy cows. Theriogenol. 64:1879-1888.

Goff, J. P. and R. L. Horst. 1997. Physiological changes at parturition and their relationship to metabolic disorders. J. Dairy Sci. 80.

Graugnard, D. E., M. Bionaz, E. Trevisi, K. M. Moyes, J. L. Salak-Johnson, R. L. Wallace, J. K. Drackley, G. Bertoni, and J. J. Loor. 2012. Blood immunometabolic indices and polymorphonuclear neutrophil function in peripartum dairy cows are altered by level of dietary energy prepartum1. J. Dairy Sci. 95:1749-1758.

Gross, J. J., E. C. Kessler, V. Bjerre-Harpoth, C. Dechow, C. R. Baumrucker, and R. M. Bruckmaier. 2014. Peripartal progesterone and prolactin have little effect on the rapid transport of immunoglobulin $G$ into colostrum of dairy cows. J. Dairy Sci. 97:2923-2931.

Grummer, R. R. 1993. Etiology of lipid-related metabolic disorders in periparturient dairy cows. J. Dairy Sci. 76:3882-3896.

Gruys, E., M. J. M. Toussaint, T. A. Niewold, and S. J. Koopmans. 2005. Acute phase reaction and acute phase proteins. J Zhejiang Univ: Sci 6 B:1045-1056.

Gümen, A., R. R. Rastani, R. R. Grummer, and M. C. Wiltbank. 2005. Reduced dry periods and varying prepartum diets alter postpartum ovulation and reproductive measures. J. Dairy Sci. 88:2401-2411.

Huzzey, J. M., T. F. Duffield, S. J. LeBlanc, D. M. Veira, D. M. Weary, and M. A. G. Von Keyserlingk. 2009. Short communication: Haptoglobin as an early indicator of metritis. J. Dairy Sci. 92:621-625.

Ingvartsen, K. L. and K. Moyes. 2013. Nutrition, immune function and health of dairy cattle. Anim. 7:112-122.

Jacometo, C. B., J. S. Osorio, M. Socha, M. N. Corrêa, F. Piccioli-Cappelli, E. Trevisi, and J. J. Loor. 2015. Maternal consumption of organic trace minerals alters calf systemic and neutrophil mRNA and microRNA indicators of inflammation and oxidative stress. J. Dairy Sci. 98:7717-7729.

James, R. W. and S. P. Deakin. 2004. The importance of high-density lipoproteins for paraoxonase-1 secretion, stability, and activity. Free Radical Biology and Med. 37:1986-1994.

Kaneene, J. B., R. Miller, T. H. Herdt, and J. C. Gardiner. 1997. The association of serum nonesterified fatty acids and cholesterol, management and feeding practices with peripartum disease in dairy cows. Prev. Vet. Med. 31:59-72.

Kok, A., A. T. M. van Knegsel, C. E. van Middelaar, B. Engel, H. Hogeveen, B. Kemp, and I. J. M. de Boer. 2017. Effect of dry period length on milk yield over multiple lactations. J. Dairy Sci. 100:739-749.

Kokkonen, T., J. Taponen, T. Anttila, L. Syrjälä-Qvist, C. Delavaud, Y. Chilliard, M. Tuori, and A. T. Tesfa. 2005. Effect of body fatness and glucogenic supplement on lipid and protein mobilization and plasma leptin in dairy cows. J. Dairy Sci. 88:11271141 . 
Konvičná, J., M. Vargová, I. Paulíková, G. Kováč, and Z. Kostecká. 2015. Oxidative stress and antioxidant status in dairy cows during prepartal and postpartal periods. Acta Vet. Brno 84:133-140.

Lacetera, N., D. Scalia, U. Bernabucci, B. Ronchi, D. Pirazzi, and A. Nardone. 2005. Lymphocyte functions in overconditioned cows around parturition. J. Dairy Sci. 88:2010-2016

LeBlanc, S. J. 2012. Interactions of metabolism, inflammation, and reproductive tract health in the postpartum period in dairy cattle. Reprod. Domest. Anim. 47:18-30.

LeBlanc, S. J., T. F. Duffield, K. E. Leslie, K. G. Bateman, G. P. Keefe, J. S. Walton, and W. H. Johnson. 2002. Defining and diagnosing postpartum clinical endometritis and its impact on reproductive performance in dairy cows. J. Dairy Sci. 85:2223-2236.

Mallard, B. A., J. C. Dekkers, M. J. Ireland, K. E. Leslie, S. Sharif, C. L. Vankampen, L. Wagter, and B. N. Wilkie. 1998. Alteration in immune responsiveness during the peripartum period and its ramification on dairy cow and calf health. J. Dairy Sci. 81:585-595.

Meganck, V., J. Laureyns, and G. Opsomer. 2012. The importance of a proper colostrum management in modern cattle farms. Vlaam. Diergeneeskd. Tijdschr. 81:373-381.

Mihaylova, N.M., Dimitrov, J.D., Djoumerska-Alexieva, I.K., Vassilev, T.L., 2008. Inflammation-induced enhancement of IgG immunoreactivity. Inflam. Res. 57,1-3.

Minuti, A., Z. Zhou, D. E. Graugnard, S. L. Rodriguez, Zas, A. R. Palladino, F. C. Cardoso, E. Trevisi, and J. J. Loor. 2015. Acute mammary and liver transcriptome responses after an intramammary Escherichia coli lipopolysaccharide challenge in postpartal dairy cows. Physiol. Reports 3.

Morin, D. E., S. V. Nelson, E. D. Reid, D. W. Nagy, G. E. Dahl, and P. D. Constable. 2010. Effect of colostral volume, interval between calving and first milking, and photoperiod on colostral IgG concentrations in dairy cows. J. Am. Vet. Med. Assoc. 237:420-428.

Nardone, A., N. Lacetera, U. Bernabucci, and B. Ronchi. 1997. Composition of colostrum from dairy heifers exposed to high air temperatures during late pregnancy and the early postpartum period. J. Dairy Sci. 80:838-844.

Ochsenbein, A. F., T. Fehr, C. Lutz, M. Suter, F. Brombacher, H. Hengartner, and R. M. Zinkernagel. 1999. Control of early viral and bacterial distribution and disease by natural antibodies. Sci. 286:2156-2159.

Ospina, P. A., D. V. Nydam, T. Stokol, and T. R. Overton. 2010a. Associations of elevated nonesterified fatty acids and $\beta$-hydroxybutyrate concentrations with early lactation reproductive performance and milk production in transition dairy cattle in the northeastern United States. J. Dairy Sci. 93:1596-1603.

Ospina, P. A., D. V. Nydam, T. Stokol, and T. R. Overton. 2010b. Evaluation of nonesterified fatty acids and $\beta$-hydroxybutyrate in transition dairy cattle in the northeastern United States: Critical thresholds for prediction of clinical diseases. J. Dairy Sci. 93:546-554.

Pedernera, M., P. Celi, S. C. García, H. E. Salvin, I. Barchia, and W. J. Fulkerson. 2010. Effect of diet, energy balance and milk production on oxidative stress in earlylactating dairy cows grazing pasture. The Vet. J. 186:352-357.

Petersen, H. H., J. P. Nielsen, and P. M. H. Heegaard. 2004. Application of acute phase protein measurements in veterinary clinical chemistry. Vet. Res. 35:163-187.

Ploegaert, T. C. W., S. Wijga, E. Tijhaar, J. J. Van der Poel, T. J. G. M. Lam, H. F. J. Savelkoul, H. K. Parmentier, and J. A. M. Van Arendonk. 2010. Genetic variation of 
natural antibodies in milk of Dutch Holstein-Friesian cows. J. Dairy Sci. 93:54675473.

Pritchett, L. C., C. C. Gay, D. D. Hancock, and T. E. Besser. 1994. Evaluation of the hydrometer for testing immunoglobulin G1 concentrations in Holstein colostrum. J. Dairy Sci. 77:1761-1767.

Prunner, I., H. Pothmann, K. Wagener, M. Giuliodori, J. T. Huber, M. Ehling-Schulz, and M. Drillich. 2014. Dynamics of bacteriologic and cytologic changes in the uterus of postpartum dairy cows. Theriogenol. 82:1316-1322.

Pyörälä, S. 2003. Indicators of inflammation in the diagnosis of mastitis. Vet. Res. 34:565578.

Qualmann, K., J. Rehage, M. Beyerbach, and H. Scholz. 1997. Hyperbilirubinemia in dairy cows with lipomobilisation syndrome and its relation to high serum concentrations of non esterified fatty acids. in Proc. Proceedings, IXth International Conference on Production Diseases in Farm Animals 1995: September 11-14, 1995, Free University of Berlin. Stuttgart: Ferdinand Enke Verlag, 1997.

Quigley Iii, J. D. and J. J. Drewry. 1998. Nutrient and immunity transfer from cow to calf pre- and postcalving. J. Dairy Sci. 81:2779-2790.

Rastani, R. R., R. R. Grummer, S. J. Bertics, A. Gümen, M. C. Wiltbank, D. G. Mashek, and M. C. Schwab. 2005. Reducing dry period length to simplify feeding transition cows: milk production, energy balance, and metabolic profiles. J. Dairy Sci. 88:1004-1014.

Santschi, D. E., D. M. Lefebvre, R. I. Cue, C. L. Girard, and D. Pellerin. 2011. Completelactation milk and component yields following a short (35-d) or a conventional (60-d) dry period management strategy in commercial Holstein herds. J. Dairy Sci. 94:2302-2311.

Schlamberger, G., Wiedemann, S., Viturro, E., Meyer, H.H., Kaske, M., 2010. Effects of continuous milking during the dry period or once daily milking in the first 4 weeks of lactation on metabolism and productivity of dairy cows. J. Dairy Sci. 93, 24712485.

Schneider, A., M. N. Corrêa, and W. R. Butler. 2013. Short communication: Acute phase proteins in Holstein cows diagnosed with uterine infection. Res. Vet. Sci. 95:269271.

Seifi, H. A., S. J. LeBlanc, K. E. Leslie, and T. F. Duffield. 2011. Metabolic predictors of post-partum disease and culling risk in dairy cattle. Vet. J. 188:216-220.

Sheldon, I. M., D. E. Noakes, A. Rycroft, and H. Dobson. 2001. Acute phase protein responses to uterine bacterial contamination in cattle after calving. Vet. Rec. 148:172-175.

Sordillo, L. M., G. Contreras, and S. L. Aitken. 2009. Metabolic factors affecting the inflammatory response of periparturient dairy cows. Anim. Health Res. Rev 10:5363.

Spears, J. W. and W. P. Weiss. 2008. Role of antioxidants and trace elements in health and immunity of transition dairy cows. The Vet. J. 176:70-76.

Steeneveld, W., Y. H. Schukken, A. T. M. van Knegsel, and H. Hogeveen. 2013. Effect of different dry period lengths on milk production and somatic cell count in subsequent lactations in commercial Dutch dairy herds. J. Dairy Sci. 96:2988-3001.

Thompson-Crispi, K. A., F. Miglior, and B. A. Mallard. 2013. Genetic parameters for natural antibodies and associations with specific antibody and mastitis in Canadian Holsteins. J. Dairy Sci. 96:3965-3972. 
Trevisi, E., A. Zecconi, G. Bertoni, and R. Piccinini. 2010. Blood and milk immune and inflammatory profiles in periparturient dairy cows showing a different liver activity index. J. Dairy Res.77:310-317.

Trevisi, E., M. Amadori, A. M. Bakudila, and G. Bertoni. 2009. Metabolic changes in dairy cows induced by oral, low-dose interferon-alpha treatment. J. Animal Sci. 87:30203029.

Trevisi, E., M. Amadori, I. Archetti, N. Lacetera, and G. Bertoni. 2011. Inflammatory response and acute phase proteins in the transition period of high-yielding dairy cows. F. Veas (Ed.), Acute Phase Proteins (2nd), InTech, Rijeka, Croatia (2011) :355-380.

Trevisi, E., M. Amadori, S. Cogrossi, E. Razzuoli, and G. Bertoni. 2012. Metabolic stress and inflammatory response in high-yielding, periparturient dairy cows. Res. Vet. Sci. 93:695-704.

Turk, R., C. Piras, M. Kovačić, M. Samardžija, H. Ahmed, M. De Canio, A. Urbani, Z. F. Meštrić, A. Soggiu, L. Bonizzi, and P. Roncada. 2012. Proteomics of inflammatory and oxidative stress response in cows with subclinical and clinical mastitis. J. Proteomics 75:4412-4428.

Turk, R., D. Juretic, D. Geres, N. Turk, B. Rekic, V. Simeon-Rudolf, and A. Svetina. 2004. Serum paraoxonase activity and lipid parameters in the early postpartum period of dairy cows. Res. Vet. Sci. 76:57-61.

Van Altena, S. E. C. 2016. Biomarkers and mechanisms of natural disease resistance in dairy cows. Wageningen University.

Van Knegsel, A. T. M., G. de Vries Reilingh, S. Meulenberg, H. van den Brand, J. Dijkstra, B. Kemp, and H. K. Parmentier. 2007a. Natural antibodies related to energy balance in early lactation dairy cows. J. Dairy Sci. 90:5490-5498.

Van Knegsel, A. T. M., G. J. Remmelink, S. Jorjong, V. Fievez, and B. Kemp. 2014b. Effect of dry period length and dietary energy source on energy balance, milk yield, and milk composition of dairy cows. J. Dairy Sci. 97:1499-1512.

Van Knegsel, A. T. M., H. M. Hammon, U. Bernabucci, G. Bertoni, R. M. Bruckmaier, R. M. A. Goselink, J. J. Gross, B. Kuhla, C. C. Metges, and H. K. Parmentier. 2014a. Metabolic adaptation during early lactation: key to cow health, longevity and a sustainable dairy production chain. CAB Rev. 9:15.

Van Knegsel, A. T. M., H. van den Brand, J. Dijkstra, W. M. van Straalen, M. J. W. Heetkamp, S. Tamminga, and B. Kemp. 2007b. Dietary energy source in dairy cows in early lactation: energy partitioning and milk composition. J. Dairy Sci. 90:14671476.

Van Knegsel, A. T. M., Hostens, M., de Vries Reilingh, G., Lammers, A., Kemp, B., Opsomer, G., Parmentier, H. K., 2012. Natural antibodies related to metabolic and mammary health in dairy cows. Prev. Vet. Med. 103, 287-297.

Van Knegsel, A. T. M., S. G. A. van der Drift, J. Čermáková, and B. Kemp. 2013. Effects of shortening the dry period of dairy cows on milk production, energy balance, health, and fertility: A systematic review. The Vet. J. 198:707-713.

Walsh, R. B., J. S. Walton, D. F. Kelton, S. J. LeBlanc, K. E. Leslie, and T. F. Duffield. 2007. The effect of subclinical ketosis in early lactation on reproductive performance of postpartum dairy cows. J. Dairy Sci. 90:2788-2796.

West, H. J. 1990. Effect on liver function of acetonaemia and the fat cow syndrome in cattle. Res. Vet. Sci. 48:221-227. 
Williams, E. J., D. P. Fischer, D. U. Pfeiffer, G. C. W. England, D. E. Noakes, H. Dobson, and I. M. Sheldon. 2005. Clinical evaluation of postpartum vaginal mucus reflects uterine bacterial infection and the immune response in cattle. Theriogenol. 63:102117.

Wullepit, N., M. Hostens, C. Ginneberge, V. Fievez, G. Opsomer, D. Fremaut, and S. De Smet. 2012. Influence of a marine algae supplementation on the oxidative status of plasma in dairy cows during the periparturient period. Prev. Vet. Med. 103:298-303.

Zinkernagel, R. M. 2012. Immunological memory protective immunity. Cell. Mol. Life Sci. 69:1635-1640.

Zobel, G., D. M. Weary, K. E. Leslie, and M. A. G. von Keyserlingk. 2015. Invited review: Cessation of lactation: Effects on animal welfare. J. Dairy Sci. 98:8263-8277. 
Summary 
During early lactation, modern high-producing dairy cows typically experience a period with a negative energy balance (NEB). The NEB results from a sudden increase in milk production after calving while feed intake capacity is limited in this period. The severe NEB results in extensive mobilization of body reserves in early lactation in dairy cows. A high mobilization of free fatty acid (FFA) is related to an increased occurrence of metabolic disorders like liver fattening and ketosis, higher incidence of infectious diseases, immunosuppression, inflammation and oxidative stress. Moreover, cows with NEB had a compromised liver functions and increased oxidative stress. Extensive research efforts have been made to improve the energy balance (EB) in early lactation in dairy cows. Shortening or omitting the dry period shifts milk yield partially from the critical period after calving to the period before calving. The reduction in milk yield in early lactation results in an improvement of $\mathrm{EB}$, metabolic status, and fertility of dairy cows in early lactation. It can be hypothesized that improvement of the EB due to a short or no dry period improves health and reduces the occurrence of clinical health problems in early lactation. Studies on the effects of dry period length on health are limited and mostly limited in animal numbers. The first objective of this thesis was to study the effects of shortening the dry period on health related variables (inflammatory biomarkers, markers for liver functionality, oxidative stress and natural antibodies (NAb)) in dairy cows for multiple lactations. The second objective was to study the effects of dry period length on colostrum immunoglobulin content, natural (auto) and specific antibodies in plasma of calves for multiple lactations. Earlier, it was reported that feeding a glucogenic ration compared with a lipogenic ration in early lactation improved EB and metabolic status by reducing milk energy output. Shortening or omitting the dry period might reduce the requirement for glucogenic nutrients in early lactation because of the improved EB and metabolic status. Thus, it can be hypothesized that feeding a glucogenic ration may have less impact on EB but also may reduce inflammation, immunosuppression and oxidative stress in early lactation in dairy cows if cows have a better EB due to the shortened or omitted dry period.

To address these hypotheses, an experiment was performed where HolsteinFriesian dairy cows $(\mathrm{N}=167)$ were assigned randomly to 3 dry period lengths $(0$, 30 , or $60 \mathrm{~d}$ ) and 2 early lactation rations (glucogenic or lipogenic ration). Cows were fed a glucogenic or lipogenic ration from $10 \mathrm{~d}$ before the expected calving date. Cows were planned to have the same dry period length and dietary treatments for 2 subsequent lactations. Before calving of the second subsequent lactation, 19 
out of 39 cows in the 0 -d dry period group were attributed to $0 \rightarrow 30$-d dry period group (actual days dry: $67 \pm 8 \mathrm{~d}$ ) because these cows had a milk yield of $<4 \mathrm{~kg} / \mathrm{d}$ at least $30-\mathrm{d}$ before expected calving date and were allowed to go dry.

In the first subsequent lactation after implementation of dry period length treatments, cows with a 0-d dry period had higher levels of cholesterol (negative APP), ceruloplasmin (positive APP), reactive metabolite oxygen (ROM) and tended to have higher haptoglobin levels compared with cows with a 30-d or a 60-d dry period (Chapter 2). Cows with a 0 -d dry period had a lower plasma paraoxonase and bilirubin levels in the first 2 weeks after calving and a lower liver functionality index (LFI) compared with cows with a 60-d dry period. Cows with a 30 -d dry period did not differ on bilirubin levels compared with cows with a 0 -d or $60-\mathrm{d}$ dry period. It was questioned if dry period length effects on inflammatory and oxidative stress variables could be explained by dry period length effects on EB, mammary health or occurrence of clinical health problems. High levels of ceruloplasmin and ROM were explained by the occurrence of health problems related to inflammation. Low bilirubin levels were associated with better EB. Feeding a glucogenic ration did not affect levels of positive APP, bilirubin, and oxidative stress, but improved cholesterol levels in plasma compared with a more lipogenic ration. In conclusion, cows with a 0 -d dry period not only had a better EB, but also had higher levels of positive APP (ceruloplasmin) and oxidative stress compared with cows with a 30-d or 60-d dry period. No consistent effects of dry period length on inflammatory variables were observed. Moreover, occurrence of health problems did not differ between cows with different dry period lengths.

In the second lactation after implementation of dry period length and dietary treatments, the relationship between uterine health with inflammatory biomarkers and oxidative stress of dairy cows in early lactation was assessed (Chapter 3). Uterine health status (UHS) was monitored by scoring vaginal discharge (VD) based on a 4-point scoring system $(0,1,2$ or 3$)$ in week 2 and 3 after calving. Cows were classified as having a healthy uterine environment $(\mathbf{H U}, \mathrm{VDS}=0$ or 1 in both week 2 and 3), non- recovering uterine environment (NRU, VDS $=2$ or 3 in week 3 ) or a recovering uterine environment $(\mathbf{R U}, \mathrm{VDS}=2$ or 3 in week 2 and $\operatorname{VDS}=0$ or 1 in week 3). Cows with HU had lower levels of haptogloblin and higher paraoxonase in plasma compared with cows with NRU. Cows with RU had higher levels of albumin and creatinine plasma and a higher LFI compared with cows with NRU. Independent of UHS, cows in the $0 \rightarrow 30$-d dry period group had higher bilirubin and creatinine levels in plasma, which was related to more severe NEB in 
these cows. This study suggests that the also uterine health status explains peripartum changes in inflammatory biomarkers.

Mammary health and NAb in plasma and milk of cows with different dry period length were determined in both first and second lactation after implementation of dry period length and dietary treatments (Chapter 4). In the first lactation after implementation of dry period length treatments, cows with a 0-d dry period had higher somatic cell count (SCC), NAb (IgG and IgM) titers in milk and IgG binding lipopolysaccharide (LPS) in plasma compared with cows with a 30 -d or 60-d dry period. In the second lactation after implementation of dry period length and dietary treatments, cows with a 0 -d and 60-d dry period had a lower SCC compared with cows with a 30-d dry period and cows which were planned for 0 -d but they dried themselves off $(0 \rightarrow 30-d)$ dry periods. In the second lactation after implementation of dry period length treatments, dry period length did not affect NAb titers in plasma or milk. In both lactations, ration did not affect NAb titers in plasma. The clinical mastitis occurrence was 17 percent in lactation 1 of the experiment and 25 percent in lactation 2, and did not differ according to dry period lengths or rations. For both lactations, an increasing titer of IgG binding LPS in plasma was associated with decreased odds of a high SCC and decreased odds of clinical mastitis occurrence. Also up to 3 weeks before the clinical mastitis occurrence, increasing titers of IgM binding KLH and LPS in plasma was associated with decreased odds of clinical mastitis occurrence. In conclusion, omitting the dry period increased SCC, NAb titers in milk and IgG binding LPS in plasma compared with a short (30-d) or conventional (60-d) dry period. The effects on NAb titers, however, were only present in the first year after omitting the dry period and disappeared after repeated omitting the dry period. Moreover, an increasing titer of IgG binding LPS in plasma was associated with a decreased odds of high SCC and clinical mastitis occurrence.

The effect of maternal dry period length on colostrum immunoglobulin content and immune competence of their calves was determined in the first year after implementation dry period length treatments (Chapter 5). Birth weight of calves from cows with a 0 -d dry period was lower compared with calves from cows with a 30-d dry period, but not compared with calves from cows with a 60-d dry period. Growth of calves until 12 weeks of life was not affected by dry period length. Cows with a 0-d or 30-d dry period had lower colostrum production at first milking after calving compared with cows with a 60-d dry period. Total IgG and IgM concentration in colostrum, NAb IgG and IgM titers binding KLH or HuSA 
were lower in colostrum from cows with a 0 -d dry period compared with cows with a 30-d or 60-d dry period, which may be explained because Ig production during the prepartum period for cows with a 0 -d dry period was already lost in milk before parturition, compared with cows with a dry period. Natural antibody titers (IgG, IgM and IgT) binding KLH or HuSA in plasma were lower during the first 2 weeks of life for calves from cows with a 0-d dry period compared with calves from cows with a 30-d or 60-d dry period. Female calves were immunized with both KLH and HuSA in week 6 and 10 of life. Specific antibodies binding KLH in calves were not affected by the maternal dry period length and the secondary antibody responses to $\mathrm{KLH}$ in calves from cows with a 0 -d dry period were even enhanced compared with calves from cows with a 30-d or 60-d dry period, which suggested that calves from cows with a 0 -d dry period had earlier immune maturation and had a faster response to immune challenges than other calves. This study indicated that although omission of the dry period of dairy cows leads to lower IgG in colostrum and lower plasma NAb titers in calves during the first 2 weeks of life, SpAb titers in calves were not affected and even the secondary antibody responses were enhanced, compared with calves from cows with a 30-d or 60-d dry period.

The presence of IgM and IgG NAAb binding glutamate dehydrogenase (GD), carbonic anhydrase (CA), myosin (MYO) and transferrin (TRANS) as representative for antibodies binding autoantigens from calves before drinking colostrum until the first 12 weeks of life in plasma was evaluated (Chapter 6). In addition, NAAb to these four self-antigens were also determined in colostrum and in plasma of their mothers during last 3 weeks before calving. Titers of NAAb to these four self-antigens were already present in the unborn calves, which led to the speculation that NAAb may be already initiated by self-antigens during the fetal phase. Levels of neonatal NAAb during the early weeks of life were positively related with levels of maternal NAAb in colostrum, but the relation was absent after 2 weeks of life. In addition, repeated immunizations with exo-antigens (KLH and HuSA) did not affect NAAb levels in the calves. Before colostrum intake, levels of NAAb in plasma of calves were not related with levels of NAAb in plasma of their mother but were influenced by parity of their mother. Titers of IgM NAAb binding GD and MYO in plasma of calves before colostrum intake were lower in plasma of calves from older cows than younger cows. This study indicated that NAAb are already present in the unborn calf, and levels of neonatal NAAb during the early weeks of life are related with levels of maternal NAAb obtained via colostrum. 
Biological mechanisms behind the effects of shortening or omitting dry period on inflammatory biomarkers, oxidative stress, NAb and NAAb were discussed in Chapter 7. Omitting the dry period affects health variables such as increased levels of positive APP, increased levels of negative APP, reduced levels of bilirubin, increased oxidative stress, increased NAb and NAAb titers in plasma and increased NAb levels in milk. The changes of health variables between cows with different dry period length could not be completely explained by the effects of dry period length on the EB, but also were explained partly by the occurrence of clinical health problems in dairy cows, especially clinical mastitis and uterine health status. Additionally, the consequences of maternal dry period length on immunoglobulin content in colostrum, NAb and SpAb in plasma of calves in the first 12 weeks of life over 2 subsequent lactations were described. Omitting the dry period reduced immunoglobulin content in colostrum and also reduced NAb and $\mathrm{NAAb}$ titers in plasma of calves in the first week of life in both lactations. In both lactations, NAAb but not NAb were already present in the unborn calf. The levels of NAb and NAAb during the early weeks of life were positively related with maternal NAb and NAAb in colostrum, but the relation was absent after 2 weeks after calving. Maternal dry period length did not affect SpAb in calves after immunization.

Omitting the dry period improved EB, metabolic status and fertility. The conclusion of the current study was that omitting the dry period reduced plasma bilirubin level but does not have clear consistent effects on inflammation or oxidative stress compared with a short or a conventional dry period in the first and second lactation after implementation of dry period length treatments. Better liver functionality in cows with a 0-d dry period was associated with improved EB in these cows. Omitting the dry period increased both positive and negative APP, oxidative stress, and resulted in higher NAb in milk compared with a short or a conventional dry period. Effects of dry period length on health variables such as APP, liver functionality markers, oxidative stress markers and NAb depend on many factors, like EB, mammary health, clinical health problems related to inflammation, BCS, and uterine health status. Changes in inflammation variables (increased ceruloplasmin), oxidative stress marker (increased ROM) and higher $\mathrm{NAb}$ in milk were a reflection of the occurrence of health problems related to inflammation. In particular clinical mastitis and reduced uterine health had consequences for the monitored variables related to inflammation, oxidative stress and humoral immune response of cows in early lactation, independent of dry 
period length. Omitting the dry period increased SCC, NAb titers in milk and titers of IgG binding LPS and MYO in plasma compared with conventional dry period. The effects on NAb titers, however, were only present in the first lactation after omitting the dry period and disappeared after repeated omitting the dry period. An increasing titers of NAb in milk for both lactations were associated with increased odds of a high SCC and increased odds of clinical mastitis occurrence. Moreover, an increasing titer of IgG binding LPS in plasma was associated with decreased odds of high SCC and clinical mastitis occurrence. In the first lactation after implementation dry period length and dietary treatments, feeding a glucogenic ration in early lactation increased NAb titers compared with lipogenic diet, which could be partly explained by better EB. In the second lactation after implementation dry period length and dietary treatments, feeding a lipogenic ration in early lactation increased cholesterol levels in plasma compared with a glucogenic ration, which could be explained by high fat content in this ration. Furthermore, albeit omitting the dry period compared with shortening or conventional dry period cows resulted in reduced immunoglobulin content in colostrum and NAb and NAAb levels in plasma of their calves in the first week of life, this did not affect specific immune response and diseases incidence of the calves at least in the first 12 weeks of life. The titers of NAAb in plasma of the calves were not related to NAAb in plasma of their mother before colostrum intake, but in the first week of life there was a relation with NAAb in plasma of the mother, which disappeared again thereafter. This study implies that shortening or omitting the dry period did not negatively affect immune competence of the calves. 

List of abbreviation 


$\begin{array}{ll}\text { APP } & : \text { Acute phase protein } \\ \text { AR (1) } & : \text { First-order autoregressive covariance structure } \\ \text { BCRs } & : \text { B-cell receptors } \\ \text { BCS } & : \text { Body condition score } \\ \text { BHB } & : \text {-hydroxybutyrate } \\ \text { CA } & : \text { Carbonic anhydrase } \\ \text { CHP } & : \text { Clinical health problem } \\ \text { CM } & : \text { Clinical mastitis } \\ \text { CVB } & : \text { Centraal veevoederbureau } \\ \text { DM } & : \text { Dry matter } \\ \text { DMI } & : \text { Dry matter intake } \\ \text { DP } & : \text { Dry period } \\ \text { DPL } & : \text { Dry period length } \\ \text { DVE/ OEB } & : \text { Intestinal digestible protein and degraded protein balance } \\ \text { EB } & : \text { Energy balance } \\ \text { ELISA } & : \text { Enzyme-linked immunosorbent assay } \\ \text { FFA } & : \text { Free fatty acid } \\ \text { FRAP } & : \text { Ferric-reducing antioxidant power } \\ \text { GD } & : \text { Glutamate dehydrogenase } \\ \text { HU } & : \text { Healthy uterine environment } \\ \text { HuSA } & : \text { Human serum albumin } \\ \text { IBR } & : \text { Infectious bovine rhinotracheitis } \\ \text { IgA } & : \text { Immunoglobulin A } \\ \text { IGF-I } & : \text { Insulin-like growth factor-1 } \\ \text { IgG } & : \text { Immunoglobulin G } \\ \text { IgM } & : \text { Immunoglobulin M } \\ \text { IgT } & : \text { Immunoglobulin Total } \\ \text { IL-1 } & : \text { Interleukin 1 } \\ \text { IN-LO } & : \text { Intermediate low liver functionality score } \\ \text { IN-UP } & : \text { Intermediate-high liver functionality score } \\ \text { ISO } & : \text { International standard organization } \\ \text { KLH } & : \text { Keyhole limpet hemocyanin } \\ \text { LFI } & : \text { Liver functionality index } \\ \text { LO } & : \text { Low liver functionality score } \\ \text { LPS } & : \text { Lipopolysaccharide } \\ \text { LSM } & : \text { Least square means } \\ & \end{array}$




\begin{tabular}{|c|c|}
\hline MYO & : Myosin \\
\hline NAAb & : Natural auto antibodies \\
\hline $\mathrm{NAb}$ & : Natural antibodies \\
\hline NEB & : Negative energy balance \\
\hline NLR & : NOD-like receptor \\
\hline NRU & : Non-recovering uterine environment \\
\hline OR & : Odds ratio \\
\hline PMN & : Polymononuclear \\
\hline $\mathrm{PO}$ & : Peroxidase \\
\hline PRRs & : Pathogen-recognition receptors \\
\hline Rho & : Spearman's rank correlation coefficient \\
\hline RIA & : Radioimmunoassay \\
\hline RID & : Radial immunodiffusion assay \\
\hline ROM & : Reactive oxygen metabolites \\
\hline ROS & : Reactive oxygen species \\
\hline RU & : Recovering uterine environment \\
\hline $\mathrm{SCC}$ & : Somatic cell count \\
\hline SEM & : Standard error of the mean \\
\hline $\mathrm{SpAb}$ & : Specific antibodies \\
\hline TAG & : Tri-acyl-glycerides \\
\hline TCRs & : T-cell receptors \\
\hline TLR & : Toll-like receptors \\
\hline TNF- $\alpha$ & : Tumor necrosis factor alpha \\
\hline TRANS & : Transferrin \\
\hline UHS & : Uterine health status \\
\hline UP & : High liver functionality score \\
\hline VDS & : Vaginal Discharge Score \\
\hline VEM & : Dutch net energy evaluation system for dairy cattle \\
\hline VLDL & : Very low density lipoprotein \\
\hline
\end{tabular}



Acknowledgements 
Time brings an end to everything. Finally, my $\mathrm{PhD}$ journey is about to come to an end. The last four years of my PhD journey in Netherlands is one of the most memorable phases in my life. The journey was filled with many good things from scientific growth to self-reflection. Here, I would like to acknowledge people from inside and outside work place, who have contributed and supported to the completion of this $\mathrm{PhD}$ thesis.

First and foremost, I would like to thank Ariette van Knegsel and Henk Parmentier as my supervisors, and Bas Kemp as my promotor. Thank you for the opportunity to pursue my $\mathrm{PhD}$ study at the Adaptation Physiology (ADP) group and being a great team to help me to finish this thesis. Dear Ariette, I am really lucky to have you as my supervisor. Your attention to details was very important during the writing of manuscripts and thesis. Thank you for fruitful discussions and sharing your knowledge especially on scientific writing, presentations, supervision, networking, etc. Ariette, I have very much enjoyed our interaction at the professional and personal levels. Thank you for your patience and encouragement during the four years study. Dear Henk, thank you for your encouragement and care during the four years study. Thank you for sharing your knowledge especially on immunology, Canoco, teaching, supervision, etc. I appreciate how fast you response to every email I sent. Thank you! Dear Bas, you are always there for clarifying and having fruitful discussions with all creative ideas and critical comments to my manuscripts. Bas, thanks for sharing all your good ideas and leading me into the right direction. You have been a great promoter and I really enjoyed the time we worked. Thank you!

I would like to express my gratefulness to all the collaborators for their kindly contribution to the chapters of this thesis. First I would like to thank to the people I worked with in Piacenza, Italy. Erminio Trevisi, thank you very much for the great opportunity to work in your laboratory and learn more about inflammation and oxidative stress. Thank you for sharing your knowledge and giving comments on the chapters. In addition, thank you for your hospitality and help during my stay in Piacenza and I had a great time there. Dear Annarita, thank you so much for sharing your knowledge and skills to work with ILAB 650 equipment and learn some Italian words. Also many thanks to the people in Piacenza that helped me Professor Bertoni, Andrea, Darya, Manuela, Georgia, Francesca and many others that I could not mention one by one. Also, thanks to Bart Ducro for sharing your knowledge about statistics and giving comments on the mammary health paper. Rupert Bruckmaier, thank you for your inputs on my 
article and abstracts for conferences. Danny de Koning thank you for sharing your knowledge about statistics and offering advices on the manuscripts. Gerrit Remmelink, thank you for your quick response to my questions all the time. Juncai Chen, thank you for your inputs and comments for my article about inflammation and metabolism. Ger de Vries Reilingh, thanks for all your contributions, sharing your knowledge to work in the lab and especially to encourage me to be always happy. Thank you! Mike Niewland and Joop Arts thank you for your guidance and help with the lab works. Thank you for the pleasant time and nice conversations during the laboratory works and special thanks to learn me some Dutch.

Many thanks to Nanette van Hapert and Lora van der Kleijn as our secretarial team. Dear Nanette and Lora, thank you for always willing to help me on administrative works and also my personal things. Henry van den Brand, you are my former supervisor during my master study and also the one who offered me to get involved in the WHY DRY project, thank you so much for your support. Wouter Hazeleger, my sincere thanks to you for being my "Dad" during my study for master and $\mathrm{PhD}$ at Zodiac. Thank you for all your support. I also would like to thank to other colleagues of the ADP Group: Nicoline, Liesbeth, Elsbeth, Monique, Rudie, Ilona, Marcel, Bjorge, Jan, Fleur and many others. Thank you for all the supports, togetherness, and fun during my $\mathrm{PhD}$ study.

To "WHY DRY" team: Ariette, Juncai, Renny, Akke, and Wei, many thanks to all of you for great help and support in the past four years. Thank you for the fruitful discussion during our "WHY DRY" meeting. We shared the knowledge and discuss many things related to our "WHY DRY" project. Aside from the meeting, we also did many things for fun together. We have Tea Break, Lunch and Dinner together.

I would like to thank you to DOMO team; Henk, Aart, Jan, Ger, Mike, Joop, Tom, Britt, Mandy, Kristina, Lu, David, Maarten, Michel, and all master students. Thank you for sharing the knowledge about immunology in different kind of animals. We had a lot of fun for our discussion! Also, thanks are extended to (former) people in Animal Health and Immunology discussion group; Britt, Tom, Pierre, and all the members. We got the Education prize for 2017. Hurray!

Sincerely thanks to my students; Fleur Brinke, Eveline Spek, and Xiaoyu Han for their help and excellent work on the experiment. We had a lot of fun working together!

During my $\mathrm{PhD}$, I had a great opportunity to join Wageningen $\mathrm{PhD}$ council (WAPS) for 2 years and also being a chairwoman for WIAS Science Day 2015. I 
would like to thanks to Britt, Carla, Merel, Tetske, Geronda, Renny, Sabine, Nazri, Song, Sanne, Marloes for all the fun during organization. Also for the WIAS Science Day 2015 committee, Henk, Aart, Sofie, Aart, Nirupama, Floor and Mahmoed. I am very happy and proud to have all of you as a great team!

Special thanks is addressed to the "Tropical Room" members (former and present): Ampai, Sofie, Juncai, Danny, Conny, Tom, Carolina, Wei, Lu, Francesca, Baihaqi, and Arda. Thank you for the kindly friendship and provide a nicely environment for working together. I would like to cherish every moment that we had during my PhD study in ADP. I will never forget the joyful that we had during our dinner and drinks outside of the office. Hope our friendship will last even after my graduation.

I would like to express my gratefulness to Ger and Sofie, for being my paranymphs. Dear Ger and Sofie, thank you for your kindness and support for my graduation! I also would like to give my sincere appreciation to Sofie and Ampai for unlimited supports and being there when I need help.

For my (former and present) PhD- and postdoc-mates at ADP: Dr Carol, Anne, Inonge, Nanda, Elske, Caroline, Kristina, Irene, Merel, David, Carla, Pieter, Moniek, Mariska, Renny, Maarten, Anouschka, Michel, Margaretha, Anne, Natasja, Jerine, Roos, and Bahadir, I am happy that I know all of you. Thank you for sharing your knowledge and experience not only about $\mathrm{PhD}$ study but also other things.

For Indonesian $\mathrm{PhD}$ students (former and present) at Zodiac: Mba Vitri, Mas Wiwid, Bang Audrie, Bu Grace, Mba Shinta, Uni Eli, Kang Baihaqi, Kang Edit, Pak Eko, Nuning, Windi, and Titis. We are not that many at Zodiac, but we have a strong bond as a family to discuss many things including our study. Thank you for your support! I also would like to thanks my "Badigers"!! Sentari, Gina, Prima, Shansan, Putri, Windy, Fitri, Ridwan, and Dimas. We have a long-distance friendship during my study, but you guys were always there when I need you. Also to my new family in the Netherlands "Maktab 43" and Kamar C (Mba Intan, Erda and Intan), thank you for all your great support for me.

I would like to thank my other Indonesian friends in Wageningen: Kang Apri \& Teh Yayu, Kang Asep \& Teh Ais, Mba Ery, Dianika, Mba Nuzul, Diah, Yessie, Teh Rani, Mba Wulan \& Mas Irfan, Kang Maman, Teh Pini, Kang Dasep, Kang Dadan \& Teh Nia, Pak Misbah, Pak Erry, Pak Iman, Mba Arita \& Pak 
Agung, Pak Waldi, Pak Taufik, Dian, Mba Uma, Teh Yennie \& Kang Jamal, Gendis, Gumi, Hachi, Farida, Mba Nila \& Mas Anto, Mba Eka \& Kang Yusuf, Emil, Indraningrat, Belinda, Titis, Tika, Pak Diky, Yuda, Pak Fajar, Mba Vivi, Mba Atik, Ahmad \& Tisa, and many others that I could not mention one by one. Thank you for being a big Indonesian family that supports each other in Wageningen! Special thanks to Mba Hikmah, Mba Atin, Mba Nurmi, Mba Nani, and Mba Linda! Thank you for the support, especially in the last period of my $\mathrm{PhD}$ study. Thank you for the cooking class, sharing experiences, and stories!

I would like to thank the academic board of my home university, Universitas Padjadjaran for giving me the opportunity to continue my $\mathrm{PhD}$ study in Wageningen University. I also would like to thank the Directorate General Higher Education, Ministry of National Education of Indonesia for the scholarship of my study in the Netherlands, and the financers of "WHY DRY" project (Dutch Dairy Board, Product Board Animal Feed and CRV) for financing the experiment. In particular, I would like to thank my all senior staff of Faculty of Animal Husbandry, Universitas Padjadjaran, for always supporting me to finish my PhD.

I am so grateful to my beloved mother and father, Tati Heryati and Maryanto, for their endless love, understanding and encouragement for me. Many thanks for always bring my name in each their prayer. Also, I am so grateful to my family especially Ibu Hidayah, Bapak Ibrahim (Alm), Emak, Bapak Aki (Alm), Mbah Kakung, Mbah Putri, brothers and sisters: Asep, Wulan, Vera, Zul, Hilmy and Ipoel. I am so grateful to have you as my family that always support me!

For my beloved husband, Indra Firmansyah, thank you for being there when I found difficulties. With patience and faith, we can solve all the problems together. We know that the journey of PhD life is not easy, but we convert it into a joyful and cheerful moments together. Thanks my imam! 

About the Author 


\section{Curriculum Vitae}

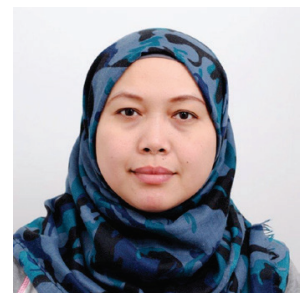

Novi Mayasari (or Novi) was born as the oldest of three in Bandung, West Java-Indonesia, on the 8th of November 1982. In 2004 she completed her bachelor study in Universitas Padjadjaran, Bandung, Indonesia. At this university she focussed on animal feed and nutrition. She has done her experiments for her thesis in both Center for Life Sciences Institute Technology Bandung and Faculty of Animal Husbandry, Universitas Padjadjaran, where she studied fermentation of coffee pulp with Pleoratus ostreatus as feed supplementation to increase production of volatile fatty acid in cattle. Since 2005, she started to work as a research assistant at Laboratory of Animal Physiology and Biochemistry in Universitas Padjadjaran, Bandung. She focused during her research on physiological nutrition in both ruminants and nonruminants. In 2008, she started her Master at the Department of Animal Sciences of Wageningen University with specialisation in Animal Health and Behaviour. For her MSc study she got a scholarship from Directorate of Higher Education Indonesia. She did two major theses in Adaptation Physiology Group and Animal Nutrition Group. Both theses focussed on physiological nutrition and behaviour in broiler chickens. The first thesis was about personality and feed intake in fast and slow broiler chickens. The second thesis was about effect of wet feeding and a high energy to protein ratio on gastrointestinal tract development, performance, and behaviour of broiler chicken under normal and high ambient temperature regimes. After graduated in 2010, she returned to Indonesia and continue working as a researcher and lecturer in Padjadjaran University. In 2012, she got a grant from Directorate of Higher Education Indonesia to start her PhD. In December 2012, she started her PhD at Adaptation Physiology Group in Wageningen University, The Netherlands. Her project is part of the WHYDRY project at Adaptation Physiology Group and within this project she focused on effects of dry period length and dietary energy source on physiological health variables in dairy cows and calves. In 2016, she received a WIAS PhD fellowship to travel to the Università Cattolica del Sacro Cuore, Piacenza, Italy to perform research resulting in two scientific papers which are included in this thesis. In Italy she worked at Faculty of Agriculture, Food and Environmental Sciences under the supervision of professor Erminio Trevisi. Final results of the total $\mathrm{PhD}$ project are included in this thesis. 


\section{Overview of scientific publications}

\section{Peer reviewed scientific publications}

Mayasari, N., G. de Vries Reilingh, M. G. B. Nieuwland, G. J. Remmelink, H. K. Parmentier, B. Kemp, and A. T. M. van Knegsel. 2015. Effect of maternal dry period length on colostrum immunoglobulin content and on natural and specific antibody titers in calves. Journal of Dairy Science 98:3969-3979.

Mayasari, N., W. Rijks, G. de Vries Reilingh, G. J. Remmelink, B. Ducro, B. Kemp, H. K. Parmentier, and A. T. M. Van Knegsel. 2016. The effects of dry period length and dietary energy source on natural antibody titers and mammary health in dairy cows. Preventive Veterinary Medicine 127:1-9.

Mayasari, N., A. Van Knegsel, G. de Vries Reilingh, B. Kemp, and H. Parmentier. 2016. Natural autoantibodies in Bos taurus calves during the first twelve weeks of life. Veterinary Immunology and Immunopathology 178:70-78.

Mayasari, N., J. Chen, A. Ferrari, R. M. Bruckmaier, B. Kemp, H. K. Parmentier, A.T.M. van Knegsel, E. Trevisi. 2017. Effects of dry period length and dietary energy source on inflammatory biomarkers and oxidative stress in dairy cows. Journal of Dairy Science. In press

Mayasari, N., E. Trevisi, A. Ferrari, B. Kemp, B H. K. Parmentier, and A.T.M. van Knegsel. Relationships between inflammatory biomarkers and oxidative stress with uterine health in dairy cows with different dry period lengths. To be submitted

\section{Conference and symposia proceedings}

Mayasari, N., G. de Vries Reilingh, G. J. Remmelink, H. K. Parmentier, B. Kemp, and A. T. M. Van Knegsel. 2014. Effect of maternal dry period and nutrition on colostrum quality, natural and specific humoral immunity, and development of calves. In Book of abstract of WIAS Science Day 2014, 30 April 2014, Wageningen, the Netherlands. 
Mayasari, N., G. de Vries Reilingh, G. J. Remmelink, H. K. Parmentier, B. Kemp, and A. T. M. Van Knegsel. 2015. Long-term effect of shortening dry period of dairy cows on immunoglobulin content in colostrum, natural and specific antibodies and development of calves. In Book of abstract of WIAS Science Day 2015, 5 February 2015, Wageningen, the Netherlands.

Mayasari, N., W. Rijks, G. de Vries Reilingh, G. J. Remmelink, B. Ducro, B. Kemp, H. K. Parmentier, A. T. M. Van Knegsel. 2015. Repeated shortening the dry period, but not the diet, affected natural antibody levels and somatic cell counts in milk of dairy cows. In Proceedings of the $40^{\text {th }}$ Animal Nutrition Forum, 22 May 2015, Merelbeke, Belgium.

Mayasari, N., W. Rijks, G. de Vries Reilingh, G. J. Remmelink, B. Ducro, B. Kemp, H. K. Parmentier, and A. T. M. Van Knegsel. 2015. Effect of dry period length and dietary energy source in dairy cows on natural antibody titers and somatic cell count in milk. In Proceedings of the Joint Annual Meeting 2015 ADSA-ASAS, 12-16 July 2015, Orlando, Florida, USA.

Mayasari, N., W. Rijks, G. de Vries Reilingh, G. J. Remmelink, B. Kemp, H. K. Parmentier, A. T. M. Van Knegsel. 2015. Natural auto antibody in colostrum and calves with a different maternal dry period length. In Proceedings of the $5^{\text {th }}$ European Veterinary Immunology Workshop, 2-4 September 2015, Vienna, Austria.

Mayasari, N., J. Chen, G. De Vries Reilingh, J. J. Gross, R. M. Bruckmaier, B. Kemp, H. K. Parmentier, A.T.M. van Knegsel. 2016. Relationships between metabolism and metabolism in dairy cows with different dry period lengths. In Proceedings of the $15^{\text {th }}$ International Conference on Production Diseases in Farm Animals, 20-23 June 2016, Wageningen, the Netherlands.

Mayasari, N., J. Chen, G. De Vries Reilingh, J. J. Gross, R. M. Bruckmaier, B. Kemp, H. K. Parmentier, A.T.M. van Knegsel. 2017. Relationships between inflammatory biomarkers and oxidative stress with uterine health in dairy cows with different dry period lengths. In Book of abstract of WIAS Science Day 2017, 6 February 2017, Wageningen, the Netherlands. 


\section{Training and Supervision Plan ${ }^{1}$}

\section{The Basic Package (3 ECTS ${ }^{2}$ )}

Ethics and Philosophy in Life Sciences

WIAS Introduction Course

International Conferences (4 ECTS)

ADSA-ASAS Joint Annual Meetings, Orlando, USA

16th International Conference on Production Diseases in farm animals (ICPD), The Netherlands

The 5th European Veterinary Immunology Workshop (EVIW) n Vienna, Austria

\section{Seminars and Workshops (4 ECTS)}

2nd Workshop ; Health and Nutrition in High - Yielding Dairy Cows,

Piacenza, Italy

3rd Workshop ; Health and Nutrition in High -Yielding Dairy Cows, Ludwigshafen, Germany

5th Workshop ; Health and Nutrition in High -Yielding Dairy Cows, Wageningen, The Netherlands

WIAS Seminar ; Development in Ruminant Nutrition; Wageningen

University, The Netherlands

International Symposium on Dairy Cattle Nutrition 2013 "Feed efficiency in dairy cattle" Wageningen University, The Netherlands

International Symposium on Dairy Cattle Nutrition 2014 "Strategies Towards a Quota-Free Dairy Production " Wageningen University, The Netherlands

International Symposium on Dairy Cattle Nutrition 2015 "Dairy cows nutrition and animal health" Wageningen University, The Netherlands WIAS Science Day, Wageningen University, The Netherlands *3

The 40th Animal Nutrition Research Forum, Merelbeke, Belgium

The 41st Animal Nutrition Research Forum, Wageningen, The Netherlands

Wageningen Indonesia Scientific Expose symposium (WISE) 2016,

Wageningen, The Netherlands

Dairy Symposium : Postpartum challenges for the modern high yielding dairy cows, Gent, Belgium.

${ }^{1}$ Completed in the fulfilment of the requirements for the education certificate of the Graduate School WIAS (Wageningen Institute of Animal Science)

${ }^{2}$ One ECTS equals a study load of 28 hours 


\section{Presentations (9 ECTS)}

BASF Workshop : $2^{\text {nd }}$ Health and Nutrition in High-Yielding Dairy Cows,

Oral Presentation, Ludwigshafen, Germany

WIAS Science Day, 2 Poster Presentations, Wageningen, The Netherlands

The $40^{\text {th }}$ Animal nutrition research forum, Oral Presentation, Ghent, Belgium

ADSA-ASAS Joint Annual Meetings, Oral Presentation, Orlando, USA

EVIW, Poster Presentation, Wageningen, The Netherlands

BASF Workshop : $5^{\text {th }}$ Health and Nutrition in High-Yielding Dairy Cows, Oral Presentation, Wageningen, The Netherlands

The $16^{\text {th }}$ ICPD, Oral Presentation, Wageningen, The Netherlands

Seminar of Metabolism in periparturient dairy cows, Oral Presentation, Wageningen, The Netherlands

\section{Disciplinary and Interdisciplinary Courses (7 ECTS)}

Tropical Farming Systems with Livestock, Wageningen, The Netherlands

Fish Immunology Workshop, Wageningen, The Netherlands

Epigenesis and Epigenetics, Wageningen, The Netherlands

Adaptive Animals and Livestock Farming Systems to Meet Global Changes, Rennes, France

Advanced Course Immunology, Utrecht, The Netherlands

\section{Advanced Statistics Courses (3 ECTS)}

Advanced Statistics: Design of Experiments

Statistics for the Life Sciences

PhD students' discussion groups (2 ECTS)

Animal health and immunology discussion group

\section{Professional Skills Support Courses (5 ECTS)}

Information Literacy PhD including Endnote Introduction 2013

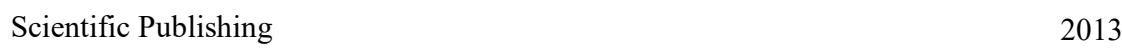

Course Techniques for Scientific Writing 2014

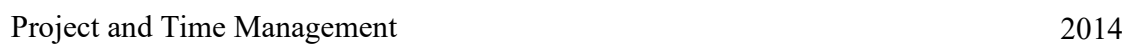

PhD Competence Assessment or Job Assessment 2014

Course Supervising MSc Thesis Work 2015

WIAS course the Final Touch: Writing the General Introduction and 2016

Discussion 


\section{Research Skills Training (8 ECTS)}

Preparing own PhD Research Proposal

2012

External Training Period, Italy, 2 months

Didactic Skills Training (6 ECTS)

Lecture in BSc course Adaptation Physiology

Lecture in BSc course Infections and Disorders

2015-16

Supervision of $3 \mathrm{MSc}$ Thesis Students

Management Skills Training (6.0 ECTS)

Chair WIAS Science Day

Education Committee Member

2016

\section{TOTAL : 57 ECTS}




\section{COLOPHON}

This research described in this thesis was financially supported by the Dutch Dairy Product Board ("Productschap Zuivel", Zoetermeer, the Netherlands), the Product Board Animal Feed (PDV, Zoetermeer, the Netherlands), and Dutch Cooperative Cattle Improvement (CRV, Arnhem, the Netherlands). Novi Mayasari was sponsored by Directorate General of Higher Education, Ministry of National Education, Jakarta, Indonesia.

Cover design

Thesis design and layout

Cover formatting and thesis printed by
: Novi Mayasari and Indra Firmansyah

: Novi Mayasari

: Proefschriftmaken | Uitgeverij

BOXPress 